Historic, archived document

Do not assume content reflects current scientific knowledge, policies, or practices. 



\section{FOREWORD}

To those not familiar with the Bryson Ayres service, it is important to know that our Seed Farms, Nurseries and Modern Warehouses are located just a few miles from our retail stores.

All operations of the Company are under the personal supervision of Bryson Ayres, who is nationally known as one of the most successful plant breeders. Our years of experience and our constant efforts to improve our service have given us an organization second to none. We attribute our remarkable growth to our service and to the great care taken in the growing, selecting and testing of all seeds.

Over one hundred acres are devoted to Hardy Perennial Plants, Roses, Ornamental Shrubs and Fruits, and during the summer months the sight is a beautiful one. Then ton, there are fields of blossoming Red Clover, Sweet Clover, Alfalfa, Alsike, and other grasses, making the farms a source of wonder and delight.

We want you to see and know our Farms and Nurseries, with their flowers and high quality seeds-visitors are always welcome, and an intelligent guide will be furnished gladly. A most cordial invitation to visit us is extended to all.

Sincerely yours,

BRYSON AYRES SEED COMPANY

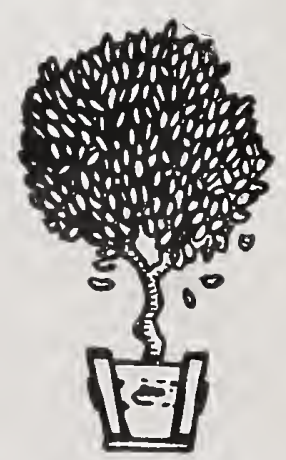

"100 Acres in Flowers" 


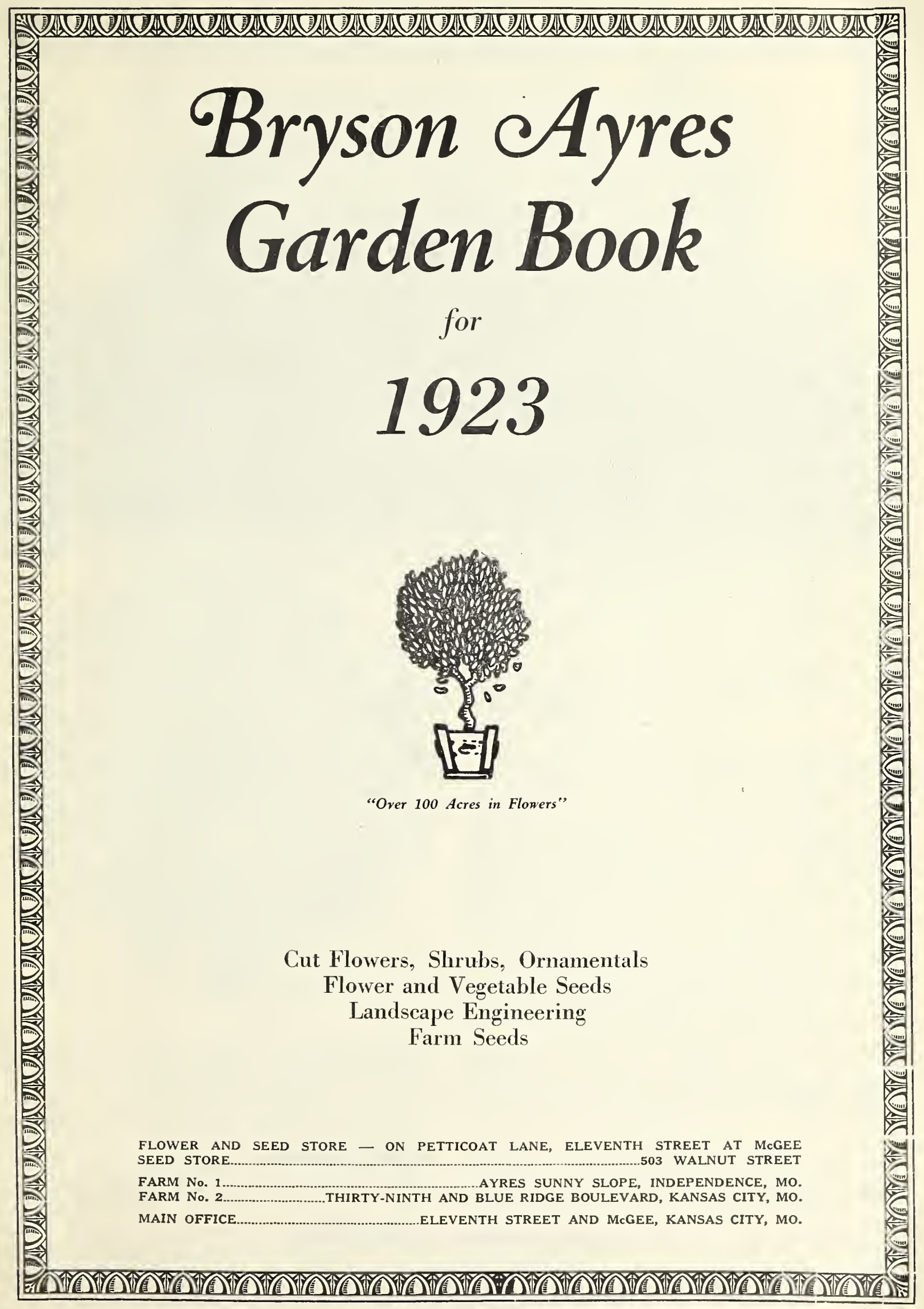




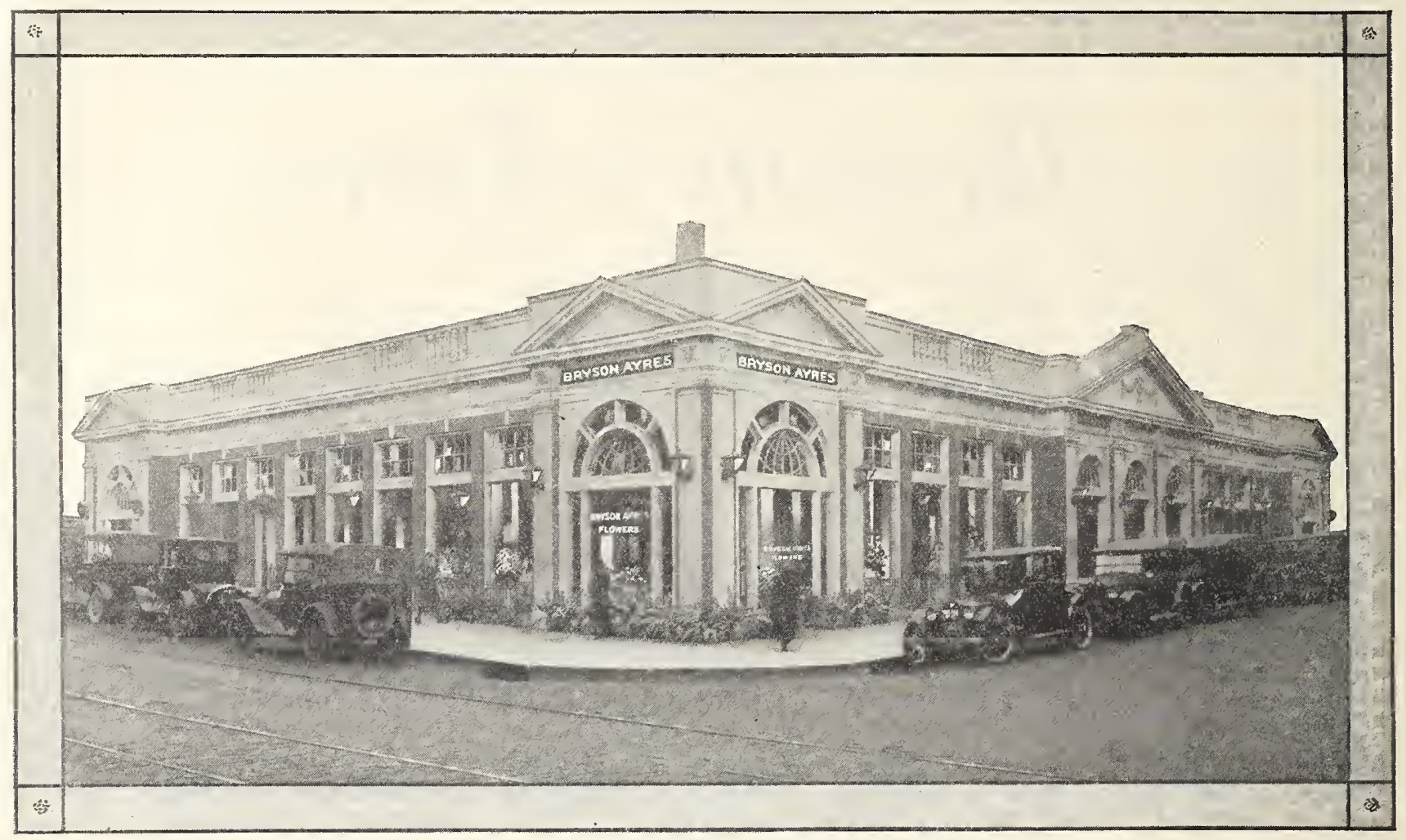

Bryson Ayres New Flower Store, on Petticoat Lane, Eleventh Street at McGee.

\section{ANNOUNCEMENT}

Fr O Fis mentals and both Flower and Vegetable Seeds.

It has long been my ambition to give Kansas City one of the finest and most complete Flower and Seed Stores in America, and it gives me great pleasure to announce to my many friends and customers the opening of the $U_{p}$ town Store. Were it not for the liberal support and confidence given me by my customers and friends, I could not have attained success, and I wish to express to all my most hearty appreciation and thanks.

You are cordially invited to visit the Uptown Store. Your orders will have careful attention and you are assured at all times of Quality and Service.

Sincerely yours,

Phone, VIctor 7591.

BRYSON A AYRES.

(Over One Hundred Acres in Flowers.) 


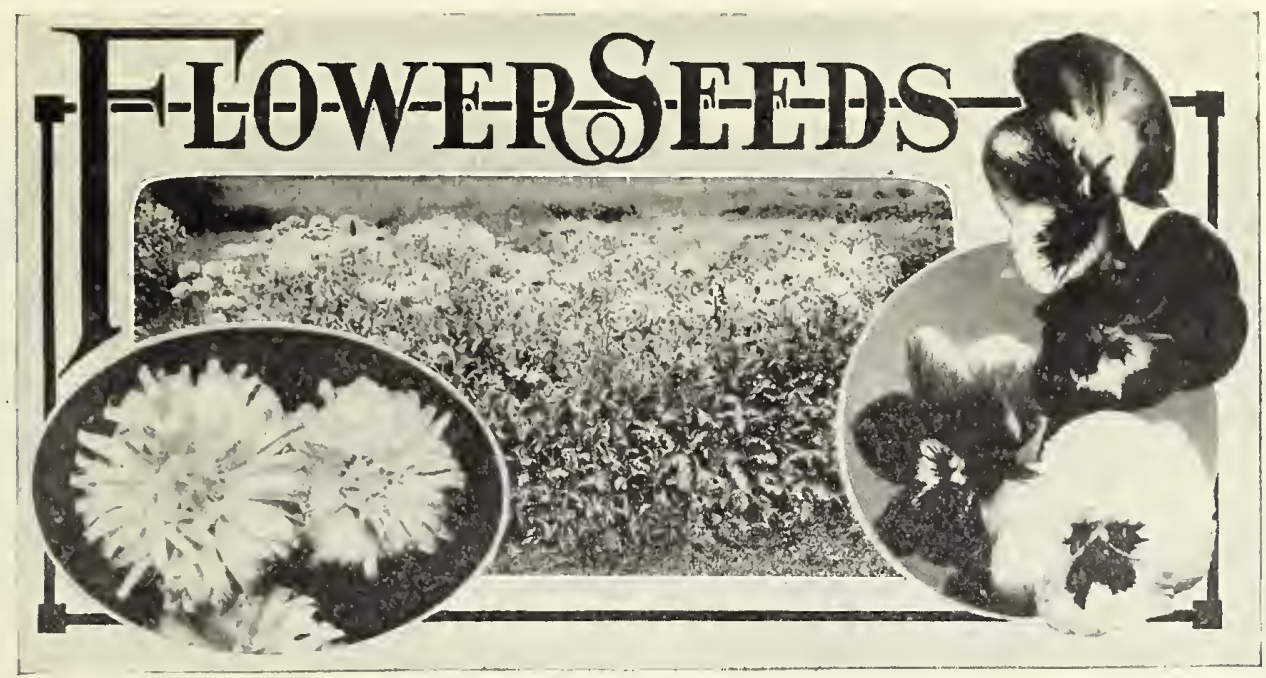

We believe we are the foremost growers of SELECT flower seeds in the United States. Our Sunny Slope farm in Independence, Mo., and our Blue Ridge farm on Blue Ridge boulevard at 39th street in suburban Kansas City, are model flower farms. All operations are under the direct supervision of Bryson Ayres and the greatest care is taken to have all seeds absolutely true to name.

ASTERS.

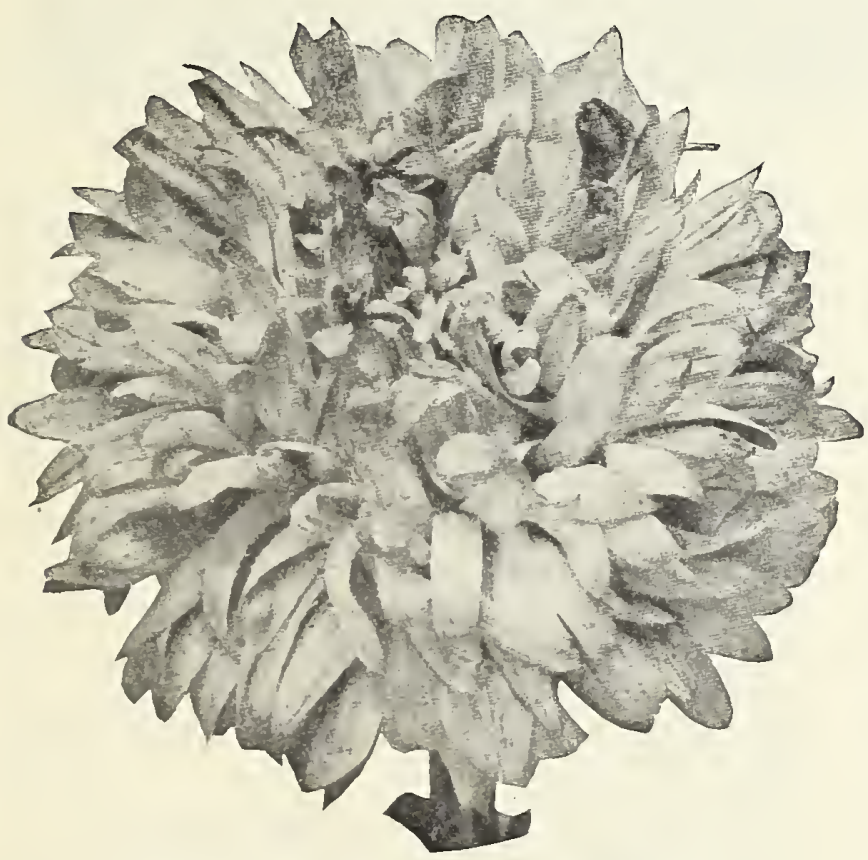

ASTERS, AYRES IMPROVED AMERICAN.

The varieties below are all of American origin, and are the "cream" of the many distinct sorts originated in Amerlca. The lover of asters should have every one of these in his collection. They represent the highest development in asters. Carefully grown from selected seed.

ASTER, Crimson Giant. The plant is vigorous, of upright, branching growth, with strong stems 18 inches long, carrying fine double bright crimson flowers 4 inches in diameter. Grows 24 inches high. Packet, 15e: 1/4 oz., 50c.

Rochester or Mikado. This superb variety is a branching type of the Giant Comet. The double flowers average from $3 \frac{1 / 2}{2}$ to 5 inches in diameter. The color is a charming shade of silvery lavender-pink. Packet, 15c; 1/4 oz., 50e; oz., \$1.5.

White Mikado. The large, pure white flowers measure from 4 to 5 inches across the long petals being artistically curled and twisted. The plants are of branching habit 18 to 24 inches high. Paeket, 15c; $1 / 4$ oz., 50e.
Peerless Pink. A most satisfactory variety for elther kind. bedding or cutting. The plants grnw 24 to 30 inches high, of strong branching growth. The fine double flowers are color is a wonderful and most pleasing shade of rich pink. Packet, 15e; 1/4 oz., 70e.

sensation. The flowers are of a brilliant cardinal shade. The plant is of branching habit, attaining a height measuring 10 inches, and the flowers are borne on stems cates, a "sensation." Packet, 15c; $1 / 4$ oz., 85 c.

Lavender Gem. One of the finest feathery flowers in the beautiful Comet type. The coloring is silvery whtte when first opening, changing to the most delicate shade of lavender when fully expanded. An excellent early bedding variety. Packet. 15e; $1 / 1$ o\%, S5c.

Giant Crego. Mixed parket, 10c.

Dwarf Victoria. Mixed packet, 10c.

Japanese Pompon. First introduced by us in 1914, but owing to the war we were compelled to wait until now to distribute seed. Truly a floral treasure. Finest mixed. lacket, $25 \mathrm{c}$.

ACroliviUM, Heantiful Strawberry. Shades of pink and red. Wonderful dried for winter bouquets. Price, paeket, 15c: large packet, $35 \mathrm{c}$.

ARUILEGIS, Danish Mixed. Similar to Rocky Mountain Hybrids, but much larger and more prolific. price, per picket. 15e; larwe packet, $3 \bar{c}$.

ArYssUM. Sweet Alyssum. Little gem. Most popular bedding variety. Paclict, 10c.

AMARANTHUS, Tricolor Splendens. Per packet, 10e.

ANTIRRIIIJu, Snapdragons. We grow all the leading colors, such as brilliant rose, shell pink, scarlet red, maroon, yellow, white. Separate colors or mixed. Pex packet, 10e; large packet, 25e.

ARCTOTIS GRANDIS, Blue-eyed Afriean Daisy. A very popular daisy which blooms first season from seed.

BALSAM, Finest Mixcd. Paeket, 10e; large packet, 25c.

BAlloon VINe. Annual, climbs. Packet, loe: large packet $25 \mathrm{c}$.

BRACHYCOME, Swan River Daisy. A profusion of blue daisy-like flowers, all summer. Packet, 10c: large packet, 25e.

CALENDULA. Lemon, orange, scarlet, White. Separate colors or mixed. Packets, 10c.

CALliopsis, Anuml Varictics. Mixed. Packet, 10c.

CAMPANUlA, Canterbury Bell. Persicifolia Grandiflora. Fine mixed. Packet, 10c; large paeket, $25 c$.

CANDYTUF, Giant Hyacinth. Flowered. White, Large packet,

Large Flowered. Mixed. Packet, 10c.

OARNATION, Amual Flowering. Mixed. These bloom the first season, and are even more fragrant than our hothouse carnations. 


\section{FLOWER SEEDS---Cont.}

\section{CELOSIA.}

CELosis, Argentea. Beautifully plumed Our mixture contains all the colors of the rainbow. Packet, 10e: large packet, $25 c$.

Hrysonia Chrysantheflora. The greatest floral discovery of the century. Large, compact, chrysanthemum-like flowers in many colors and shades. Annual. Seeds sown outdoors by May 1st. Will bloom from August until frost. Packet, \$2.50. Globosa. Our own creation. Beautiful ball shape, resembling a huge ehrysanthemum. Color, cardinal red, yellow, rose,

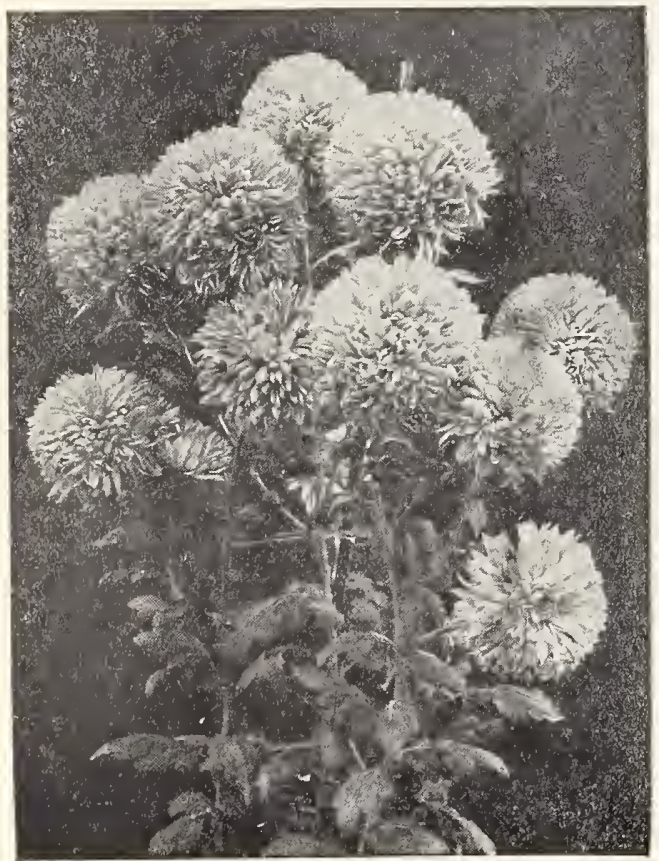

\section{CELOSIAMUM.}

CHRYSANTHEMUM, Annual Summer Variets. New, very fine golden yellow; blooms from early summer until frost. Packet, loc; large packet, 25 c.

CENTAUREa CYANUS, Cornflower. Double bachelor butIn this we have the finest mixtures in existence. It ton. In this we have thith the old single form flowered cannot be compared with the old sing
types. Packet, 10c; large packet, 25 .

CENTAUREA IMPERIALI. Sweet scented. Pink. purple, lavender, white, or mixed. Packet, loc; large packet, 25c.

CHINGSE LANTERn PLANT, Physalis Franchetii. Packet, 10c: large packet, 250 .

CLARKIA, Elegans. Beautiful salmon pink or mixed. Packet, 10c; large packet, 25c.

COROEA SCANDENS. Packet, 10c.

COLUMBINE. See Aquilegia.

COREOPSIS, Lanceolnta Grandiflora. Golden yellow. Packet, 10c; large packet, 25c.

Cosmos, Giant Flowered. Pink, crimson, white or mixed. Packet, 10c; large packet, 25c.

Double and single crested; Sunny slope mixture. We think this grand double and single crested cusmos the greatest and most valuable acquisition to the flower kingdom. The immense double flowers remind one of chrysanthemums, yet they have the delicate texture of the rarest orchid. We are fortunate in having grown a large amount of this seed. Packet, 15e; large packet, 35e.

Lady Lenox. Pink and white. Packet, 10e: large packet, $25 \mathrm{c}$

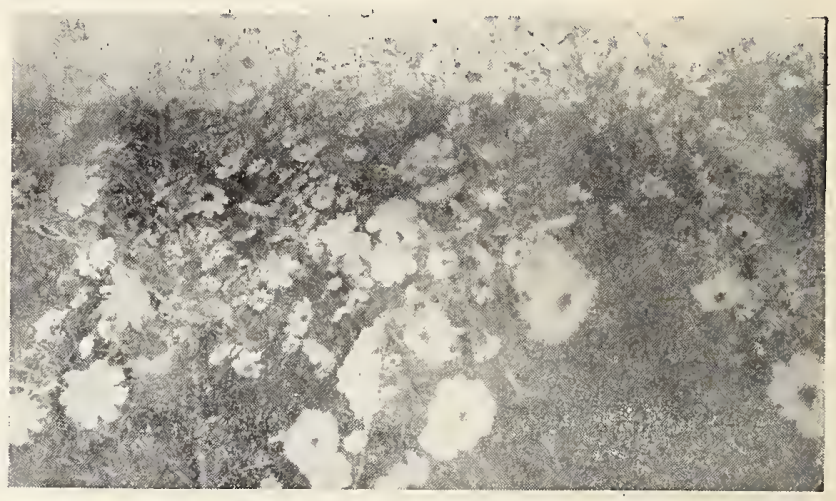

Cosmos

CTPIESS VINA, Cardinal Climber. Annual climber, delicate fern-like foliage and brilliant cardinal flowers. Packet, 15c: large picket, sc.

CUCUMIBLlt VINis. Splendid for trees and fence. Packet, 10e; l:trac packet asc.

DELPIINIUM, Japancs. Packet, 10c; large packet, 25c.

Furuosum. Dark blue with white eye; very popular. Paeket, 10c; large wacket, 25c.

Belladonna. Turquoise blue. Packet, 10c; Iarge packet, 25.c.

DAISY, Shasta. Packet, 10c; large packet, 25e.

DAISY, Double Hellis. English strain. Packet, 10e; larme Packet, 25c.

DIAN'TIUS. Anumal varicties. Good mixture. Packet, 10c. Barbitus. See Sweet William.

GSCH:CHOLTzIA, California Poppy. Golden, orange yellow, rose, white, crimson, cardinal, or finest mixed Packet, 10c; large packet, aśc.

Buslt. See Hunnemania.

WUPHOREIA, Marginita. Everlasting flowers, or straw flowers for winter bouquets. Mixed. Packet, 10c; large Packet, 25e.

Hetcrophylia, Summer Poinsetta. Orange, scarlet, leaves resembling a Poinsetta blossom. Larse Packet, 35c.

FEVEREEW. Packet, 10c.

Forget-Mis-Not, Myosotis. Beautiful blue. Packet, 10e; large packet, $25 \mathrm{c}$.

FOUR-O'CLOCK. Packet, 10c.

GAILI.ARDIA. Packet 10c; large packet, 25c.

Geranium. Packet, a丂c.

Godetia. Good mixed, Paeket, 10e.

Gomphrena (Globe Bachelor's Button). Packet, 10e: larse packet, zృc.

GoURos, Omamental. Ayres' American and European mixed. Very fine. Packet, 10c; large packet, 25c.

GRASSES, Ormamental. Annual varieties; mixed. Contains the cream of the annual grasses throughout the world. Fine dried for winter bouquets. Packet, 10c: large packet, 25c.

GYPSOPHILA (Baby's Breath). Fine with bouquets, especially Sweet Peas. Packet, 10c: large packet, gse.

Paniculata (Perennial). Large packet, ə5c.

HeLIANTHUS. See Sun Flower.

HELICHRYSUM, Original Stravflower. Everyone should grow some of these beautiful flowers to dry for winter grow some of these beautiful flowers to dry for winter tel shades are included in this mixture, as well as the most vivid shades of red, rose, and yellow. Packet, 15c; most vivid shades

HELIOTROPE. Giant Hybrids, Mixed. Packet, 10c: large packet, 25c.

HOLIYHOCK. Double. Light pink, maroon, rose scarlet, yellow, white, crimson. Fine mixture, Packet, 10c: large packet $25 c$. 


\section{CELOSIA BRYSONIA CHRYSANTHEFLORA AN "EVERLASTING" BLOOM NEW TO THE FLOWER WORLD.}

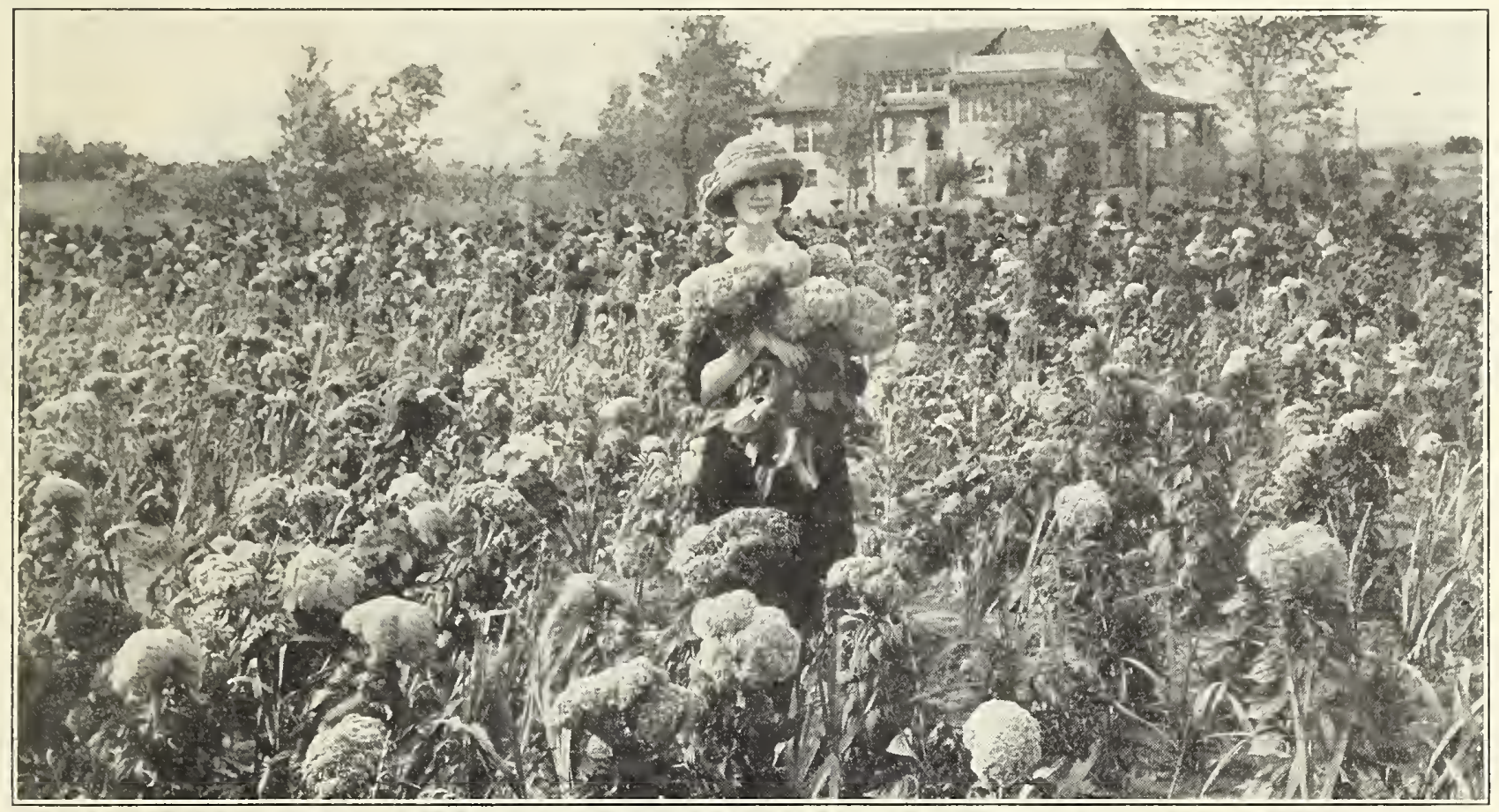

ONE OF THE BRYSON AYRES CELOSIA FIELDS.

Fifteen years ago Bryson Ayres began developing an autumn flower of unusual size and variety of color. He crossed the old-fashioned coxcomb, a single flower in a warm shade of red, with Celosia Argentea, a plume-like flower in various colors. Twelve years of experimenting with as many generations of the crossed varieties were necessary before he developed the two varieties, Celosia Brysonia Chrysanthef'lora and Celosia Brysonia Compacta, which have, in the last three years, won for him a unique place among the horticulturists of America.

The flowers are distinguished not alone for their size-they grow in height from two to six feet, and the blossoms are sometimes eighteen inches in width-but because they are "everlasting," retaining all their beauty of color, size and shape after being properly dried in a dry, dark place. They have an immense ornamental and decorative value, and are being ordered in car load lots by Marshall Field \& Co., of Chicago, and many other large mercantile estab. lishments, for special decorative purposes.

\section{CULTURAL DIRECTIONS.}

Celosia Brysonia Clirssantheflora Easy to Grow.

Almost any soil will grow Celosia Brysonia Chrysantleflora. Sow out of doors during April and May, either broadcast or in rows and give seed a shallow covering (about $1 / 4$ inch) of pulverized soil. If extra large flowers are desired it is best to thin them out to about six inches apart. However, many prefer to grow them about two inches apart, which makes smaller flowers.

Nothing can equal CELOSIA BRYSONIA CHRYSANTHEFLORA as a home, yard or garden decoration. They are in bloom throughout the summer and fall and the gorgeous colors are a source of wonder and delight to everygoous.

"Drying of Celosia Rrysonia Chrysantheflora."

The drying of the flowers is very simple. Hang them upside down in a dark cool place and they will dry and retain their beauty and color indefinitely. Everyone who has seen CELOSIA BRYSONIA CHRYSANTHEFLORA dried commends its usefulness very highly. It is beautiful in bouquets the year around.
Celosia Irysonia Chrysantheflora Seed.

Mixed Colors. Old Rose, Salmon, Golden Wisteria, Shell Pink, Deep Red, Violet, Mulberry, Yellow, Lemon, Nile Green and Crimson.

Retail packet-Small size ..............\$0.50 each Retail packet-Medium size ...............2.00 each Retail packet-Large size ..................... each

\section{Ball Celosia seed}

Grows 18 inches tall. Forms bushes covered with balllike flowers. Fine for bedding and cut flowers. Blooms continuously throughout summer and fall. Colors, Red, Pink, Yellow, Old Rose.

Packets, mixed colors...

\$0.35 each

Packets separate colors

\section{Extracts Pertaining to Celosia Brysonia Chrysantheflora Taken from Some of the Leading Newspapers of the World.}

Celosia Brysonia Chrysantheflora, Recently developed by Bryson Ayres, of Kansas City, Mo. In addition to its particular adaptability for use in Iarge decoration Celosia Brysonia Chrysantheflora has another quality that appeals to Florists. Its ability to be shipped long distances without the Flower head being marred. Still more important is the fact that this Celosia may be dried easily and any stock which has not been sold while fresh may be hung up in a cool, dry place and so preserved for sale later.-From the Horticultural Trade Journal, London, England.

The wonderful creation Celosia Brysonia Chrysantheflora is now on display in Chicago. It is the origination of Bryson Ayres and is being shown by him in many cities.-From the Chicago Daily News.

Bryson Ayres is shipping several car-loads of Celosia Brysonia Chrysantheflora to the Eastern markets where they are being used extensively in the large stores of New York and Chicago. One of the principal characteristics of this flower is its ability to be shipped long distances without the flowers being marred and the fact that the flowers may be dried easily and retain their beautiful colors indefinitely. -From the Kansas City Star.

The famous Celosia Brysonia Chrysantheflora oniginated with S. Bryson Ayres of Kansas City. It seems to be the flower of the day as it is becoming popular both in America and Europe.-From the Detroit Free Press. 


\section{FLOWER SEEDS---Cont.}

HYACINTII REAN (Dolichos). Annual climber. Packet, 10c; large packet, $25 \mathrm{c}$.

Kochra. Fine strain. Facket, 10c.

LARIKSPUR. Sunny Slope Giants. Pink, white, red, blue purple, lavender, cardinal, rose, carmine, lilac. Separate colors or mixed; the finest in existence. Packet, 25e. Fine mixed. Packet, 10c.

GATHYRUS LATIFOLIUS (Perennial pea). Mixed. Packet, 10e; large packet. 25e.

minaria marocciana. Packet 10c.

GINUI. Packet, 10c.

LoBelia. Finest mixture. Packet, 10c; large packet, 25e.

LUPINUS. Annual Lupinus. We have imported seed of this valuable annual from nearly every part of Europe. We also have some wonderful American hybrids; these have been grown very successfully at our Sunny Slope Farm.

HUNNEMA NNIA FUMARIA EFOLIA. Called by some Tulip Poppy; very beautiful. Packet, loc; larise packet, 25c. Packet, 25c.

\section{MARIGOLD.}

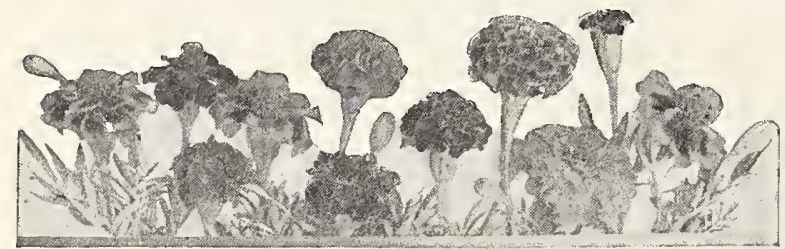

MARIGOLD. Tall African mixed. One of Bryson Ayres' specialties. We have obtained wonderful results in this beautiful old fashioned flowers. Packet, 10c; larse packet. Separate colors in lemon or orange. Packet, 25e.

French Dwarf. Double flowered mixed. Packet, 10e large packet, 25 c.

MIGNONETTE. No garlen should be without sweet mignonette, the flower of Shakespearean days. Packet, 10c; large packet, 2 sc.

MORNING GLORY. American or Japanese. The colors in a fairy mixture. Packet 10c; large packet, 25e.

NASTURTIUM. Dwarf. Our finest mixtures. Paeket, 10e; ounce zoe.

Tall. Extra fine mixed. Packet, 10c; ounce, 20c.

NICOTIANA AFFINIS (Alata Grandiflora), Blooms at night; very sweet scented. Packet, 10c.

NiGELIA (Love-in-the-Mist). Packet, 10 .

PANSY. Giant Sunny Slope Mixture; grown on our own farms. This mixture contains the cream of the whole world. No better seed can be obtained from any source. they remind one of huge orchids. Packet, 2ac: oz., \$7.00. Fine Mixed. Packet, 10c; large packet, 25e.

PETUNIA. Large flowered. Fringed and Double. Mixed. Packet, 35e.

Finc hybrids. Mixed. Packet, 10c; Iarge packet, 25c.

PIILOX DRUMmondi. Fine Mixed. Paeket, 10e; large packet, äe.
PHYSALIS Fra NCHETI (Chinese Lantern Plant). This beautiful plant came to us from France. It is, perhaps, the most ornamental of all our ornamental flowers. The beautiful pods can be dried, and make most beautiful winter bouquets. Packet, 35c.

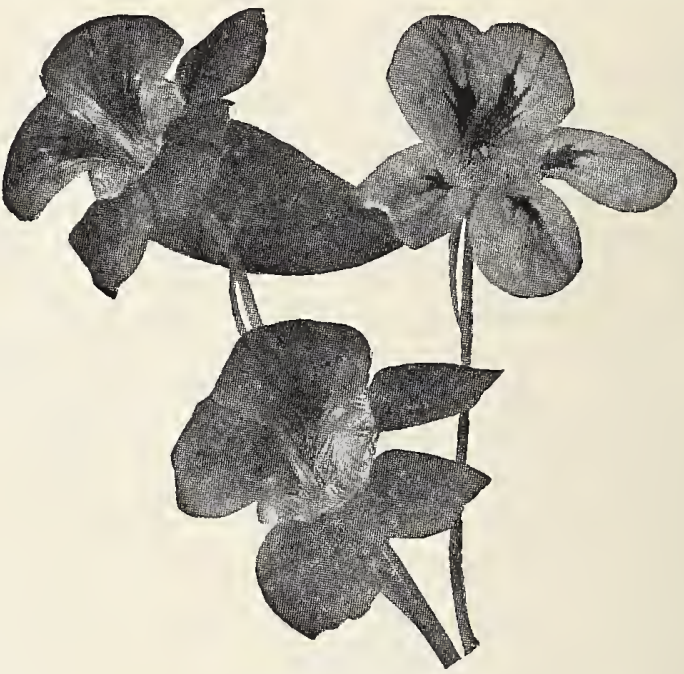

NASTURTIUM

POPPIES. Annual. Mixed. Containing the cream of the Shirley, Mikado. Carnation-flowered and Peonie-flowris Packet, 10c; large packet, 25e.

Annual Newport Pink. We obtained this seed from the originator. This beautiful poppy resembles a huge chrysanthemum, and is most useful as a cut flower. Packet, 25c. oricntal, Perennial. Fine mixed, including orange red, maroon and pink. Packet, 25e.

portulaca, Fine mixed. Packet, 10c.

SALPIGLossis. Beautiful orchid-like flowers. Produces from early summer until fall. One of the best annuals. Packet, 10c; large packet, 25c.

STOCKS. English and German mixed. Packet, 10c; Iarge Packer, 2sc.

S'TIR AVIOLOWERS. Mixed or separate colors. Wonderful for winter bouquets. Packet, 15e: large packet 35c.

SUN FLOWER. Giant mixed, including red, yellow, cream. Packet, 10e.

SWLET WILLIA (Dianthus Barbatus). Mixed. Packet, 10c: larae packet, 25c.

VGRBENA. Pink, white, purple, Scarlet, rose; separate colors or mixed. Packet, 10c; large packet, 25e; oz., \$2.00.

WALLFLOWER. This grand English flower should be more generally grown. Fine mixtule. Facket, I0c; large packet, 25e.

\section{BRYSON AYRES ZINNIAS.}

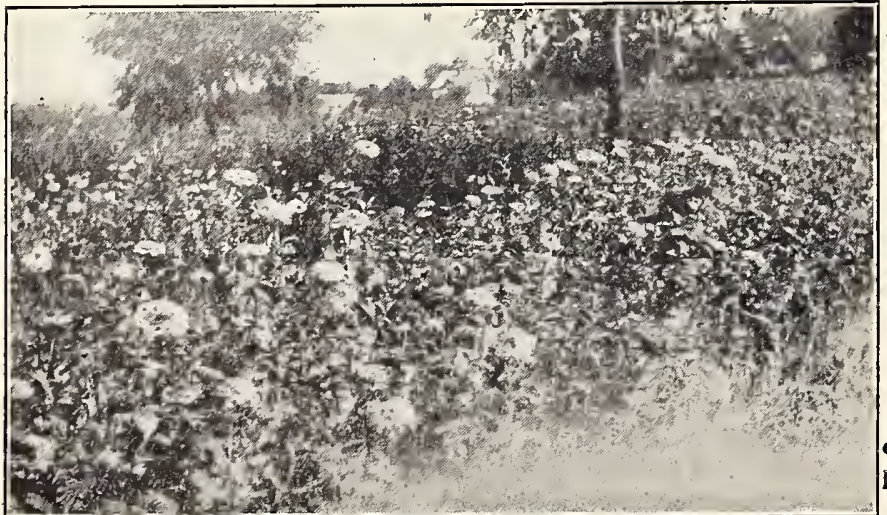

OVER ove huNDEED DIFHERENT COLORS OF ZINNIAS ARE GIROWN ON OUR SEED FARMS.

WE ARE AMERICA'S FORLUOST ZINNIA GROWEIRS.

IINNIA. Ayres, Mammoth. We feel that our Giant strain is the finest in existence. Scarlet, white, crimson, purple, yellow gold en primrose, salmon. Separate colors. Packet, Fine mixed. parket 10c; large packet $25 \mathrm{c}$.

Dahlia Flowered. Curled and crested. This grand novelty should be in every garden. Packet, 15c; large packet, 25e. Dwarf. (Little Red Riding Hood). Beautibul orange red. Packet, 10c: la rge packet, 25c.

Ayres new collection of Giant Zinnias, six packets, one each of Red, Orange, Yellow, Purple, White and Pink. Entire collection, value $\$ 1.50$ for only $\$ 1.00$.

On Our Sunny Slope Farm. A YRES' Mammoth Zinnias. 


\section{BRYSON AYRES SPENCER-BUTTERFLY SWEET PEAS}

We are now recognized among the foremost authorities on Sweet Peas in the world. From the beginning, with a few rows of Sweet Peas, twenty years ago, Bryson Ayres has seen this humble start develop into one of the largest industries of its kind. Some of the world's choicest varieties are of the Bryson Ayres origination. We especially desire that you visit Sunny Slope during the late winter months and see Sweet Pea vines in our conservatories, $16 \mathrm{feet}$ high, literally covered with orchid-like flowers, so sweet, so fragrant that one is thoroughly convinced that there is a "Sweet Pea Fairyland."

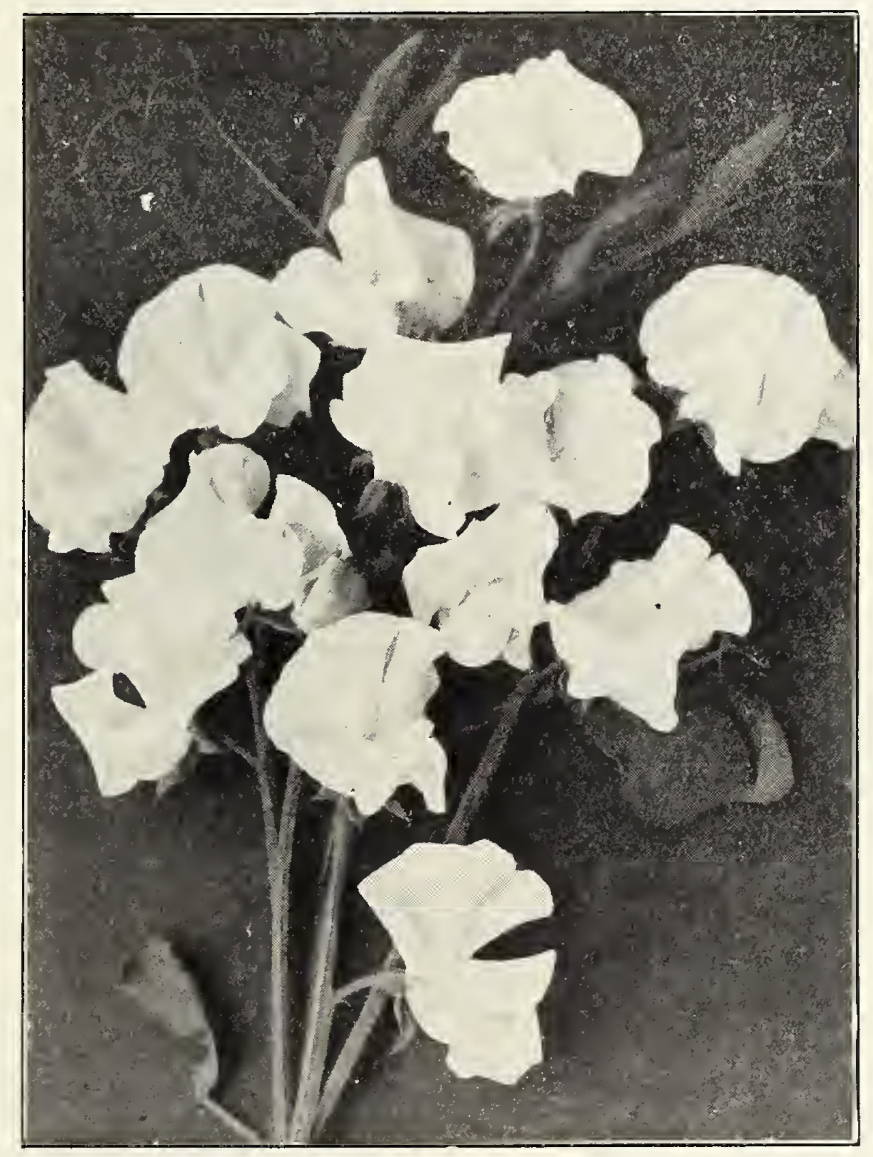

\section{AYRES BUTTERFLY-SPENCER SWEET PEAS \\ WE OFFER RE-SELECTED STOCKS FROM OUR SUNNY SLOPE FARMS}

\section{AYRES SPECIAL MIXTURE.}

AYRES SPENCER-BUTTERFLY MIXED. A mixture of all the summer flowering varieties listed herewith with additional 1923 novelties, the finest mixture; $1 / 2$ oz., 30c; oz. 50c; $1 / 4$ lb., \$1.50; $1 \mathrm{~b}$., \$5.00.

$$
\text { WIIITE }
$$

KING WVHTE. The finest white; 1/2 oz., 25c; oz., 40c., 1/1 lb., $\$ 1.20$ : 1 b., \$4.00.

OONSTANCE HINTON. Black-seeded; 1/2 oz., 25e; oz., 40c; $1 / 4$ 1b., \$1.20; 1b., \$4.00.

CREAM

FLORADALE FAIRY. Rich cream, duplex; 1/2 oz., 25c; ox. 40c; $1 / 4$ lb., $\$ 1.20 ; 1 b ., \$ 4.00$.
ISAlBEL, MALCOLM. Black-seeded; $1 / 2$ oz., 25c; oz., 40e; $1 / 4$ 1b.. \$1.20: 1 b., \$4.00.

QUEAV VICTORIA SPENCER (BURPEE). Deep primrose, F'lushed rose; o\%, $40 c$ : $\% / 4$ 1b., $\$ 1.20 ; 1 b ., \$ A .00$.

\section{BI,USH}

ELEGANCE. Blush-pink of largest size; $1 / 2$ oz., 55e; oz. $\$ 1.00 ; 1 / 4$ 1b., \$3.00; 1b., \$9.00.

AGRICOLA. White, flushed lilac; ox., 40e; $1 / 41 b ., \$ 1.20$ 1b., \$1.00.

VALENTIN L. Light shell-pink; 1/2 ox., 35c; oz., 60c; 1/4 lb., $\$ 1.75$ : $1 \mathrm{~b} ., \$ 6.00$.

CHARM RIUSH. Shaded lilac; oz., 40c; $1 / 4$ lb., $\$ 1.20 ; 1 b ., \$ 1.00$. 


\section{BRYSON AYRES SWEET PEAS-.-Cont.}

\section{LIGHT PINIK}

CARESS. Soft pink on cream. 1/2 oz., \$1.00; oz., \$1.50.

DAISYHUD. An improved Elfrida Pearson; 1/2 oz., 55e; oz., $\$ 1.00 ; 1 / 4$ 1b., $\$ 3.00 ; 1 b . \$ 9.00$.

EIFIRID A PEARSON. Deep blush-pink; 1/2 oz, 25c: oz., 40c; $1 / 4$ 1b., \$1.20; $1 \mathrm{b.}, \$ 4.00$.

MAVIS. Deep pink on white ground; 1/2 oz., 30c; oz., 50c; 1/4 $16 ., \$ 1.50 ; 16 ., \$ 5.00$ CIS WRIGIIT. Pink on cream; oz., 40r: 1/4 1b., \$1.20; $1 \mathrm{b.g}$
$\$ 4.00$.

\section{CREAIT-PINT}

HIRIDESMAID. Rich salmon-pink on ivory-cream ground Packages only. Retail price, z5e each.

MARGA RET ATIEE. Deep pink on cream, suffused salmon; oz., 40c: $1 / 4$ lb., \$1.20; 1 b., \$1.00.

MIRS. HUGH DICKSON. Apricot-pink on cream; oz., 40e; $1 / 41 b ., \$ 1.20 ; 1 b ., \$ 1.00$.

MIS. ROUTzaHN. Buff suffused delicate pink; oz,, 40e; $1 / 41 \mathrm{~b} ., \$ 1.20 ; 1 \mathrm{~b} ., \$ 4.00$.

W. T. IUTCIINS. Creamy apricot-pink; oz., 40e; 1/4 1b., $\$ 1.20 ; 16 ., \$ 4.00$.

\section{SALMON-PINIS}

BERYL. Rich, soft salmon-pink, shaded buff; $1 / 2$ oz., 25e; oz., 40c; $1 / 4$ 1lb., $\$ 1.20$ : 1b., \$4.00.

Doris USHER. Salmon-pink on cream; oz., 40e; $1 / 41 \mathrm{~b}$. $\$ 1.20 ; 1 \mathrm{~b} . \$ 4.00$.

LILLIAN. Pale salmon-pink, suffused amber; oz., 40c; 1/4 $1 \mathrm{~b} ., \$ 1.20 ; 1 \mathrm{~b} ., \$ 4.00$.

PICTURE. Bright pink, flushed cream. Packets only. IRetail price, 25e each; $1 / 2$ oz., \$1.25.

\section{DEET PINK}

ANNIE BOWNAss, Bright pink, heavily suffuser salmon on white ground; oz., 40c: $1 / 1$ lb., $\$ 1.20 ; 1$ b., $\$ \frac{4}{4.00}$

COUNTESS SPENCER. Soft rose-pink; oz., 40c; 1/4 1b., \$1.20; $1 \mathrm{b.}, \$ 4.00$.

HAWLMATK PINIx. Standard bright salmon-pink; wings rose-pink; 1/2 oz., 40e; oz., 75e; $1 / 4$ lb., \$2.50.

\section{ROSE}

HERCULES. Rich pink, of magnificent size and form; oz., $40 c$ : $1 / 41 \mathrm{~b}$., $\$ 1.20 ; 1 \mathrm{~b}$., $\$ 4.00$.

DECORATOR. Rose overlaid with terra-cotta; oz., 40c $1 / 4$ lb., $\$ 1.20 ; 1 \mathrm{~b} ., \$ 1.00$.

GEORGE HERBERT, Bright rosy carmine: oz., 40e; 1/4 1 b., $\$ 1.20 ; 1 \mathrm{b.}, \$ 4.00$.

ROSABELLE. Large rose self with white blotch at base; oz., 40c: $1 / 4$ 1b., \$1.20; 1 b., \$1.00.

\section{SCARLET}

MRS. C. P. TOMLIN. Rich, fiery scarlet; sunproof. Packets. Retail price, 25e each; 1/2 oz., 35e; oz., 60e; 1/4 lb., \$1.75; 1b., \$6.00.

VERMILLION BRILLIAN'. Intense scarlet self; oz., 40c; $1 / 4 \quad 1 \mathrm{~b} ., \$ 1.20 ; 1 \mathrm{b.}, \$ 4.00$.

\section{LAVENDER}

DON ALVAR. Soft silvery blue; oz., 40e; $1 / 4$ 1b., \$1.20: 1b., $\$ 1,00$

HAWLMARK LAVENDER. True, clear light lavender: 1/2 oz., \$1.75; Oz., \$2.00.

FLORENCE NIGHTINGAIE. Clear lavender with rose-pink sheen; oz., 40c; $1 / 4$ ll)., \$1.20; ll)., \$4.00.

MARGARET MADISON. Azure-blue self; oz., 40e; $1 / 4$ 1b., $\$ 1.20 ; 1 \mathrm{b.,} \$ 4.00$.

ORCIID. Deep lavender, sufîused pink; 1/2 oz., 25e; oz., $40 c ; 1 / 411) . \$ 1.20 ; 1 b ., \$ 4.00$.

R. F. FELTON, Lavender, suffused mauve; oz., 40e; 1/4 lb., $\$ 1.20 ; 1 \mathrm{~b} ., \$ 4.00$.

\section{HLUE}

MRS. TOM JoNES. " Eright Delphinium-blue; 1/2 oz., 5se; oz., \$1.00; $1 / 4$ 1b., \$3.60.

PHAN'TOM BLUE. A pastel shade of blue; oz., 40c; $1 / 41 \mathrm{~b} .$, $\$ 1.20 ; 16.84 .00$.

IVEDGWoit. Deep azure-blue; oz., 55e; 1/4 1b., \$1.75; 1b., \$ับ. 85.

\section{DARK BI,UE}

BLUE MONARCH. Extra large, dark blue self; oz., 40e; 1/4 11)., \$1.20; 1b., \$4.00.

\section{CULTURAL DIRECTIONS-SWEET PEA GROWING A PLEASURE}

It is easy to grow Sweet Peas and almost any soil will grow them. Spade the ground deep, then add to soil, if convenient, commercial fertilizer (such as pulverized sheep manure) or the well rotted product of the barn yard. Mix well with soil, being careful to pulverize all clods. Dig trench from 4 to 6 inches deep and sow seeds thickly, covering them with about 1 inch of soil. For a row 50 feet long. use 1/4 pound of seed. After plants are about an inch high, begin to cultivate and support with string, wire netting or brush, or, if planted along a woven wire fence, no support is needed. When in blossom, pick the flowers daily, as this prolongs the blooming season.
THE LADY EVELINE. Beautiful rosy mauve: oz., 40e; $1 / 4$

\section{PUR PIE}

OYA. PURPLE. Rich, warm purple; oz., 40c; 1/4 1b., \$1.20; R'THUR GIREEN. Claret colored self; oz., 40c: 1/1 1b., \$1.20 1b., \$4.00.

ROSLIND. Rose-crimson
Packets, 25e; 1/2 oz. \$1.50.

IAARARA. Large salmon-orange self; 1/2 oz., 25e; oz., 40c; $1 / 4$ lb., \$1.25; 1b., \$4.50.

TIRIING S'TENT. Deep salmoll, suffused orange; or.., 40c: OR.ANGE

HELEN LEWIS. Standard crimson-orange; wings orange-

BERT SYDENHAM. Glowing orange self; $1 / 2$ oz., 35e; oz.. 1b., \$1.75; 1 b., $\$ 5.00$.

A NGERINE. New, deep orange; 1/2 oz., 40c; 0z., 75c; 1/4 1b.,

THE PRESIDENT. Dazzling orange-scarlet: oz., 50c: 1/4 1b., \$1.25; $1 \mathrm{b.,} \$ 5.00$.

THOMAS STEVENSON, MPROVED. Standard orange; s6.00.

\section{CERISE}

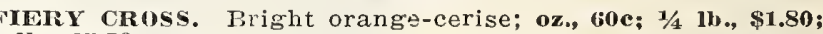

$11 \%, \$ 1.50 ; 16 ., \$ 5.00$.

ILLUMINATOR. Rich, cerise-salmon; oz, 25e: 1/4 1b., \$1.80; 1)., \$4.00.

INCERITY. Cerise self: largest size; oz., 40c; 1/4 1b., \$1.20; EING EDVIRD. Deep carmine-crimson; oz., 40c; 1/4 1b., $\$ 1.20 ; 16 ., \$ 4.00$.

HAWLMARI MAROON. Like polished mahogany: 1/2 oz., $\$ 1.75 ; 0 \% ., \$ 3.00$.

IKING MANOEL. Deep chocolate-maroon; 1/2 oz., 50c; oz. 1W., \$2.80; $10 ., \$ \$ 9.50$.

1/1b., \$1.20; 1 b., \$1.00.

\section{ART SHADES}

BROCADE. Satiny salmon, lavender and rose-pink: $1 / 2$ oz., oz., 60e; $1 / 4$ lb., \$1.75; $1 \mathrm{~b} ., \$ 5.50$.

CARLES FOSTER. Hydrangea pastel shades; oz., 40c: $1 / 4$

$1 \mathrm{b.}, \$ 4.00$.

PIRINCE GEORGE. Pastel rosy lilac; oz., 40e; 1/4 1b., \$1.20; lb., \$4.00.

ROSINA. Rich rosy heliotrope; oz., 40c; 1/4 1b., \$1.20; 1b., $\$ 1.00$.

NSTA NE ACOMB. Creamy white, suffused mauve; oz.,

\section{PICOTEE}

CHERUR. Rich cream, edged with bright rose; oz., 40e;

IN'TY. Pure white, edged with rose-pink: oz., 40c; 1/4 lb.,

$\$ 1.20 ; 13 ., \$ 1.00$.

IIRS. A. G. GENTLE. White, edged scarlet; oz., 40c; $1 / 4$ 1b.,

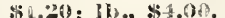

MIBS. TOVVNSEND. White with picotee edge of blue: ox.. 40e; $1 / 4$ lib., $\$ 1.20 ;$ ib., \$4.00.

IRS. FRED KIMl. T. White with narrow edge of violetblue; oz., doc: $1 / 4$ li., $\$ 1.20 ; 1 b ., \$ 4.00$. lose; oz., 40c; 1/4 lb., \$1.20; 1b., \$4.00. $1 / 4$ lb., $\$ 1.20 ; 1 b ., \$ 4.00$.

$1 / 4$ lb., $\$ 1.20$; lb., $\$ 4.00$. 


\section{SUMMER BULBS}

The Florist, as well as the Landscape Gardener, will find much of interest in the following lists. Ayres' Bulbs are selected with the same care and attention to Quality as are Ayres' Seeds. All of the bulbs and roots offered herein are first size (unless otherwise stated), sound and healthy, and sure to bloom if given reasonable car'e.

We take particular pains in speciaily packing bulbs and roots to ensure their arrival in good condition and, for this reason, always ship bulbs separately from seeds when both are ordered. When placing your order, specify when and how you wish your bulbs to be sent.

Our collection of Dahlias is especially worthy of attention. Our lists of bulbs are not so extensive but are carefully selected and comprise the best varieties for all purposes; in fact, it has been our aim throughout to offer Quality rather than Quantity.

Note-Three or more bulbs will be supplied at the dozen rates, 25 or more at the 100 rates, and 250 or more at the thousand rates.

AIARYLLIS. Sprekelia formosissint. Ac cach; doz. \$3.00. Iippenstrum Johnsoni. 75e each; 3 for $\$ 1.90$.

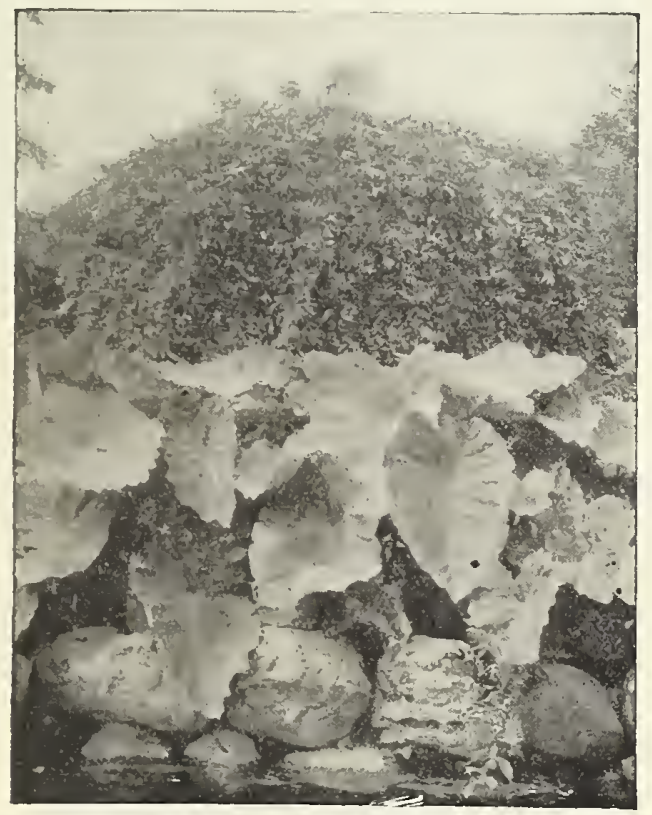

CAIADIUM

CALADIUM Esculentum Elephant's Ear (Colocasia); 9 to 11 inches; $30 \mathrm{c}$ each: 6 for $\$ 1.35$.

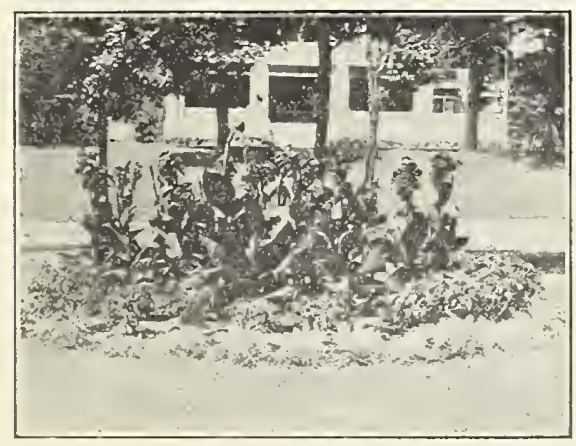

CANNAS

CANIAS, The Fincst Five-

Fiery Cross; $40 \mathrm{c}$ each; doz., \$3.50; per $100, \$ 23.00$. City of Portland; $30 \mathrm{c}$ each: doz., $\$ 2.75 ;$ per $100, \$ 18.00$. Farorite; 20c each; doz., \$1.60; per 100, \$10.00.

Favorite; 20c each; doz., \$1.60; per 100, $\$ 10.00$

King Humbert; 20c each; doz., \$1.50; per 100, \$9.50.
CANNA -Con't.

Shides or Ihed-Green Foliage-

Dragon; doz.g \$1,50: per 100, \$\$.,

Fanal; doz., \$1.50: prer 100, \$4.50.

Wintzer's Colossal; dex., \$.50; per 100, $\$ 9.50$.

The President; 35c encin; do\%, \$3.00; per 100, \$19.50

Yellow and Oringe-Green Folitge-

Golden

Orange Bedder; 10\%., \$1.35; per 100, \$9.00.

The Gem; do\%, \$1.20: per ion, \$s.00.

Rose ind Pink-Greeu Holiage-

Hungaria; doz, si.3.; per 100, \$9.00.

Rosea Gigantea; do\%, $\mathbf{5 1 . 8 5}$.

Vuriegated-Greit Noliuge-

Gaiety; \$1.35; per 100, \$9.00.

Souy de Antoine Crozy; do\%, \$1.10; per 100, \$7.20.

Bronze and Dark Ieaved-

Dr. E. Ackerknecht; doz., \$1.10; per 100, \$7.20.

Wyoming: doz., \$1.10; per 100, \$7.20.

Varouna; 35e each; doz., \$3.00; per 100, $\$ 19.50$

CINNAMON VINE; doz, 60e; per 100, $\$ 4.00$

FUNIIA, True D:y Iily, (Hosta). Subcordata; 3óc each; do\%., \$2.0.0.

Unduot: Variegata, 30e eaeh; doz. \$2.00.

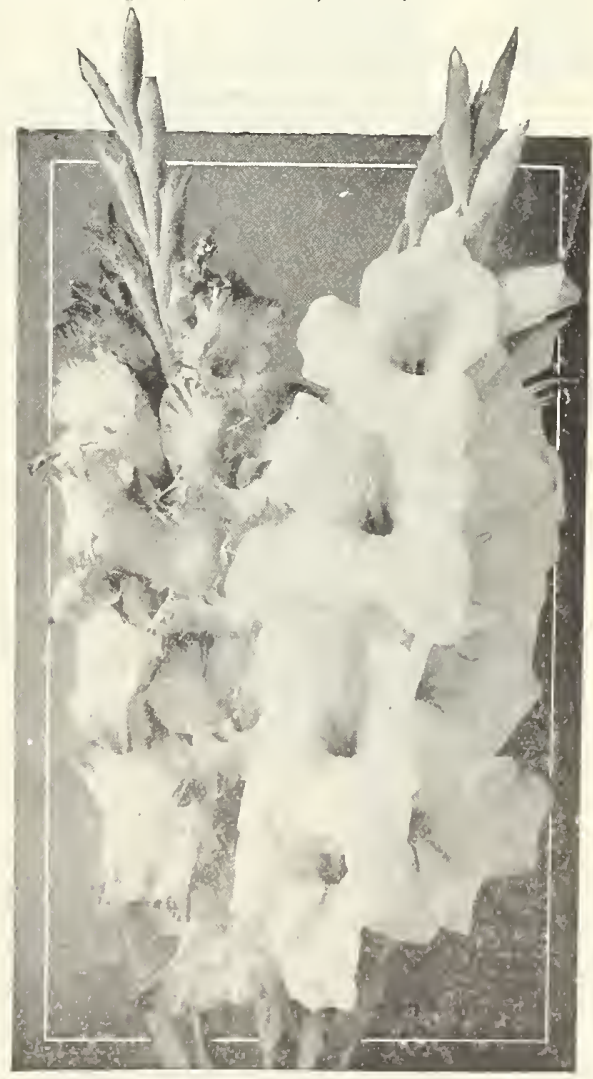

AYRES GIANT GLADIOLI 


\section{GLADIOLI.}

Ayres, New I'rimulinus Hybrida

The most graceful in form profuse in bloom, and artistic The most graceful in form profuse in bloom, and artistic in color of all Gladioli. They have made a sensation wherever they have been exhibited and will be

GLADIOLI. Standare Varieties-

America. Pink; doz, 65e: per 100, \$4.50.

Baron Hulot. Blue; doz., \$1.50; per 109, \$9.50.

Halley Orange red.

Kunderdi Glory. Ruffled cream; doz., 90c: per 100, \$6.26.

Mrs. Frances King. Scarlet; doz., G5c; per 100, $\$ 4.50$.

Mrs. Frank Pendleton, Jr. Pink and red; doz., 85e; per

100, $\$ 9.00$.

Mrs. Watt. Cherry red; doz. 90e; per 100, $\$ 6.25$.

Niagara. Rose carmine marking; dos., 90c: per $100, \$ 6.25$. Panama. Deep pink; doz., \$1.35; per 100, \$9.00.

Peace. Large white; dlom, 90c; per $100, \$ 6.25$.

Schwaben. Canary yellow; doz., $\$ 1.50$; per 100, $\$ 9.50$.

Gladioli in Mixture--

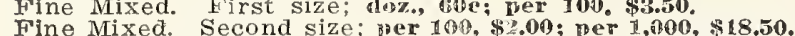
Special Light Shades, mixed; doz, 75e; per 100, \$4.00.

HEM EROCAlits. Lemon Lily. Flava: 20e each; 3 for 50c. Golden Lily. Florham; ace each; 3 for 50e.

\section{HARDY LILIES.}

Auratum. Crimson and yellow. Each 39e; 3 for $\$ 1.00$.

Hansoni. Yellow. Waelh Soe; 3 for \$2.00.

Henryi. Apricot. Wach $80 \mathrm{e} ; 3$ for $\$ 2.00$.

Longiflorium Gigantern. White. Wach 40c; 3 for $\$ 1.00$. Speciosum Melpancue. Crimson. Each 40c: 3 for $\$ 1.00$. Speciosum Robrum. Deep rose. Each 40c; 3 for $\$ 1.00$. Tigrinum Fortunel Giganteun. Fach $40 \mathrm{e} ; 3$ for $\$ 1.00$. Tigrinum Flore Pleno. Eachin $40 \mathrm{x} ; 3$ for $\$ 1.00$.

LILY OF THE VALLEY. Field grown clumps. Divided; doz., 75e.

MLADERIA VINE. Doz., 7ש̌c.

MONTHiftiA. Crocosmiacfiora. Mixed colors. Doz., \$1.50.

\section{TUBEROSE.}

TUBERose. Excelsior Pearl, Double. First size; doz., 60e? per 100, \$4.50.

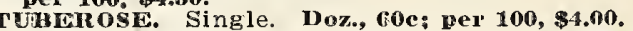

Note-Three or more bulbs or roots will be supplied at the dozen rates; 25 or more at the 100 rates, and 250 or more at the 1,000 rates.

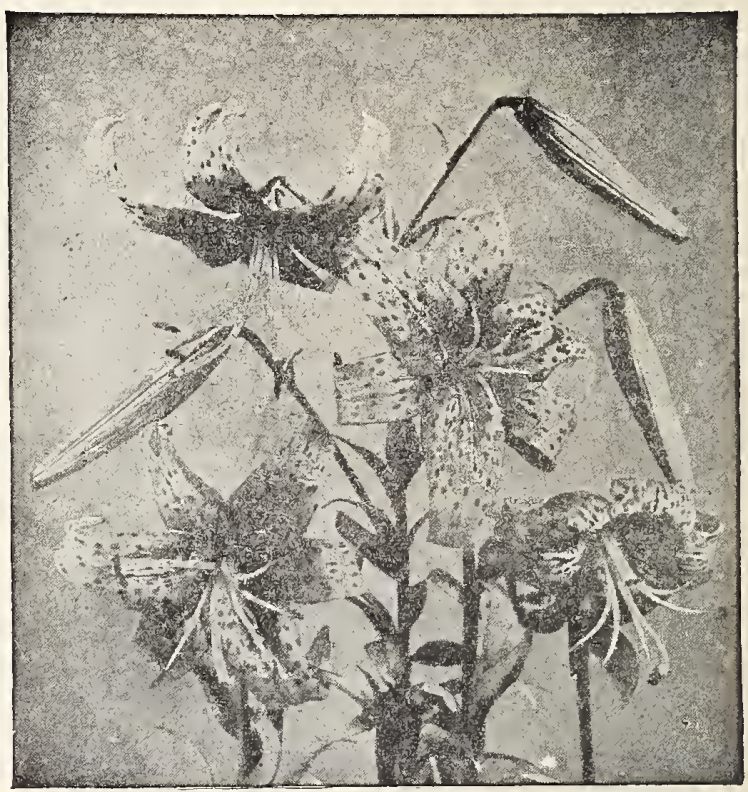

TIGRINUM OR TIGEF LILY

\section{THE BRYSON AYRES FAMOUS DAHLIAS}

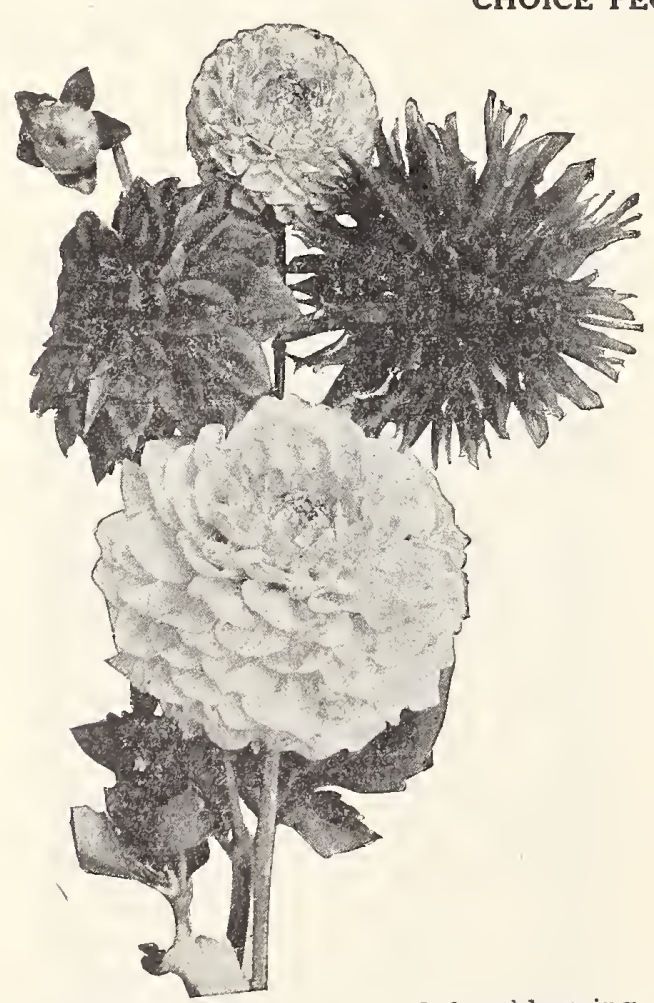

SUNNY SLOPE CRtiarl. Large and free-blooming. Cream red; suffused with salmon

ing: 30c each; doz., \$3.00. SUN Y SLOPR CIREAM. Large. and fr

suffused yellow; 30c each: doz., \$3.00. SUNNY SLOPF SALMON. S

amber; 300 eath; doz, \$3.00. SUNY SLOPA Wrine continuously on long stems well of giant size, borne continuously

H. J. LOVINIS. A delicate combination of white and lilac. Harge flowers on exceptionally long stems; 25e each; doz., \$2.50.

HORTUL VUS BUDDE. Orange-scarlet shading lighter toward the edges of the petals, with a glistening bronze or copper sheen:45e each: doz., \$4.00.

JOHN D. ROCKEFELLER. Pinkish salmon-buff. Very early and free-flowering; 30e each: doz., \$3.00. MrS. HUGH DICIKSON. Exquisite rich
with light buff-pink; 30c each; doz., $\$ 3.00$.

MRS. W. E. WIINERAY'. A lovely rose, suffused clcar yellow, deepening at the base of petals: 30e each; doz., $\$ \mathbf{3 . 0 0}$ MIES. JOHN GRIBBEL. Light salmon-pink, heavily flushed

amber and yellow; 30c each; doz., \$3.00. formed blooms. Soft mauve shading lighter toward the outer edges of the petals; 45e; $1 / 4$ doz., $\$ 1.25 ;$ doz., $\$ 4.00$.

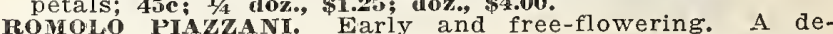
lightful blend of rose, salmon, and amber. Splendid for cutting. 30c each , doz.. \$as.00.

THE center. The petals are much twisted and gracefully curved; 45e each: $1 / 4$ doz., $\$ 1.25 ;$; doz., $\$ 4.00$.

HORTULATUS WIITL. Vैery large, free-flowering, pure white; 45e each; $1 / 4$ doz., \$1.25; doz.o \$4.00.

DARON G. DE GRANCY." Pure, waxy white of perfect form. A profuse bloomer; 25e each; doz., \$2.50.

PEONY-FLOWEIRED DAILIAS IN MIXTURE; 100 for $\$ 7.50$; doz, $\$ 1.15$.

AYASHA. Clear, light yellow of largest size and finest Form; 40e each; $1 / 4$ doz., $\$ 1.10$; doz., $\$ 4.00$.

DR. TYReELL. Rich golden bronze shading to bronzy DR. TYRRELL. Rich golden bronze shadi
red at base of petals; 25c each; doz., \$2.50.

red at base of petals; 25c each; doz., \$2.50.
HORTULA yellow. Flowers of immense size; ;5e each; $1 / 4$ doz., \$2.00. JACI ROSE. Brilliant crimson-red. Well established in popularity; 20 ce each; doz., \$2,00.

JOHN WANAMAKER. Deep lavender-pink. Very free-flowering; 45e each: $1 / 1$ doz., \$1.25; doz., $\$ 4.00$.

MELoDY. Canary-yellow petals tipped with creamy white.

Of large size; 20c each: doz., \$2.00. flowering; 45e each; $1 / 4$ doz., $\$ 1.20$; doz., $\$ 4.00$.

MINNIE MECULIOUGH. Soft golden yellow, tipped bronzy red; 20c each; doz., \$2.00.

MRS. C. H. BRECK." Soft yellow, deeply suffused carmine. Large flowers in profusion; 45c each; 1/4 doz., $\$ 1.20$; doz., Large.

ORANGE BEAUTY. Deep, rich orange-an unusual shade: 450 each $1 / 4$ doz. 51.25 , doz

YELUOW GIANT (Jan Olieslagers). Rich, buttery yellow. Very free-flowering; 30c each; doz., \$3.00.

AYRES' TRIA I, GROUND MLXTURE. Each 15e: Doz., \$1.25. 


\section{LANDSCAPE DEPARTMENT ORNAMENTAL AND FLOWERING SHRUBS}

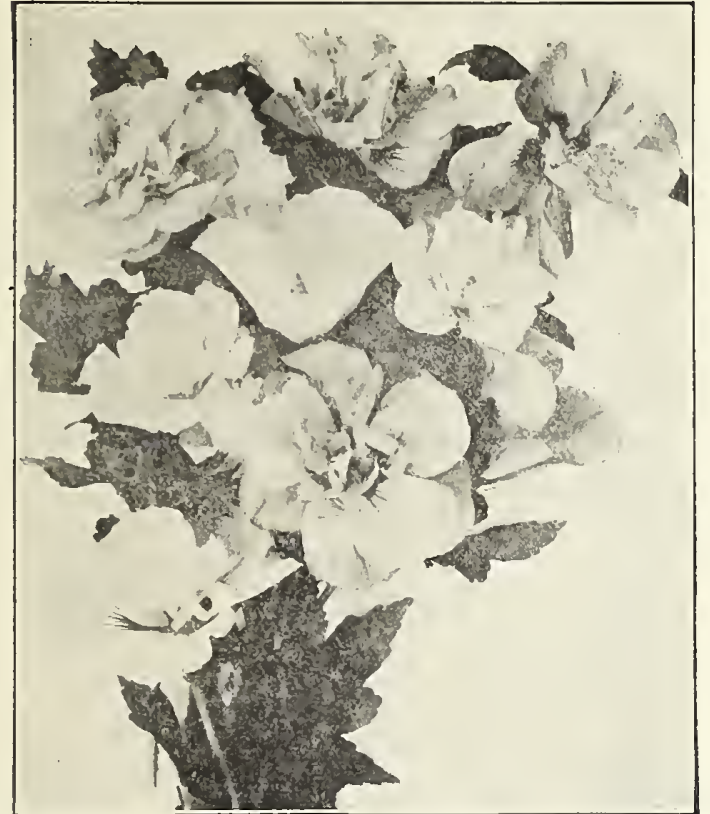

ALTHEA'S BLOON THROUGHOUT SUMMER AND FALL

ALTHEl. Tose of Sharon, all colors, 2 to $3 \mathrm{ft}$. Eacli $75 \mathrm{c}$ Specimen Shrubs, $\$ 1.50$ to $\$ 6.00$ each.

ALMOND. Double Flowering. Pink or white, 2 to $3 \mathrm{ft}, \$ 1.50$ Each.

BARRERRY, Thumberg's (Japanese Barberry). 2 to $3 \mathrm{ft}$. Each 75e. Specimen plants, \$1.00 to \$2.50.

BUTTERFLY RUSH (Buddiea). 2 years old. Each $75 c: 4$ years old. Each $\$ 2.00$.

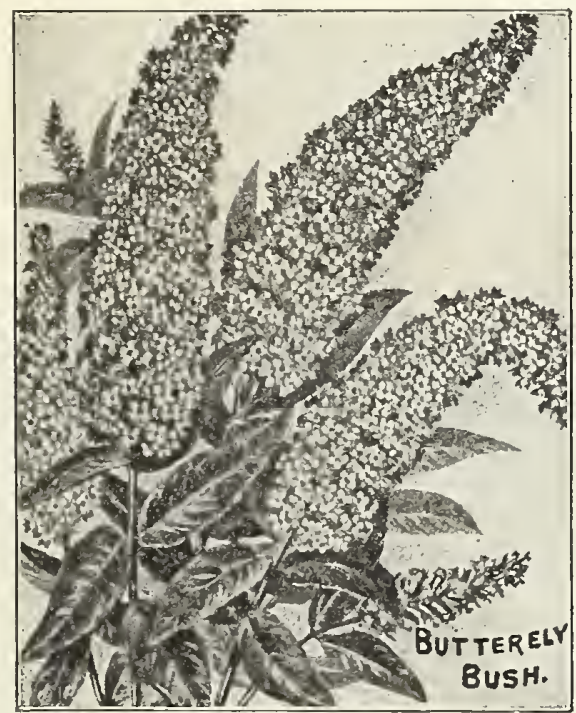

CURRANT. Flowering, 2 to $3 \mathrm{ft}$. Each -5e. Specimen Shrubs, \$1.50 to \$3.00.

CRAB. Double flowering. Beautiful double pink flowers like tiny roses, 2 to $3 \mathrm{ft}$., \$1.50 Each; 2 to $4 \mathrm{ft}$, $8 \mathbf{s i n}$ each. CALYCANTHAS (Sweet Shrub), 2 to $3 \mathrm{ft}$ Each $\$ 1.50$.

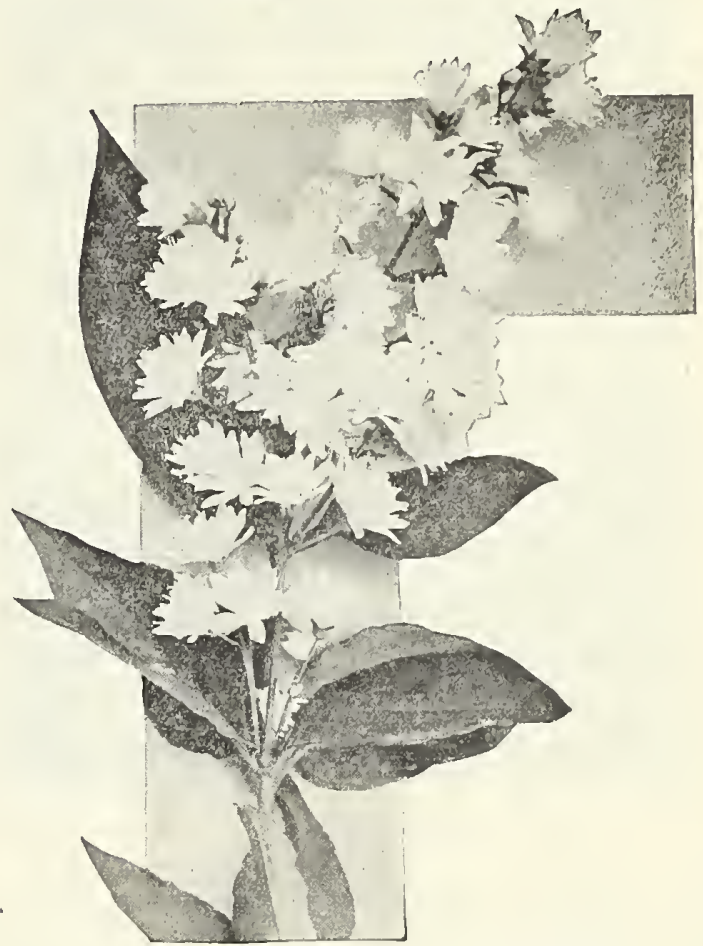

DEUTZIA, PRIDE OF ROCHESTER

DEUTzIA. Gracilis. A neat, dense little bush, rarely over 2 feet high, that blooms in May, wreathing its drooping branches with pure white flowers. Equally valuable for shrubberies and forcing. Fine for growing in front of taller shrubs. 18 to 24 inches, eich $75 \mathrm{c}$

Pride of Rochester. 18 to 24 inches. Each 75e. Specimen shrubs, \$1.50 to $\$ 2.50$.

Dogwood. Red twigrged. (Cornus Siberica alba). 3 to 4 ft, 80c. Specimen shrubs, \$1.50 to \$3.00.

DESMODIU. Graceful drooping flowers in late autumn; eacli $\$ 1.50$.

ELCAGNUS. Longiies, Edible red berries, 2 to $3 \mathrm{ft}$ : $\$ 1.00$ each. Specimen shrubs, \$2.00 to \$4.00 e:1ch.

Augustifolia. Silver leaves and yellow flowers. Specimen shrubs, \$1.50 to $\$ \mathbf{1 . 0 0}$.

EIDER. Cut-ieaves. (Sambucus Nigra Liciniata), 2 to 3 ft, (60e; Specimen shrubs, \$1.50 to \$2.00.

FORSYTHU SUSPENSA (Grolden Biell), 2 to $3 \mathrm{ft}$ each 60e. Specimen bushes, \$1.50 to \$3.00.

FRINGE. Purple or Mist Trec. (Rhus Cotinus). Specimen shrubs, \$1.00 to \$2.00.

White. (Chionanthus Virginica). 3 to $4 \mathrm{ft}$., soc. Specimen shrubs, \$2.00 to $\$ 3.00$.

IIONEYSUCIKLE. Fragrant, 2 to $3 \mathrm{ft}$ 75e. Specimen shrubs, $\$ 1.50$ to $\$ 5.00$.

Ledelbour, 2 to $3 \mathrm{ft}, 75 \mathrm{c}$.

Red Tartarian. Specimen shrubs, \$1.50 to $\$ 5.00$.

Pink Tartarian. Specimen shrubs, \$1.50 to \$.5.00.

Morrow's (Lonicera Morrowi). 2 to 3 ft., 75e. Specimen shrubs, \$1.00 to $\$ 10.00$.

HOIzSE-CHESTNUT. Dwarf. (Aesculus Parviflora), 18 to 24 inches, $\$ 1.50$.

HYDR A NGEA. Iarge-Flowered. (Hydrangea Paniculata Grandiflora). $3 \mathrm{ft}$., \$1.00. Specimen shrubs, \$2.00 to $\$ 3.00$ Tree. Same as the former, but grown in tree form, and bears great trusses of flowers. Specimen shrubs, \$1.50 to $\$ 3.50$

Arborescens Grandiflora. (Everblooming Snowball Hydrangea). 3 to $4 \mathrm{ft}, \$ 1.00$. Specimen shrubs, \$2.00 to $\$ 3.00$ 


\section{ORNAMENTAL AND FLOWERING SHRUBS---Cont.}

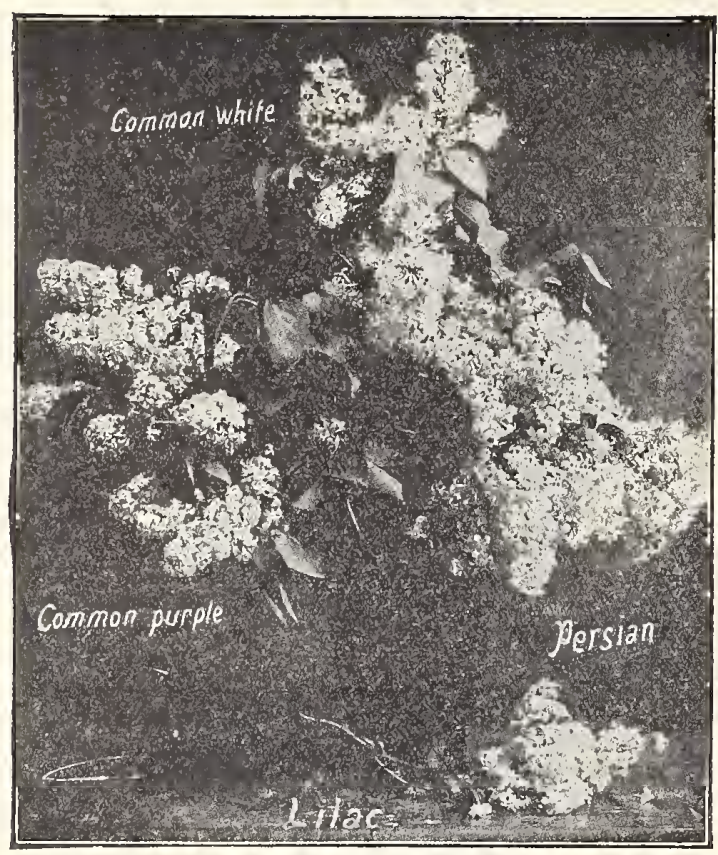

A YRES LILACS

LILAC. Common Purple. (Syringa Vulgaris). 2 to $4 \mathrm{ft}$. s0c. Specimen shrubs, \$1.50 to $\$ 6.00$.

Common White. (Syringa Vulgaris Alba). 3 to $4 \mathrm{ft}$, \$1.50 to $\$ 6.00$.

White Persia. (Syringa Persica Alba). 2 to $3 \mathrm{ft}$. soe. Specimien shrubs, $\$ 1.50$ to $\$ 6.00$.

Giant Tree (Syringa Japonica). 2 to $4 \mathrm{ft.,} \mathrm{Soc.}$

Himalayan. (Syringa Villosa). 3 to $4 \mathrm{ft.,} \$ \mathbf{\$ 1 . 2 5}$. Specimen shrubs, \$1.50 to \$6.00.

NAMED FRENCH VARIETIES OF IILACS. The named sort ale much superior to the old type of Common Purple and White and bloom much earlier. 2 to $4 \mathrm{ft}$., \$1.25. Specimen shrubs, \$2.50 to $\$ \mathbf{5 . 0 0}$.

Alphonse Lavellee. Fine blue, shaded violet.

Bclle De Naney. Satiny rose; white center.

Charles $\mathbf{x}$. Reddish purple; large.

Dr. Masters. Clear lilac; shrubs.

rudwig Spacth. Dark purplish red; superb.

Marie Legraye. One of the finest white Lilacs.

Vichael Buchner. Dwarf; pale lilac.

Iadame Lemoine. Fine, double, white lilac.

President Carnot. Pale blue.

President Grevy. A beautiful blue.

President Viger. Bluish lilac; extra.

Rubra de Marly. Purplish red; fine.

roCUST. Pink. (Robinia Hispida), 2 to $4 \mathrm{ft} ., \$ 1.00$. Specimen shrubs, \$1.50 to \$3.00.

PIUM. Double-Flowering. (Prunus Triloba). 2 to $4 \mathrm{ft}$, \$1.50. Specimen shrubs, \$2.50.

PTIVET. Remel's (Ligustrum Regulianum). 2 to $3 \mathrm{ft}$, $35 \mathrm{c}$ in lots of 25 or more. $4 \mathrm{ft}$, $60 \mathrm{e}$ each in lots of 25 or nore.

Ibota. (Ligustrum Ibota). 2 to $3 \mathrm{ft}$, 35e cach in lots of 25 or more. $4 \mathrm{ft}$. G0e each in lots of 25 or morc. Specimen shrubs, \$1.00 to $\$ 2.00$.

Amoor River North. (Amurenee), Best adapted for this altitude, $2 \mathrm{ft}$., 25e each in lots of 25 or more. 2 to $3 \mathrm{ft}$., zive each in lots of 25 or more. 3 to $4 \mathrm{ft}$., $40 \mathrm{e}$ in lots of 25 or more.

QuiveE. Japau. (Cydonia Japonica). Specimen shrubs, $\$ 1.00$ to $\$ 2.50$.

SIHEIRAN PEA TRER (Caragana Arborescens), 4 to $5 \mathbf{f t .}$ $\$ 1.25$. Specimen shrubs, $\$ 1.50$ to $\$ 5.00$. SNowbaLL. Carles' (Viburnum Carlesli). .2 to $3 \mathrm{ft} ., \$ 1.00$.
3 to 4 ft., $\$ 1.50$.

Common. (Viburnum Opulus Sterile). Specimen shrubs, $\$ 1.00$ to $\$ 5.00$.

Wayfaring Tree. (Viburnum Lantana). 3 ft., 75c. Specimen shrubs, \$1.50 to $\$ 5.00$.

High-Hush Cranbery. (Viburnum Opulus). American type. Quite different from the regular type; leaves glossy green with red steams and are free from
ft., $\$ \mathbf{1 1 . 2 5}$. Specimen shrubs, $\$ \mathbf{2 . 0 0}$ to $\$ \mathbf{5 . 0 0}$.

SNOWnERRY. Red, or Indian Currant. (Symphoricarpos Vulgaris). Specimen shrubs, \$1.50 to $\$ \mathbf{2 . 0 0}$.

White. (Symphoricarpos Racemosus). 3 ft., $\$ 1.00$ each. Specimen shrubs, \$1.50 to $\$ 2.50$.

SPIRAEA. Anthony Waterer. Dwarf. 18 to 24 inches, 60c. Specimen shrubs, \$1.00 to \$2.00.

Argentea. (Golden Spirea). 2 to $4 \mathrm{ft}$, soe. Specimen shrubs, \$1.50 to \$3.50.

Hilliardii. 3 to $4 \mathrm{ft}$., soe. Specimen shrubs, $\$ 1.50$ to $\$ 3.50$. Bumbalda. Dwarf, 18 to 24 inches, 6oc. Specimen shrubs, $\$ 1.00$ to $\$ 3.06$

Reevesii Flore Pleno. Double. 3 ft., \$1.00. Specimen shrubs, \$1.50 to \$3.50.

Van Houtti. (Bridal Wreath). 2 to $3 \mathrm{ft}$, The each; 2 to 4 ft., \$1.00 each. Specimen shrubs, \$1.50 to \$5.04.

SUMaC. Cat-Leaved. (Rhus Glabra Laciniata). 2 to $3 \mathrm{ft}$, 1.25. Specimen shrubs, \$1.50 to \$2.00.

Frasant. (Rocky Mountain). 2 to $3 \mathrm{ft}$, soc.

SYRING. Avalanche. (Philadelphus Hybrids). 3 to $4 \mathrm{ft}$. 80e. Specimen shrubs, \$1.50 to \$3.00.

Grandiflora. (Philadelphus Grandiflorus). 3 to $4 \mathrm{ft}$. \$1.00. Specimen shrubs, \$1.50 to \$3.00.

Lemoinei. (Philadelphus Lemoinei). 2 to $3 \mathrm{ft}, 75 \mathrm{c}$. Specimen shrubs, \$1.00 to \$2.00.

Mock Orange. (Philadelphus Coronarius). 3 to 4 ft., soc. Specimen Shrubs, $\$ \mathbf{1 . 5 0}$ to $\$ \mathbf{5 . 0 0}$

Mont Blane. (Philadelphus Mont Blanc). 3 to $4 \mathrm{ft} ., 75 e$.

TAMARIX. Odessana. 2 to 3 ft., 75e. Specimen shrubs, $\$ 1.50$ to $\$ 2.50$

Hispida Aestivalis. 2 to $3 \mathrm{ft}$, 75e. Specimen shrubs, \$1.50 to $\$ 3.00$.

WEIGELA. Deshoisii. (Diervilla Hybrida). 2 to $3 \mathrm{ft}$, 6oe. Specimen shrubs, \$1.00 to $\$ 2.50$.

Eva Rathke. (Diervilla Hybrjda). 2 to $3 \mathrm{ft}$., \$1.00. Specimen shrubs, $\$ 1.50$ to $\$ 3.00$.

Rosea. (Diervilla Rosa). 3 to 4 ft., \$1.00.: Specimen shrubs, \$1.50 to $\$ 3.00$.

Rosea mana Variegata. 3 to $4 \mathrm{ft.,} \mathbf{\$ 1 . 0 0}$. Specimen shrubs, $\$ 1.50$ to $\$ 3.00$.

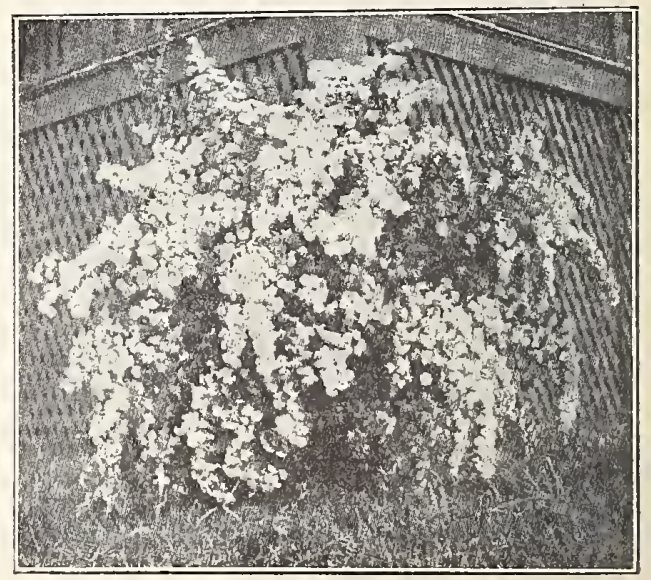

SPIRAEA V. H, BRIDAL, WREATH 
Shrubs classified as to height, color of flower and time of blooming.

SIIRUBS TIAT GROW 12 to 15 FEET HMH. Nome

Amorpha fruiticosa.

IBIOom in

Eleagnus angustifolin

SHIRIBS THI

Colutea arborescens.

Euorymus anericanus

Exochorda grandifle ra

Hibiscus in varicty

Philadelphus coronarius

Philadelphus coronarius

Philadelphus cor

Philadelphus coronarius$$
\text { lewisii }
$$

Rhodotypos kerrioides

Rhus cotinus

Rhus glabra

Rhus typhina

Rhus typhina laciniata.

Sambucus canadensis

Sambucus canade

Sambucus racemosus.

Spirae van Houteii..

Tamarix african

Tamarix gallica

Tanarix gallica indica.

Tamarix hispida estivalis... Purple

IBoom
June

girovi

s To 1: FEET HIGH.

Reddish-ycllow ..July

Sinall ycllow.....May

White .............May

Red, white, pur-

ple, pink .......Aug.-Sept.

Tamarix tetandra purpurea.

Viburnum lantana

Viburnum Ientage

Viburnum opulus

viburnum opulus sterilis.

Double white.....June

irhite

White

White

Purple

Crimson seed.... Fall

Crimson seed...... Fall

White ..........June

TVhite $\ldots \ldots \ldots$ June

white $\ldots . . . \ldots$....June

White ............. Anril

Roso-purple ….April

Pink

Bright carinine... July

Purplish pink....July

Creamy white........May

Creamy white.... May

White .............. May

April-May

\section{SHRUBS THAT GROW 6 TO 8 FEET HIGH.}

Calycanthus .......... June

Cornus alba $\ldots \ldots \ldots \ldots \ldots \ldots$. $\ldots \ldots$ Green-white ...... June

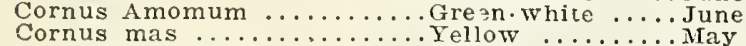

Cornus mas ............... Yellow $\ldots \ldots \ldots$ Green-white ...... Jun

Cornus stolonifera $\ldots \ldots \ldots \ldots$. Green-white $\ldots .$. . June

Cornus stolonifera aurea..... Green-white $\ldots$. . June

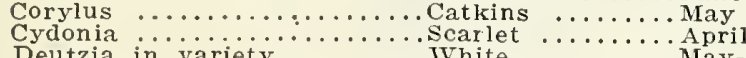

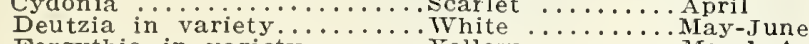

Forsythia in varicty......... Yellow $\ldots \ldots \ldots \ldots$ March-April

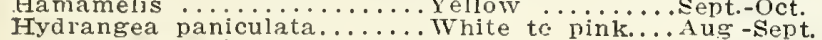

Hydrangea paniculata grandi-

flora

Jasminum nudiflorum

Largestroemia

Ligustrum amourense

Ligustrum ibota

Ligustrum regelianum

Lonicera fragrantissima

Lonicera morrowii ................

Lonicera tartarica rosea.

White

Yellow

Yellow ........ Mridsummer
Rose, red, white. July-Aug.

White …......June

White....... June

Pink $\ldots \ldots \ldots \ldots$ May

Pink .............M. May

Rose .............June

Philadelphus lemoinei.....

Yellowish-white...June

White ...........June

White $\ldots \ldots \ldots \ldots$ June

Physocarpus opuljfolia iuteus. White

Rhamus catarticus

Ribes gordonian
Ribes odoratum

Ribes sanguineum

Robenia hispida

Spirea billardii

Spirea Fontenayii aiba...

Orane .........June-July

Orange-rcd ......May-June

Golden-yellow ...May-June

Crimsen . .......May-June

Rose ................

Rose ............Midsummer

Deep rose ......June-July

Spirea Fontenayi alba....... White ..........Midsummer

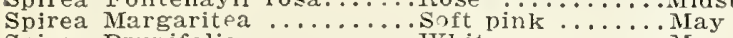

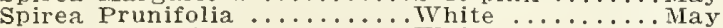

Spirea Reeresiana .......... White ............... May

Spirea Reevesiana fi. pi...... White ..................

Spirea salicifolia
Spirea sorbifolia $\ldots \ldots \ldots \ldots$
Spira

Spirae van houteii

White $\ldots$ W...July

Syringa josikea

White ........... April

Syringa josikea ............ Lilac ............ Apri

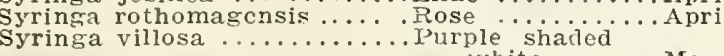

Syringa vulgaris

I'urple shated

May

Syringa, named virieties...... All colors .......... April

White ........... Nay

um molle

Viburnum tomentosum
Viburnum tomentosum

Viburnum to

Weigelia in variety

Greenish-whitc ...June

White ............. May

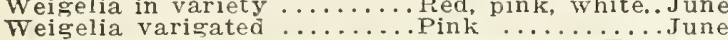

Abelia SHRUBS THAT GROW 3 TO 6 AEET HIGH.

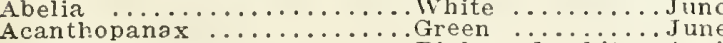

Amygdalus $\ldots \ldots \ldots \ldots \ldots \ldots$. Pink and white... April

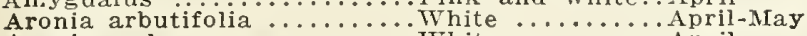

Aronia melanocarpa ........ White ........... April

Benzoin a estivale ........... Inconspicuous ...Apri

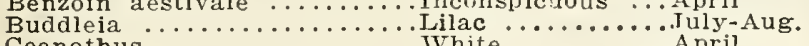

Ceanothus $\ldots \ldots \ldots \ldots \ldots \ldots \ldots$ White $\ldots \ldots \ldots \ldots$. White $\ldots \ldots$. . . . . .

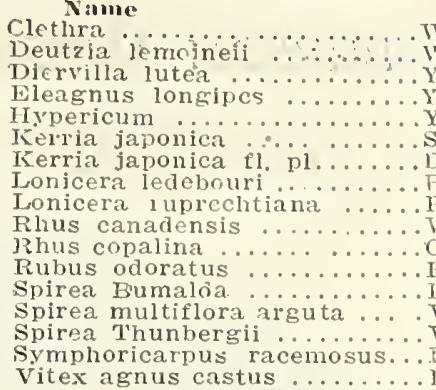

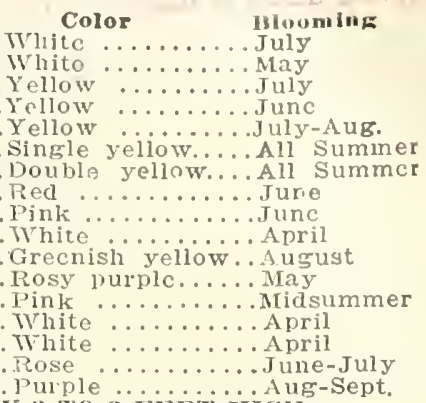

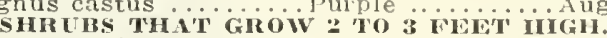

Berberis illicifolia

Berberis Thunbergii

Desmndium

Deutzia gracillis

Potentilla fruitieussa

Spirea callcsa, var. alba.

Spirea callosa, var. Froebelli..

Stephandra flexuosa

\section{SHRUBS THAT GROV I TO 2 IEET HIGH.}

Lonicera nitida

Lonicera piliata

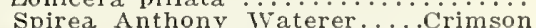

\section{ony waterer}

Baby Rambler Roses.-For low hedges in the Rose garden, all of the Baby Ramblers are excellent, giving a wide range of color.

B'erberis Thunbergii.-One of the finest and hardlest. for low dwalf hedges.

Hibiscus Syriacus in varieties.-For large screens

Ligustrum amourense (North). -The hardy Amoor River

Privet for sections north of Quincy, Illinois, where the Ovalifolium is not hardy enough

Ligustrum ovalifolium (California Privet). The great almost evergreen hedge so largely planted in St. Louis.

Lonicera nitida. A new plant just added to our list.
Will take the place of B'oxwood for edging. Can be kept vithin 1 foot high.

Lonicera piliata.-A form of the above, only has somewhat larger leaves and somewhat stronger growth

Philadelphus in variety.-Fine for screening, and where

all informal hedge is desired.

Rhodotypos.-Makes a beautiful informal hedge 6 to 8

feet 'high.

Spirea Anthony Waterer.-Makes a beautiful low hedge, and if flower heads are kept cut as soon as petals fall will bloom all summer.

Spirea Van Houttei-Makes a beautiful hedge or screen.

hould be more largely used on large grounds.

\section{SHRUBS WITH BERIRES IN FALL AND WINTER.}

Aronia al butifolia

Aronia melancarpa

Berberis Thumbergi

Callicarpa purpurca

Colutea arborescens

Cornus alba siberica

Cornus amo mas

Cornus mas …....

Elcagnus augustifolia

Eleagnus lon gipes
Euonymus alatus

Eunnymus americanus

Hlex verticillata .....

Height.

Ligustrum amourense

Ligustrum ibota

Ligustrum Regelianum

Lonieera Bella albid

Lonicera morrowi

Rhamnus catharticus

Rhis canadensis

Rhus copalina

Rhus typhina

Rhus typhina laciniat

3 to $6 \mathrm{ft}$

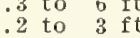

$\begin{array}{llll}2 & \text { to } & 3 & \mathrm{ft} \\ 2 & \text { to } & 3 & \mathrm{ft}\end{array}$

8 to $12 \mathrm{ft}$.

6 to $8 \mathrm{ft}$
6 to $8 \mathrm{ft}$

6 to $8 \mathrm{ft}$

$i_{2}^{6}$ to $8 \mathrm{ft}$ to $15 \mathrm{ft}$.

3 to $6 \mathrm{ft}$.

3 to $6 \mathrm{ft}$.

8 to $12 \mathrm{ft}$.

6 to $8 \mathrm{ft}$.

6 to $8 \mathrm{ft}$.

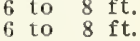

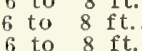

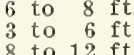

8 to $12 \mathrm{ft}$

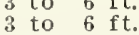

6 to $8 \mathrm{ft}$.

Sambucus canadensis

Sambucus racemosus

8 to $12 \mathrm{ft}$.

Symphoricarpus racemosis.. 8 to $6 \mathrm{ft}$. .

Viburnum dentatum ......6.6 to $8 \mathrm{ft}$.

Vilurnum lantana
Viburnum lentago

Viburnum lentago
Viburnum molle

Viburinum opulus SHRUBS WITH COLORED BAR

\section{Name
Cornus alba}

Cornus amomum

Cornus sanguineum

Cornus stolunifera

Elearnus angustifolia..... i2 to 14 it.

Eleagnus longipes

Euonymus alatus.

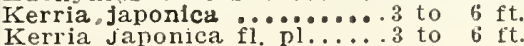

\section{Scarlet}

Black

Red

Deep violet

Bladder-like pods

White

Black

White

Yellow

Red

Scarlet and orange

Rosy red

Red

Blue-black

Black

Red

Red

Red

Scarlet seed

Scarlet seed

Crimson seed

. Scarlet seed

Reddish purple

Purplish-black

Red

White

Black

Bluish-black

Purplish-blize

Red 


\section{A GARDEN OF ROSES}

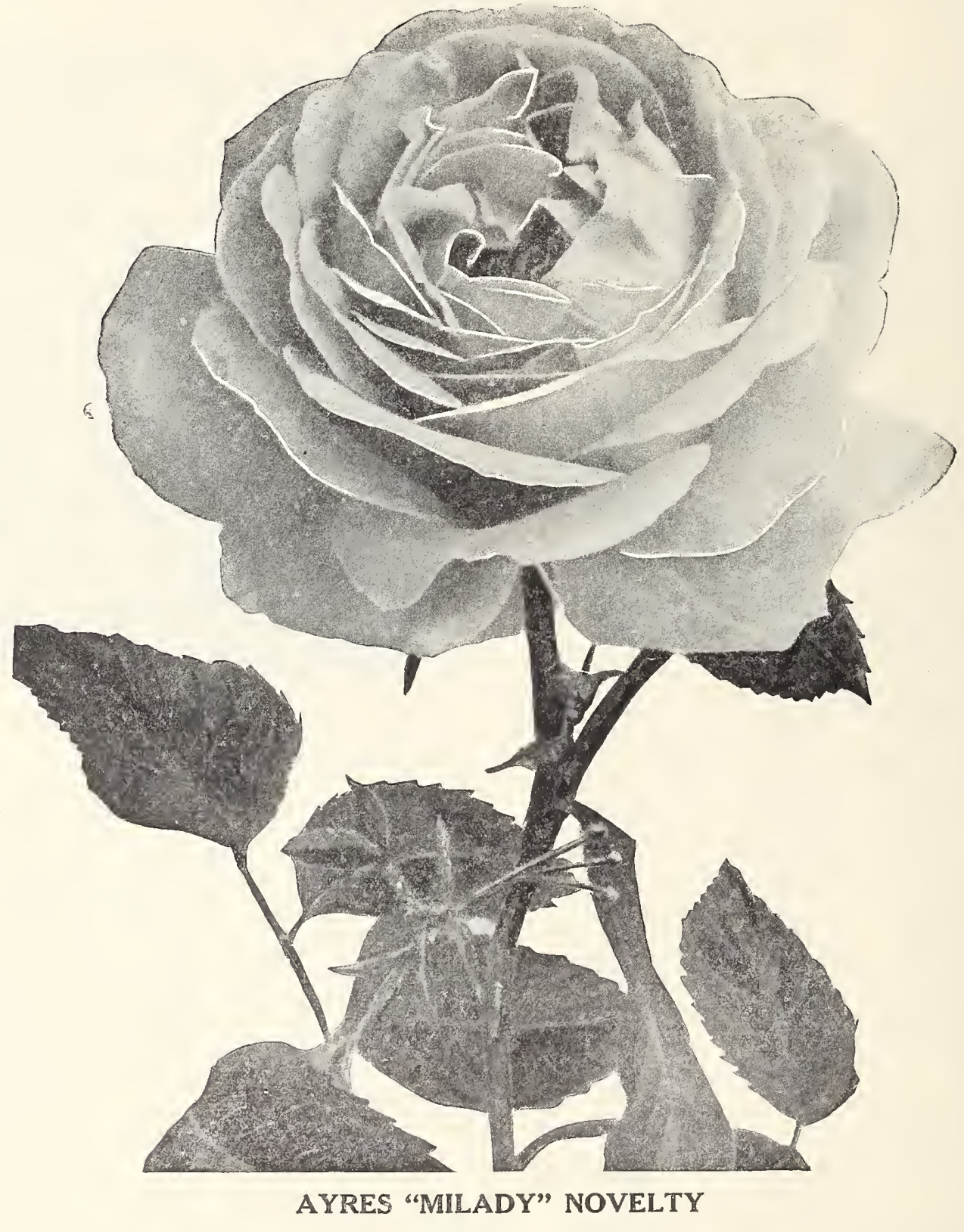

(See Page 15)

\section{AYRES HARDY EVER-BLOOMHG HYBRID TEAS}

STRONG TWO-YEAR-OLD BUSHE, 75c EACH, \$7.50 DOZEN.

THREE-YEAR-OLD BUSHES,

Our Rose Bushes Bloom Profusely the First Season.

This is the class of roses for general planting everywhere. The great advantage claimed for them is that they combine the hardiness of the Hybrid Perpetual with the constant blooming qualities and delicious fragrance of the Tea Roses. These varieties we list include only the choicest, and your surprise will come from the quantities of beautiful blossoms they produce. Hardy in all localities and without protection, except in the Northern States, where a mulch should be given them.
$\$ 1.00$ EACH, \$9.50 DOZEN.

AMERICAN MEAUTY. Very large and fragrant. Rather delicate; constitution requires especially well drained soll: rich crimson.

CAROLINE TESTOUT. Satiny pink, very large flowers. Excellent habit.

DUCHES DE WELLINGTON. Intense saffron-yellow, changing to a coppery yellow as the flowers develop; fragrant and free flowering.

GRUSS AN TEPLIPZ. Medium size, intense scarlet-crimson. Strong grower, sweet scented and persistent bloomer. One of the best roses.

GENERAL MEARTHUR, As an all-round garden rose, there is no variety of its color, a rich crimson, that will give better satisfaction. 
HYDRID TEA ROSES.

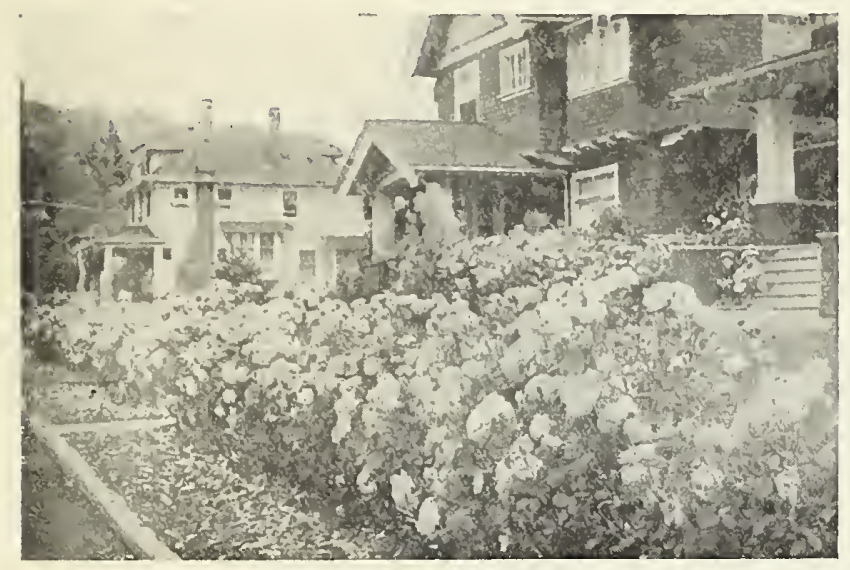

PROFUSEL BLOONIS CAROINE TESTOUT ROSES

GEORGEOUs. Bnds coral-red, shaded with yellow and rose; very beautiful.

HoOSIER IBEIUTY. Rich dark red, fine budder, and very hardy and frabrant.

HADLEY. Darkest velvet color, fragrant and free flowering.

JoNKEer J. L. Hock. Greatly improved La France, imperial pink; wonderful keeping qualities. The flowers are of large size, perfect form and highly perfumed.

KILLARNEY QUEEx. Deener pink than Killarney, producing strong stems and long pointed buds; very hardy.

KHLIARNEY WiITE. White, slightly tinted pink, long pointed buds, free bloomer, and no doubt one of the best white roses.

KILLARNEY BRILLIANT. Fich shade of rosy carmine, almost double.

KAISERINE AUGUSTA VICTORIA. Soft pearly white. Very fragrant and productive.

LADY HILLINGTON. Beautiful copnery shade of apricotyellow, pointed bud, very free flowering.

LADY PIERRE. Deen copper reddish-salmon, flushed fawn and copner, an icleal variety.

LA FRANCE. One of the best nink roses, very fragrant.

Los AxGELEs, an improved Marshal Neil and more fragrant. Flame nink. fold at hase of petal.

LYON ROSE. The long buds are tipjed coral-red and chrome-yellow at the base: very fragrant.

MY MARYLAD. Very free bionmer: flowers loroe and double: color bright salmon pink. Should be in every

niks. B. R. CANT, Bright rose pink, a strong healthy grower and productive

MRS. AARON WARD. A remarkable floriferous variety of strong, vigorons, but compact, dwarf growth. pointed bud, full double flowers when open. Color a distinet Indian yellow, shaped lighter towards edges.

MiRs. Char Les Rissei... Long nointed buds, dark rosepink. one of the best keeners. Very fraprant and beautiful.

MADAM CHRISTY MLLER. Exquisite silvery pink, one of the best varieties.

opHeLiA. Delicate shade of salmon-yellow. shaded with rose, floriferous and beautiful.

RADIANCE. An ideal beding variety of renarkable free flowering habit of a brilliant rose-pink. One of the best garden roses; good kecping qualities.

RED RADIANCE. Rosy-crimson. vigcrous and productive, except color same habit as Fadiance.

RICHMOND RED. True shade of red. Tery hardy and prolific bloomer.

RHEA REID. Strong grower, and prolific blonmer, carmine rose color. Should be in every collection.

SUNBURST. A superb rose, of goorl, vigorous habit; buds long cup shaped. Color a rich yellow with orangeyellow center.

WILLOWMERE. Coral-red color, surfused with carmine in bud state, and opens to a large full flower of a rich shrimp-pink.

WM. R. SMITH. Creamy-white with rose shadings. Long pointed buds and an excellent bedder.

\section{NOVELTY ROSES.}

COLUMuL. Large double flowers. Decp pink. Very Drofuse bloomer.

PIEMIGK. Satin pink. Pointed buds. Very fragrant. Hardy grower.

BABY DOLI. Tiny buds, Rich apricot pink shading to yellow.

Moss Rosk. Beantiful slade of pink. Contrasting wonderfully with the mossy-like leaves. Very fragrant.

SHA WYER. Wonderfully formed buds. Cerise. Continuous bloomers.

MILADY. One of the best deen red velvety red roses. Very fragrant and profuse bloomer.

If UGOSA TOSES. Bcautiful bushes and highly ornamental owing to the large masses of deep red berries.

Any of the abovc, two-ycar-cld bushes $\$ 1.00$ each. $\$ 9.50$ per dozen.

\section{HARDY HYBRID PERPETUAL ROSES}

These roses are a most valuable class because of their large, sweet, brilliant colored flowers.

A MERICAN IBEAUTY. Very large and fragrant, rich crimson color.

GEN. JAQUEMINOT. Too well known to require a lengthy description. It still holds first place among the dark red roses, and is one of the most satisfactory that grow.

FRAU IARL DRUSCHKI. Color fine snow-white, free from any yellow or rose tints.

MADAME PIANTIER. The iron-clad white cemetery rose; bears hundreds of beautiful, snowy-twhitc fragrant blossoms.

PAUL NEYRON. One of the finest hardy roses ever grown. It bloms unceasingly from June to November on uniformly long, stiff, thornlcss stems, with immense cupshaped flowers. Color, a bright lose pink.

ULRICH HRUNNGR. Flowers good size and fine form with shell-shaped pctals. One of the most abundánt bloomers, color, cherry red.

Any of the above strong two-year-old bushes at $80 \mathrm{c}$ each, $\$ 8.00$ per dozen.

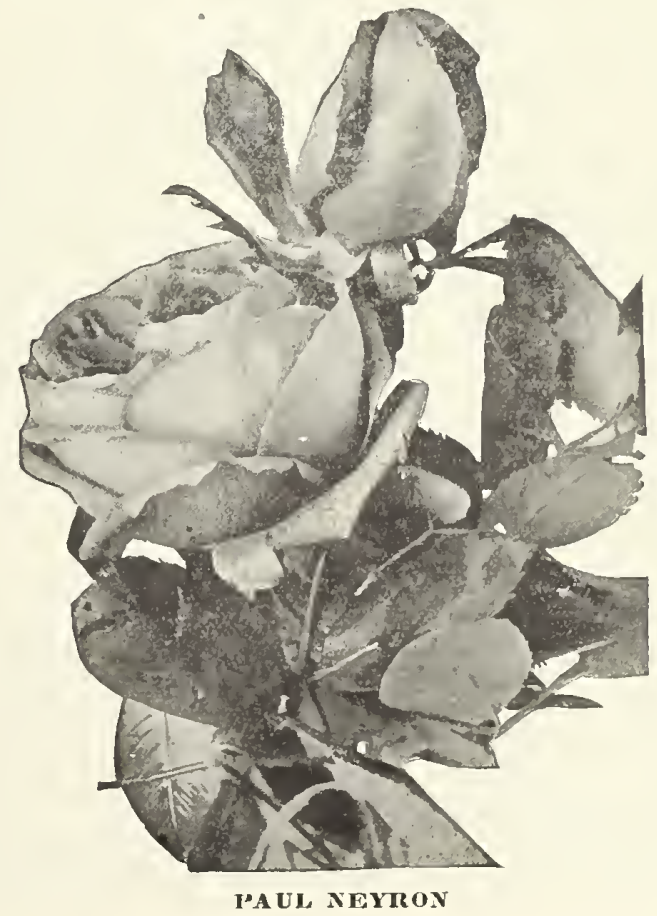




\section{ROSES-Cont.} HARDY CLIMBING ROSES.

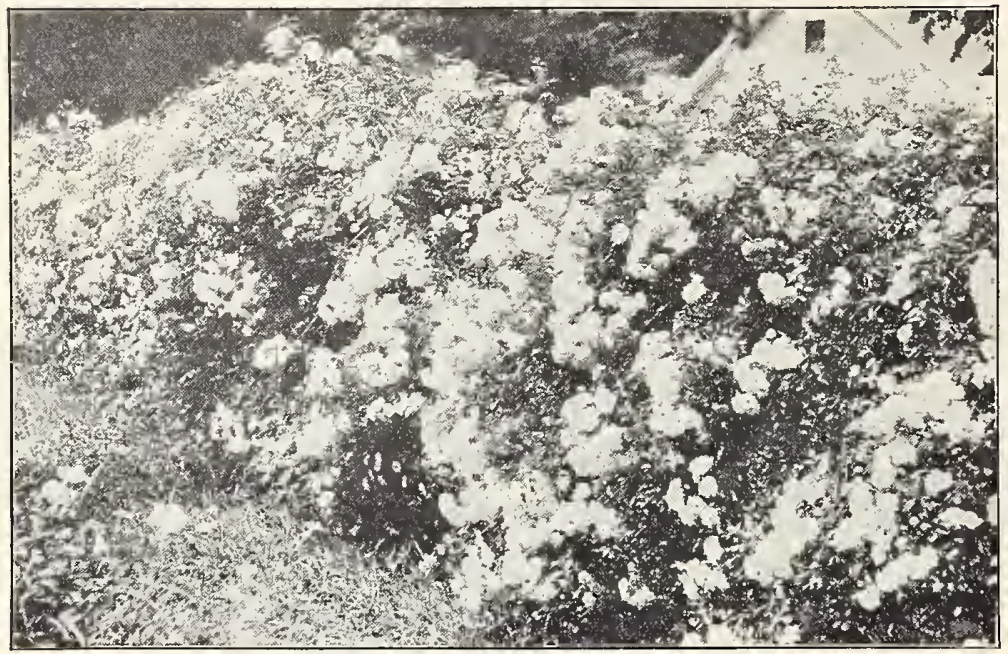

THOUSAND REAUTIES ROSE

YOUR CHOICE, ANY VARIETY. EXTRA STRONG FOUR-YEAR-OLD SPECIMEN PLANTS, \$2.00 EACH; $\$ 20.00$ PER DOZEN.

TWO-YEAR-OLD PLANTS, $\$ 1.00$ EACH; $\$ 10.00$

\section{PER DOZEN.}

Need No Protection Even in the Coldest Climate.

Very few vines give such an abundance of blossoms as the Climbing Roses. Again there is nothing in cultivation more beautiful and attractive. Surround your house and vamous climbing Roses. The stock we offer is choice and will give entire satisfaction.

AMERICAN PILLAR. Brilliant carmine rose, with a slight cream variegation and yellow stamens at center.

CHIMBING AMERICAN BFAUTY. This new climbing form of the famous rose so long the American favorite, is as lovely and fragrant as the bush form. The hardy climber blood with which it is crossed, gives healthy, perfect foliage and a strong climbing habit of growth; the abundant bloom being in prime before the June show of the bush type.

BALTIMOR BELL. Pale blush, variegated carmine-rose and white; very double; flowers in beautiful clusters, the whole plant appearing a perfect mass of bloom; one of

CRIMSON RAMBLEI. The most popular Climbing Rose: clusters of the brightest crimson, semi-double flowers.

DOROTHY PERKINS. A Climbing Rose, which is strong. vigorous growth and general habit, very closely ap-
proaches the popular Crimson Rambler its flowers, proaches the popular Crimson Rambler its flowers, full, double, and of large size for a cluster rose, and deliciously scented.

WHITE DorothY. Brilliant green foliage of splendid texture and free from milclew, flowers are a glistening white and borne in great trusses.

DR. VAN FLEFT. Rich flesh pink, long pointed buds.

WiLLIAII C. EGAN. Splendid pink flowers. A much-soughtfor rose; used for pillars and wherever an extremely hardy rose is wanted. Fine for hedges.

EXCELSA. A splendid Climbing Rose, remarkable in many ways but particularly in the brilliant fiery red or intense crimson-scarlet flowers, which are very double and borne crimson-scarlet flowers, which
in trusses of thirty to forty.

EMPRESS OF thirty to forty. pink, like an apple blossom. Splendid hardy Climbing

FLowitr OW FAIRIJILD. The Everblooming Crimson Rambler, brilliant crimson clusters of flowers.

LADY GAY. A seedling of the popular Crimson Rambler, which it closely resembles in habit and vigor of growth, but with flowers of a delicate cherry-pink, fading to a soft-tinted white.

MISS G. MESMAN (Climbing Baby Rambler). A grand acquisition to the list of Climbers. A strong grower and produces large compact clusters of bright carmine flowers continuously from June until frost. An easy grower and very valuable for porches, arches, etc.

PHILADELPHA IRAMBLEls. Fluwers produced in grand clusters: pure deep crimson: brighter than any of this clusters; pure deep crimson; brighter than any of this
class, holds color to the last; handsume foliage; blooms class, holds color to

PRAMIE QUENN. An old standard variety, and one that will be popular. No collection of hardy Climbing Roses is complete without it. Bright, rosy red, large compact, and globular flowers.
PERSIAN YeLLOW. A favorite yellow climber.

RUSSEI.'S COTTAGE. Dark velvety crimson; very double and full; profuse bloomed.

SILVER Moov. Half double flowers, Very large. Pure white with yellow stamens.

THOUSAND BEAUTIES. (Tausendschon). The most sensational climbing rose. Imagine a luxuriant rose literally covered with thousands of large, double beautiful, bright blossoms and of the most delicate shade of pink. The color might be described as white, delicately fiushed pink which changes to rosy carmine. The name is depined from the many colors and the great variation in rived from the many colors and the great variation in color. The clusters consist of 10 to 15 blooms and a from the beginning of June until the last of July. There is no other rose in cultivation to compare with it, having but few thorns with magnificent foliage free from mildew and absolutely hardy in the open ground everywhere. This variety may also be grown in pots and forced into flower as is done with many of the tender varieties. In short it is the most remarkable rose of its kind in the world.

VEILCHEN Br.A U. (Blue Climbing Rose). It has always been most person's ideal to cultivate a blue rose, and wo are now in a position to offer such a variety. It has glossy, green foliage, a strong grower and producing steel blue flowers.

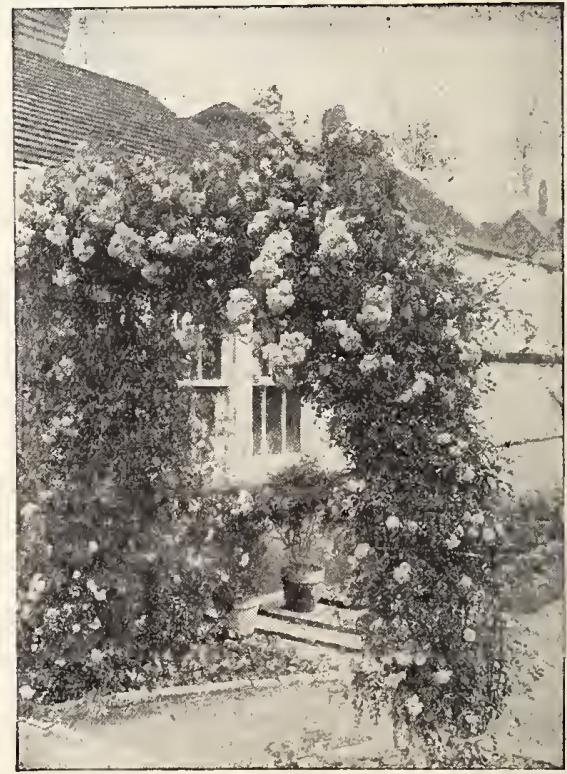

VEIICHENBLAU BLUE CLIMBER 


\section{FLOWER SEEDS AND PLANTS}

\section{HARDY PERENNIAL PLANTS}

The Garden of Hardy Fowers is of gorgeous boom from earliest spring until frost, glorified by its appropriate flowers from month to month, with new things each day to delight you. Year after year this goes on and the garden increases in beauty and loveliness, practically without any expense other than the first cost. Hardy flower's require less care and attention, are more free from insects and disease, yet producing abundance of beautiful blossoms. Among the Hardy Flowers are found all the old-time favorites and some of the noblest plants that have been dear to our grandmother's garden, famous in song and story - a fragrant memory of gay sweetness.

ALL PERENNIALS UNLESS OTHERWISE NOTED, LARGE CLUMPS, 35c EACH, SIX OF THE SAME VARIETY \$1.75

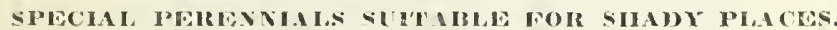
Achillea, Aegoporlium. Anemones, Aquilergias, Aralia, Asters, Baptisa Campanulas, Carnatins, Coreopsis. Chrysanthemums, Shastil Daisies, Delphinium, Digitalis, Funkias, Hemerocallis, Hibiscus, Iris, all varietics, Lily of the Valley (Convallaria), Lychnis, Rudbeckias, Papaver (Poppies) I Poppiestion All the above varieties Campanulas, Digitalis, lily of the Valley, Spirea and Violets.

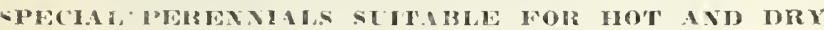
PIACEs. Asters. Boltonia. Coreopsis, Cassia, Carnations, Shasta Daisies, Giallaridia, Eulalias (Hardy Grasses). Hibiscus, Hollyhocks, Helianthus, Hardy Pinks, Liatris, Peonies, Phlox, Pyrethrum Rudbeckias, Sedun, Stokesia. Tritomas, and Yuceas. The above varietis will also thrive in partial shade. Other varieties not classified above may be used in general plantings.

ICHLL: Haule te veise. Dwalf compact grower; fine Double white flowers in profusion all summer.

IGrOSTEMUI. A clump of these flowers adds a dash of brilliant color to the border that is not equaled by any other flower.

1. coronaria (Rose Campion). Velvely crimson. June and July, $1 \frac{1}{2}$ to $2 \mathrm{ft}$.

A.YSSUM saxati:e moupatum. Masses of canary jellow, April ancl May. of incl.

AxCHUS I Dropmorei. A new perennial of great worth. It has gentian-blie flowers, in loug sprays. like the Larkspur. June and July. Each. stie.

ANEMONE (Wildflower). Flowers resembling a dainty, Single rose.

QQULEGI (Columbine). Too well known to need much description. The lardy garden is not complete without them. A vulgaris is perlaps the freest growing sort. Long spurled hybrids; arious colors; April to June.

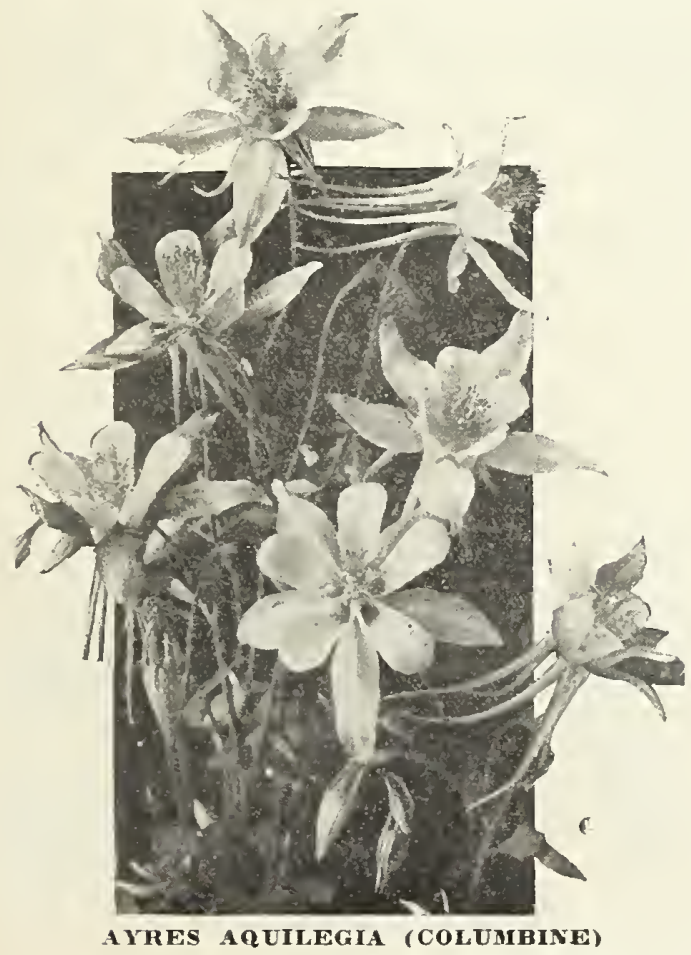

SEE PERENNIAL CLASSIFICATION LIST, PAGE 23. 


\section{BRYSON AYRES GARDEN BOOK}

\section{HARDY PERENNIAL PLANTS-Cont.}

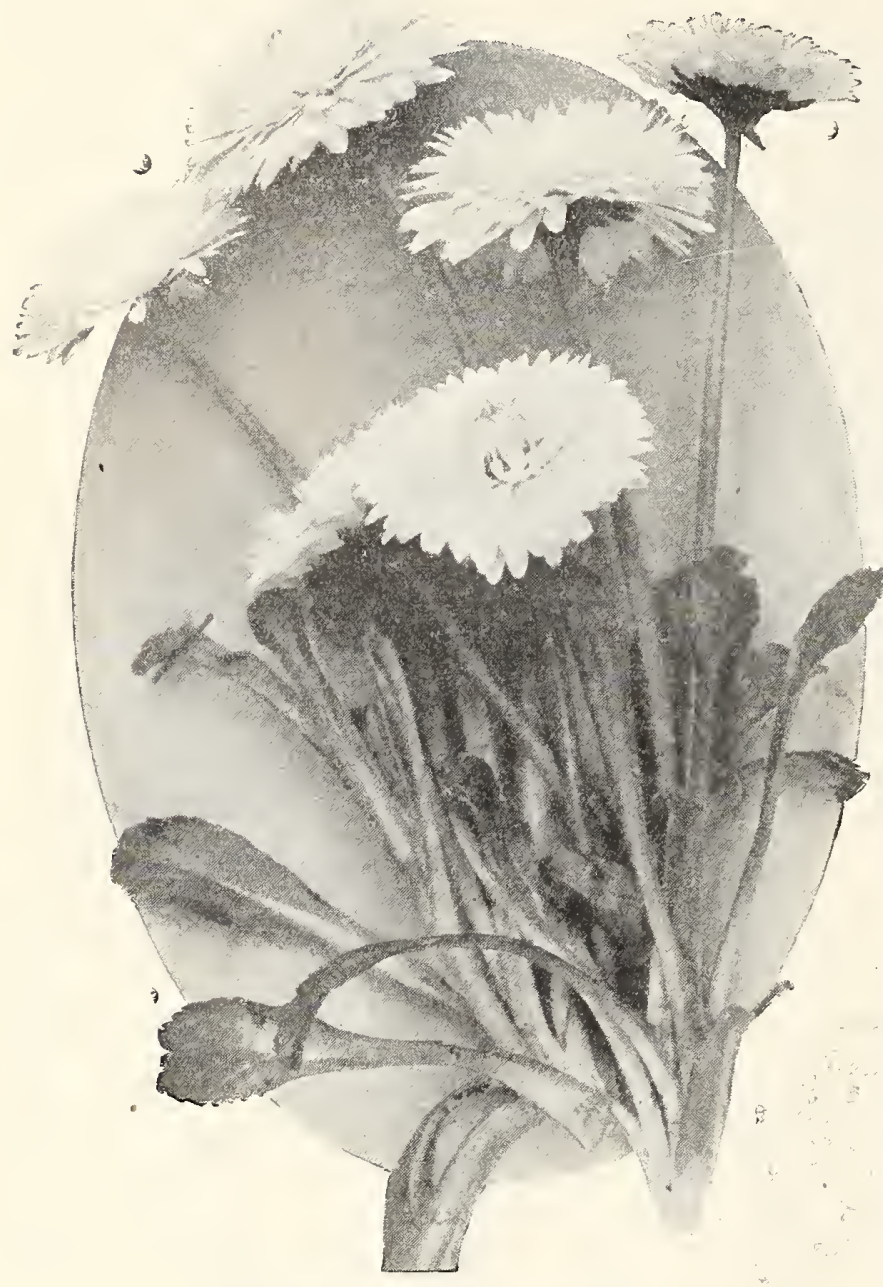

JAI'ANESE CHRYSANTIEMUMS

HARDY CHIEYSANTHENUMS-

Our collection consists of many varieties of every conceivable form and shade of color, and obtained at great ceivable from source, so that we have every reason to believe that we have the inest collection in the country.

Colors: Red, Yellow, White, Pink.

Shasta Daisy. A Burbank production of merit. Large, white. June to September

Japanese. Everblooming from June until frost. Golden yellow.

CONVALLAIRA (Lily-of-the-Valley). Clumps, soe each; Roots Toe per dozen.

COREOPSIS. The most common perennial and highly prized. The yellow cosmos-like blossoms come in profusion all summer.

MA NCEOLATA GIRA NDIFLORA. $1 \frac{1 / 2}{2}$ to $2 \mathrm{ft}$ Yellow. June to September.

ROSEA. Large growing, or rockery, with rose red flowers.

DIA NTHUS. Highly prized old-fashioned garden plants that are indispensab!e in the border.

BARBATUS (Sweet William). 1 to $1 \frac{1}{2} \mathrm{ft}$. Various colors. May to July.

PluUalues DIADruatrs (Scoteh Pinks), 9 in. Semidouble, clove-fragrant flowers in all colols. May and June.

DICENTRA SPECTAMHLS (Bleeding Heart). An attractive, early spring flower, that is most useful for cutting. 50 each; 6 for $\$ 2.75$.

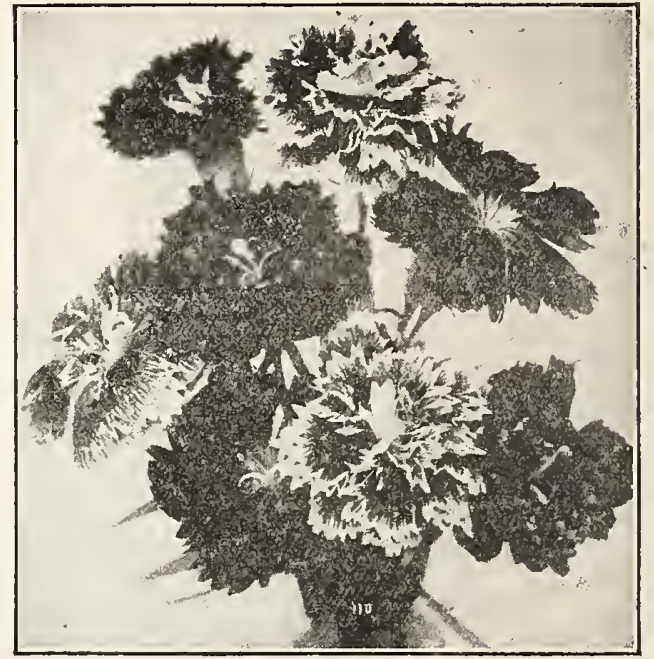

DIANTIIUS

DELIHINUM (Larkspur). One of the finest sights of modern gardens is a good collection of blooming Larkspurs. The tall, rich, showy flowers have been in hardy gardens for years. Good for cutting. We have some excellent strains.

CHINENSIS. 1 to $1 \frac{1 / 2}{\mathrm{ft}}$. Flowers in varying shades of blue, violet and white.

rokmosum. 3 it. Indigo. A favorite shade. June to ,Augrust.

HELLADONNA. The freest and most continuous bloomer of all; clear turquoise-blue.

GAILLARDIA (Blanket Flower). No plant in the hardy flower-garden gives more satisfaction than the Grillardia. It flowers in great profusion nearly all summer long. The leng, dry spells affect it very little. Cut-and-Comeagain is a good description of this plant.

GYPSOPHIL (Baby's Breath) Loose, feathery white flowers. highly suitable for bouquet purposes. Fine for mixing with sweet peas.

GOLUEN GLOW. Very double yellow. Flowers in August

HELENTUM SNEEZEWORT. Where a large mass of bloom is required, the Heleniums are excellent subjects.

HELIANTHUS (Perennial Sunflower). The perennial Sunflowers, without exception, are good for cut-flowers. They have not the Iarge coarse heads of the common, annual Sunflower. All the double ISunflowers resemble yellow dahlias.

HEMERoCALLIS (Day Lily). The Hemerocallis, or bronze and yellow Day Lilies, are among the most popular of hardy plants, and if all the kinds are planted, will Eive a succession of bloom all summer long. The long stems elevate the showy flowers well above the foliage. All are robust growers and satisfactory in every way. Do not confuse with Funkia.

WLAvA (Lemon Day Lily). $1^{1 / 2}$ to 2 ft. A lovely flower, nicely formed, fragrant. Yellow. June.

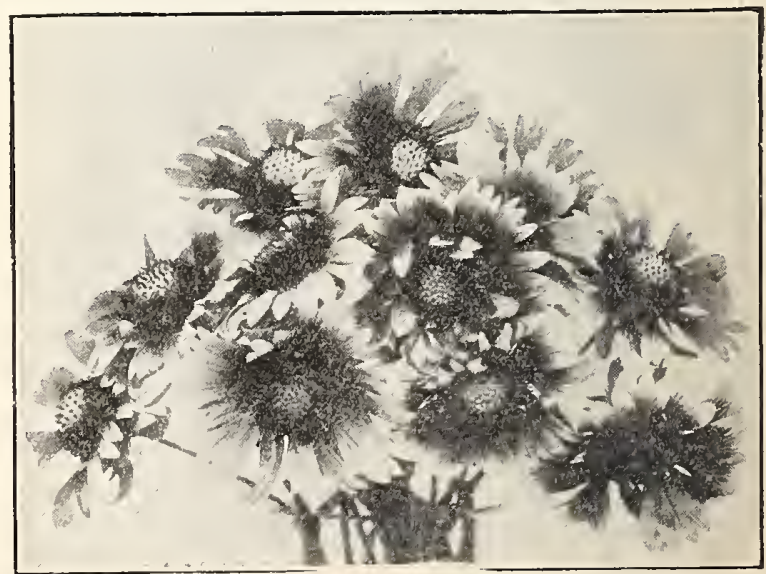

GAILIARDIAS 


\section{HARDY PERENNIAL PLANTS—Cont.}

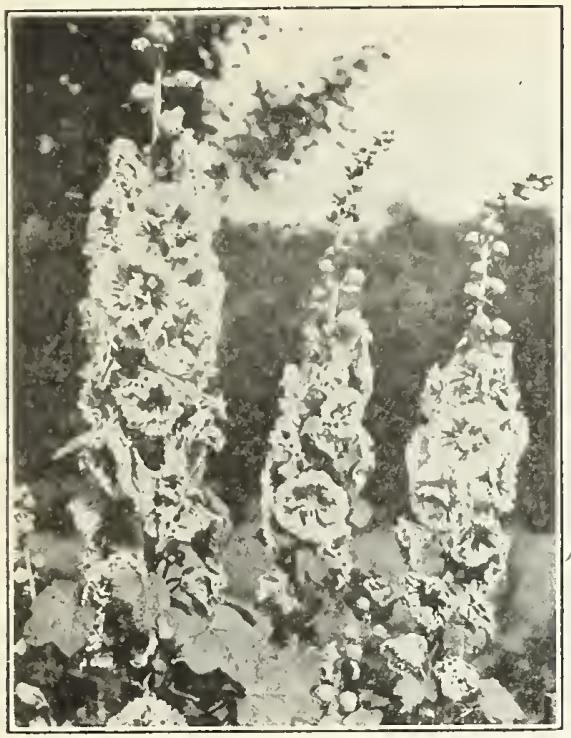

\section{ALLEGHENY HOLLYHOCKK}

AURANTICA. Large orange yellow flowers. 2 to $3 \mathrm{ft}$ June and July.

HEUCHEA (Alum Root). Dainty little plants with the lovellest coral-like flowers imaginable, borne in delicat or semi-shaded spots anywhere. Nice foliage.

SANGUINEA MAXIMA. 1 to $2 \mathrm{ft}$. Bright coral red, large flowers. June and July.

HIBISCUS. Mallow. Hibiscus is best adapted for planting in a damp place, along streams, or in positions where a large, showy plant is required.

Fed. Bright red; very showy.

Pink. Soft shades of pink.

White. White and very pale-tinted kinds. Any of the above Marvels, 2-year roots, 5 ce cach.

HoLLYHoCK. (Allegheny Hollyhock). The stately Hollyhock is increasing in popularity. The Allegheny Strain has prettily fringed eages. It was in great demand when introduced a few years ago, and the supply was quickly exhausted; but we now have a good supply. All kinds flower from. June to August and grow 6 to $8 \mathrm{ft}$.

DOUBI.E. Rosette flowers in white, pink, red, maroon and yellow.

IBERIS SEMPEIRIIRENS SUPERBA (Hardy Candytuft). 6 to 9 in. An improved form. White. April and May. One of the best for bordering or rock-garden use

LAVANDULA VERA (Lavender). The Lavender bears those familiar fragrant spikes of flowers so useful for the linen closet. Gray, evergreen foliage.

All Perennials, unless otherwise noted, 25c each. Six of the same variety, $\$ 1.50$.

\section{LILY.}

Swaying their graceful heads in midsummer, filling the air with fragrance and producing wonderful effects, the charming American and Japanese Lilies fill a distinct place in the hardy garden of today.

We predict they will be far more popular in a few years, when they become better known, although thousands are now planted every year.

In solid beds the effect is gorgeous. They occupy small space and thrive in a semi-shaded situation. Among shrubs or rhododendrons. they raise their heads above the other plants and flower in all their glory.

AURATUM (Fnld-banded Lily of Japan). Pure white with gold band. Huge flowers. 40e each.

CANDIDUM (Madonna Lily). The fine old Annunciation Lily with tall stems of fragrant, pure white. Tall. Very hardy and lasting, $40 \mathrm{c}$ each.

SPECIOSUM Magnificum. Bright, rich red; 40e eack.

Album. (White Japanese Lily). All the Speciosums are lovely; flowers on branching stems, gracefully suspencled. $40 \mathrm{e}$ each.
IRIS.

FLAG OR FLEUR DE LIS.
It is extremely beautiful, and can be grown wlth great ease. No garden is completo without some, and to acquire the Iris habit is to assume a hobby that can be ridden to the the Iris habit is

There are several main groups as well as additlonal species, each having distinctive merits all combining to make a superb family of hardy plants, unsurpassed by any

Prices of all varieties, 3.je cach: ver d $19 \%$ \$3.50. Smaller divisions, ate each; \$2.50 per do\%.

AUREA. Rich chrome-yellow. A very fine Iris.

ADMIRAL TOGo. Thite, faintly tinged lavender. Extra fine.

DARIUS. Rich canary yellow; falls lilac margined white. ECLIPSE. Velvety claret red, shaded violet; throat markings gold.

FLORENTIN AIRA. Waxy white, tinted lilac. Early bloomer.

GRACCHUs. Crimson, reticulated white; fine early. IINNOCENCE. Deep lavender standards; white falls. MAORI IXING. Golden yellow, margined velvety maroon gold.

MIE. CIERAL. Pure white; irregular border clear blue. Tall.

PENELOPE. White, delicately veined reddish purple.

KOCHII. Rich claret purple; handsome.

REMBRAND'. Light lavender; falls deeper.

TINNAE. Deep ageratum blue.

TRAUTLIEB. The nearest pink Iris, shaded lighter at base.

IRIS LAEVIGATA FAEMPFERI-Japanese Iris.

Flower in July after the Fleur-de-Lis have long finlshed their bloom. They prefer moist situations, where they will develop flowers of great size and wonderful colors.

\section{SIBERIA N IRIS}

SIBIRICA (Siberian Iris). Just the Iris for moist situations, as are the varieties below. Foliage narrow; flowers, though small, come in abundance. Flowers rich blue. orientals. Fich reddisl purple blossoms. A splendld Iris.

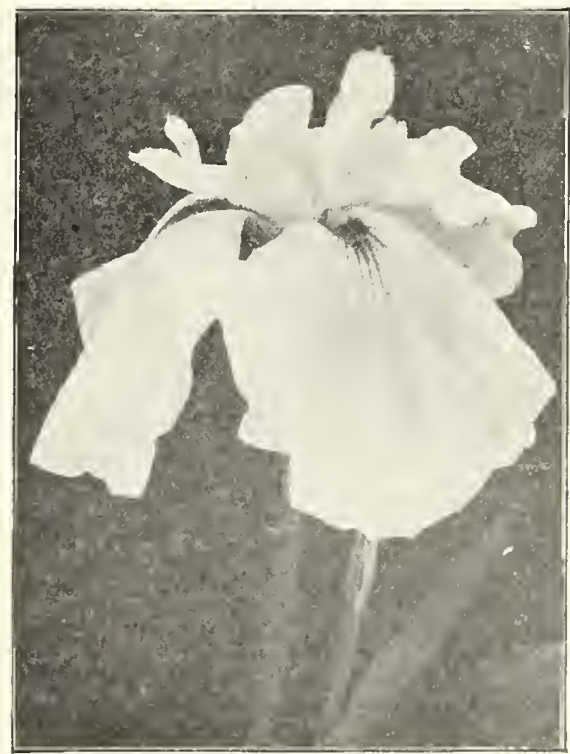

GERMAN IRIS-LA INNOCENCE. 


\section{HARDY PERENNIAL PLANTS-Cont. PAEONIES}

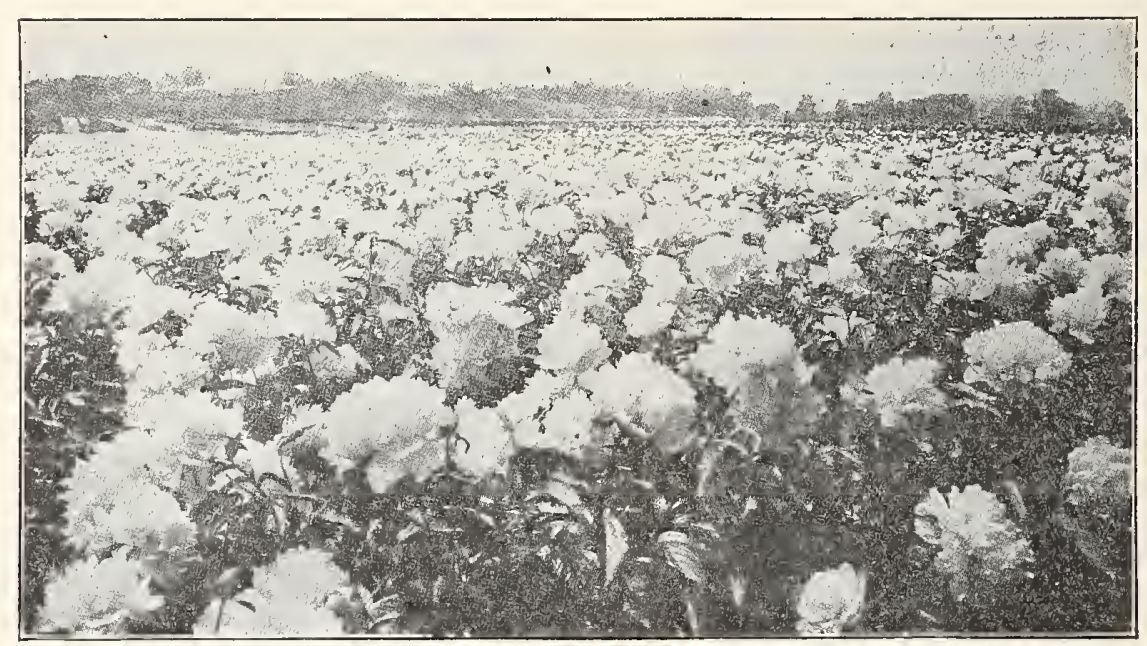

ICRES OF PALGNIES AT OUR NURSERIES

BRYSON AYRES PAEONIES-THE RUEHN OF FLOWERS.

Everyone loves the Paeony. We can all recall the enthusiasm of our grandmothers over the garden Paeony. You can imagine the raptures, if those old people were brought in contact with the splendid varieties of todlay.

Paeonies require less care after planted than any other flower, but they will respond abundantly to good care and attention.

They should be planted $3 \frac{1 / 2}{2}$ to 4 feet apart in good garden soil to 3 inches below the surface. Mulch them in the fall.

We advise August, September and October as the best time to plant them. but they can also be planted in the early spring. We sell Paeonies only of our own growing. early spring. We sell paeonies only of our own growing, stock of their own, but only buy and sell them again, with no assurance of their being true to name or quality.

ILBERT CROUSSE. Cronsse 18n. Immense convex, roseshaped flowers, fresh salmon-pink, one of the most striking. 1 yr., soe; "z-yr., tse each.

ALEXANDRE DUMAs. Guerin 186\%. Lively brilliant pink, interspersed with white, salmon and chamois. Very pretty and one of the earliest of the Chinensis sorts to bloom. 1-yr., 50e each: 2-yr., 75e each.

is A GuAy. Large semi-rose type. Pale lilac, sprinkled with minute dots of deeper lilac of medium height and habit. A very distinct variety. Late, 1-vr., \$1.00 each;

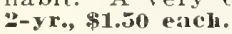

HMRON J. ROTHSCHID. Gncrin 1850. Outsicie petals rose center salmon, fragrant. I-5r., soe each: 2-yro, 75 cach: \$4.00 per dozen.

IIERNAIRD DE PAISSY Crousse 1879. Fleshy white witit glossy reflex. 1-yr., 50e each; 2-yr., Toe ench.

EDOUAIB ANDIE. Mcehin 1871. Large globular bloom; deep crimsun-red shaded black, with metallic luster on the reflex of the petals, a magnificent striking color; strong grower. Mid-season. 1-yr., Juc each: Z-yr., \$1.00 arels.

EDULIS SUPGIRA. Lemon 1s24. Pink, slightly violanceous, intermixed with narrow whitish petals. Early. 1-yr. soce ench; ?-yr., 75e ench.

Fildix CROUssle. Crousse 18s1. Large full ball-shaped bloom; brilliant red with ruby-flamed center; exceptionally bright, effective and desirable. Late mid-season. 1-yx., \$1.00 each: 2-yr., \$1.50.

FLSTIVA MAXMMA. Vielley 15.51, Enormous, very full shell-formed bloom; color snow-white shading to delicate creamy white at base of petals, with an occasional clear purple spot on edges of center petals; very fragrant. Isarly. I-yr., the each: 2-yr., \$1.00 each.
FLORAL TREASUIE. This variety has few, if any, superiors as a cut flower. It is an excellent bloomer, bearing fine, large blossoms on strong, stiff stems. Color of flowers a bright light pink. 1-yr., $\$ \mathbf{1 . 0 0}$ each: $2-y x .$, $\$ 1.50$ each.

WME. CRousse. Calot 1566. Very large, full, well-made flower; color snow-white, center petals edged with bright carmine. One of the firest. Mid-season. 1-yr., 75c: 2-yr., $\$ 1.00$ each.

MARIE LEVONNE. Lemoine 1869. Enomous sulphurwhite bloom, shaded with pink and chamois: strono stems of medium height. Magnificent variety. Very late bloomer. 1-yr., ;5e each; 2-yr., \$1.00 each.

H. JULFS GLIE. Cronsse 188s. Immense globular, very fuli, imbricated flower of very strong long stems; petalage broad and overlapping, forming the most perfect Peony in existence; color, the finest olossy flesh-pink shading to deeper rose at the base, the entire bloom covered with a silvery reflex. Mid-season. 1-5r., 75e each: 2-yr., \$1.00 each.

IRUBRA SUPERBA. Rieharison 1871. Tery large and full, dark velvety crimson, the best late dark crimson. 1 -yr., $\$ 1.00$ : 2-yr., \$1.50 each.

Thlumpll bu Nord. Deep Pink. A grand sort; extremely early, Bearis its deep pink glorious blossoms in won-
derful profusion. It is a striking variety. 1-yr., 75e; $2-y r_{4}, \$ 1.00$ eateh.

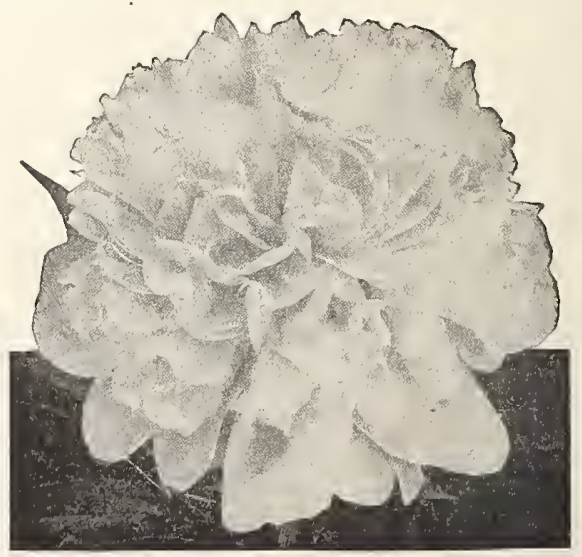

AMERICAN REAUTY PEONY

LARGE SPECIMEN PAEONY CLUMPS, EIGHT YEARS OLD, CAREFULLY BALLED AND BURLAPED, $\$ 4.00$ TO $\$ 7.00$ EACH. 


\section{HARDY PERENNIAL PLANTS-Cont. \\ PHLOX \\ pink. Futra fine (Twarf). Vely large flowering. Pure}

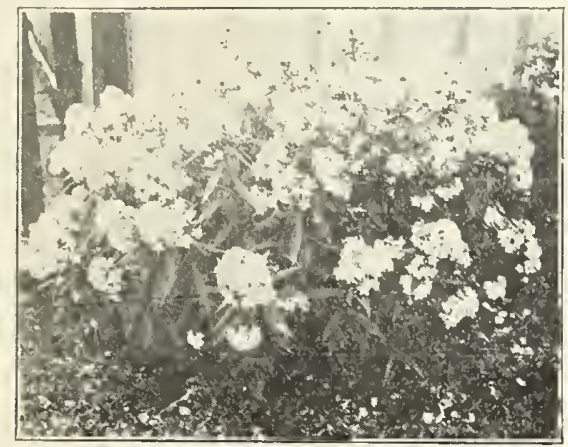

AYRES HARDY PHLOX

IIARDY GIRDEN PHLOX.

For all-round reliability the Phlox is not outdone by any othel hardy perennial.

There are varieties of the most vivid crimson, the clearest and softest shades of pink, clear mauves and purples, and snowy white. The colors are apt to deteriorate as the plants become old, but new plants should be set in to take the place of the old.

Price of Phlox, except whele otherwise noted, are anc each.

Nine coor. Flesh pink. ASTARA. Violet-purple, pure white center, petals un-
dulated.

H. COMPTE (Medium). Brilliant French-purple, with crimson camine shadings. Bse cach.

CoQUELICo'T. Fine pure scarlet. (Dwarf).

ECLAIREUR. Tall brilliant, rosy magenta, with lighter center; large flower.

LLIZABETH CAWPIELL. (Medium). Very light salmonpink, with lighter shadings and dark crimson eye. The most popular Phlox grown today. 35e each.

EUROPA (Medium). A white variety, with very decided crimson-carmine eye. se earh.

FERNAND Correz (Tall). Deep crimson with much darker center, giving bronze effect. s5e each.

GENERAI, VON HEUTSZ. Brilliant salmon. 35c each.

INDEPENDENCE (Mediun). Large, pure white.

JEANNE DE ARC (Tall. A good standard late white. 3ic esteh.

\section{PRICE OF PHLOX, EXCEPT WHERE OTHERWISE NOTED, ARE 25c EACH. EXTRA SPECIMEN}

\section{FIVE-YEAR-OLD CLUMPS, $\$ 1.00$.}

PolPl. Papaver. The Oriental Poppy with its rich crimson flowers is one of the most gorgeous of our hardy perennials.

Oricntale. Oriental Pony. Huge scarlet flowers. June $50 c$ each. 5 year old chups. $\$ 1.50$ cach.

orientale, Livermore. Blood red. June. 35e each. Large Clumps, \$1.25.

Oricutale, Royal scarlet. Intense scarlet. June. 3re cach. Iarge Clumps, \$1.25.

PHYSostegla. Obedient Plant. The long-flowering spikes of this fine plant ale fine for cutting purposes.

VIRGINICA. $2 \frac{1}{2}$ to $3 \frac{1}{2} \mathrm{ft}$. Bright pink and white. August. $35 \mathrm{c}$ each.

MIRIESI. $1 \frac{1}{\mathrm{ft}}$. Dwarf. Plue and white. June to October. 35e each.

POLYGonUn. Compactum. Grows 15 inches high; during August and September the entire plant appears as a foamy mass of white flowers; 35e each.

PRIMULA. Primiose. The English Primrose with its flowers of every color is a most pleasing border plant. A northern exposurc with shade is best. 35e each.
L. VAGU. Clear pink, vermilion center. (Dwarf.)

MME. MEURET. Flame color, carmine center. (Dwarf.)

MUE. PAIL, DUTRIE (Dwarf). A delicate, lilac-rose. reminding one of some of the beautiful soft-pink Orchids.

Mrs. WNNINs (Tall). The best tall early white for INTIEON. Brilliant caminc-rose. (Medium.)

PINK BWAUTY (Tall). An enormous spike of beautiful pale pink flowers; very fine. 35e each.

RIEINLANBElR. (Dvarf). A most beautiful salmon-pink. ith flowers and trusses of immense size; 3ic ench.

RICHARD WAIAACE. (Dwarf). White, violct-carmine IINSTROM. (Tall). A great improvement on the popular variety, Pantheon; of the same carmine-rose color as the Paul Neyron rose; Bre each.

r. P. STRUTIERS. (Tall). Salmon-pink with crimson

TIOIR. (Dwarf). A most beautiful and lively shade of deep salmon-pink, suffused and overlaid with a scarlet glow; 3ic cach.

'TO Y.STOI. (Tall). Coppery amaranth, carmine red reflex and blood-led center"; 3 inc careh.

WATER GIROIN. Fine tall salmon-pink; flowers profusely; 35e each.

W. C. EGAN. (Medium). One of the finest Phloxes yet introduced, and while the individual flowers according to the color chart are of a delicate lilac color, illuminated y a large bright solferino eye, the color effect as whole, is a delicate, pleasing shade of soft pink; 35c cach. WM. RAMSEX. (Medium). A fine deep crimson.

IIIIOX FOR HOCKRTIES AND CARPETING

PILOX SUIULATA. Fol rockeries and carpeting. An early spring-flowering type, which, during the flowering season is a mass of bloom. An excellent plant for the rockery and border, and invaluable for carpeting the ground or covering graves.

Rosel. Pink. Clump, 35e each.

LAVENDER. Be each.

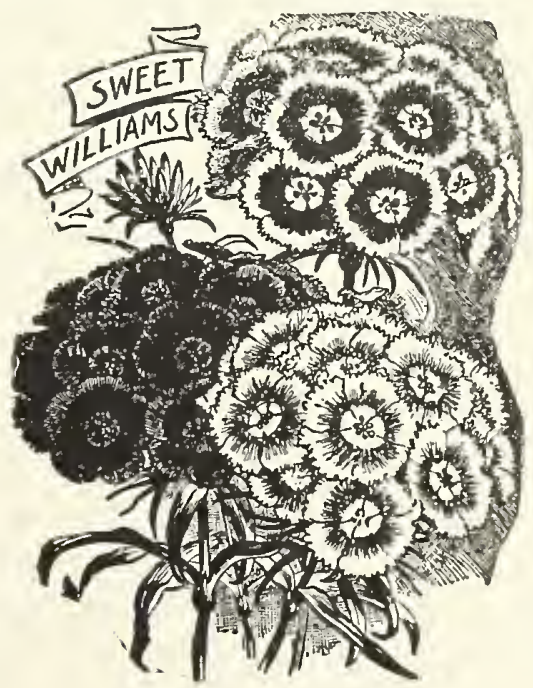




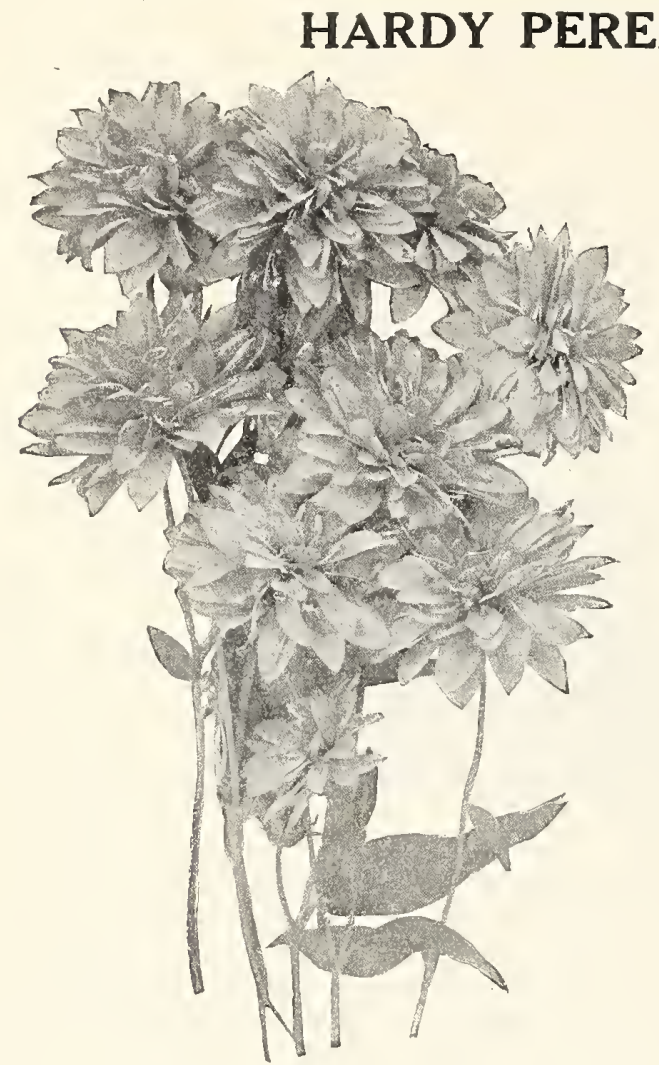

RUDHECILI OR GOLDEN GLOW
POLYANTIIA. Cowslip. 6 inches. Clusters of flowers on each stem. Various colors. April to June, 35e each.

PYREThrou. Mixed. Attractive, useful hardy plants for furnishing blossoms for bouquets. They thrive in almost any soil, and improve with age.

Rosenun. 1 to $1 \frac{1 / 2}{\mathrm{ft}}$. Very pretty daisy-like flowers. Low foliage. Flowers on good stems, Single. In shades from red and pink. June, 35e each. Extra clumps, 50e each.

RUDBEckia. Golden Glow. Tery free flowering. Showy blossoms, useful for cutting purposes. 3re each.

SALVIA. Azmea Grandiflora. Growing 2 to $2 \frac{1 / 2}{\mathrm{ft}}$, producing during August and September, sky-blue flowers in profusion; 35e each.

SWEET WILLIAI. Too well known for description. We offer these for the first time in separate colors. Salmon, red, pink, white and variegated.

TRITona. Red-hot Poker. The most curiously formed head of flowers in cultivation. Flamboyant is a very good description of the flowerheads. July to October; 50e each; \$5.00 per doz.

VERONICA. Speedwell. Veronicas are grand subjects for the hardy garden, also rock. garden. The long narrow spikes are attractive.

LONGFOLIA. SUBSESSIHS HENDRIRSONII. $1 \frac{1}{2}$, to $2 \mathrm{ft}$. A grand hardy perennial for everybody. Big blue spikes. August. 3ॅe each.

INOANA. Bright silvery foliage, with spikes of amethystblue flowers. July and August. One foot high. 35e each.

VINOA MINOR. Periwinkle or Myrtle. One of the best evergreen ground covers. Blue flowers. April and May trailing. 35e etch.
PLANTS-Cont.

VIOLETS.

VIOLETS. Sweet English. No garden is complete without the beautiful fragrant English Violets. Ours are perfectly hardy-bloom all fall and early spring. Big clump, each 20e: Extra large clumps, 35e.

VIOLA, Hardy Russia. A robust-growing variety with large, single, fragrant, deep blue flowers. 25c: Extra large clumps, soc.

YUCCA Filamentosa (Adam's Needle). Color white. A charming plant to group in the hardy flower-border. Clump, each, T5e.

\section{HARDY GRASSES.}

The common striped grass, Fulalia variegata, is very attractive and another form in which the bars run crosswise, is Eulalia zebrina. Very effective results can be secured from the hardy grasses, coming as they do in all forms and kinds of foliage.

Interspersed in the shrubbery or perennial border, they are at home. They are fine $a s$ formal beds, being unquestionably the plants that give the best all-round effect. spring, summer and fall.

Prices on all Grasses: Root-clumps, 6 in. diameter, 50e each; extra heavy elumps, töe each.

EULALIA. False Pampas. The real Pampas Grass is not hardy in the North, but the Eulalias are good substitutes and hardy.

Japonica. 6 to $8 \mathrm{ft}$. Rich, green foliage which waves with the slightest breeze.

Japoniea Gracillima Univitata. 5 to $7 \mathrm{ft}$. Narrow leaved variety of the one above, very graceful and pleasing.

Japonica Variegata. 4 to $5 \mathrm{ft}$. Striped with white variegation forming an attractive plan when grouped with the green.

Japonica Zebrima. 5 to $7 \mathrm{ft}$. Barred with bronze-yellow, and very popular, due to the bizarre effect produced.

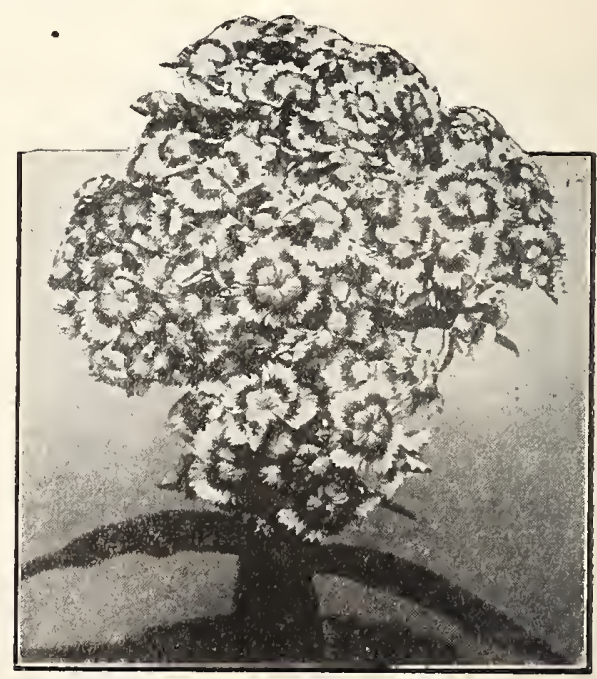

SWEE'T WILLIAM-SALMON PINK 


\section{BRYSON AYRES FAMOUS HARDY PERENNIAIS}

Plant Flowers to beautify your home grounds, to hide unsightly foundations, in borders or hedge, or in artistically arranged beds, to make your grounds radiate with their beauty and fragrance.

Peremnials have never been so popular as they are at present, and we feet that a permanent tant has bech developed which is certain to continue. Cultivation is of the simplest, beginning with any good soil for a founclation, which may bo enriched with any good tertizer, such as weh decomposed cow mangile or bone meal, deeply dug, well pulverized, in keeping the ground well stirred, and where it

A covering of manure should be applied in the fall. Tlis may be forked in to the soil early in the spring; beyond this little care need be given, the occasional staking of a plant, the cutting off of decaying flowers, which will prolong the flowering season of many species, and the dividing and replanting occasionally of sucin rarieties that hatre become too large.

PERENNIAL CLASSIFICATION LIST

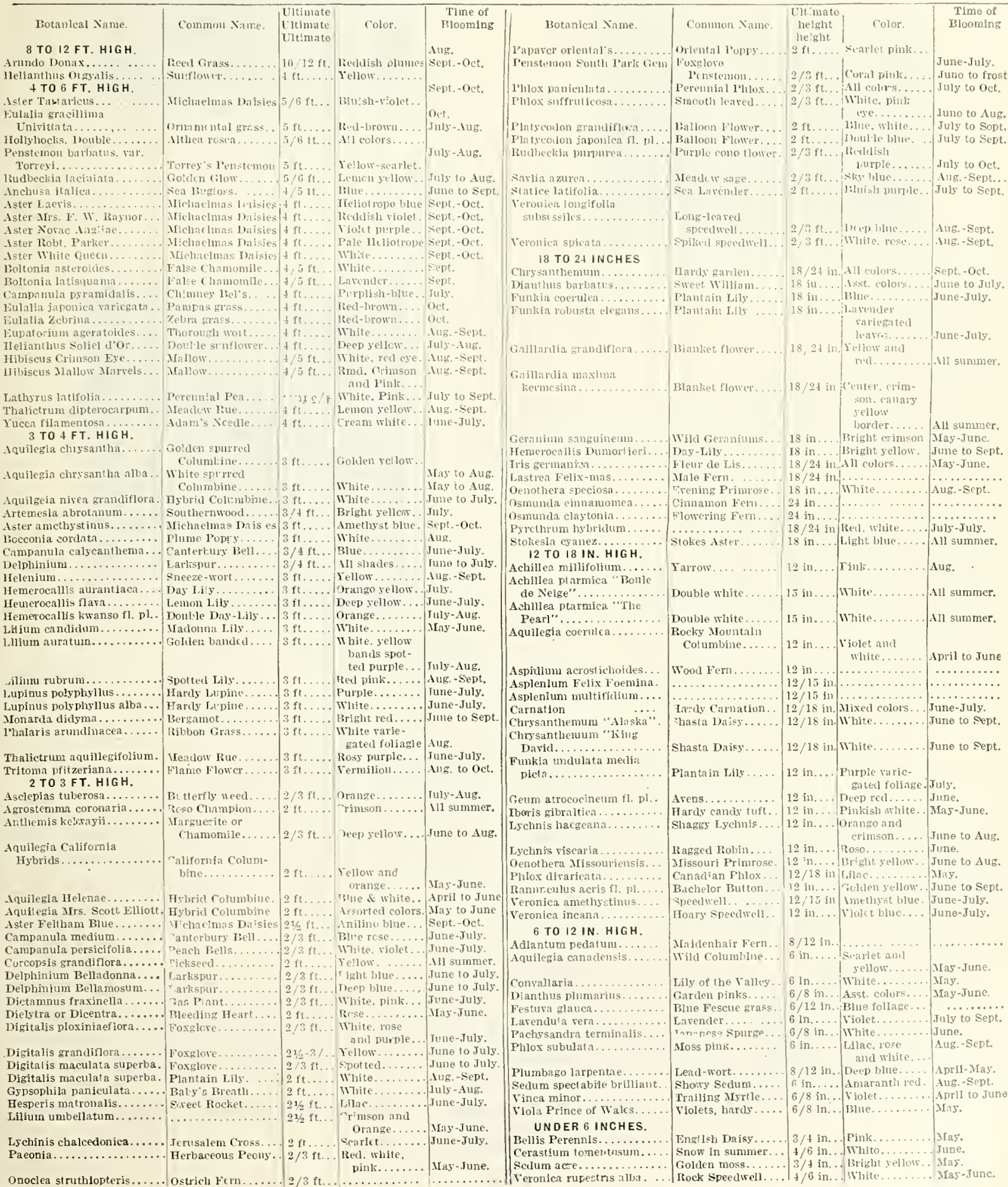




\section{CLIMBING VINES AND CREEPERS}

Climbing Vines are just as necessary in the beautifying of grounds as shrubs, trees or grass; they have their im portant part in the planting of every place.

Around new buildings, they give shade quickly and are very cooling and cheerful. For verandas or trellises, ther is nothing that adds more beauty than a proper selection of vines and, by covering summer-houses, or trunks of
dead trees, a strikingly wild, naturalistic effect is seculed

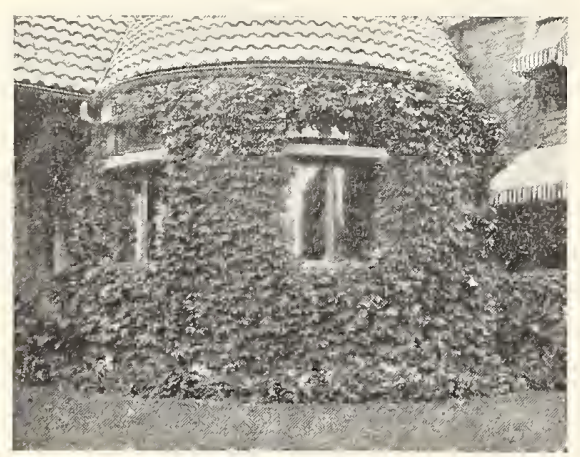

BOSTON IVY

AMPELOPSIS WNGLIMANNI (Engelmann's IVy). This is perfectly hardy in Missouri and will cling to brick, stone or stucco.

Quinquefolia. (Virginia Creeper).

Veitchii, (Boston Ivy). Very fire. Will cling to brick, ne or stueco.

MIHNONIA RIDICANS (Scarlet Trumpet Vine).

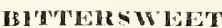

CLLASTIL ORHACLACS (Japanese Bittersweet). Almost an Evergreen Vine, as leaves and beautiful orange colored herries hang on until late in winter. Always free from insects and disease. Blossoms in June.

\section{CLEVATIS}

ChEMATIS, COCCINEA (Scarlet Clematis).

Duchess of Wdiulburgh.

Henryi. Single white.

Jackmani. Large single purple.

Madame Edonard Andre. Large single red.

Paniculat. Pure white in clusters. 2 yrs, old, tec each.

NOTE-We guarantee Clematis to reach our customers in good condition but we cannot agree to replace if they fail to grow.

ALL FLOWERING VINES LISTED ARE OVER

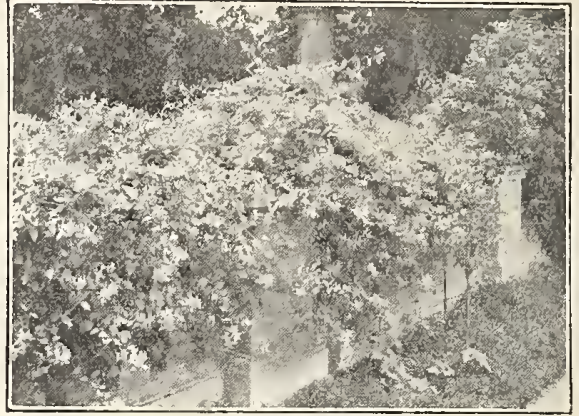

STVEET HONEYSUCKLE

WUTCHUA'S PI'P (A ristolochia Sipho).

HONISSUCKLE. II:Il's Japa!. (Lonicera Halliana.) 2 yrs. old. Fic each.

Senrlet Trimmet. (Lonicera sempervirens), 2 yrs, old. T5e each.

VITIS, Ox II RDY WILD GIRAPE.

Heta. (Grape).

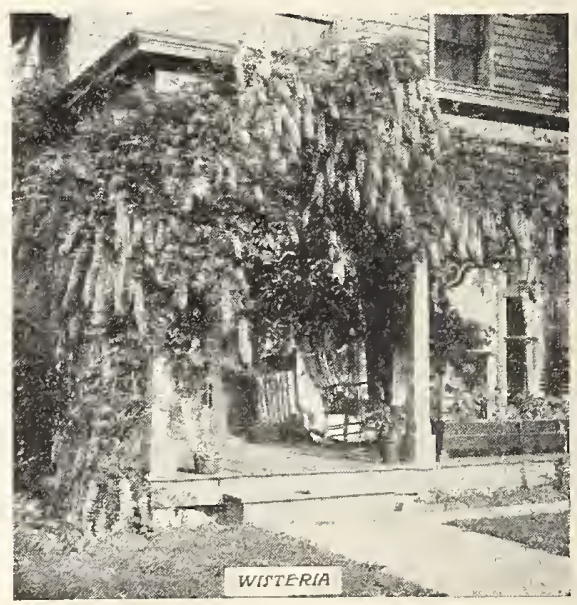

WISTARI CHINGNSIs (Chinese Purple Wistaria). IVIST R C CHNENSIS ALIA (Chinese White Wistaria). NOTED, YOUR CHOICE, EACH, \$1.00. IVIES, 50c EACH.

\section{SIX LEADING PERENNIALS}

We list herewith six Hardy Perennials in extra specimen size clumps that will bloom profusely this coming season. In case you want immediate effect in your hardy garden, be sure and try a few.

ORIENTAL POPPY - Gorgeous orange red; blossoms as large as a saucer. Extra specimen size clumps, each $\$ 1.25$.

GYPSOPHILA PANICULATA-Beautiful pure white. Lasts nearly all summer and is wonderful dried for winter boquets. Extra specimen size, each 50c.

ANCHUSA DROPMORE-Rich gention blue. A most vigorous grower. Extra specimen size clumps, each $75 \mathrm{c}$.

EVERBLOOMING JAPANESE CHRYSANTHEMUM-This wonderful flower should be in every home. It is truly a wonder-begins to bloom in June and continues throughout the summer and fall. Color, beautiful golden yellow. Needs no protection during the winter. Extra specimen size clumps, each 50c.

CARNATION FIRE FLAME-This beautiful Red Carnation is in bloom continually from May until late fall. Extra specimen size clumps, each 75c.

CELOSIA CHRYSANTHEFLORA AND STRAWFLOWER PLANTS READY MAY 15TH. DOZEN, $\$ 1.00$; FOUR DOZEN, \$3.50. 


\section{CREATING LANDSCAPE HARMONY}

Anyone can dig holes and plant trees; likewise, anyone can take spoonfuls of medicine. If the latter happens to be the wrong kind and taken in wrong proportions, comfort and physical harmony are disturbed. If trees and plants are put into the ground at random, without a preconceived idea as to final effects, there will be a disturbing of landscape harmony that will become more serious as the planting grows.

Where planting is to be done, it is the part of wisdom to procure expert suggestions as to plains and as to kinds of trees or plants to be used, for a knowledge of their habits, preferences, and appearances is absolutely essential in the preparation of a harmonious planting plan. Certain plants grow tall and spirelike, others short and bushy; some prefer moist soil, others dry; some are radiant masses of bloom in spring, others flaming groups of crimson foliage in autumn; some are hardy and withstand very low temperatures, others freeze very easily. Just which are which in these various categories and what ones are to be combined to secure the greatest effectiveness are matter's that may profitably be left to the landscape architect to determine. All that special knowledge is his; he can draw up plans for home grounds, vast estates. or parks, and choose such trees and plants as will create a landscape picture which, though it may not be possible to view as a whole at one time, will be found as pleasing to the eye and as replete with harmony as the smaller-scale work of the artist or of the sculptor.

\section{OUR SPECIAL SERVICE SAVES YOU TIME, MONEY AND DISAPPOINTMENT}

After year's of close per'sonal contact with our customers, we come more and more to feel that here is our opportunity to help you. Primarily we are nur'serymen, and are interested in the distribution of trees and plants of all kinds; but, for the convenience and assistance of our custotomers, we now maintain a service department, and if you have just built a new house or are planning the rearrangement of your grounds, or wish an effective grouping on any part of your grounds, you should get in touch with this department, for it includes one of the foremost landscape architects in the country as well as orchard and planting experts. Through it we can undertake the planning, the arrangement, and the actual planting itself, without trouble or worry on your part, of any site whatever, be it an estate or modest home.

Let our Landscape Department solve your planting problems fnr you. The money that you would otherwise have to give to a landscape architect may then be devoted entirely to the purchase of the finest kind of growing ornamentals without any part of it being diverted as architect's fees.

Let us get in touch with you today. We are anxious to come and talk it over with you, not through a salesman, as we do not employ them, but some member of the firm personally. We have found this to be the only way to most effectively cooperate with our customers.

Write us and we will arrange an appointment to suit your convenience. Once the outline of the work is agreed on, we will do the rest.

\section{BRYSON AYRES LANDSCAPE SERVICE Eleventh and $\mathrm{McGee}$ Sts.




\section{EVERGREENS}

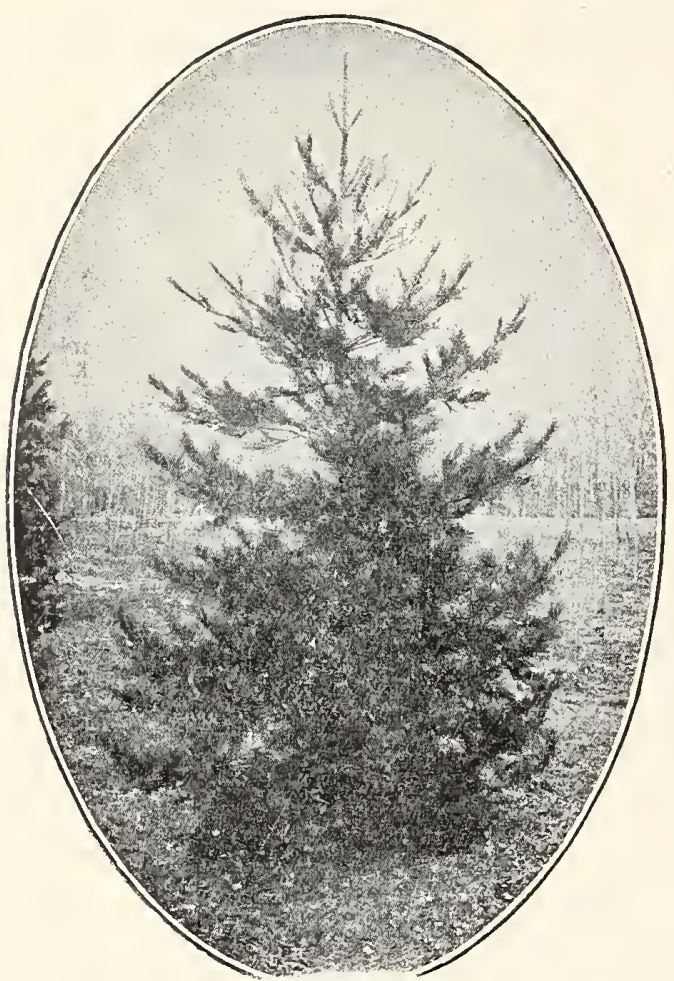

SCOTCH PINE

For your comfort, beanty, economy and value of your place, there is nothing more appropriate than Evergreens. I have heard the remarks from seemingly well meaning persons that Evergreens made them sad, reminding them of a cemetery. How ridiculous! Evergreens today are perhaps the most fashionable of all ornamental trees, and if one Evergreen ever made us feel sad, it was because some other fellow had a specimen we did not have in our nursery.

Our Evergreens are extra robust and bushy and should be in every yard By planting evergueens you will help carry out the ideal of the late President Roosevelt.

\section{EVERGREENS-}

BEST FOR LAW PLANTIN AND GROUPING.

Arbor Vital, globe.

Pinus Nimra Austriaci, (Austrian Pine.)

Pinus strobus.

Pinus Sylvereris. (Scotch Pine.)

Thuya oceidentillis.

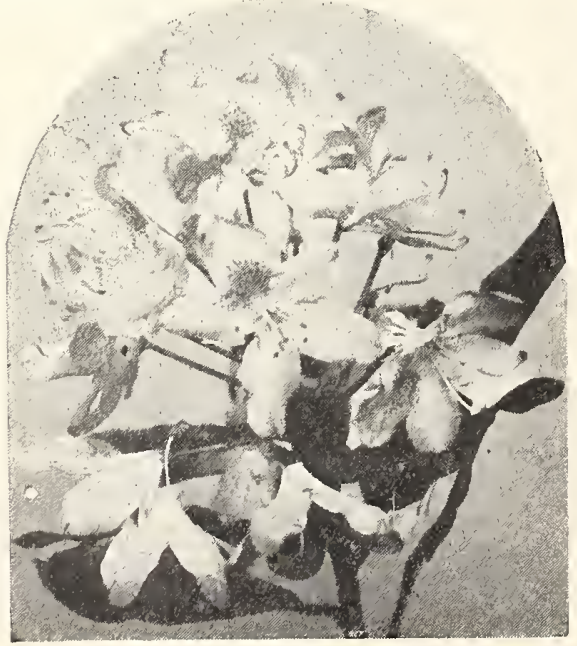

RHODODENDRON

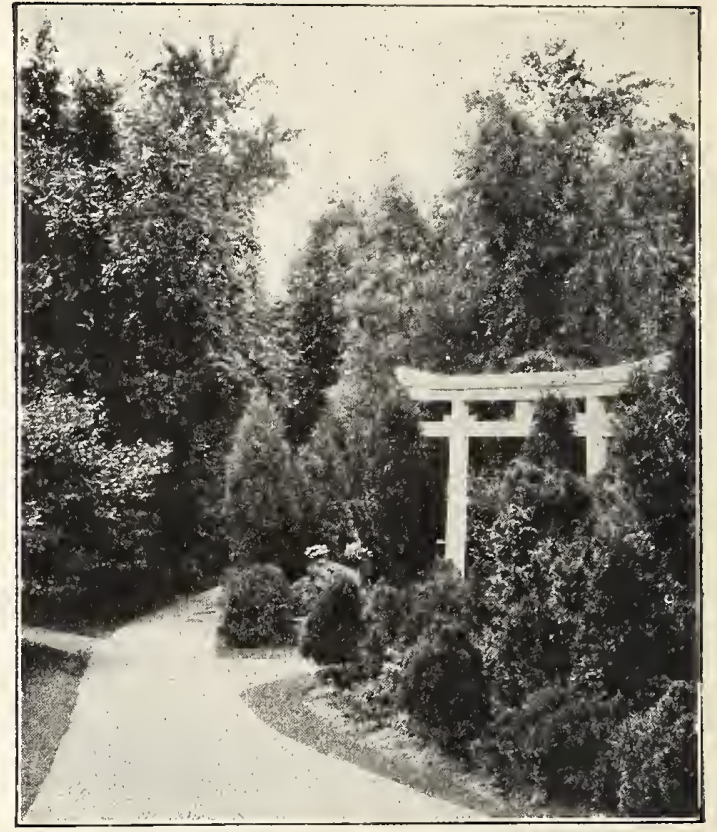

EVERGREENS, WITH GLOBE ARBOR VITEA IN FOREGROUND.

Picea Pungeus, Var. Glanea. (Colorado Blue Spruce.) Picea Douglasi. (Douglas Spruce.)

Juniperus Virginiana.

Abies Concolor. Concolor Fir.

II. Concolor. Concolor Fir. Evergreens Each tree car-

fully balled and burlaped so it retains several feet of earth 3 to $4 \mathrm{ft}, \$ 8.00$ eaeh; $5 \mathrm{ft}, \$ 10.00$ each; $6 \mathrm{ft}, \$ 15.00$ each. EUoNyMUS RADrCANS Vegtus. Beautiful Evergrten vine for planting on porches or trailing for ground cover. Thrives in shade. The contrast in winter of its beautiful red berries with its glossy green leaves makes a most striking sight. \$0.50 each; 6 for $\$ 2.75$.

\section{EVERGREEN VINES AND SHRUBS}

MAHONIA AQUIFOLIU. Beautiful Evergreen with Holly. like leaves and blue berries. In mid-winter the leaves change from a deep green to a shiry bronze red. Everyone should have this. Thrives in partial shade. Grows only about two feet high $\$ 0.75$ eacin; 6 for $\$ 4.00$.

RHODODENDRON. Large bushes \$5.00 each.

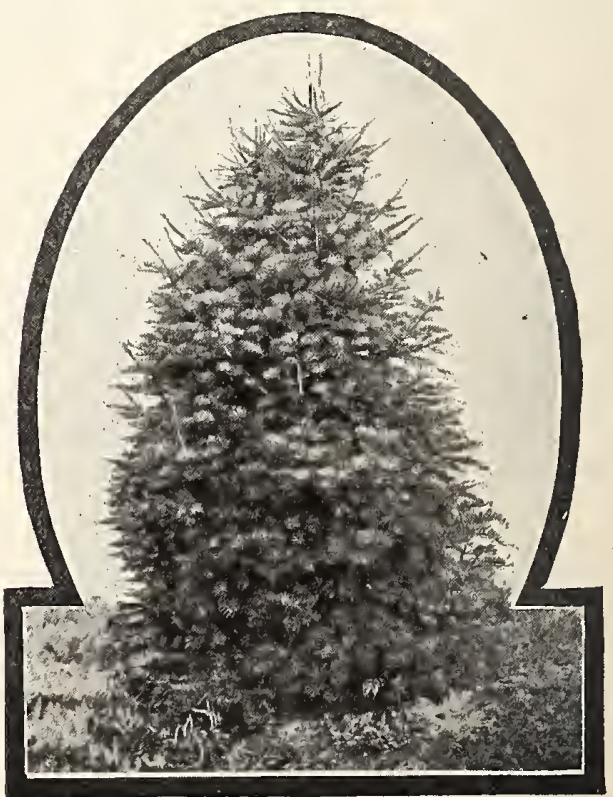

CCICCICKIIR 


\section{SHADE TREES}

If you were looking for a home, one with large Trees, Shrubbery and Flowers would appeal to you most, wouldn't it? You often hear the remark of one envious neighbor to another: "I wish I had that beautiful tree in my yard." The Bryson Ayres Service has made it possible for you to have the kind of Tree you want in your yard. You do not have to wait years for them to grow, either. Our Trees are moved with the greatest of care.

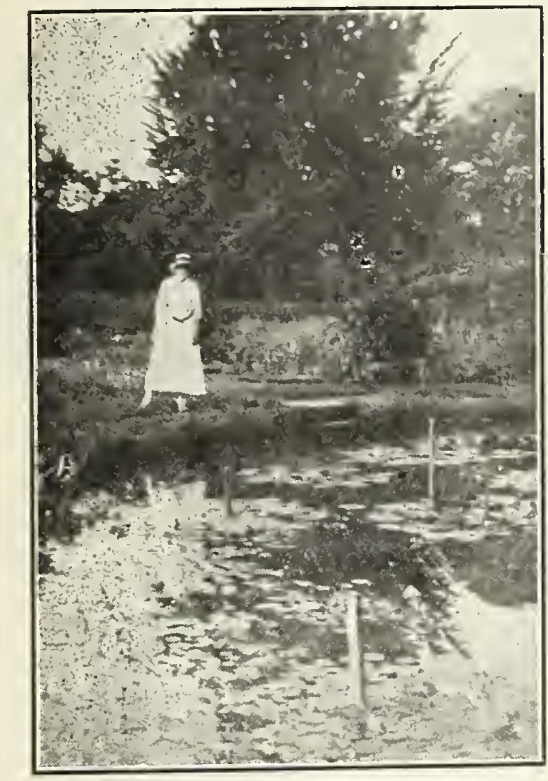

A Corner at Harvard Botanical Gardens. Cambridge, llass.

MAPLE.

ACER SACCHARINUM. (Sugar Maple.) This beautiful tree will thrive in any soil. For shade, for beauty and satisfactiun, and for real permanent worth in all landscape planting there are no other trees in its class. 8 to $10 \mathrm{ft}$. $11 / 4$ to $11 / 2$ in cal. \$2.25; 10 to $12 \mathrm{ft} ., 11 / 2$ to $1 \frac{3 / 4}{\mathrm{in}}$. cal. $\$ 2.60 ; 12$ to $14 \mathrm{ft} ., 13 / 4$ to 2 in. cal., $\$ 300 ; 14$ to $16 \mathrm{ft} . .2$ to $2 \frac{1 / 2}{}$ in. cal., \$4.00; 14 to $16 \mathrm{ft} ., 21 / 2$ to 3 in. cal., \$5.00; larger specimens, \$8.00 to $\$ 25.00$.

\section{BIRCH.}

BIRCH (Cut-leaf Weeping Birch). A most graceful tree with finely cut foliage. 5 to $6 \mathrm{ft}$., $\$ 2.50 ; 6$ to $8 \mathrm{ft}$.. $\$ 3.50$ BIRCH PAPYIFERA. Pure white bark is the attraction of this tree. It will develop into a large, shapely tree, with good foliage. The best of all white Birches, contrasting beautifully with surrounding plants, especially evergreens. 4 to $5 \mathrm{ft}$., \$1.50; 5 to $6 \mathrm{ft}$., $\$ 2.50 ; 6$ to $8 \mathrm{ft}$. \$3.50.

\section{CERCIS-RED BUD.}

C. canadensis. (American Judas). M-A small tree of Irregular rounded form, with pretty foliage, and very showy when in bloom: the branches and twigs are covered with a donse mass of beautiful pink flowers before the leaves expand.

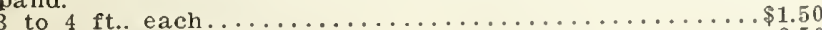

4 to 5 ft. each Specimen Tree $\$ 3.00$ to $\$ 10.00$ Each.

\section{CATALPA.}

CATALPA (Umbrelia Tree). The large, tropical-appearing leaves and rapid growth make the Catalpa very desirable C. Bungel (Globe-Headed Chinese Catalpa). 7 to $10 \mathrm{ft}$ The dense, well formed, round head, on a straight stem abou $5 \mathrm{ft}$. high, makes this an admirable tree for formal planting. 5 to $7 \mathrm{ft}$. Stems, $11 / 2$ to $2 \mathrm{ft}$. head, $\$ 3.50 ; 5$ to $7 \mathrm{ft}$. stems, 2 to larger specimens, \$7.50 to \$15.00.

\section{ELM-ULMUS}

Ulmus Americana (American Elm). Our native Elm is too well known to need description. Just the tree for quick growth and is unsurpassed for city and suburb planting. either as a street or specimen tree. None more graceful. 8 to $10 \mathrm{ft}$., $1 \frac{1 / 4}{4}$ to $1 \frac{1}{2}$ in., $\$ 2.00 ; 10$ to $12 \mathrm{ft} ., 11 / 2$ to 2 in., $\$ 3.00$ 12 to $14 \mathrm{ft} .2_{2}$ to $21 / 2$ In., $\$ 4.00 ; 14$ to $16 \mathrm{ft}$., $2 \frac{1 / 2}{2}$ to $3 \mathrm{ft}$., $\$ 6.00$ larger specimens, \$10.00 to \$25.00.

\section{LINDEN-TILIA.}

A quick grower, and a good shade tree. Fine for street or iawn use. The flowers are very numerous and deliciously fragrant, scerting the surrounding air.

T. Americana. (American Linden or Basswood.) 50 to $60 \mathrm{ft}$. An attractive, fine, large-sized tree, of rapid growth, whited for broad avenues, parks and public place

\section{- LIRIODENDRON-TULIP TREE.}

Tulip Tree. Liriodendron Tulipifera. (L). A grand native tree of rapid growth after it becomes established. A little difficult to transplant and small sizes are preferable for planting. 5 to $6 \mathrm{ft}$., each, \$2.50; 6 to $8 \mathrm{ft}$, each, \$3.50

\section{THE MULBERRY TREE-MORUS.}

II. Tartarica. (Teas Weeping Mulberry). The sweet, fleshy fruits are a great attraction to birds and should bo planted extensively. Grafted on stems about $5 \mathrm{ft}$. high. the pendulous branches completely hide the stems and sweep the ground. 5 to $6 \mathrm{ft}$., $\$ 3.50$ to $\$ 5.50$.

\section{THE POPLARS-POPULAS.}

A formal tree of pyramidal habit; very desirable for screen and wind breaks.

Carolina Poplar (Caroliniana) 10 to $12 \mathrm{ft}, 11 / 2$ to 2 in. $\$ 3.50 ; 12$ to $14 \mathrm{ft}$., 2 to $21 / 2$ in., \$4.50.

Lonilaro y Poular. F'. nigra. (fastigiata). Very decorative. Valuable for screening. 6 to $8 \mathrm{ft}$, $\$ 1.0088$ to $10 \mathrm{ft}$ $1 \frac{1 / 4}{4}$ to $1 \frac{1 / 2}{111 .,} \$ 1.5 .1 ; 10$ to $12 \mathrm{ft} ., 1 \frac{1 / 2}{2}$ to $1 \frac{1}{4}$ in., $\$ 2.50 ; 12$ to 14

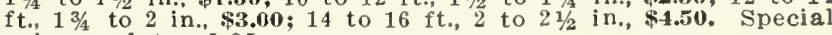
price on lots of 25 or more.

\section{FLOWERING PLUM-PRUNUS}

P. Psardi. (Purple-Leafed Plum.) Bright purple leaves that hold their color a'l summer: fine when set in the back ground in group planting. 3 to $4 \mathrm{ft}$., $\$ 2.00 ; 4$ to $6 \mathrm{ft}$., $\$ 2.50$.

P. trilolsa. (Double-Flowering Plum.) This small grow ing tree is a great favorite; the branches are completely covered with double pink flowers in May; foliage green. 2 to $3 \mathrm{ft.,} \$ 1.50 ; 3$ to 4 ft., \$2.50.

\section{MALUS-FLOWERING CRAB APPLES.}

Hardy little flowering trees that bloom abunciantly in Spring. Each year they are becoming more popular. $\mathrm{Be}$ ing of a somewhat dwarf nature adapts them for small lawns or for group planting on larger areas.

sweet Scented Crol. Malus coronaria. (S.) 4 to $5 \mathrm{ft.}$ each, $\$ 3.00$.

I. floribunda. (S.) General effect of the flower is pink. 6 to $8 \mathrm{ft}$., each, $\$ 3.50$.

Hechtel's Dounle-fowering Crab. M. ioensis, var, Bechteli. (S.) Beautiful delicate pink flowers. Double and in bud form, almost as pretty as a rose. 2 to $3 \mathrm{ft}$. , each, \$1.50; 3 to $4 \mathrm{ft}$., each, \$2.50; 4 to $5 \mathrm{ft}$., each, $\$ 3.00$.

Parkman's Floveriug Crab Applc. Malus Parkmanll. (S.) Bright rose-colored flowers. Because of the irregular growth of this particular variety it is best in groups or treated as a shrub. 3 to $4 \mathrm{ft}$., erch, $\$ 1.50 ; 4$ to $5 \mathrm{ft}$., each, $\$ 2.50 ; 5$ to $6 \mathrm{ft}$., each, \$3.00.

\section{PLANE TREE-PLATANUS.}

P. orientalis (Plane or Buttonball, The best street tree for cities. Of quick growth, spreading character, and with oceasional pruning it develops into a shapely speclmen. Prune severely when transplanted. 6 to $8 \mathrm{ft}$., \$2.001 8 to $10 \mathrm{ft}$., $1 \frac{1 / 4}{4}$ to $1 \frac{1}{2}$ in. cal., $\$ 3.00$

\section{WILD CHERRY.}

PRUNUS: WILD CHERTIES. Prunus Americana. (S.) to $5 \mathrm{ft} ., \$ 2.00 ; 6$ to $8 \mathrm{ft.,} \$ \mathbf{3 . 0 0}$; larger specimens, $\$ 8.00$ to $\$ 25.00$.

\section{REMEMBER THE BRYSON AYRES LANDSCAPE SERVICE.}




\section{LAWN GRASS SEED}

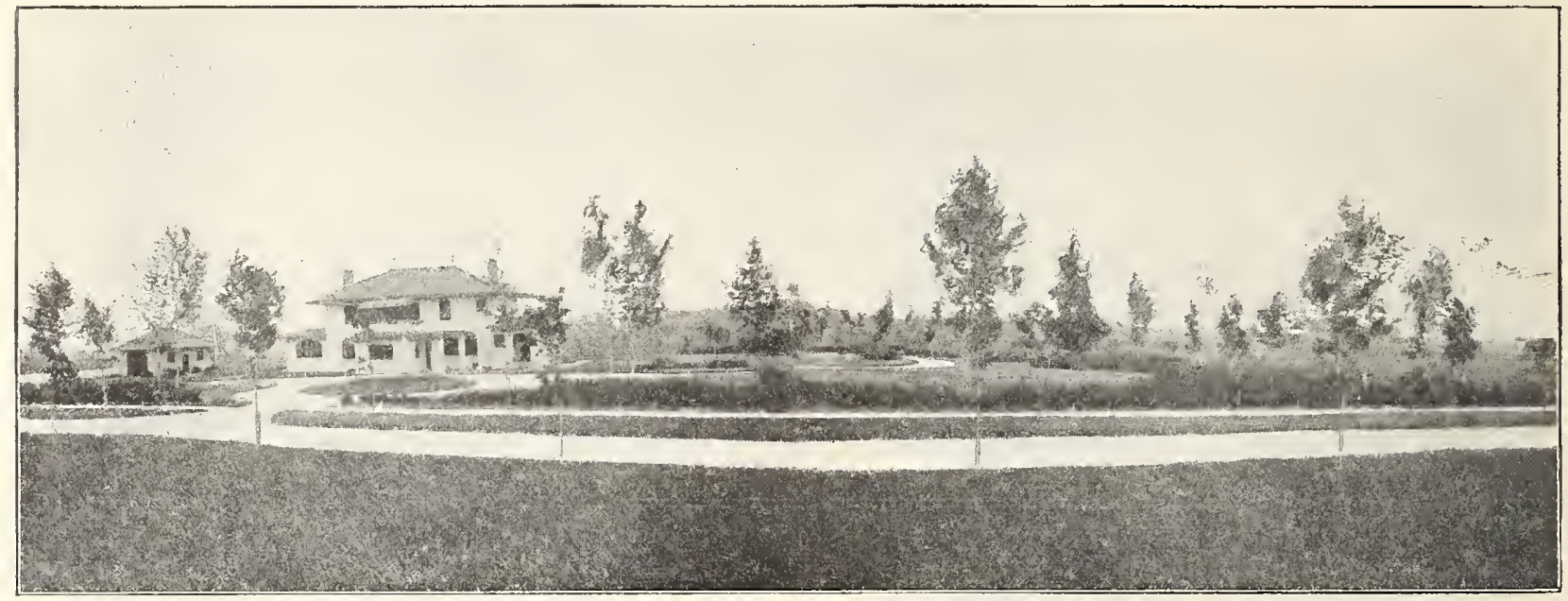

The essentials f'or a fine lawn are: First, a rich well-drained soil; second, careful preparation of the ground, making it as fine and smooth and mellow as possible; third. a wise selection of seeds; fourt?, sowing at such a time as to give the young plants a chance to become well established before being subjected to very dry or cold weather or to the direct rays of the hot summer sun. However much care is bestowed on the soil and seed, no lawn will be beautiful without freruent mowing and rolling. Too much care cannot be bestowed upon the selection of Grasses, as some varieties are the most luxuriant in spring, others in summer, others again in autumn, and a combination of the proper sorts is required for a perfect, carpet-like lawu. It may be planted early in spring $01^{\circ}$ fall, and should be sown at the rate of 60 to 100 pounds per acre. If sown in the spring, sow as early as possible, making the surface very fine and smooth, then raking it over and sowing the seed just before a rain. which, if the surface has just been raked, will cover the seed sufficiently. For fall seeding, sown before the autumn rains and early enougl to enable the young grass to become well established before very cold weather, when a light dressing of manure shouId be given.

AYRES EXTRA FINE MIXED.-We have given much thought and make many experiments to secure the best selection, and think our Ayres Mixture is the best possible for shaded lawns. One pound is the minimum quan. titl sufficient to sow 600 square feet. One lb. $50 \mathrm{c}, 10 \mathrm{lbs}$. $\$ 4.50,100$ lbs. $\$ 40.00$.

AYRES GOLF COURSE MIXTURE.-While there are on the market numerous ready-prepared Golf Mixtures of more or Iess value, we have found that the best results are obtained by giving individual attention to each customer and making a special Mixture to suit his needs. Write us a description of your links, telling what the nature of the soil is, how drained, how much it has the sun, whether the winters are long or open, and whether the summers are wet or dry, and we will offer you two or more Mixtures especially adapted to the various parts of your grounds. Write for prices.

KENTUCKY BLUE GRASS.-It has been thoroughly demonstrated that the soil of Kansas is as well adapted for raising Blue Grass as that of Kentucky. We have the facilities for harvesting and caring for the seed, and a narket for distributing it lies at our door. The seed raised here is fully equal to that raised in any other part of the country, the germinating qualities of it being above the average of the seed usually shipped in. Possessing all these natural advantages.

In connection with White Clover, Blue Grass forms the finest and closest lawn; for this purpose an extra quantity of seed should bo used-say 3 bushels of Blue Grass and 2 pounds of White Clover per acre or 1 pound for 150 feet; if sown by itself for pasture, 14 pounds is sufficient. Sow early in the spring or during the months of' September and October. One lb. 50c, 10 lbs. $\$ 4.50$.

ENGLISH BLUE GRASS OR MEADOW FESCUE.-AII points considered, this Grass must be regaraed as one of the most valuable Grasses that can be sown anywhere in this country. Its most important features are that it is drouth-resisting, frost-resisting and furnishes an abundance of pasturage early in the spring and late in the fall, when other Grasses have not come up or have died out. It is suited to a wide range of soils-does well on loany, clay, and gravelly soils, and thrives on heavy black loan, and strong and low-lying soils. In wet places in a pasture when trampled down by the stock, where Timothy, Red Clover, and Kentucky Blue Grass fail, Meadow Fescue is the only Grass that will keep these places productive, and no amount of trampling is able to destroy it. It is not adapted to light, sandy soils.

Meadow Fescue is of the greatest value if sown in connection with other Grasses; and as farmers realize the value of mixtures of perennial Grasses for pasture or meadows, the demand for Meadow Fescue will be greatly increased, mainly because it is so sure to grow and come up quickly, keeping the weeds down and furnishing forage while the weaker Grasses are getting started. Meadow Fescue inatures at the same time as Timothy and Red Top and Alsike Clover, and for meadows these varieties are often grown together. It is easily exterminated. When plowed up, it is dead for keeps. Sow 10 to 15 pounds per acre broadcast without a nurse crop. One lb., 35c; 10 lbs., $\$ 3.00$.

BERMUDA GRASS.-Peculiarly adapted to the Southern States. A delicate Grass, valuable alike for lawn and hay crop. Grows on any soil. Oklahoma Experinjent Station recommends it highly. It does well in the south part of Kansas and Southern States generally. A dry weather Grass, and is splendid to bind loose soils together. Propagate by division of the roots or sow the seed in amounts of 5 to 6 pounds to the acre. Sow from April to June. One lb. $50 \mathrm{c}, 10$ ibs. $\$ 4.50$.

WHITE CLOVER.-This is a low, close-growing Clover, with round white heads, and very fragrant; excellent for pasture, and when mixed with Kentucky Blue Grass makes the finest kind of a lawn and is universally used for this purpose in the United States. It also makes excellent pasture, and is very nutritious for sheep and cattle. It does well on almost any soil. Sow 5 to 8 pounds per ecre alone for pasture; for lawn, 1 pound to 400 square leet. One lb. 80c, 10 lbs. $\$ 7.50$.

Write for prices on larger quantities and special moix. 


\section{BRYSON AYRES}

\section{Tested and Certified Vegetable Seeds}

\section{ASPARAGUS}

If rows be 6 feet apart, 5,000 plants are required per acre.

Culture.-Asparagus is one of the first vegetables in spring, as well as one of the best grown in the garden. It is perfectly hardy, grows year aftel year from the same roots, and never fails to pro duce a crop. Asparagus does well on any well-drained soll, but the best results are obtained from rich, deep, loamy soil. Asparagus is easiy crown from seed. One ource will plant about 50 feet of row easify srow from seed blants. The seed should be planted as eariy and in the spring as the weather fecomes settled. Considerable crop vear-old p!ants.

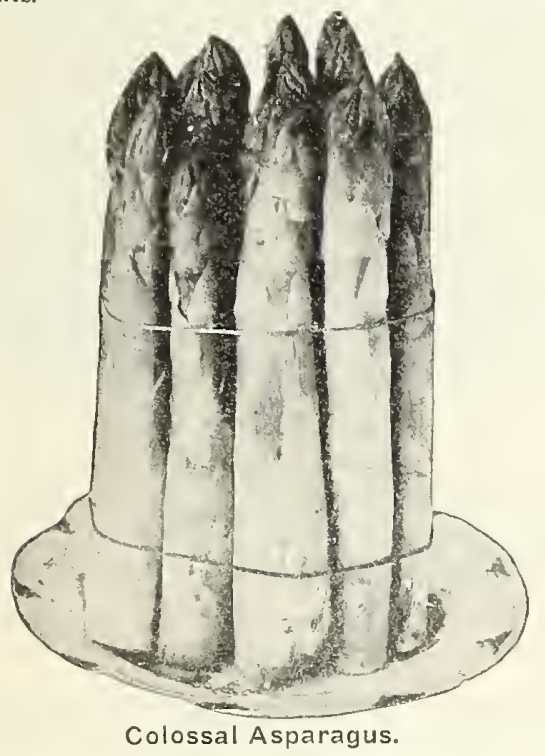

CONOVER'S COLOSSAL.-A well-known standard va. riety, rery large, strong shoots of excellent quality; not as clear white as Mammoth White, but preferred by many. Seed. price, prepair. oz., 10c; 1/4 lb., 35c; 1 lb., \$1.00; 5 lbs., $\$ 4.00$. Roots, prepaid, per $100, \$ 2.00$.

PALMETTO.-A very early maturing and prolific variety, producing an abundance of very large, deep green shoots of the best quality. 'See price prepaid, oz., 10c; 1/4 Ib., 35c; 1 lb., $\$ 1.00 ; 5$ lbs., $\$ 4.00$. Roots, price prepaid, per $100, \$ 2.00$.

Our strong two-year-old roots will give the best results: bear some first year. Doz., 40c, postpaid.

\section{BEANS}

Mature for table 30 to 50 days from germinationaccording to variety. Two bushels to the acre in drills. Order early.

Culture- TVlen all danger of spring frosts is over is the time to plant Beans. They thrive little when the soll, the days and nights are cold. Given moisture, this crop can be planted in succession until the middle of August Sandy loam is the best soil, but they grow well in any soil of average richness

Bush varieties should be plithed $1 \frac{1 / 2}{1}$ inches deep in dr.lls 18 irches or 2 feet apart, 2 inches apart in the drill. Pole varietles should be planted two or three beans in a hill, 3 feet apart each way. WVhen plants are well up thin gradually to 6 or 8 inches from wather Give them other, leaving the strongest plants not going too deep ition, mellowing the soll about them, but bear. Do not hoe when wet from dew or rain, as this infuces rust of leaves or pods. A quart will plant 100 feet of drill; 2 bushels to the acre in drills.

\section{DWARF OR BUSH BEANS}

Best Green-Podded Sorts.

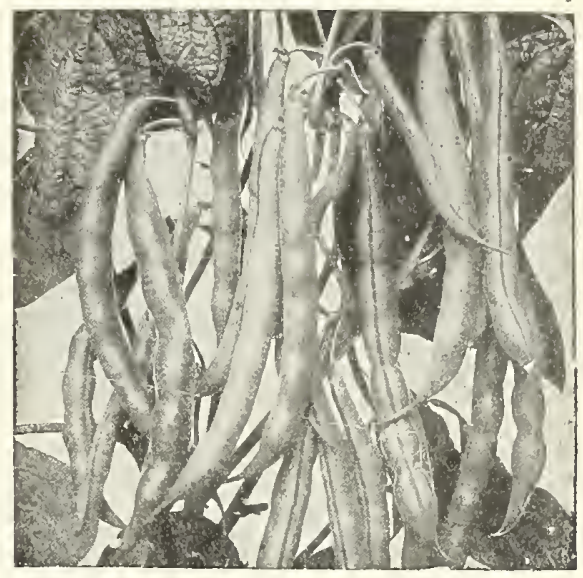

Stringless Green Pod.

BOUNTIFUL.-(31 days.) A prolific and continuous bearer. The first in spring, the last in fall. Absolutely stringless; very tender and of delicious flavor. This is a green-pod Bean and the pods are absolutely stringless, long. more or less curved. deeply creased back, sharply constrirted hetween seeds, dark green, extremely brittle, and totally without fibre. The plant is large and very erect when young, but becomes weighted down when fully developed. Because of its ahsolutely stringless, brittle, fiberless green pods is one of the most mopular varieties. Pkt., $10 \mathrm{c} ; 1 \mathrm{lb} ., 35 \mathrm{c} ; 10$ lbs., $\$ 3.00$, postpaid.

BURPEE'S STRINGLESS GREEN-POD.-(33 days.) The pods are absolutely stringless, full fleshy, crisp, very tender and of the finest flavor, remaining long in edible condition. Ready for the market two days earlier than Valentine and very prolific. Pkt., 10c; 1 lb., 35c; 10 lbs., $\$ 3.00$, postpaid.

GIANT STRINGLESS GREEN POD BEAN.-This is a great improvement on the old-time popular favorite Valen. tine Bean. The porls are fully one-third longer, averaging 5 and 6 inches in length; absolutely stringless, very crisp round, full and fleshy. It is enormously productive, its handsome pods being ready for market a few days earlier than the old Valentine. Pkt., 10c; lb., 35c, postpaid; 10 lbs., $\$ 3.00$, postpaid.

EXTRA EARLY RED VALENTINE-(35 days.) Best improved round pod strain. Pkt., 10c; 1 lb., 35c; 10 lbs., $\$ 3.00$, postpaid.

LONG YELLOW SIX WEEKS.-In many sections a popular market sort. When young, pods are of good quality. Very productive and hardy. Pods are long, straight and quite thick. Pkt., 10c; $1 \mathrm{lb} ., 35 \mathrm{c} ; 10 \mathrm{lbs} ., \$ 3.00$, postpaid.

BLACK VALENTINE.-A great improvement over the popular Red Valentine, the pods being perfectly round and straight, though not quite so early. It will withstand early and late frosts. Owing to its enormous yielding qualities and handsome appearance, it is a desirable sort for the market gardener. Pkt., 10c; 1 lb., 35c; 10 lbs., $\$ 3.00$, postpaid. 


\section{Beans, Dwarf or Bush-Cont.}

\section{BEST YELLOW-PODDED SORTS}

IMPROVED GOLDEN WAX.-(32 days.) Very early, pods are large, about 5 inches long, a golden wax color, very tender and brittle. Pkt., 10c; 1 lb., 35c; $10 \mathrm{lbs} ., \$ 2.75$, postpaid.

PROLIFIC BLACK WAX.-(33 days.) The pods are yellow, very tender, 4 to 5 inches long, transparent, and stringless. Pkt., 10c; 1 lb., 35c; 10 lbs., \$2.75, postpaid.

WARDWELL'S KIDNEY WAX.-(35 days.) This variety. maturing a little later than the Golden Wax, yields a large crop of long, nearly straight, broad, light golden sellow, handsome pods. These are of large size, about 6 inches long, and of good quality. They always command a ready sale, making the variety one of the most profitable for the market gardener. Suitable also for snaps for home garden use. The leaves are large and slightly roughened. Seed large, flattened, kidney-shaped, white, with dark markings about the eye. Pkt., 10c; 1 lb., 35c; 10 Jbs., $\$ 2.75$, postpaid.

GOLDEN EYE WAX.-Very productive; long, nearly straight; golden yellow pods; large size, fine quality; one of the best for market gardeners. Pkt., 10c; 1 lb. $35 \mathrm{c}$; $10 \mathrm{lbs} ., \$ 2.75$, postpaid.

DAVIS' WHITE WAX.-(40 days.) Very productive bearing large handsome pods, straight, 6 inches long. Pkt., 10c; $1 \mathrm{lb}$., 35c; $10 \mathrm{lbs} ., \$ 2.75$, postpaid.

CURRIE'S RUST.PROOF WAX.-Seed black; a very tine sort. Rust-proof, tender, thick-fleshed pods; early and very productive. Pkt., 10c; $1 \mathrm{lb} ., 35 \mathrm{c}$; $10 \mathrm{lbs} ., \$ 2.75$, postpaid.

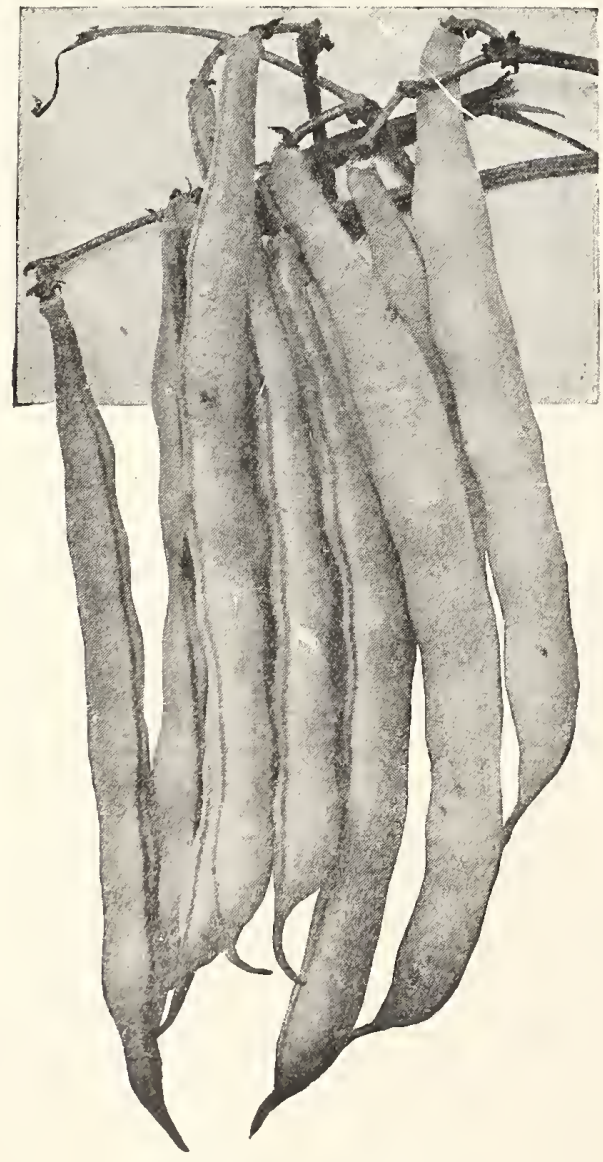

Improved Golden Wax.

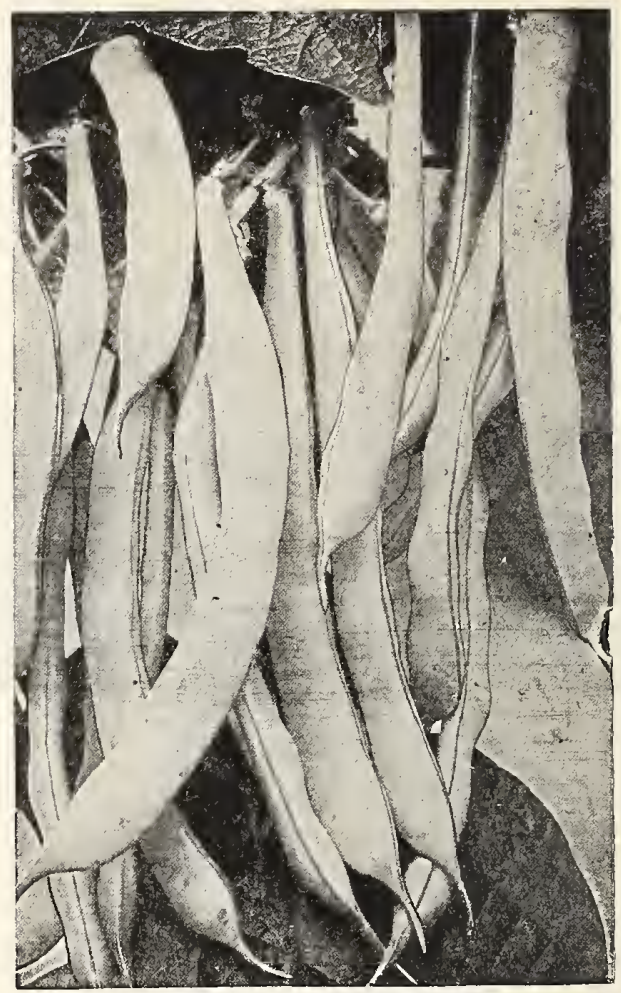

Davis' White Wax.

\section{Beans, Pole, Lima and Field Beans}

\section{POLE BEANS}

KENTUCKY WONDER.-Also known as Old Homestead. We believe this variety is the most practically use. ful of the green-podded Pole Beans, suitable for use as snaps. It is an early, very prolific sert, with showy pods of most excellent quality. The vines are vigorous, climbing well and very productive, bearing pods in large clusters. The pods are medium light green, very long. often reaching 9 to 10 inches, curved and twisted, nearly round and very crisp when young, becoming very irregular and spongy as the Beans ripen. One of the very best early Pope Snap Beans for the home garden or market. Pkt., 10c; 1 lb., $35 \mathrm{c} ; 2$ lbs., $65 \mathrm{c}$, postpair.

KENTUCKY WONDER WAX.-A yellow-podded "Kentncky Wonder." which bears a large quantity of rich, golden-yellow pods from the time the plant is about half grown until it is killed by frost in the fall. By express or freight, at purchaser's expense, pkt., 10c; 1 lb., 35c; 5 lbs., $\$ 1.50$, postpaid.

CUT SHORT OR CORNFIELD.-Green-podded Snap Pole Bean. A marvel of productiveness from July until frost. Iarge, thick, stringless pods, meaty, tender and delicious; pods green. round and long. Resembles the Kentucky Wonder, but has many superior qualities. It is larger and more prolific. Bears when scarcely higher than the average bush variety and produces continuously until frost. Absolutely stringless. Pkt., 10c; lb., 35c; 10 lbs., \$3.00, postpaid.

LAZY WIFE.-Pods are wonderfully broad and fleshy, and, above all, stringless. In many respects, they surpass anything we know of.' Then again. the pods retain their stringless and tender qualities until they are almost ripe. Pkt., 10c; 1 lb., 35c; 10 lbs., $\$ 3.00$, postpaid. 


\section{Beans, Pole Beans-Cont.}

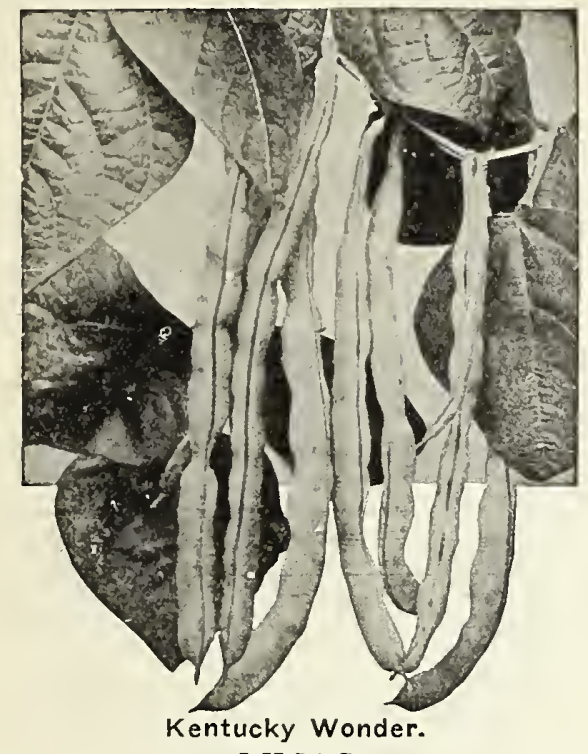

LIMAS

KING OF THE GARDEN POLE LIMA.-An improvement on the large White Lima, producing a continuous bloom and fruitable to the end of the season. Pods are of enormuus size. Pkt., 10c; $1 \mathrm{lb}$., 35c; $10 \mathrm{lbs} ., \$ 3.00$, postpaid.

HENDERSON'S BUSH LIMA.-(50 days.) Two weeks earlier than the Pole Lima, A bush strain of Sieva. Pkt. 10c; 1 lb., 35c; 10 lbs., $\$ 3.00$, postpaid.

FORDHOOK BUSH LIMA BEAN.-The only stiffly erect Bush form of the popular "Potato" Lima. Bushes of stiffly erect habit. The stalks that produce the blossoms are thrown out from the lateral and main stalks; the pods are borne in "clusters" of from four to eight.

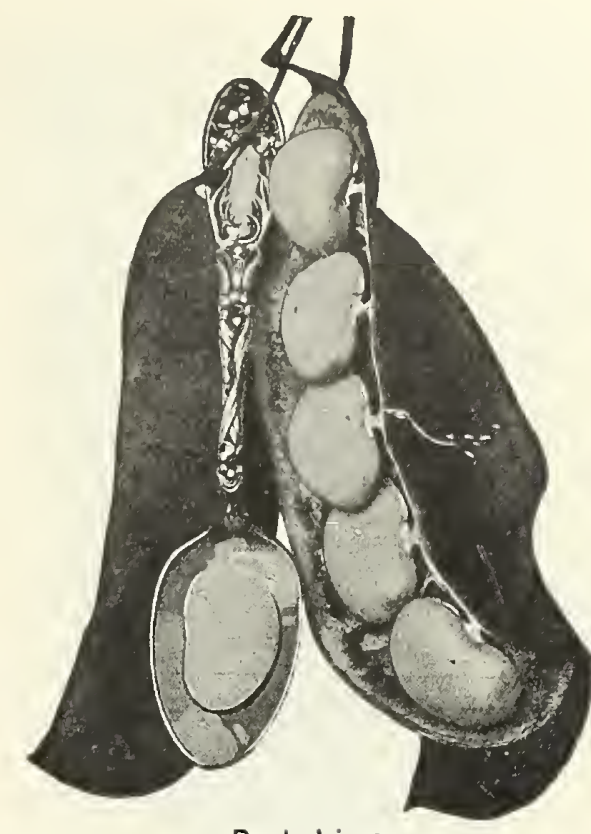

Bush Lima.

FORDHOOK is in season from four to six days earlier. The green beans even when of full size, are tender, juicy, and sweet in flavor when cooked-as distinct from the rather dry and mealy character of other varieties of the Potato Lima type. Pkt., 10c; ib., 40c; 10 lbs., $\$ 3.50$, post. paid.

BURPEE'S BUSH LIMA.-A bush form of the true large Lima. Plants uniformly dwarf, bearing very abundantly; single plants, under favorable circumstances, fielding from 150 to 350 pods containing 4 to 6 Beans; grows only 20 inches high, branching freely: immense bearer. Pkt., 10c; 1 lb., 40c; 10 lbs., $\$ 3.50$, postpaid.

\section{BEETS}

\section{GARDEN BEETS FOR TABLE USE}

\section{Crimson Gold.}

Culture.- For earliest use and market sow seed of any round sort under glass in February or Miarch, and transplant to open ground in March or April. Seed for main crop may be sown as soon as ground can be put into proper condition. For table beets, sow in drills 14 inche apart, and thin to stand 3 to 4 inches apart in the nows. Use, ounce to 100 feet of drill, and cover lightly; 6 to pounds per acre The round and turnip-sliaped beets are best for poring per acre The round and turnip-sliaped beets are best fo successional plantings and cultivate freely. Beet tops are much used for greens and frequentiy form a profitable crop with many of our market-gardener customers.

DETROIT DARK RED (Turnip-Shaped).-(45 days.) Valuahle because of its uniformity, medium in size. always smooth and free from small roots. The flesh is tender, fine-grained, and remains so long after many sorts have become wondy, early or late. Pkt., 10c; oz., 15c; 1/4 lb., 25c; 1 lb., 75c, postpaid.

CROSBY'S EGYPTIAN.--(42 days) The earliest Beet on the market. A selection from that standard market Beet, Early Egyptian, which retains the earliness of the parent stock and has added thickness. It is the deepest red, almost black in color, and is of finer quality than the Egyptian, being sweeter and even more tender and smoother. The most desirable sort for small Beets for early market. It is a very rapid grower, and can be sown outside as late as July. Pkt., 10c; oz., 15c; 1/4 lb., 25c; 1 lb., 75c, postpaid.

ECLIPSE.-(42 days.) A very early, smooth, dark, globe-shaped Beet, with small top; in earliness and quality it is excelled by none. A good cropper. We recom. mend it for market and garden use. Pkt., 10c; oz., 15c; 1/4 lb., 25c; 1 lb., $75 c$, postpaid.
CRIMSON GLOEE.-145 days.) Root of medium size, very handsome globe shape, and has a remarkably smooth surface. Both the skin and flesh are deep, rich red, fine-grained, sweet and tender in all stages of growth. Small tap root; leaves are small. Remains so long aiter many sorts have become woody. Early or late. Pkt., $10 c$; oz., $15 c$; 1/4 lb., 25c; 1 lb., $75 c$, postpaid.

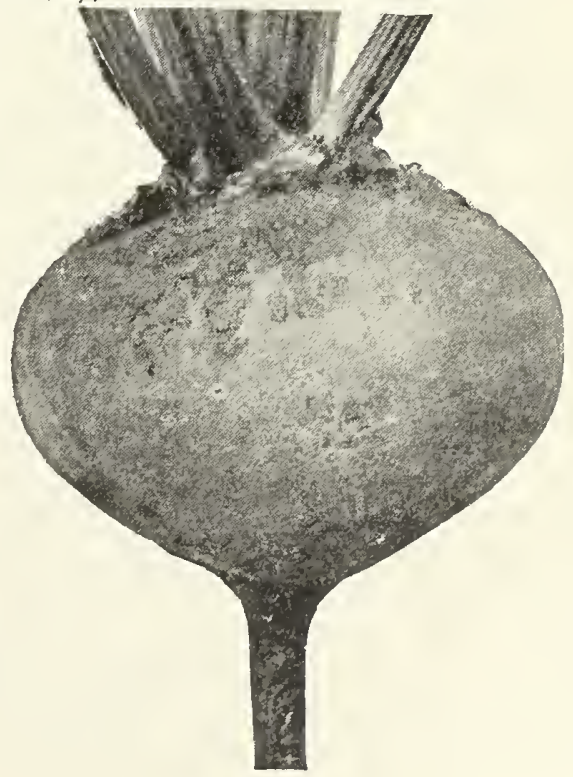




\section{GARDEN BEETS, Cont.}

THE BANQUET.-(40 days.) Dark red early Turnip Beet. A perfect out-door folcing variety, preferable to all others for first sowing; may be sown in February or sooner, if the soil can be worked. Being a rapid grower, may also be sown continuously as late as July. Handsome

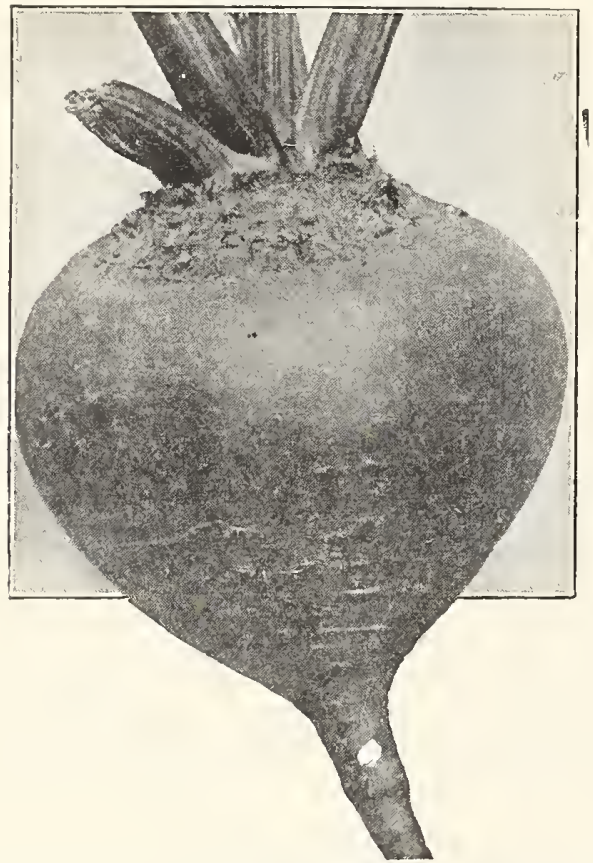

Detroit Dark Fied.

form, good size and above all, of very superior quality. Pkt., 10c; oz., 15c; 1/4 Ib., 25c; 1 lb., 75c, po'tpaid.

EARLY BLOOD TURNIP, IMPROVED.-(45 days.) One of the most popular early sorts. Smooth and dark red. Excellent quality. Pkt., 10c; oz., 15c; 1/4 lb., 25c; 1 It. $75 \mathrm{c}$, postpaid.
THE ELECTRIC.-The best second-early Beet. Thoroughbred, uniform in shape and size, with smooth, dark, red skin, small leaves and a small tap root. The flesh is fine-grained and tender; color, rich red, ringed with dark crimson. An extra fine early table Beet Pkt., 10c; oz., $15 c ; 1 / 4$ Ib., 25c; 1 lb., 75 c, postpaid.

\section{MANGEL AND SUGAR BEETS}

Culture.-Sow in the early spring as soon as ground can be gotien in proper condition, in frills 2 to 3 feet apart Cover the seed with 1 inch of soil and thin to stand about 8 to 12 inches apart in the rows. Use 1 ounce to 100 feet of drill, 5 to 6 pounds per acre. A light loamy soil is best Cultivate frequently. Keep free from iweeds

LONG RED.-A large, long variety grown for stock feeding. It stands up well above the surface; color light red; flesh white and rose colored. Oz., 10c; 1/4 lb., 20c; 1 Ib., 60 c, postpaid.

GOLDEN TANKARD.-Shape cylindrical, color deep yellow, flesll yellow circled with white. Unequaled for feeding stock. Oz., 10c; 1/4 Ib., 20c; 1 lb., 60c, postpaid.

VILMORIN'S IMPROVED SUGAR. - (85 days.) A variety originating in France. It differs from the Mangel Wurzel in containing the largest percentage of sugar of any known variety. In size it is medium, yielding from 10 to 16 tons per acre, containing about 18 per cent sugar. Should be grown in deep soil. Oz., 15c; 1/4 Ib., 30c; 1 Ib., 95c, postpajd.

MAMMOTH GOLDEN GIANT.-(85 days.) An improvement on the Long Yellow Mangel, being of greater size, more than halt above ground, and of a russet yellow color. Remarkably even in shape, rather elongated, of vigorous growth. Fine neck and a very smooth skin. Flesh white, firm and sweet, much liked by cattle. A magnificent root, easily lifted from the ground, producing enormous crops; 40 to 60 tons per acle. Relished by milch cows and sheep. Oz., 10c; I/4 lb., 20c; 1 lb., $60 \mathrm{c}$, postpaid.

RED GLOBE.-( $\$ 5$ days.) A large. globular, red sort; a better keeper than the Long Red. Produces fine crops on shallow soil; its fine grain and excellent keeping qualities render it most desirable. Oz., 10c; $1 / 4$ Ib., 20c; 1 Ib., $60 \mathrm{c}$, postpaid.

KLEIN WANZLEBEN SUGAR.-Planted for its sugarproducing qualities. Eighteen tons of sugar have been made from 100 tons of these Beets. Recommended as a winter' food for milch cows.: Oz., 15c; 1/4 lb., 25c; $1 \mathrm{lb} ., 75 \mathrm{c}$, postpaid.

\section{CABBAGE}

GARDENERS CAN RELY UPON AYRES' CABBAGE SEED. IMPORTED FROM DENMARK AND THE FINEST STRAINS OSTAINABLE.

Sow 1 ounce for 3,000 to 4,000 plants; 4 ounces for one acre.

Culture.-For plants of the earlier sorts, sow seed in January or February under glass and set out in flats or frames about 2 inçhes apart each way. Transplant to open ground as soon in spring as the land can be properly prepared. A rich, warm fibrous loam is best. Have the plants in the rows 20 to 24 inches apart and the lows at least 2 feet apart. Give thorough cultivation and irrigate worm. maggot and grecn worm, dusting with tobacco dust, insect

HOLLAND CABBAGE.-(65 days.) Extreme size, earliness, handsome color, solidity, tender fiber, fine fla or; superior for cooking, for kraut, or for p^ofitable marliet. Pkt., 10c; oz., 35c; 1/4 lb., 90c; 1 lb., \$3.00, postpaid.

EARLY SUMMER.-Second carly, somewhat flattened: valuable for home gard $n$ and takes well on market. Also well adapted for kraut. Plants are vigorous and strong growing. compact, with numerous, but not large, rather spreading, outer leaves which are somewhat frilled and sometimes rather thin and slightly undulating. Stem is rather short. Heads medium size, round, somewhat flattened, and keep longer without bursting than most early sorts. Pkt., 10c; oz., 35c; 1/4 lb., 90c; 1 lb., \$3.00, postpail

EXTRA EARLY JERSEY WAKEFIELD.-(70 days $)$ Select stock. Long recognized as the best very early marketable Cabbage. Medium size; in shape, pyramidal, with a pointed perk. Is a reliable, certain header, and one of the most profitable Cabbages for the market gardener. Our strain of seed is of superior quality. Pkt., 10c; oz., $25 c$; $1 / 4$ Ib., 90c; Ib., $\$ 2.50$, postpaid.
EARLY FLAT DUTCH.-(75 days.) A good secondearly and sure header. Tender and fine-grained. Pkt., 10c; oz., 25c; 1/4 lb., 85c: 1 lb., $\$ 3.00$, postpaid.

EARLY WINNINGSTADT.- (75 days.) An excellent variety. Heads hard, conical in shape, and a good keeper. Pkt., 10c; oz., 35c; I/4 lb., $\$ 1.00$; lb., $\$ 3.00$, postpaid.

ALL SEASONS.-( 80 days.) Large heads; very desirable for early spring, summer or fall use; good keeper. Pkt., 10c; oz., 35c; 1/4 lb., \$1.00, postpaid.

SURE HEAD.-(85 (lays.) It never fails to make a fine. solid, large head. Pkt., 10c; oz., 35c; 1/4 lb., \$1.00, postpaid.

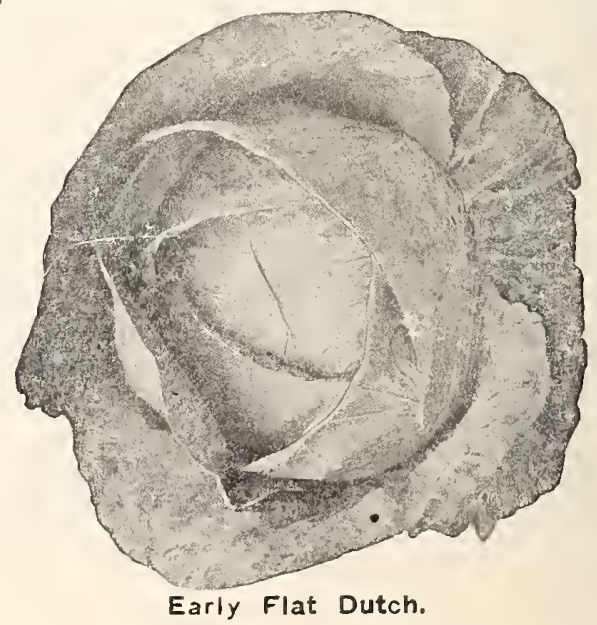




\section{CABBAGE-Cont.}

IMPROVED LATE FLAT DUTCH.-In this superior strain of late Cabbage we liave combined every good quality essential to perfection. The result of several years' selection of seed stocks of the most perfect and largest heads, with low stalks, especially those that show greater earliness in heading, with few outer leaves and very uniform color. By sucl selection we have a highly improved strain. Market gardeners grow it in preference to all others for a main crop. It is uniform in shape, size and color. Pkt., 10c; oz., 35c; 1/4 lb.. $\$ 1.00$, postpaid.

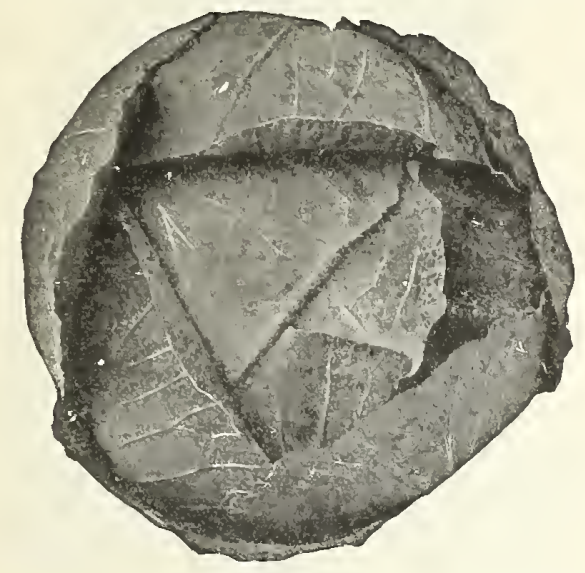

Drumhead.

AMERICAN DRUMHEAD SAVOY (Wirsing).-The leading variety of all Savoys. Valuable for the private garden. Sweeter than other Cabbages, especially when touched by a slight frost. Pkt., 10c; oz., 35c; 1/4 Ib., 90c; 1 lb., $\$ 3.00$.

RED DRUMHEAD (Improved Large Red Dutch), - The well-known standard. Heads of large size. slightly rounded, 7 to 8 inchos in diameter. Pkt., $10 \mathrm{c}$; oz., $35 \mathrm{c}$; $1 / 4 \mathrm{lb}$., $\$ 1.00 ; 1$ lb., $\$ 3.25$, postpaid.

COPENHAGEN MARKET.-(60 days.) Earliest round-headed Cabbage. An extra early variety, maturing same time as Jers 'y Wakefield, but produces larger heads than any other Cabbage equally as early. Heads average 10 pounds in weight, are ball-shaped, solid and firm. with a small core, and fine texture and quality. Seeds mature at the same time, so entire crop may be harvested at one time. Leaves are light green. tightly folded, permitting close planting. and has a short stem, growing close to the ground. Our stock is grown by the originator in Denmark and is earliest of our Danish Cabbages. Pkt., 10c; oz., $40 \mathrm{c} ; 1 / 4$ lb., $\$ 1.35 ; 1$ lb., $\$ 5.00$.

LARGE LATE DRUMHEAD.-Enormous heads, hardy, and especially desirable for winter. Fine shipper. Pkt., $10 c$; oz., 35c; 1/4 Ib., $\$ 1.00 ; 1$ lb., $\$ 3.00$, postpaid.

DANISH BALLHEAD.-One of the best winter sorts. Heads round and solid. Pkt., $10 \mathrm{c} ;$ oz., $35 \mathrm{c}$; $1 / 4 \mathrm{lb} ., \$ 1.00 ; 1$ lb., $\$ 3.00$, postpaid.

\section{CHINESE CABBAGE}

Culture.-Same as ordinary Heading Plant.

PET-SAI.-(Original strain.) This stock comes from China, where the purest strains are grown and from where the best results are obtained in Florida planting. This is the ORIGINAL strain of Chinese cabbage that has always given success and satisfaction. Pkt., 10c; $0 z ., 35 \mathrm{c} ; 1 / 4 \mathrm{lb}$. , $90 \mathrm{c} ; 1$ lb., $\$ 3.00$, postpaid.

\section{CARROTS}

Culture,-Carrots will do well in any good, well-ivorlsed soll. For early use, sow when the apple is in bloom in rows 15 inchas apart. when 2 inches high thin out so that plants stand out 4 inches apart in the row. For fall and winter use. sow seed from the 1st to 15 th of June. Roots may be stored in cellar or plt corered with dry sand. where they will keep fresh and solid until late In spring. Sow 1 ounce of seed to 100 feet of drill; 2 to 3 pounds to acre.

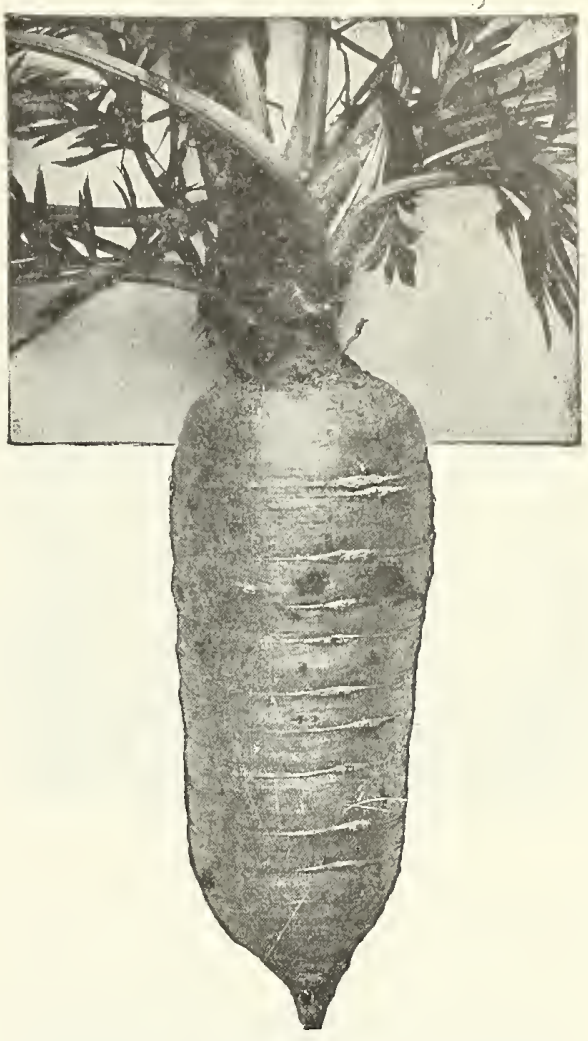

Chantenay.

CHANTENAY.- (52 days.) A smooth Carrot of perfect uniform shape. Heavy yielder, fine table quality, 5 to 6 inches long. easily dug. Flesh is of a deep yellow color, tender, excellent flavor. Pkt., 10c; oz., 15c; 1/4 lb., $35 \mathrm{c} ; 1 \mathrm{lb} ., \$ 1.00$, postpaid.

OXHEART OR GUERANDE.-(48 days.) The French Carrot is one of tie most valuable varieties, for family use or marliet. An intermediate between the half-long and the horn type. attaining a diameter of 3 to 4 inches at neck. Very productive. rich orange color, beautiful shape. Pkt., 10c; oz., 15c; 1/4 lb., 35c; 1 lb., \$1.00, postpaid.

EARLY FRENCH FORCING.-Earliest variety, largely grown for forcing purposes; globular sliaped root orange red color. Pkt., 10c; oz., 15c; 1/4 lb., 35c; 1 lb., $\$ 1.00$.

\section{STOCK-FEEDING CARROTS}

IMPROVED LONG ORANGE.-(75 days.) Old standbv for stock-feeding and table use, summer or winter. Fed to milch cows, it increases the flow of rich milk and gives 10c; oz., 15c; 1/4 lb., 35c; 1 lb., \$1.00, postpaid.

to butter a fine flavor and beautiful golden color. Pkt.,

DANVERS HALF LONG.-150 days.) Admirable in color, wonderful producer; best of all for the sto k-breeder and valuable to market gardener. With this variety planters secure the largest return to acre, with least difficulty of harvesting. Pkt., 10c; oz., 15c; 1/4 lb., 35c; 1 lb., $\$ 1.00$ postpaid.

\section{CRESS OR PEPPER GRASS}

Culture.-A refreshing salad of easiest culture. As soon as the ground can be worked in the spring sow thickly, broadcast, or in rows 8 inches apart. Repeated sowings may be made every two weeks for a sucression.

DWARF FINE CURLED.-A small, pungent salad of easiest culture. Seed should be sown early in rows about 15 inches apart and covered lightly; when 2 or 3 inches high it is ready for use. It is often mixed with lettuce, and imparts a warm agreeable taste to the salad. Pkt., 10c; oz., 20c, pestpaid.

TRUE WATER CRESS.-Succeeds only where the roots and stems are submerged in water. A highly prized salad of a pleasant and agreeable flavor. Should be planted wherever a suitable place can be found for it. 33 


\section{CAULIFLOWER}

Culture.-A vegetable requiring very rich suil and plenty of moisture and careful attention. Not as hardy as Cabbage in resistance to hot, dry or cold weather. Sow in hot-beds in January or February and when plants are large enough transplant. Sel plants out 15 to 18 inches apart and rows 2 feet apart. When the heads out 15 to 18 inches apart and rows 2 feet apart. When the hedds and weather. One ounce wili produce 2,000 plants.

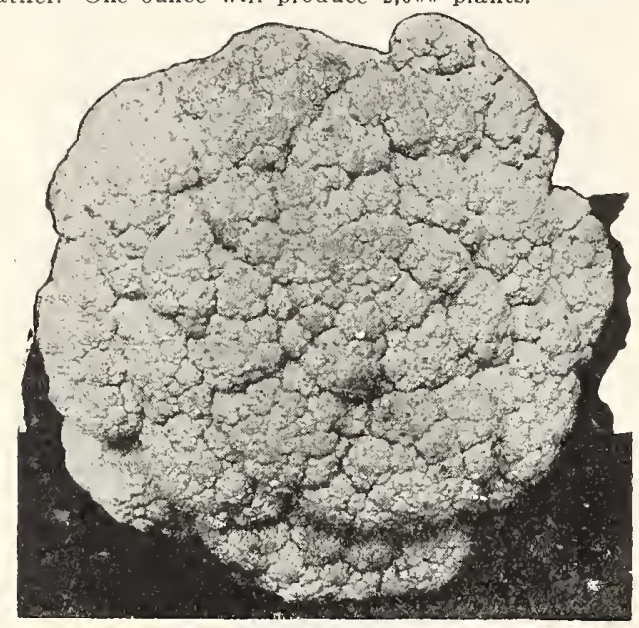

Early Snowball.

EARLY SNOWBALL.-Under favorable conditions, every plant produces a white head of fine quality. Pkt., $10 \mathrm{c} ;$ oz., $\$ 2.50$, postpaid

EXTRA SELECT DWARF EARLY ERFURT.-The best in general cultivation for forcing and open ground. Head close, compact and large. measuring from 7 to 10 inches in diameter. Plants are quite dwarf, and seldom fail to form a good sized symmetrical head of flower. Pkt.y $10 \mathrm{c}$; oz., $\$ 2.50$, postpaid.

\section{COLLARDS}

Oalture.-This is a tall, loose-leafed cabbage-like or kale-like plant, known in different sections as "Cole." "Colewort," or simply "Greens." It is extensively used for the table, as well as for stock feeding. Sow the seed thickly in drills, in rich ground, transplanting when about 4 inches high; or sow in drills where the plants are to

GEORGIA, SOUTHERN, OR CREOLE.-This is the white or green-stemmed variety growing 2 to 3 feet high and forming a large, loose, open head or cluster of leaves with a rather long stem. A frost, if not too severe, will improve rather than injure the quality of the leaves. Pkt., 10c; oz., 20c; 1/4 lb., 35c; 1 lb., \$1.00, postpaid.

\section{CHICORY \\ LARGE-ROOTED OR COFFEE.-Pkt. $10 \mathrm{c}$. CELERY}

Culture.-Celery seed is slow to germinate and ample time must be given. Sow thin; cover lightly. Keep constantly moist About 7,500 plants per ounce of seed, or $1 / 4$ pound per acre When seeding plants are 3 inches high they should be clipped at top to favor stocky growth, or transplanted. Celery is mostly grown under flat culture, without trenches, rows 3 to 5 feet apart. For home use it is often grown in double rows, 10 inches apart, without trenching, anked for winter storage where it grows, without lifting.

GIANT PASCAL.-Grows about 2 feet high. Stocks are broad. thick and crisp, and rich nutty flavor. Heart is golden yellow, very full and attractive in appearance; bleaches very easily and quickly. Pkt., 10c; oz., 30c; $1 / 4$ lb., 90c, pnstpaid.

GOLDEN SELF.BLANCHING.-(100 days.) A beautiful plant, of close habit, compart growth, and straight and vigorous stalks. Ribs are solid, crisp and brittle. Its flavor is surpassed by no other variety, and it has the merit of being self-blanching to a very remarkable degree. Pkt., 10c; oz., 30c; 1/4 Ib., 90c, postpaid.

WHITE PLUME.-(110 days.) Valued because stalks and portions of inner leaves and heart are white. By tying up the stalks and drawing up snil with the hoe, the work of blanching is completed. Ornamental, tender, crisp, good flavor, very early. Pkt., 10c; oz., 30c; $1 / 4$ lb., 90c. postpaid.

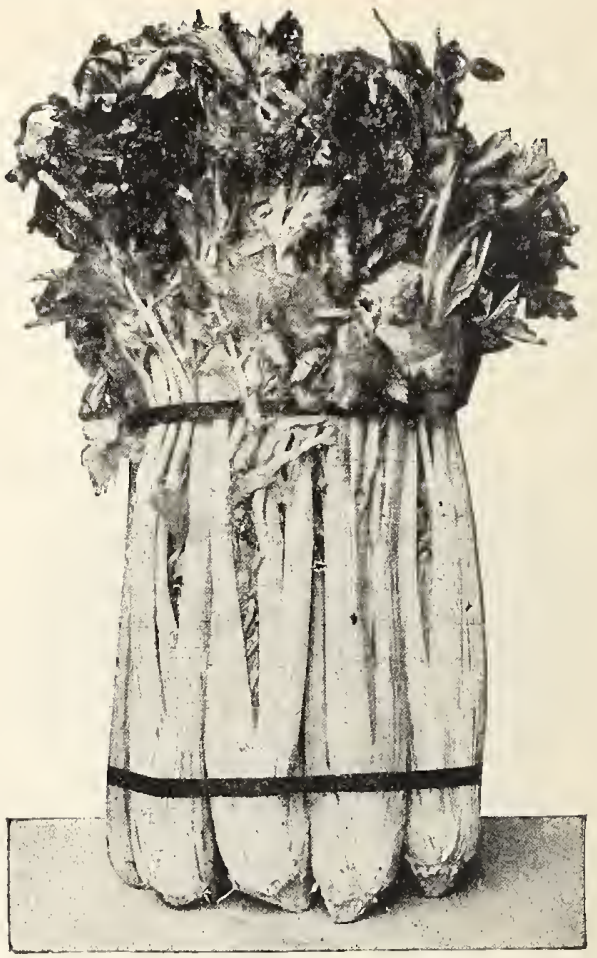

Golden Yellow Self-Blanching.

\section{CELERIAC, OR TURNIP ROOTED CELERY}

Culture.-In this kind of Celery roots have been developed by cultivation, and not the leaf-stalks. The roots, which are the edible portion, keep well for winter use and are excellent for soups and stews; also cooked and sliced as a salad.

Sow seed at same season and give same treatment as Celery. Transplant to moist, rich soil in rows 2 feet apart and 6 inches apart in row Give thorougl culture. It is not necessary to earth up or "handle" plants. After roots have attained a diameter of 2 inches they are fit for use

To keep through the winter, pack in damp earth or sand and put in cellar or leave out of doors, covering with earth and straw put in cellar or leave o

LARGE SMOOTH PRAGUE.-An improved variety of Turnip-rooted Celery. producing large roots of globular shape and smooth surface. Pkt., 10c, postpaid.

\section{CHIVES}

ALLIUM SCHOENOPRASUM.-An Onion-like plant used as salad and for flavoring soups. Makes an excellent ornamental garden bed edging which may fre quently be cut, a new growth of leaves appearing after each cutting. Plants grow about 10 inches high. One sowing will do for about three years. Pkt. $20 \mathrm{c}$.

\section{CORN SALAD}

For winter use, sow shallow in rows 1 foot apart, in August or September. Plants are ready for use in six or eight weeks. When winter approaches, lightly cover with hay or straw. Plants are hardy and will remain green and fit for use all winter. Seed mav also be sown early in spring. Pkt., 10c; oz., 40c, postpaid.

\section{CUCUMBERS}

Culture.-Flourish best in a rich, warm, sandy loam. Sow when danger of frost is over, in hills 4 or 5 feet each way. As the young plants have many enemies, sow thickly, $1 / 2$ inch deep, and then thin out finally to three or four plants to the hill. Use 1 ounce of seed to 75 hills; 2 to 3 pounds to the acre. Gather cucumbers by cutting. nut tearing. Leave none to ripen if you want a full crop. For cor the early use, plant in hils $4 \times 4$ feet, on a warmer border, when the cherry is in bloom; and for a succession, solant in the middle of when the

EARLY FRAME, OR SHORT GREEN.-(52 days.) An excellent sort for table use and for pickling. Fruit straight, handsome, smaller at each end; bright green; flesh tender and crisp; makes fine pickles. Pkt., 10c; oz., 15c; $1 / 4$ lb., 


\section{CUCUMBERS-Cont.}

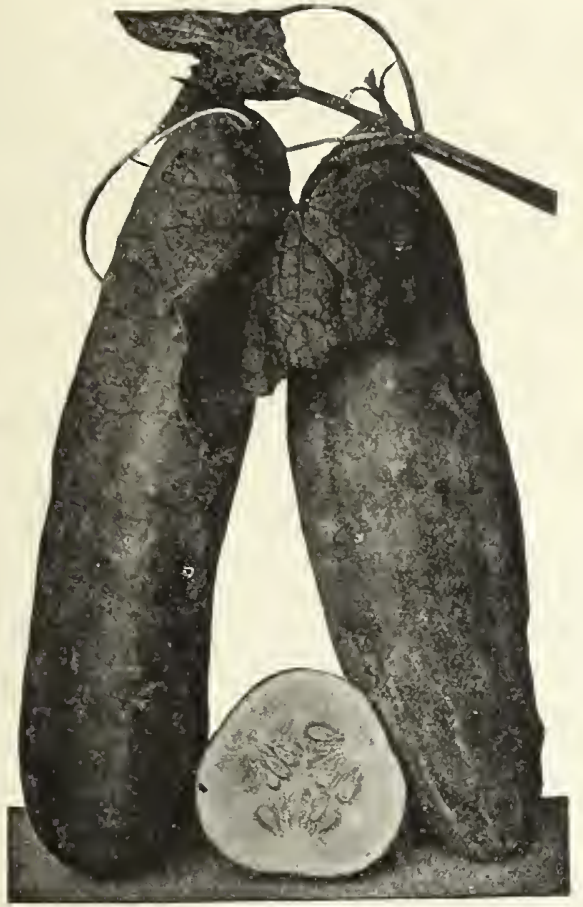

Evergreen.

DAVIS' PERFECT.-(70 days.) An early, prolific and continuous producer of large and symmetrical fruits of a deep green color, shading perfectly to ends, practically no misshapen fruits or culls. Ideal for slicing; fresh, sparkling white, refreshing. A delightful plate on the table, and flavor is new. Vines are vigorous, mildew-proof and maintain their bearing from earliest to latest season. This variety best for home or market gardeners. Pkt., 10c; oz., $15 c$; $1 / 4$ lb., 50c; 1 lb., $\$ 1.35$, postpaid.

EVERGREEN, OR EXTRA LONG WHITE SPINE.(60 days.) One of the best table sorts. A fine strain, producing smooth, regular fruits, frequently 12 inches long; smooth, round handsomely colored and very regular in size and form; of excellent quality. Pkt., 10c; oz., 15c; 1/4 lb., $45 \mathrm{c} ; 1 \mathrm{lb} ., \$ 1.35$, postpaid.

IMPROVED LONG GREEN.-(82 days.) Unquestionably the most popular general-purpose Cucumber. When matured, is 9 to 12 ichens long, very solid and crisp; retains its dark green color until nearly ripe. One of the best for small pickling, if pickled properly. Pkt., 10c; oz., $15 c ; 1 / 1$ Ib., $45 c ; 1$ lb., $\$ 1.35$. postpaid.

EXTRA EARLY GREEN PROLIFIC PICKLING.- $(54$ days.) One of the best for pickling. Dark green and of uniform size; very few seeds. Pkt., 10c; oz., 15c; $1 / 4$ lb., 45c; 1 Ib.. \$1.35. postpaid.

JAPANESE CLIMBING.-(60 days.) Can be trained upon a trellis or poles, which will insure earlier ripening and a straight handsome form. Endures summer heat and drouth exceedingly well. It is entirely distinct. Quality splendid. Adapted for pickling, as well as for slicing for salads. Cucumbers are 12 inches in length. Skin smooth, dark green, turning to brown, and pitted with ribs. Flesh is pure white, crisp and of mild flavor. Pkt., 10c; oz., 15c; 1/4 Ib., 45c; 1 lb., $\$ 1.35$, postpaid.

BOSTON OR JERSEY PICKLING.-(55 days.) A favorite Eastern sort of fine quality, medium length; reliable for pickling and slicing. Pkt., 10c; oz., 15c; 1/4 Ib., 45c; 1 lb., \$1.35, postpaid.

EARLY WHITE SPINE.-One of the best for table use. Vines are vigorous, fruiting early and abundantly. Fruits are straight, dark green, well covered with white spines, and when mature are about 7 inches in length. Flesh is crisp, tender and excellent quality. The variety is much used for home garden and market. Pkt., 10c; oz., 15c; 1/4 Ib., 45c; 1 lb., \$1.35, postpaid.
EARLY GREEN CLUSTER-(52 days.) Short and prickly; bearing in clusters; prolific; fine for bottling. Pkt., 10c; oz., 15c; 1/4 lb., 45c; 1 lb., \$1.35, postpaid.

ARLINGTON.-A madium early, white-spined Cucumber, more slender than Early White Spine and pointed at each end. The young fruits are crisp and tender. The mature fruits are bright deep green and are about 7 inches in length, sometimes longer. This variety is extensively used for the bome garden and for bulk pickles. Pkt., 10c; oz., 15c; 1/4 Ib., 45c; 1 Ib., $\$ 1.35$, postpaid.

KLONDIKE.-A medium early white-spined Cucumber of handsome, very dark green color and of excellent quality for slicing. The vines are very hardy and productive The mature fruits when grown under favorable conditions are often about 8 inches in length and are uniform in size and shape. The color is very dark green, slightly striped at the ends. The dark green color is retained much longer and is affected less by the hot sun than any other sort with which we are familiar. Its uniform size and shape and splendid color are making this variety very popular as a shipping sort. Pkt., 10c; oz., 15c; 1/4 lb., 45c; 1 lb., $\$ 1.35$, postpaid.

EARLY FORTUNE,-Strong and vigorous growth, producing abundant crops of cucumbers, which are longer than Evergreen, more cylindrical in shape and have a very dark green skin. The flesh is thick, seed cavity relatively small and the quality is excellent. Pkt., 10c; oz., 15c; 1/4 Ib., 45c; 1 lb., $\$ 1.35$, postpaid.

\section{SWEET CORN}

Write for Special Prices on Larger Quantities Than Listed. Culture.-Sweet Corn always does well on sod land, or where clover has been turned down. Plant when danger of frost is over, in hills $2 \times 3$ feet, according to variety. Give frequent and continued shallow culture. Leave two or three stalks to the hill, and make sucessional plantings until nearly mid-summer. Use 1 quart for 600 hills; 6 to 8 quarts per acre. Cover seed with 3 inches of goll.

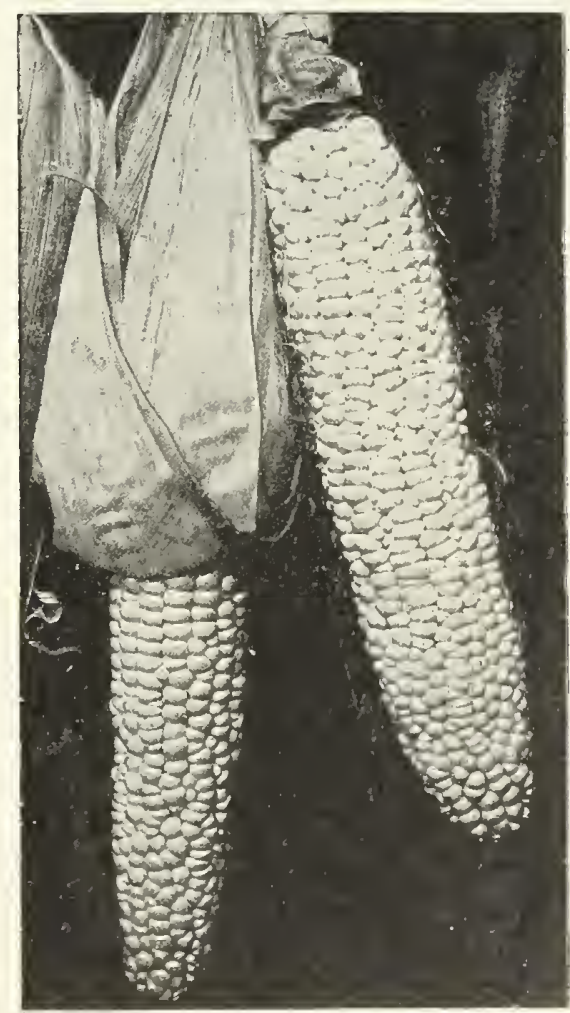

Country Gentleman.

NINE EXTRA EARLY VARIETIES

COUNTRY GENTLEMAN.-(70 days.) A shortstalked productive sort, frequetlny producing three ears to the plant. Ears large for so small a stalk; grain narrow and very deep, after the form of a shoepeg. Highly recom. mended as one of the very best. Pkt., $15 \mathrm{c} ; 1 \mathrm{lb} ., 30 \mathrm{c}$, post- 


\section{SWEET CORN-Cont.}

GOLDEN BANTAM.-(70 days.) Dwarf, 41/2 feet high, So very hardy that it can be planted earlier in the spring and in colder and damper soil than other varieties of table Corn. Exceedingly sweet, very productive, consequently a great favorite. When ready for table use, it is a creamy yellow. Growing in great demand. Pkt., 10c; 1 lb., 30c, postpaid.

EXTRA EARLY MINNESOTA.- $(60$ days. $)$ Among the extra early Sugar Corns, coming two or three days after Corey. Ears well made out. Pkt., 10c; 1 lb., 30c, postpaid.

EARLY EVERGREEN.-Like Stowell's Evergreen, only ten days earlier. Fars large, about 18 inches long, 12 to 16-rowed, and having the identical flavor of the famous Stowell's Evergreen. It remains green a remarkably long time, and the kernels retain the sweetness and tenderness which is so characteristic of Stowell's. Pkt., 10c; 1 lb., 30c, postpaid.

WHITE COREY.- $\left(62\right.$ days.) Stalks 4 to $4 \frac{1}{2}$ feet high. A valuable sort; quite robust for a short-stalked and exceptionally early sort. Ears of good length : that is, 6 to 7 inches; grains large, sweet and tender. Pkt., 10c; $1 \mathrm{lb}$, $30 c$, postpaid.

ADAMS' EARLY.-(68 days.) In order of maturity after the Extra Early Adams. Pkt., 10c; 1 lb., 30c, postpaid.

EXTRA EARLY ADAMS, OR EARLY BURLINGTON. - $(62$ days.) Height of stalk, 4 feet; ears set within 6 inches of the ground. Not a Sugar Corn, but a decided acquisition so very early in the season. Plant close in rows at $21 / 2$ feet and thin to 1 foot. Pkt., 10c; $1 \mathrm{lb} ., 30 \mathrm{c}$, postpaid.

\section{LATE VARIETIES}

STOWELL'S EVERGREEN.- $(80$ days. $)$ The most popular among the late Sugar Corns. More bushels are used than all other sorts combined. Large, tender, very deep, milk-white grains. Pkt., 10c; 1 lb., 30c, postpaid.

LATE MAMMOTH SUGAR.-This is the latest and largest of all the Sugar Corns. The ears are immense, and of finer quality and flavor. Pkt., 10c; $1 \mathrm{lb} ., 30 \mathrm{c}$, postpaid.

\section{POP CORN}

QUEEN'S GOLDEN.-The largest Pop Corn. The talks grow 5 to 6 f'set high and bear two to three large eal's each. It is yellow, but pops perfectly white. Lb., 15c; 10 lbs., \$1.25, pastpair

WHITE RICE.-A very handsome and popular variety. Ears short, kernels long, point d, and resemble rice; color, whit?. Lb., 15c; 10 lbs., $\$ 1.25$, postpaid.

Write for Spscial Prices on Larger Quántities Than Listed.

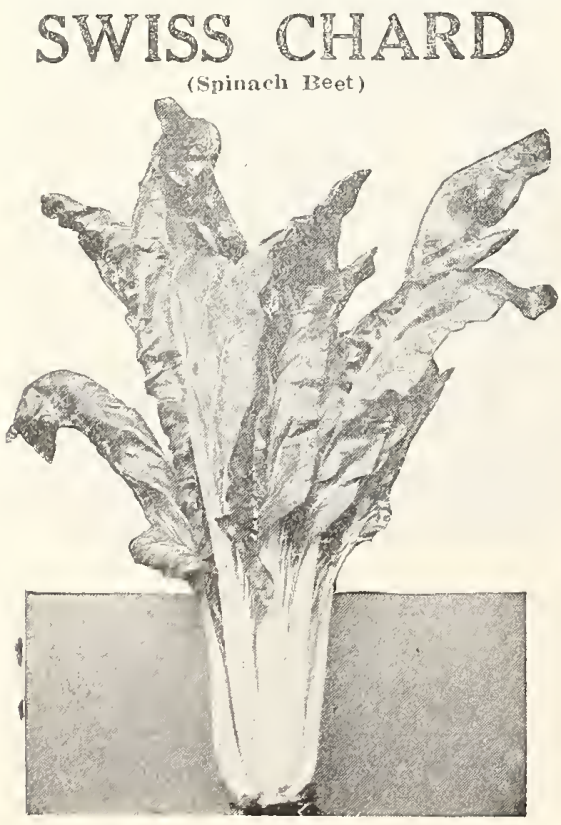

Culture,- Sow in well prepared soil between April 15 th and Iune 15th. One ounce will sow 50 feet of drill sow in drills 18 inches apart. cover 1 incl, No garden will be complete without Swis Chard, and the grower will be amply rewarded by giving it at least a small space.

Also called Sea Kale Beet. The middle of the leaf, or midrib, is cooked and served like asparagus. The other portions of the leaf may be used like spinach. This Beet does not make a large root, but is a delicious summer vegetable when cut young and used for "greens." There are several varieties of Swiss Chard. We recommend the Lucullus where the rib of the leaf is to be used. When wanted as a substitute for spinach, the Yellow cutting variety. We supply either sort at: Pkt., 10c; oz., 15c; 1/4 Ib., 35c; 1 lb., \$1.00, postpaid.

\section{ENDIVE}

Two ounces of seed to 100 yards of row; 3 pounds to the acre.

Culture.-Sow in the spring as soon as the earth is free from frost, and repeat to within 60 days of autumn frost. Drill in rows 2 feet and thin the plants to 8 inches apart. Tie up the loose leaves or cover with pots to blanch for salad. Valuable for salads and highly decorative as a garnish.

IMPROVED GREEN CURLED.-Finely fringed leaves of bright green color; tender and crisp when properly blanched. Pkt., 10c; oz., 15c; 1/4 lb., 35c; postpaid.

WHITE CURLED.-The thick center leaves are a pale yellow color, while the finely cut and curled outside leaves are pure white. Does not need blanching. Large size, and always tender and crisp. Pkt., 10c; oz., 15c; $1 / 4 \mathrm{Ib}$., $35 c$, postpaid.

\section{EGG PLANT}

Culture,-Thrives well in any good garden soil. Sow seed in not-bed or greenhouse in March or April, and when an inch high pot in 2 or 3 -inch pots or pot out in shallow boxes 4 inches apart each way Plant in open ground when danger of frost is past, in roms 2 feet apart each way. One ounce will yield 2,000 plants $1 / 4$ pound for an acre. To prevent blight and bugs, use Bordeaux mixture, with arsenate of lead, Paris green or Bug Deat

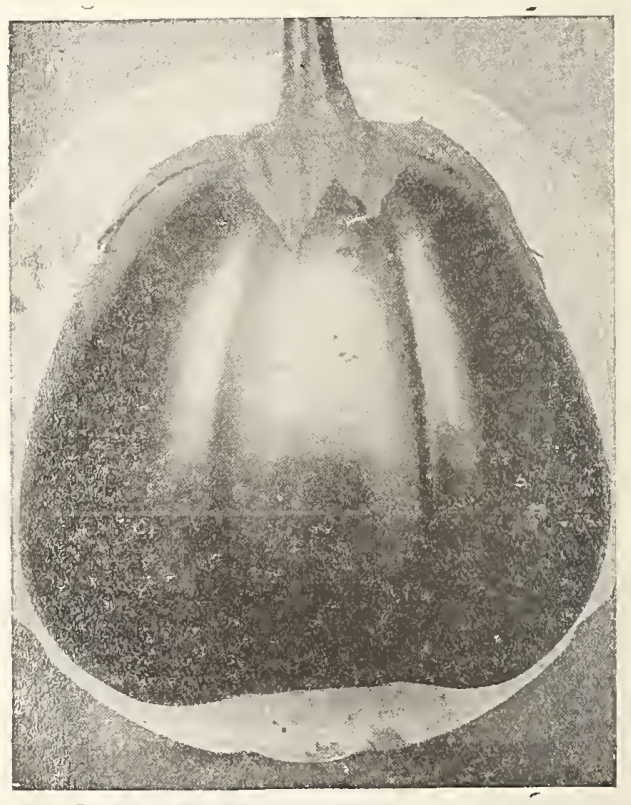

Now Vork Improved Purple.

NEW YOFK IMPROVED PURPLE.-One of the best and largest variaties in cultivation. Our strain of this variety is espacially fine. The plant is robust, low-growing, branching freely and bears long, oblong shaped fruits. We think this variety better than any other. Pkt., 10c; oz., $40 \mathrm{c} ; 1 / 4$ lb., $\$ 1.25$, postpaid.

BLACK BEAUTY.-Ten days or two weeks earlier than the precoling, with fruits just as large, uniform and rich, lustrous black color. Fruit develops very quickly and planters will be pleased with it. Pkt., 10c; oz., 40c; $1 / 4$ lb., $\$ 1.25$, postpaid. 


\section{GARLIC}

Used for llavorillg soups, sausages, etc. It is propagated by division of the roots into small parts. The bulbs are gathered in August in the same manner as onions. $1 / 2$ lb., 25c; 1 lb., 40c, postpaid.

\section{HERBS-Sweet, Medicinal and Pot}

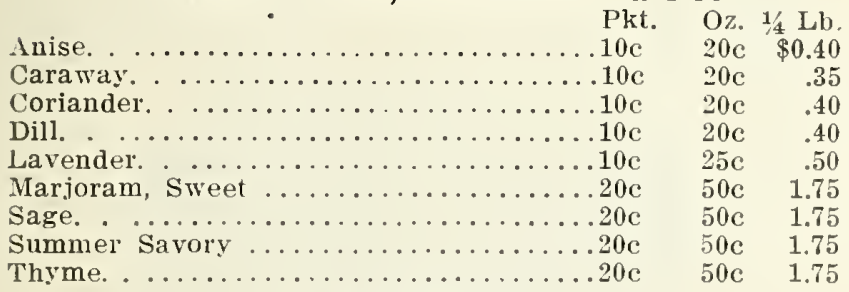

\section{LEEK}

Culture.-Similar to onions in flavor, but do not form a thick bulb. Sow as early as possible, 1/2 inch deep, when plants are large enough to handle transplant to rows 12 inches apart. setting plants 6 inches apart. Hill $u p$ as they grow to bicach stems or plant in trench like Celery and fill in as they grow. Seed may be sown in Septcmber and transplanted in spring. Ounce will sow 100 feet of drill.

LONDON FLAG.-Sow early in spring in drills, 1 inch deep and 1 foot apart. When 6 or 8 inches high, transplant in rows 12 inches apart and 5 inches between the plants as deep as possible that the neck may be blanched. An ounce will sow 150 feet drilled. Pkt., 10c; oz., 25c, postpaid.

\section{KALE OR BORECOLE}

Culture.-Used for greens in fall, winter and spring; sown broadcast or in drills is inches apart from early september to middle of October; can be sown in February and March, at which time Spring or Smooth Kale is best. This is also used in fall, as it makes rreens quicker than other varieties. should be protected with straw or coarse litter in winter so that plants can be cut through Winter varieties can be sown at rate of 3 to pounds to acre; Spring fiale can be sown broadcast at rate of 8 pounds per acre; 4 or 5 pounds in drills

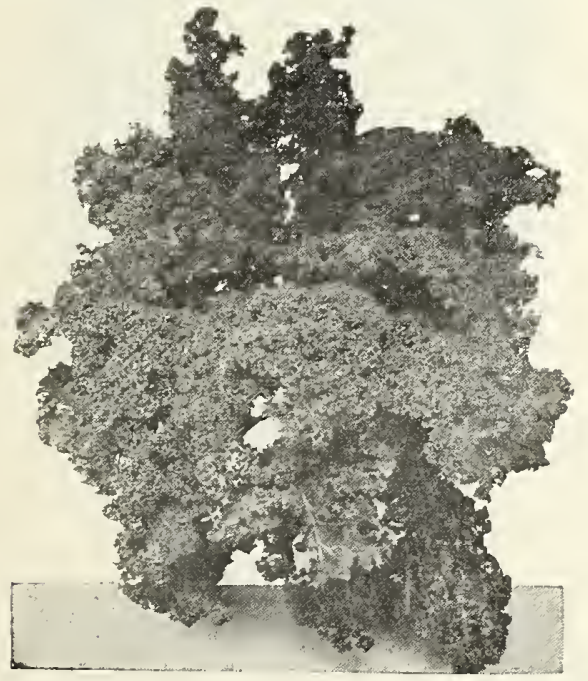

DWARF GREEN CURLED SCOTCH.-Grows about 12 inches high and spreads, under good cultivation, to 3 feet in diameter. Leaves bright green, beautifully curled, very tender. Allow to get a touch of frost before using. Pkt., 10c.; oz., 20c; 1/4 lb., 45c, potspaid.

\section{KOHLRABI}

EARLY WHITE VIENNA.-Extra fine for forcing. This variety is extremely early, with small tops. Bulbs are of medium size, light green or noarly white; best quality for table when 2 inches in diameter. Pkt. 10c; oz., 20c; $1 / 4$ lb., 50c; 1 lb., \$1.75, postpaid.
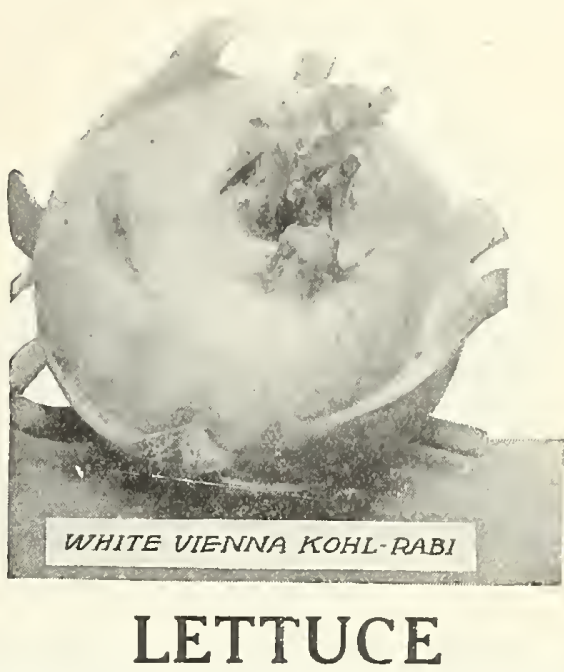

2 ounces of seed to 100 yards of row; 3 pounds to the acre. Forty to 50 days from seeding to maturity.

Cuiture.-For early outdoon culture, the seed may be planted in March or as carly as the ground can be worked. Sow in drills 14 inches apart, and thin the plants to 4 inches apart. For the heading varieties, where large heads are desired, plants should be thinned 8 to 10 inches to row. Lettuce sluould be grown very rapmanuring ant thorough preparation.

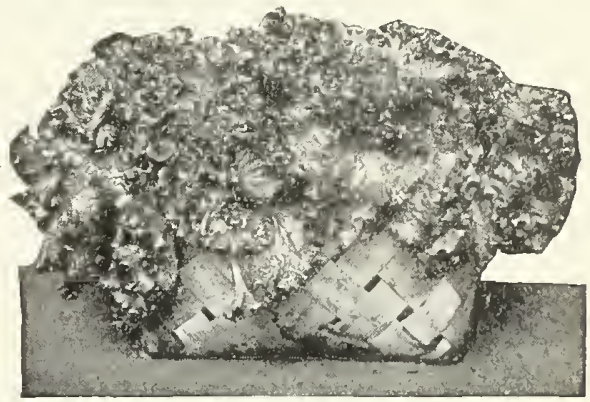

Grand Rapids.

OUR BIG BOSTON LETTUCE.-(40 days.) The king of main-crop head Lettuce. Blanches beautifully; crisp, tender and free from bitterness. It produces immense heads, solid as cabbage; often 15 and 16 inches across and weighing enormously. A very large, robust-growing variety, rooting deeply, resisting hot, dry weather; slow to run to seed, and a sure header under most trying conditions. Outer color is of distinct apple agreen. Been extensively grown by our customers in almost all sections of the country, from whom we receive most gratifying reports. Pkt., 10c; oz., 15c; 1/4 lb., 35c; 1 lb., \$1.00, postpaid.

PRIZE HEAD.-(3s days.) Very tender leaves of dark reddish brown color. variegated with dark green. Heads other brown-leaved variety. Pkt., 10c; oz., 15c; $1 / 4$ lb., $35 \mathrm{c} ; 1 \mathrm{lb} ., \$ 1.00$, postpaid.

DENVER MARKET.-(45 days.) Used eithel for fol'cing or open ground. An early variety, forming heads which are solid and of beautiful light green color, curled somewhat like Savoy Cabbage, and always crisp and tender. Pkt., 10c; oz., 15c; l/1 lb., 35c; 1 lb., $\$ 1.00$, postpaid.

IMPROVED HANSON.-(40 days.) Forms very large, firm heads, resembling Cabbage, which are deliciously sweet. crisp and tender; heads gleen outside and white inside. For outdoor culture unexcelled. It is one of the best heat-resisting sorts. Pkt., 10c; oz., 15c; 1/4 Ib., 35c; $1 \mathrm{lb} ., \$ 1.00$, postpaid.

MAMMOTH BLACK.SEEDED BUTTER.-A smoothleaved Lettuce, forming very large, compact, cabbage-like heads of thick, yellowish green leaves, the inner ones beautifully blanched, very crisp, tender and buttery. It is one of the most largely giown solts, suitable for the home garden as well as market. Pkt. 10c; oz., 15c;1/4 Ib., 35c; 1 ib., \$1.00, postpaid. 


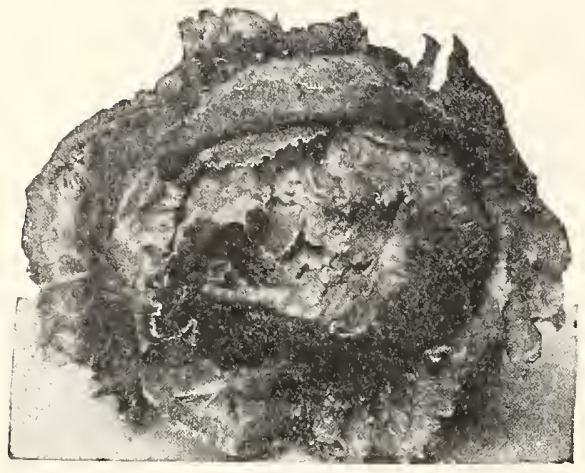

Big Boston

NEW YORK.- The large white heads resemble cabbage in their solidity, and frequently weigh two and three pounds each. The quality is superb, being crisp, rich and tender. It withstands the heat well, making a fine variety for all seasons. Pkt., 10c; oz., 30c; $1 / 4 \mathrm{lb} ., 90 \mathrm{c} ; 1 \mathrm{lb} ., \$ 3,00$, postpaid.

BLACK-SEEDED SIMPSON.-(40 days. $)$ An old standard, used largely for forcing and for early and late outdoor culture. Stands heat and drouth well. Leaves large, thin, and very tender, of a light green color, slightly curled. A fine sort for all seasons. Pkt., 10c; oz., 15c; 1/4 ib., 35c; 1 lb., $\$ 1.00$, postpaid.

EARLY CURLED SILESIA.-(38 days.) old farorite; dwarf, compact habit and quick growth, crisp golden leaves; finely curled edges. Pkt., 10c; oz., 15c; 1/4 lb., 35c; 1 Ib., $\$ 1.00$, postpaid.

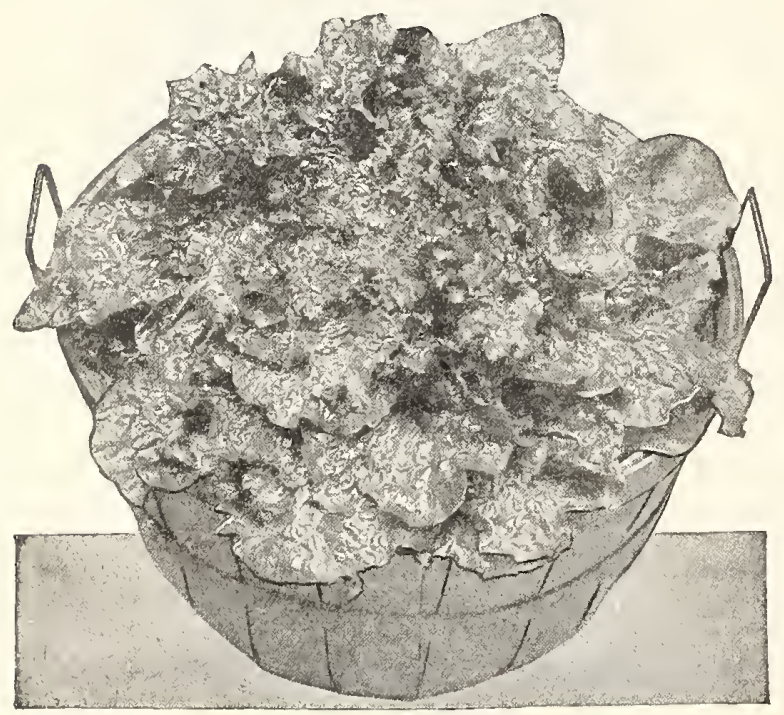

GRAND RAPIDS.-(40 days.) A forcing variety of superior quality and appearance, strong grower, free from rot, keeps crisp and tender without wilting when exposed for sale longer than any other forcing Lettuce. Also desirable for sowing in open ground. Pkt., 10c; oz., 15c; 1/4 Ib., 35c; i lb., \$1.00. postpaid,

EARLY CURLED SIMPSON.-(40 days.) A good forcing sort. White-seeded. Resembles the Black-Seeded Simpson Early. Pkt., 10c; oz., 15c; $1 / 4$ lb., 35c; 1 lb., \$1.00, postpaid.

PARIS WHITE COS-Grows to very large size. The inner leaves blanch readily and are of fine flavor. One of the most popular market sorts; also called White Paris Self-Folding Cos or Trianon Cos, Pkt., 10c; oz., 20c; 1/4 lb., $60 c$; 1b., \$2.00, postpaid.

\section{WATERMELON}

3 ounces of seed to 100 yards of row; 4 pounds to the acre.

Culture.-Watermelons do well upon sod ground or upon land prepared for their reception by plowing down a crop of winter wheat or winter rye, the sod or grain aerating or keeping loose the soll. When the apple is in bloom the seed is planted in hills 10 feet apart in each direction. Two large shovelfuls of well-rotted stable manure should be dug and trampled into each hill and covered with earth. The cultivator should be prepared with quite 4 pounds of seed to the acre, that he may have a reserve for replanting in case of destruction of his plants by insect depredations or beating rains. Only one vine to the hill should be allowed to attain perfection. With 450 hills to the acre, there should be 900 first class melons.

SWEET HEART.-( 80 days.) Early, large, oval, light green; splendid shipper. Pkt., 10c; oz., 15c; 1/4 lb., 30c; 1 Ib., 75c, postpaid.

GEORGIA RATTLESNAKE.-(90 days.) Melons are long in shape, of light green color, with dark stripes and grow of uniformly large size and symmetrical shape. In Georgia this variety is one of the most highly prized of all. The rind is remarkably thin, though it stands shipping well, and the flesh most tend $r$, sweet, and luscious, it being a rare thing to find a melon that is not of superior quality. Pkt., 10c; oz., 15c; 1/4 lb., 30c; 1 lb., 75c, postpaid.

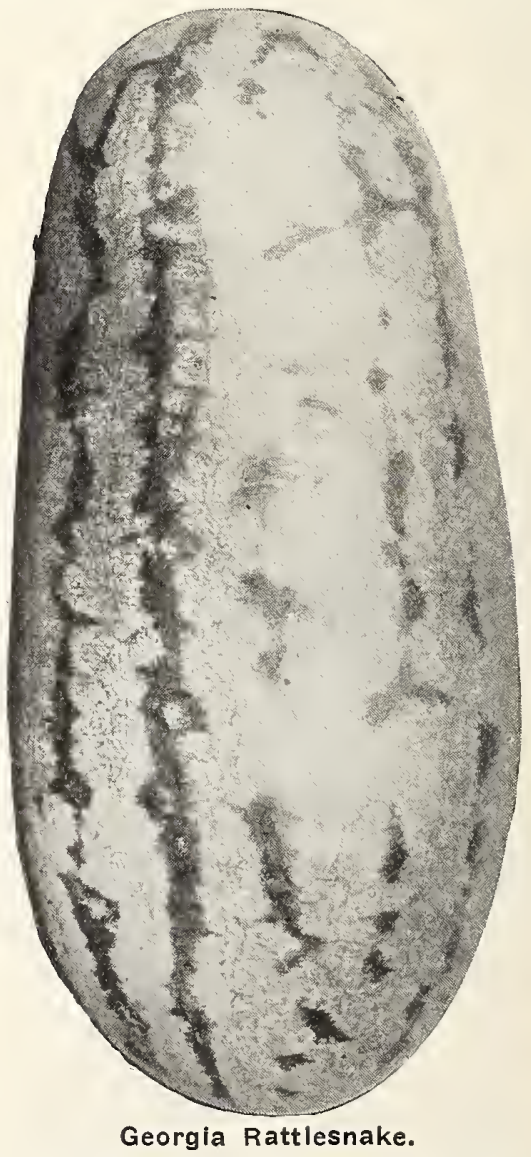

TOM WATSON.--(85 days.) A new variety, destined to becume a leader among Melons because of quality and shipping excellence. There is no variety, to our knowledge, that combines both essentials as does this Melon. Most sorts of extra quality are not tough enough to ship, and most shipping Melons are too tough to excel in quality. The Tom Watson is a large, oblong Melon, the skin of which is dark green, with thick netting on the entire surface, guite distinct from other varieties. It averages 18 to 24 inches long and 10 to 12 inches in diameter, and weighs 50 to 60 pounds. The rind is thin. but tough. and flesh a bright, attractive red color, crisp, sweet and dolicious. The heart is large, with no core. Seeds brown, tipped white. Pkt., 10c; oz., 15c; 1/4 lb., 30c; 1 lb., 75c, postpaid. 


\section{WATERMELON-Cont.}

HALBERT HONEY.-( 85 days.) Too much cannot be said of the merits of this grand new sort for market or home purposes. Its vine is of strong, vigorous growth, and sets fruit freely. Seed white. Flesh is bright red, exceedingly sweet and tənder; absolutely stringless. Good keeper. In size it is large to mammoth, and presents a fine appearance on the market, as well as the dining table. Seed direct from the originator. Pkt., 10c; oz., 15c; 1/4 Ib., 30c; 1 lb., 75c, postpaid.

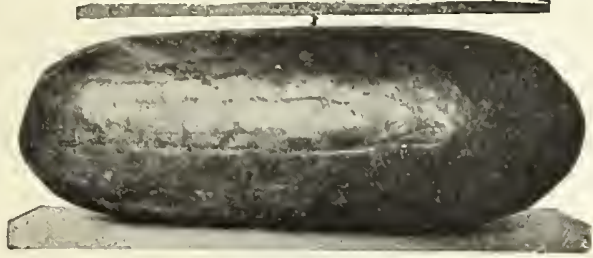

Tom Watson.

KLECKLEY SWEET.- $(85$ days.) This is one of the best flavored Melons in cultivation and of a shape and color that is extremely desirable. The rind is very dark green. very thin, flesh deep scarlet. fine, and of delicious quality. For the home market and family garden it is decidedly the best. Pkt., 10c; oz., 15c; 1/4 lb., 30c; $1 \mathrm{lb} ., 75 \mathrm{c}$, postpaid.

ALABAMA SWEET.-(95 days.) A very large, long Melon of fille quality, very popular in the South, where it is grown extensively for shipping. Rind firm, rather dark green, sligbtly striped: flesh bright red, seed white. Pkt., 10c; oz., 15c: $1 / 4$ lb., 30c: 1 lb., $75 c$, post paid.

ROUND LIGHT ICING.-Fruits are small-medium nearly round; greenish white. slightly veined or dotted with light green. Flesh is bright, light red, sweet and tender: seed white. Pkt., 10c; oz., 15c; 1/4 lb., 30c; 1 lb., $75 \mathrm{c}$, postpaid.

COLE'S EARLY.-(78 days.) A hardy, sure cropper; nearly round; flesh dark red; rind thin and extremely brittle; medium size; green striped with lighter shades. Pkt., 10c: oz., 15c: 1/4 Ib., 30c: 1 lb., 75c, postpaid.

PHINNEY'S EARLY.-(80 days.) Medium size: flesh a deep red: rind thin. Pkt., 10c; oz., 15c; 1/4 lb., 30c; $1 \mathrm{lb}$. , $75 c$, postpaid.

FLORIDA FAVORITE.-(90 days.) Large, oblong; rind dark green. with stripes of lighter green. A popular variety in the South. Pkt., 10c; oz., 15c; 1/4 Ib., 30c; $1 \mathrm{lb}$, $75 \mathrm{c}$, prstpaid.

CITRON, RED-SEEDED.-For pickles and preserves only. Unpalatable in raw state. Pkt., 10c; oz., 20c; $1 / 4 \mathrm{lb}$., $50 \mathrm{c} ; .1 \mathrm{lb}$. $\$ 1.50$, postpaid.

KOLB'S GEM.-(95 days.) Has no superior for shipping purpoess. Fruit large. oval-shaped. marked with mottled: brittle; medium size: green striped with lighter shades. Pkt., 10c; oz., 15c; 1/4 lb., 30c: 1 lb., 75c. postpaid.

ICE CREAM, OR PEERLESS.-(90 days.) Popular for home market. Medium size. almost round; skin pale green, slightly mottled; flesh bright scarlet, fine-grained. None better. Pkt., 10c: oz., 15c: 1/4 lb., 30c; 1 lb., 75c, postpaid.

HARRIS'S EARLIEST.-An extra early Melon of excellent quality. Fruits are exceptionally large for so early a variety. slightly oval with irregularly mottled broad stripes of light and dark green. Flesh is bright red, sweet and tender. Seed black. Vines are vigorous and productive. One of the best varieties for Northern latitudes. We have carefully observed this variety in our trials for several seasons and are convinced that it is the best first early melon for the home garden. Pkt., 10c; oz., 15c; $1 / 4$ Ib., 30c; 1 lb., 75c, postpaid.

\section{CANTALOUPE OR MUSKMELON}

Two ounces of seed to 100 yards of row; 4 pounds to the acre.

Culture-Melons do best in sandy soil or sod land and the soil shouldure.- with 10 to 12 seeds in each hill. Plant the seeds an inch deen whon danger of frost la over, thinning to 4 good plants to a hill. Culti vation should be kept up as long as possihle. One ounce of seed is suffiolent for 50 hills; 2 pounds per acre. Plant in May or June.

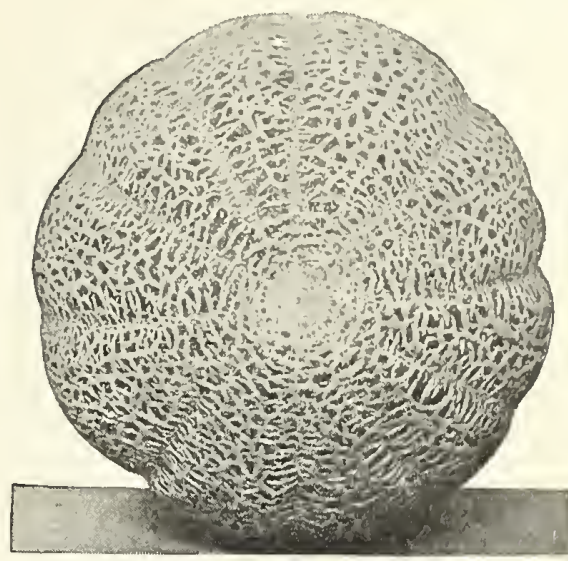

Rocky Ford.

\section{GREEN-FLESHED VARIETIES}

ROCKY FORD.-(70 days.) This has become one of the most popular of small or crate Melons, and is shipped in large quantities from Colorado and Arizona. The vines are vigorous and productive. The fruits are oval, slightly ribbed. densely covered with fine netting. Flesh green, very sweet and highly flavored. We offer an exceptionally fine stock of this early sort, the fruit being very uniform in shape and quality and of the even size that is so desirable in a shipping Melon. Pkt., 10c; oz., 15c; 1/4 Ib., 40c; 1 Ib., \$1.35, postpaid.

NETTED GEM.-(70 days.) In many sections considered an improvement on the Rocky Ford because of its more perfect netting, safeguarding it against abrasion or ribs. Pkt., 10c; oz., 15c; $1 / 4$ lb., 40c; 1 lb., $\$ 1.35$, postpaid.

EXTRA EARLY HACKENSACK.-(70 days.) We offer distinct stock, very different from and much superior to that often sold as Extra Early Hackensack. The fruit : are nearly two weeks earlier than Hackensack, medium to large sized, nearly round or somewhat flattened evenly and deeply ribbed, and with very coarse neting. The skin is green. slightly tinged with yellow as the fruit matures; the flesh is green, a little coarse, but juicy and sweet. Pkt., 10c; oz., 15s; 1/4 Ib., 40c; 1 lb., \$1.35, postpaid.

HONEY DEW.-The Melon with an appropriate name. A new member of the Melon family, propagated after seven years of experimenting. The new fruit, which is called the Honey Dew Melon, is a cross between the Rocky Ford Cantaloupe and a South Sea Island fruit, Pkt., 10c; oz., 15c; $1 / 4$ Ib., 40c; 1 lb., \$1.35, postpaid.

HACKENSACK.-A large, deeply netted Melon, flattened at the ends, of most delicate flavor and very productive. Pkt., 10c; oz., 15c; 1/4 lb., 40c; 1 lb., $\$ 1.35$, postpaid.

\section{ORANGE-FLESHED VARIETIES}

BURRELL'S GEM.-(80 days.) A truly dəlicious Melon for home use, or if you desire a fancy price on the market we recommend the Burrell Gem. About same size and shape as Rocky Ford. Has rich golden yellow flesh of

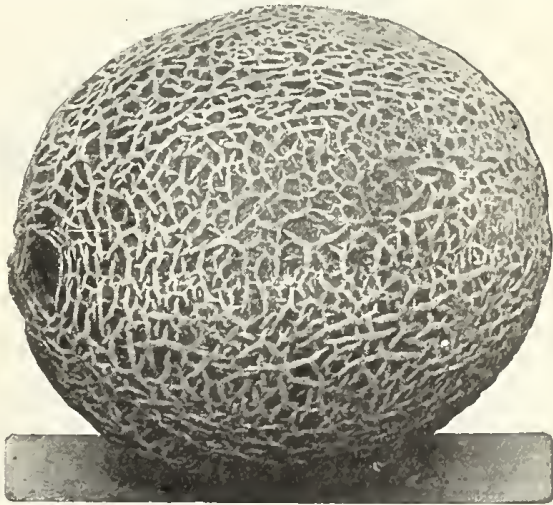

Burrell's Gem. 


\section{CANTALOUP OR MUSK- MELON-Cont.}

nost delicious flavor, solid, and a most desirable shipping sort. Seed cavity very small. Melons average about 6 inches long, $4 \frac{1}{2}$ inches in diameter, and weigh $2 \frac{1}{4}$ pounds. Shipments to Chicago, St. Louis, New York and elsewhere brought 50 per cent more than best Rocky Fords. Pkt., $10 \mathrm{c}$; oz., I5c; 1/4 Ib., 40c: 1 Ib., \$1.35, postpaid.

EXTRA EARLY OSAGE.-(75 days.) Fully a week earlier than the Osage, fruits a little smaller, more nearly round, and the netting extends over more of the surface. These very desirable features, combined with the thick, deep salmon-colored flesh and small seed cavity charactelistic of the Osage, make this Melon deserving of a place in every home and market garden. Pkt., 10c; oz., 15c; 1/4 Ib., 40c; 1 Ib., \$1.35, postpaid.

BANANA.-Externally it is of a creamy white or delicate straw color. The flesh (the Melon being nearly solid) is of a rich salmion. The quality is first rate when the melons are thorouglily ripe. It grows from 18 inches to 2 feet in length, and is very prolific. When ripe, it smells like a banana. Pkt., 10c; oz., 15c; I/A lb., 40c; 1 lb., \$1.35, postpaid.

CASABA MUSK MELON.-(140 days.) A class of late maturing Melons which do not ripen on vines in the North, but are gathered betore freezing weather and stored in a cool place and brought to a warm room for ripening; can be eaten any time to Christmas, as they keep very long. Pkt., 10c; oz., 15c; 1/4 lb., 40c; 1 lb., \$i.35, postpaid.

EMERALD GEM.-A variety of excellent quality. It is of medium si\%e. Skin is perfectly smooth and a deep emerald green color. Flesh is thick and of a suffuse salmon color", and ripens to the green rind. Peculiarly crystalline in appearance and so very juicy that it almost drops to pieces when dipped out with a spoon. Flavor is very sweet and luscious. The vines are hardy and very prolific, and the Melons mature extremaly early. Pkt., 10c; oz., 15c; l/4 Ib., 40c; 1 lb., $\$ 1.35$, postpaid.

TIP-TOP MELON.-This Muskmelon should be planted by every gardener. Always pleases. The testimony of all is that every Melon, whether large or small, early or late, is a good one; sweet, juicy, f'inest flavor, firm, but not hard flesher, and edible to the outside coating. Its appearance on the market is very attractive. Gardeners tell us that their customers soon learn to pick them out and will have no other kind. Fruit is large size, nearly round, evenly ribbed, and moderately netted. Perhaps the most productive Melon known. Pkt., 10c; oz., 15c; 1/4 Ib., 50c; 1 lb., \$1.85, postpaid.

\section{MUSTARD}

One ounce will sow 50 feet of row.

Culture.-The leaves of these varieties of Mustard, as here isted, make excellent greens, of sharp pungent flavor, and are cooked the same as spinach or beet leaves. Sow the seed In drills early in the spring and at frequent intervals throughout the sum. mer to secure a constant supply of fresl greens. Mustard is liardy and easily grown.

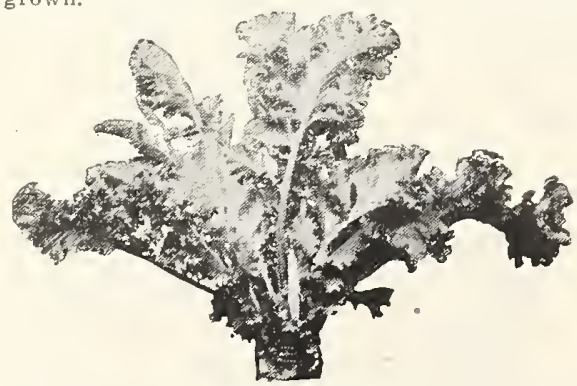

Ostrich Plume.

OSTRICH PLUME.-Most beautiful variety, of very superior flavor. These leaves are beautifully ruffled and curled and curve outward, like graceful ostrich plumes. 'They are excellently adapted for garnisling. It originated in the South, and stands hot weather exceedingly well. Sow in February, March or Aril, or during September and October. Pkt., 10c; oz., 15c; 1/4 Ib., 25c; 1 lb., 75c, postpaid.
SOUTHERN GIANT CURLED.-Highly esteemed in the South, where seed is sown in fall and plants used early in spring as salad. Seeds brown. Plants 2 feet high; enormous bunches. Pkt., 10c; oz., 15c; $1 / 4 \mathrm{lb} ., 25 \mathrm{c} ; 1 \mathrm{lb}$., $75 \mathrm{c}$, postpaid.

CHINESE.-A giant curled variety, with leaves double size ordinary. Pkt., 10c; oz., 15c; 1/4 Ib., 25c; 1 lb., $75 \mathrm{c}$, postpaid.

WHITE.--Leaves are light green, mild, and tender when young; seed light yellow in color. Pkt., 10c; oz., 15c; 1/4 lb., 25c; 1 lb., 75c, postpaid.

BROWN OR BLACK MUSTARD.-More pungent in Ilavor than the white. Seed black. Pkt., 10c; oz., 15c; 1/4 Ib., 25c; 1 lb., 75 c, postpaid.

\section{MUSHROOM SPAWN}

AMERICAN PURE MUSHROOM SPAWN.-Write for prices.

\section{NASTURTIUM}

Culture.--Nasturtiums ale useful for furnishing tender seed-pod which makes delicious pickles. Seeds fol pickling should be gathered while green and with portion of stem attached. Pick them over and place in a jar until filled; cover them with cider vinegar brought to the boil and is still warm, to keep for winter use.

TALL OR DWARF MIXED.--Pkt., 10c; oz., 15c; 1/4 Ib., 30 c; 1 Ib., $\$ 1.00$

\section{OKRA OR GUMBO}

Culture.-Okra is a highly esteemed vegetable throughout the entire country and the demand is getting bigger and bigger all the ime. The young, tender pods are used mainly in soups and stews, although they are excellent when boiled and served hot or cold a salad. Some persons may not enjoy the flavor of Okra at flrst, but after eating it a few times a taste for it is naturally acquired. Plant 1 ounce of seed to 50 feet of row; about 8 pounds to the acre. Three-foot rows are good, planting the seed 3 to 4 inches apart to allow space for the development of the stem.

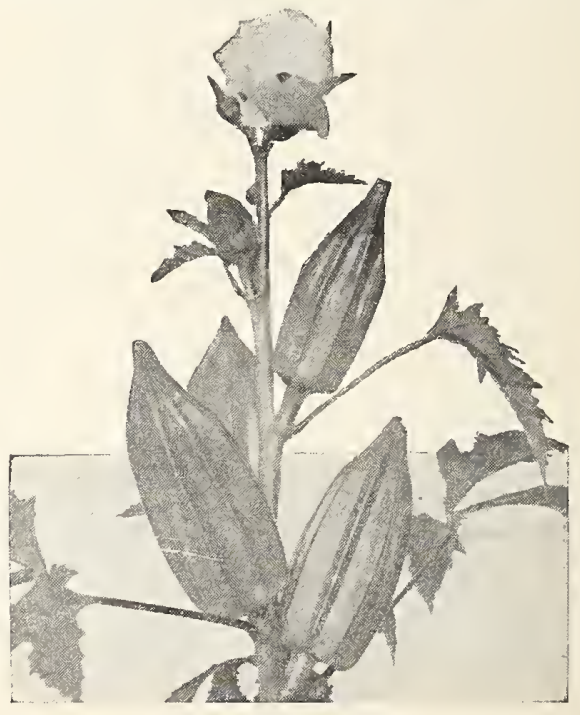

Improved Dwarf.

MAMMOTH LONG.PODDED OKRA.-This is a distinct variety and is largely cultivated for shipping purposes. Very productive, pods starting to shoot out within three or four inches from bottom of stalk, and the whole plant is covered with them to the height of 5 to 6 feet. Pods are of an intensely dark green color of unusual length, frequently 9 to 10 inches long. Are slim and do not harden as is usually the case with other slender sorts. Pkt., 10c; oz., $15 \mathrm{c} ; \mathrm{l} / 4 \mathrm{lb} ., 25 \mathrm{c} ; 1 \mathrm{lb} ., 65 \mathrm{c}$, postpaid.

IMPROVED DWARF.-An early variety; pods short, but very numerous. Pkt., 10c; oz., 15c; $1 / 4$ lb., 25c; 1 lb., $65 \mathrm{c}$, postpaid.

WHITE VELVET.-Pods large, white, smooth, superior quality, an excellent bearer. Pkt., 10c; oz., $15 \mathrm{c} ; 1 / 4 \mathrm{lb}$., 25c; 1 lb., 65c, postpaid. 


\section{ONION}

Onion growers who use large quantities of seed should write for special prices.

Culture.-One ounce will sow 100 feet of drill. To grow large onions from seed, sow 5 pounds to the acle; to grow small sets, 60 to 70 pounds to the acre will be requiled.

Raising a crop of onions requires too much labor and expenso to run the risk of planting anything but reliable seed. There is no other vegetable in which the quality of the seed exerts so great an influence. Fully realizing the importance of good seed, we havo made ouality our first consideration in the srowing and marketing of onion seed. Our stock is all home-grown from choice solected bulbs and is the best liat cal bo produced. We ouaranteelected bulbs, and is the best hat ean lic prodiced. We guarantee every pound of onion seed to be new secd or high germination. Our seed is all tested, and we know it will grow and give satisiaction. 1 chances on cheap, poor seed. Buy our seed and get the best.

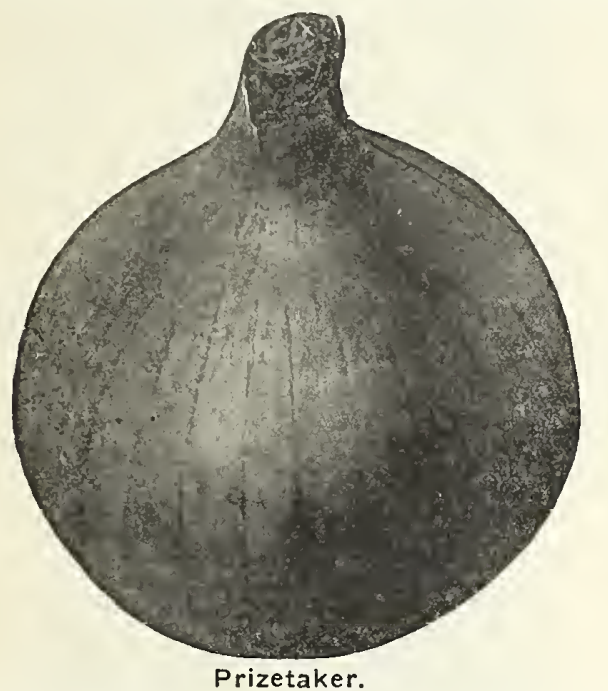

PRIZETAKER.-(90 days.) This is beyond question the handsomest Onion grown. Yellow or straw color, flesh white, of enormous size, in many cases weighing f'rom 3 to $31 / 2$ ounds. Very hardy and a good keeper. Flavor sweet, very mild and tender. Pkt., 10c; oz., 20c; 1/4 Ib., 50c; $1 \mathrm{lb}$. , $\$ 1.75$, postpaid.

YELLOW GLOBE DANVERS.-(100 days.) A very handsome, round American variety of large size; very fine and mild; an excellent keeper. Pkt., 10c; oz., 20c; $1 / 4$ lb., $60 \mathrm{c} ; 1 \mathrm{lb} ., \$ 2.00$, postpaid.

SOUTHPORT WHITE GLOBE.--(100 days.) One of the most beautiful Onions grown, being symmetrical globe shape, with a smooth satin-white skin, forming a perfect silver ball. It grows to a large size, averaging $71 / 2$ to 9 inches in circumference, and is solid and heavy. The flesh is purest white, close and fine-grained, mild and of moderate flavor. It is a heavy cropper, yielding under good culture up to 900 bushels per acre. Our strain of this seed is grown from picked thin-necked bulbs, which ripen so uniformly and so thoroughly that the Onions keep nearly as well as the Red and Yellow varieties. Pkt., 10c; oz., 20c; $1 / 4$ lb., 60c; 1 lb., $\$ 2.00$, postpaid.

LARGE RED WETHERSFIELD.-The standard variety throughout the West, as they are the most hardy, and an immense crop can be raised when more tender varieties are not profitable. One of the best winter keepers. It is not an early ripening sort, but continues to grow throughout the season, consequently making very large Onions. The outer skin is a deep rich purplish red, flesh white, lightly tinged with pinkish rose. Our seed of this variety is extra select and cannot be excelled. Pkt., 10c; oz., 20c; $1 / 4$ lb., 50c; 1 lb., $\$ 1.75$, postpaid.

SOUTHPORT YELLOW GLOBE.-(110 days.) The true Southport Onions are very handsome globes of superior quality. They are excellent keepers, uniform in size and form, and command higher market prices than any other kind. We highly recommend the Yellow Globe. It ripens a little earlier than the Red, grows to an average size of 2 to 3 inches in diameter, and has all the good qualities mentioned above. Pkt., 10c; oz., 20c; 1/4 lb., 50c; $1 \mathrm{lb} ., \$ 1.75$, postpaid.
SOUTHPORT FED GLOBE.-(100 days.) The handsomest of all the Red Onions; large, solid and of perfect shape. Red Globe is the latest of the Southport Onions, ripening from a week to ten days after the Yellows. The bulbs are uniform, of a rich, red color, ripen evenly, and yield the largest percentage of marketable Onions. They ripen down hard and solid, keep well, and their beautiful appearance insures a ready market. Southport Red Globe will yield a heavier crop than ejther the Yellow or White Globe. Pkt., 10c; oz., 20c; 1/4 Ib., 50c; 1 lb., \$1.75, postpaid.

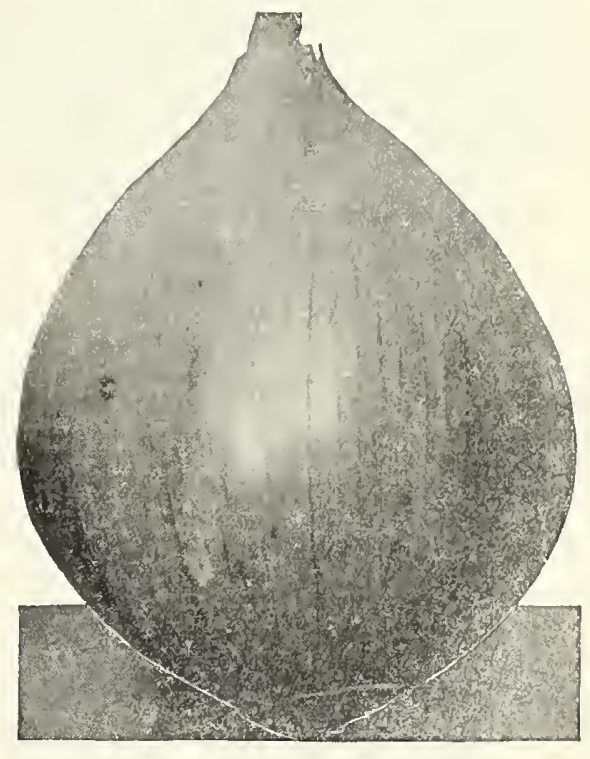

Yellow Globe.

WHITE PORTUGAL, OR SILVERSKIN.-A large flat White Onion of mild and pleasant flavor, hard and finegrained and a good keeper. Extensively sown for sets, and is also largely grown for pickling. Pkt., 10c; oz., 20c; $1 / 4$ lb., 60c; 1 lb., $\$ 2.00$, postpaid.

AUSTRALIAN BROWN.-A long keeper; early, a fine cropper. Pkt., 10c; oz., 20c; $1 / 4$ lb., 60c; $1 \mathrm{lb}$., $\$ 2.00$, postpaid.

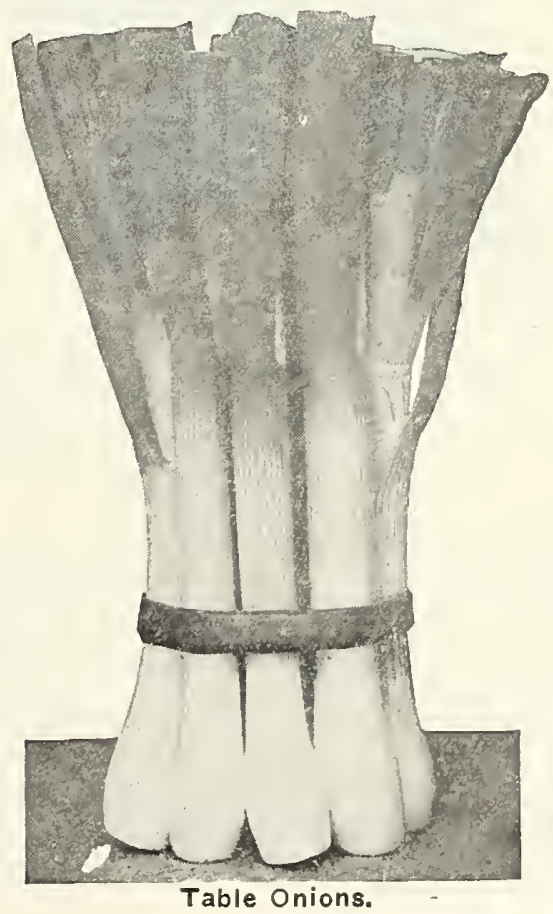




\section{ONION-Cont. ONION SETS}

Culture.-To raise Onion sets from seed, use good ground prepared as for large onions and sow the seed very thick In broad drlls using 40 to 60 pounds per acre. If the seed is sown thin, the bulbs will not only be too large for sets, but will not be of the rlght shape, and if sown thick on poor land they will be necky or bottleshaped. Onion seed sown for sets may be planted somewhat later than if a crop of large bulbs is desired.

RED AND YELLOW BOTTOM SETS.-Treated precisely as top Onions are, setting them out in the spring instead of sowing seed. Lb., 15c, postpaid; 20 lbs., \$2.50, postpaid.

WHITE SILVERSKIN. - Produce beautiful White Onions early in the season. Lb., 20c; postpaid; 20 lbs., $\$ 3.50$, postpaid.

\section{GARDEN PEAS}

Culture. - Sow as early as possible a few of some of the early varietles in warm sandy soil The seed can be sown in rows in a very satisfactory way. It is best to sow in an open way with a hoe, the full width of it, and broarleast the seed thinly in the bottom. Later plantings should be of the wrinkled varieties; they are better yielders, sweeter, and very higlily flavored. A pint will sow a row of 50 feet. Use from $1 \frac{1 / 2}{2}$ to $1 \frac{3 / 4}{4}$ bushels to the acre, making rows from $2 \frac{1 / 2}{2}$ to 3 feet apalt Ground should be cultivated about every two weeks, heeping weeds and grass free from same. Early varleales will mature in about 50 or 60 days, later varieties in about 70 to 85 days.

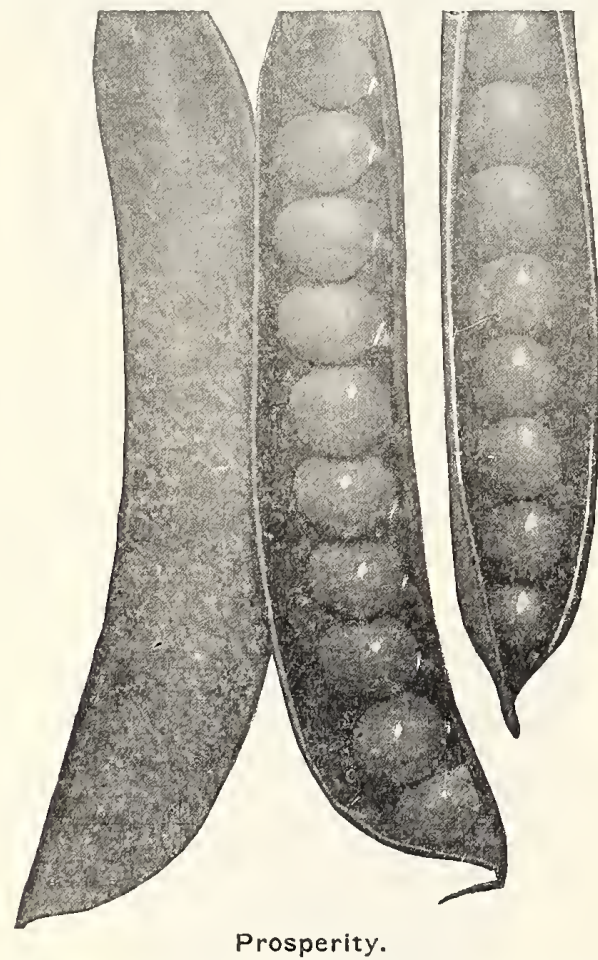

ALASKA.-( 45 days.) Witlout doubt the earliest and best smooth Blue Pea, ranking with the First-and-Best as to evenness, uniformity in ripening and earliness. Ripens all the crop at once; an invaluable variety for market gardeners and canmers. Vines 2 to $21 / 2$ feet high. Pkt., 10c; 1 lb., 35c; 10 lbs., \$2.50, postpairl

NOTT'S EXCELSIOR.-(53 days.) Fifteen inches. Dwarf Wrinkled Pea. The pods average fully one-third larger than the American Wonder, and it is all ready for picking at one time. Each pod contains six to eight large peas, which are unusually sweet. Pkt., 10c; 1 lb., 35c; 10 Ibs., \$2.75, postpaid.

FIRST-AND-BEST.-(47 days.) A round-seeded Pea that can be sown when frost is barely out of ground, before it is safe to sow wrinkled-seeded sorts. This, with its quick growth and maturity, renders it the earliest Pea on record. Unequaled for general excellence. yield, size of pod and regularity. It is $2 \frac{1}{2}$ feet high. Pkt., 10c; $1 \mathrm{lb} ., 35 \mathrm{c}$; 10 Ibs., \$2.50, postpaid.
GRADUS, OR PROSPERITY.-(58 days.) This Pea is not only large and of best quality, but nearly as early as the small, round, extra early sorts. It is hardy and may be planted as soon as ground is fit to work in the spring, along with smootl Peas. Vine grows about 30 inches. Pods are a light green color and measure 4 inches or more in length, being as large as Telephone and as well filled; 8 to 10 in a pod. The Peas are fine table quality, and retain their color and attractive appearance after cooking. It is a grand Pea. Pkt., 10c; 1 lb., 35c; $10 \mathrm{lbs} ., \$ 2.75$, postpaid.

\section{MAIN-CROP VARIETIES}

THOMAS LAXTON.--An early variety of large-podded Pea, which is very hardy and a strong grower, producing pods in abundance. The habit and growth of vine resembles Gradus, although the color is darker and pods more blunt in shape. The nods are well filled with large peas; height, 3 feet. By express or freight, at purchaser's expense. Pkt., 10c; Ib., 35c; 10 ibs., $\$ 3.00$.

BLISS EVERBEARING.-(60 days.) A green-seeded, wrinkled, slightly flattened variety. Height, about 2 feet. Very hardy, a vigorous grower and an enormous cropper. Pods and peas of large size and superior quality. Pkt., 10c; 1 lb., 35c; 10 lbs., $\$ 2.75$.

AMERICAN WONDER.-(55 days.) The earliest of the wrinkled Peas and best for family use. Very dwarf, 9 inches high, and remarkabły productive; well-filled pods; flavor unsurpassed. Pkt., 10c; $1 \mathrm{lb} ., 35 \mathrm{c} ; 10 \mathrm{lbs} ., \$ 2.75$, postpaid.

MCLEAN'S LITTLE GEM.-(58 days.) Eighteen inches. A few days later than First-and-Best. Matures in eight weeks. When in a green state the Peas are sweet and delicious. Pkt.. 10c: $1 \mathrm{lb} ., 35 \mathrm{c} ; 10 \mathrm{lbs} ., \$ 2.75$, postpaid.

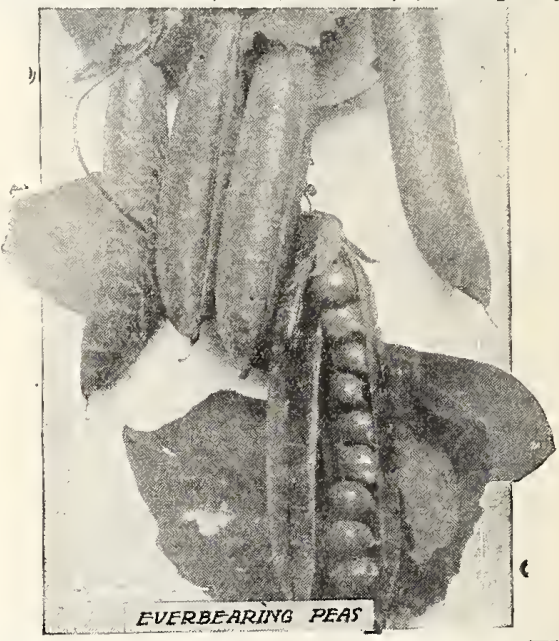

CHAMPIUN UF ENGLAND.- $(62$ days.) We offer a select strain of this grand old favorite, too well known to require extended description. It is a main crop and late variety of vigorous growth, about 5 feet high. Pkt., 10c; 1 lb., 35c; 10 lbs.. $\$ 2.75$, postpaid.

TELEPHONE.-Large-podded variety of Pea for general crop. Vines are very strong in growth and average 18 to 20 pods per stalk. The pods are of large size, containing 6 to 7 peas each, which are a pale green color and of delicious flavor. Height, $31 / 2$ feet. Pkt., 10c; 1 lb., 35c; 10 lbs., \$2.75, postpaid.

STRATAGEM.-Vines strong, vigorous and covered with immense pods, many measure 5 inches in length and contain 10 fine large, richly flavored, uniform wrinkled peas. Peas are dark greenish color, and are tender and sweet. Pkt., 10c; 1 lb., 35c; 10 lbs., \$2.75, postpaid.

WHITE MARROWFAT.-(65 days.) A favorite sort. Five feet. Pkt., 10c; $1 \mathrm{lb} ., 30 \mathrm{c} ; 10 \mathrm{lbs} ., \$ 2.25$, postpaid.

CANADA FIELD PEAS.-For dairy cows and hogs they are equal to corn and six weeks earlier. Should be sown early in April with Oats, using 2 bushels of Oats and 2 bushels of Peas per acre. Peas should be sown first and plowed under to a depth of about 4 inches, then sow and harrow in the Oats. Ready to cut in July. As fertilizer, they come next to Clover and will grow on land that will not produce Clover. Lb., 15c; 10 lbs., \$1.25. 


\section{PARSNIP}

One ounce will sow 200 feet of drill; 5 pounds will sow an acre in drills.

Culture.-Parsnips are uusally grown on deep, rlch, sandy soll, but will make good roots on any soll which is deep, meliow and moderately rich. Fresh manure ls apt to make roots coarse and III-shaped. As seed is sometimes slow and uneven in growth, It should be sown as eariy as possibie, in drilis $2 \frac{1 / 2}{2}$ feet apart; cover 1. inch deep and press the soil firmiy over the seed. Give frequent cuitivation, thin the piants to 6 inches apart in row.

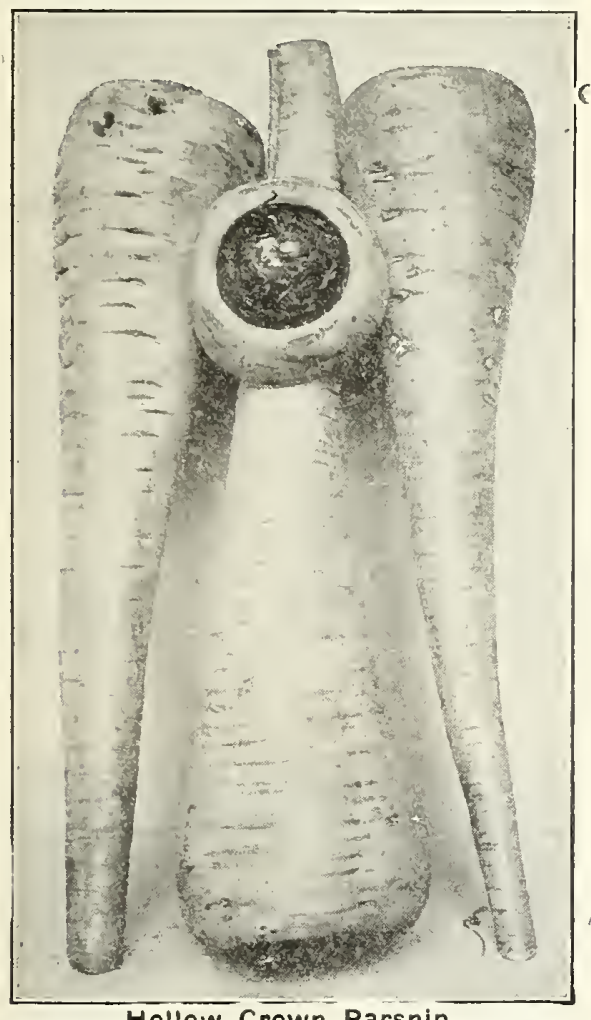

Hollow Crown Parsnip.

IMPROVED TABLE GUERNSEY.-A greatly improved and wonderfully fine strain of the Guernsey Hollow Crown Parsnip. The roots do not grow as long as the Hollow Crown, but are of greater diameter and more easily gathered. A very heavy cropper. Roots are smooth, with a deep hollow crown and a small top. Flesh fine-grained, sweet, and of excellent quality; cooks evenly, center being as fine, soft, even quality as outside portion. Pkt., 10c; oz., $20 \mathrm{c} ; \mathrm{l} / 4 \mathrm{lb} ., 60 \mathrm{c} ; 1 \mathrm{lb} ., \$ 2.00$, postpaid.

IMPROVED HOLLOW CROWN.-This greatly Im. proved strain is about the same shape as the old sort, but smoother and of more even quality; fine grained and excellent. Pkt., 10c; oz., 20c; 1/4 lb., 60c; 1 lb., \$2.00, postpaid.

\section{PEPPER}

Culture.-Sow the seed $1 / 2$ inch deep in hot-bed, greenhouse or warm window in March or April. After all danger of Prost, set out in open ground. A warm. moist soil is best, with plenty of rotted manure plowed under Set in rows 2 to 3 feet apart and 18 Inches apart in the rows. Cuitivate frequently throughout the season to keep the soil mellow and free from weeds. One ounce will produce about 1.500 plants; $1 / 4$ pound to transplant for an acre.

LARGE BELL, OR BULL NOSE.-Early and mild; a favorite for pickling; very prolific. Pkt., 10c; oz., 50c; $1 / 4$ Ib., $\$ 1.50$, postpaid.

CHINESE GIANT.-The largest red variety, Early in ripening and immensely productive for so large a Pepper. Its enormous size will cause it to sell most rapidly. Monstrous fruits are of thick, blocky form, and of brilliant, glossy scarlet. Grow 4 to 5 inches broad at top and are of equal length. Flesh is extremely mild and unusually thick; makes an excellent salad sliced and served like tomatoes. Pkt., 10c; oz., 65c; 1/4 Ib., \$1.75, postpaid.

LONG RED CAYENNE.-Cone-shaped red pods. Used for sauce and pickles. Pkt., $10 \mathrm{c} ;$ oz., $40 \mathrm{c} ; \mathrm{I} / \mathrm{a} \mathrm{lb} ., \$ 1.50$, postpaid.

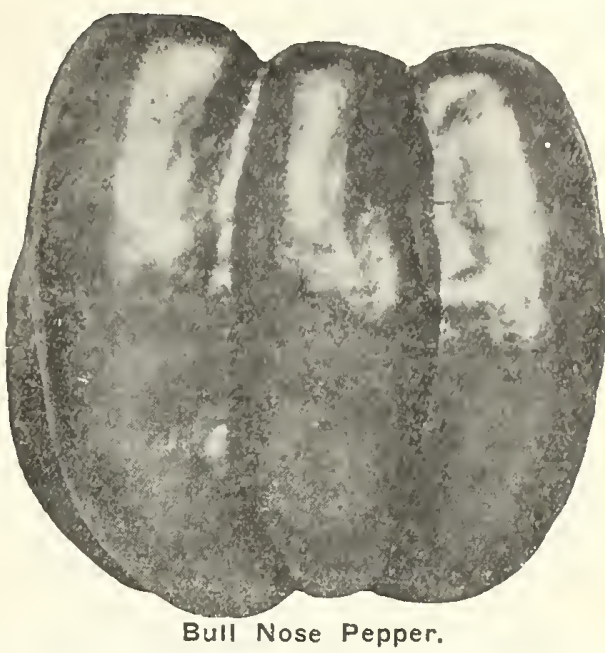

RUBY KING.-Large and handsome Mild flavor. Ruby red color. Can be sliced for salad or fol stuffing or minced pickles. Pkt., 10c; oz., 50c; 1/4 ib., \$1.75, postpaid.

RED CHILI.-A late variety used in the manufacture of pepper sauce. The bright rich red pods are about 2 inches long, $1 / 3$ to $1 / 2$ inch in diameter at the base, tapering to a sharp point, and exceedingly pungent when ripe. Requires a long, prarm season. The plants should be started quite early in hot beds. Pkt., 10c; oz., 50c; 1/4 lb., $\$ 1.75$, postpaid.

\section{PARSLEY}

Culture.-Is easily grown, only it takes several weeks to come pence ground where it is sown is often covered witl weeds or dug over with the belief that seed is no good. Seed may be soaked several hours in warm water before sowing. which hastens germlnation. Sow early in spring in rows a foot apart. Can be used to border beds, making a pretty effect. One ounce will sow a 150 -foot border beds, making a pretty effect. One ounce will sow a 150 -foot
row. Piants can be taken up in fall and put in pots or boxes in a sunny window, and wili continue to furnisin leaves throughout the

DOUBLE CURLED.-An excellent variety for garnishing. Pkt., 10c; oz., 20c; $1 / 4$ lb., 40c; 1 lb., $\$ 1.50$, postpaid.

CHAMPION MOSS CURLED. - Leaves beautifully curled and mossy. Pkt., 10c; oz., 20c; 1/4 lb., 35c; $1 \mathrm{lb}$. $\$ 1.50$, postpaid.

\section{PEANUTS}

MAMMOTH JUMBO.-This variety grows to an aston. ishing size. The plants make compact bushes about 18 inches high, with heavy, erect stalks and large leaves. The giant nuts have thick, heavy-ribbed shells. Lb., 30c; 3 Ibs., $80 \mathrm{c}$, postpaid. Write for prices in quantities.

SPANISH PEANUT.-In addition to their value for growing for the nuts, these are very largely used in the South as a forage and fattening crop for hogs and other stock. They are early to mature, very productive, and in the far South, where they can be planted during March and April, two crops can be made in one year, the second crop being planted early in July, the tops making a hay crop and the nuts a grain crop. This variety frequently yields 60 bushels of marketable peanuts and two tons of hay per acre. 28 pounds to the bushel. Lb., 30c; 3 Ibs., $80 \mathrm{c}$, postpaid.

\section{PUMPKIN}

Culture-Pumpkins wili srow almost anywhere, but rejoice in rich soil. In many varieties the size and weight depend almost
wholly on cuiture and fertility of the land. Many Pumpkins are exceptionally good for pies; other sorts are fit onfy for feeding wrestock. Plant in hills SxS feet. Use $1 / 4$ pound for 75 hills; 3 to 4 pounds per acre. Put seed in ground in May or June, Fight bugs with Bug Death, Slug shot or air-slacked lime.

CONNECTICUT FIELD.--One of the best for field cul ture; can be grown with corn. Is largely used for stock feeding. A deep rich yellow color. Pkt., 10c; 0z., $15 \mathrm{c} ; 1 / 4$ Ib., 30c; 1 lb., 75c; 10 itbs., $\$ 6.00$, postpaid.

CUSHAW.-A prolific variety; large size, frequently weighing 60 pounds and over; color, white striped and mottled with green. Pkt., 10c; oz., 15c; I/4 Ib., 40c; $1 \mathrm{lb}$. $\$ 1.50$, postpaid. 


\section{PUMPKIN-Cont.}

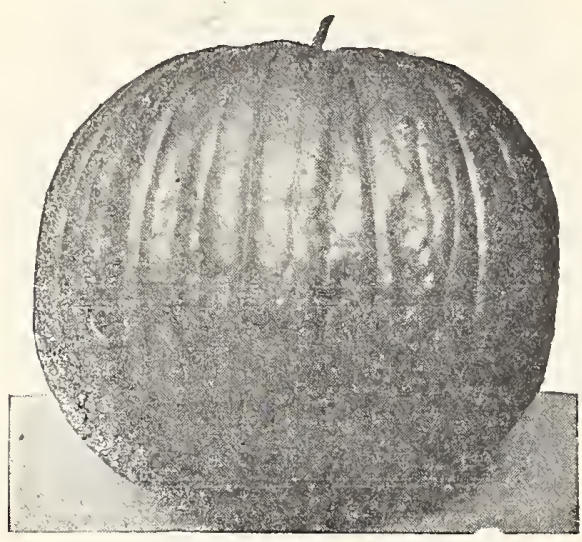

Connecticut Field.

MAMMOTH.-A French variety, which grows to an immense size, often weighing over 100 pounds. Fruit is either long or round, but generally flattened at both ends; skin pale green; marked with deeper bands and marbling. Pkt., 10c; oz., 15c; 1/4 lb., 35c; $1 \mathrm{lb} ., \$ 1.10$, postpaid.

TENNESSEE SWEET POTATO.-Pear-shaped medium-sized Pumpkills, slightly ribbed, or creamy white color and excellent flavor. Pkt., 10c; oz., 15c; 1/4 Ib., 35c; 1 lb., \$1.10, postpaid.

SMALL SUGAR.-Small, round, yellow Pumpkins of excellent quality. An abundant yielder, 8 to 10 fruits often growing on one vine. Pkt., 10c; oz., 15c; 1/4 lb., 40c; 1 lb., $\$ 1.50$, postpaid.

LARGE SWEET CHEESE, OR KENTUCKY FIELD.Very early; large-sized Pumpkins, often measuring 15 inches across top, flat like a cheese and very productive. It is an excellent keeper and is of the finest flavor. Splendid for the table as well as for stock-feeding; also largely used for canning. The skin is orange red. Pkt., 10c; oz., 15c; I/4 lb., 30c; 1 lb., 75c, postpaid; 10 lbs., $\$ 6.00$.

JAPANESE PIE.-The flesh is vely thick, nearly solid. the seed cavity being very small, usually fine. grained, dry and sweet, having much the same taste and appearance of sweet potatoes. They ripen early, keep well, and produce largely. The seeds are peculiarly marked and sculptured in Japanese cliaracters. Pkt., 10c; oz., 15c; 1/4 lb., 40c; 1 lb., \$1.50, postpaid.

LARGE YELLOW.-Most extensively used for feeding stock; also used for making pies. Grows to a large size and varies in shape from nearly round or slightly flattened to quite long. Flesh deep, rich yellow, fine-grained, and highly flavored. Is often planted with corn. It is known also as Field Pumpkin. Packet, 10c; ounce, 15c; 1/4 Ib., 30c; 1 lb., $\$ 1.00$.

\section{RADISH}

6 ounces of seed will plant 100 yards of row; 6 pounds to the acre.

Culture-Cow in ground well enriched with rotted manure. Quality deperids on quickness of growth. The proper temperature is 40 to 65 degrees, Good yentilation is necessary, if grown under glass. Sow seed $1 /$ inch deep in the early spring, in rows 12 to 18 inches apart; for a succession, sow every 10 days. Cultivate frequently. One ounce to 100 feet of dill or 8 to 10 pounds per frequently. One ounce to 100 feet of drill or 8 to 10 pounds per acre. Thin to 1 inch apart for small varieties and 3 to 4 inch
large varieties Rafiahes will mature in from 3 th 5 weelis.

AYRES SCARLET GLOBE.-Twenty days to maturity. A small-leaved variety, well adapted to forcing under glass; root round and carmine colored; early, very attractive and desirable; fine for forcing. Pkt., 10c; oz., $15 c ; 1 / 4$ Ib., 35c; 1 lb., 90c, postpaid.

MARKET GARDENERS' LONG SCARLET.-(35 days.) More largely used perhaps than any other for outdoor planting. Six to 8 inches in length, and possessing all qualities of a fille Radish. Pkt., 10c; oz., 15c; 1/4 lb., 30c; 1 ib., 75c, postpaid.

LONG WHITE VIENNA, OR LADY FINGER.-(25 days.) One of the finest and most popular of the long Radishes, growing 6 to 8 inches in length, beautiful in shape; skin and flesh pure white. Pkt., 10c; oz., 15c; 1/4 Ib., 30c; 1 lb., 75c, postpaid.

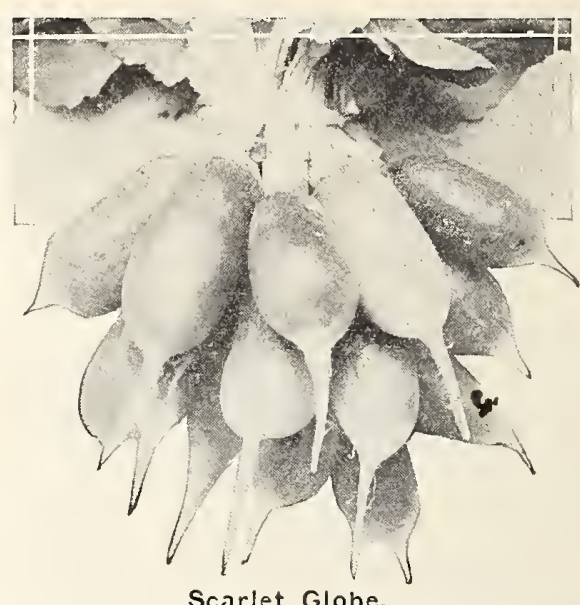

WHITE STRASBURG.-( 30 days. $)$ Of handsome, oblong, tapering shape. Both skin and flesh are pure white. The flesh is firm, brittle and tender, and possesses the most desirable character of retaining crispness even when old and large. Excellent for summer use, and withstands severe heat and grows very quickly. Pkt., 10c; oz., 16c; 1/4 Ib., 35c; 1 lb., 90c, postpaid.

SPARKLER.-A splendid Radish of same type as Scarlet Turnip White Tip, but larger and showing more white, the lower portion being white and upper part deep scar. let. This Radish is not only very showy, but of very finest quality, and sure to become popular with private gardeners as well as growers for market. Pkt., 10c; oz. $15 \mathrm{c} ; 1 / 4$ lb., 30c; 1 lb., 75c, postpaid.

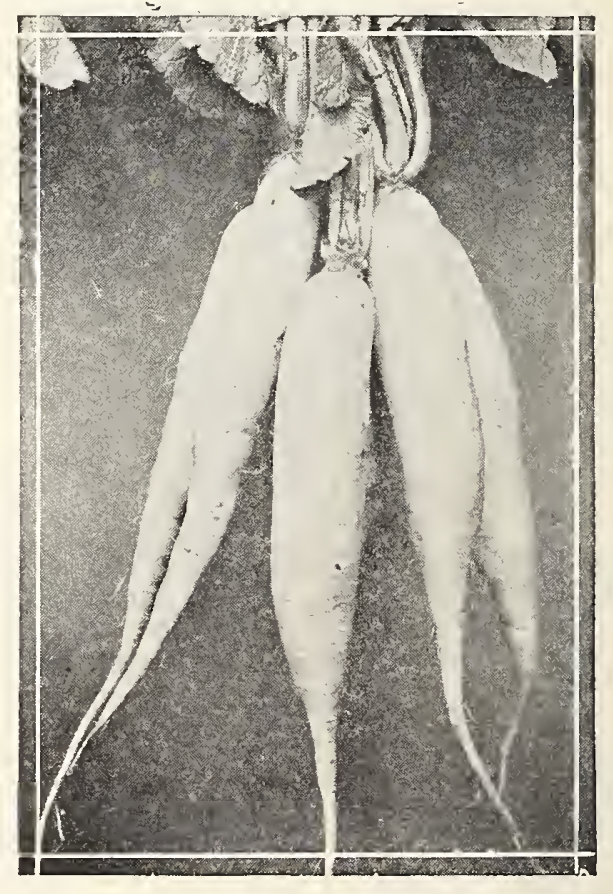

Icicle.

ICICLE.-(30 days.) The finest, most delicate. and tenderest of pure white Radislies. About $\mathbf{6}$ inches in length, clear transparent white, crisp and tender; very attractive on the table and also for the market; ready to pull three weeks after sowing; may be sown as early in spring as soil can be prepared. Remains tender and free from pith for longer period than any other sorts; attractive in appearance and extremely early. Pkt., 10c; oz., 15c; $1 / 4$ lb., 30c; 1 lb., 75c, postpaid.

FRENCH BREAKFAST.-( 25 days.) A small, handsome variety of very quick growth; $1 / 2$-inch in diameter and 2 inches long. Pkt., $10 \mathrm{c}$; oz., $15 \mathrm{c} ; 1 / 4 \mathrm{lb} ., 30 \mathrm{c}$; $1 \mathrm{lb} ., 75 \mathrm{c}$, post.nair 


\section{RADISH-Cont.}

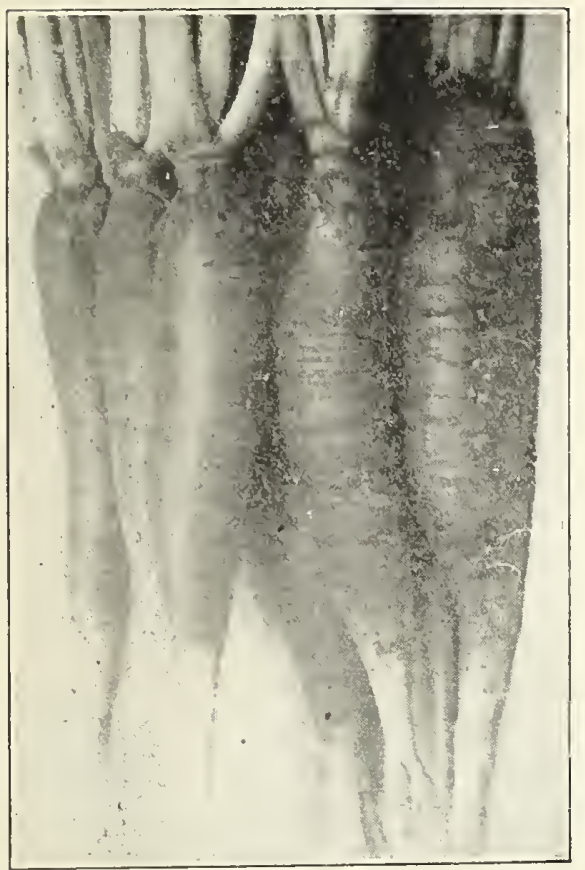

Long Bright Scariet.

EXTRA EARLY SCARLET TURNIP.-(20 days.) A small, round. red, turnip-shaped Radish, with a small top; of very quick growth. A very early variety. deserving of very general cultivation on account of its crisp and tender qualities. Pkt., 10c; oz., 15c; $1 / 4$ lb., 30c; 1 lb., 75c, postpaid.

EARLY SCARLET TURNIP, WHITE-TIPPED.- $(18$ days.) A beautiful variety, deep scarlet with white tip. It is very ornamental for table use and is becoming very popular as a market variety. It is of the same size and shape as the Scarlet Turnip variety. Pkt., 10c; oz., 15c; 1/4 lb., 30c; 1 ib., 75c, postpaid.

HALF-LONG DEEP SCARLET.-(25 days.) Same form as Long Scarlet, but only half as long. Pkt., 10c; oz., $15 c ; 1 / 4$ lb., 35c; 1 lb., $90 c$, postpaid.

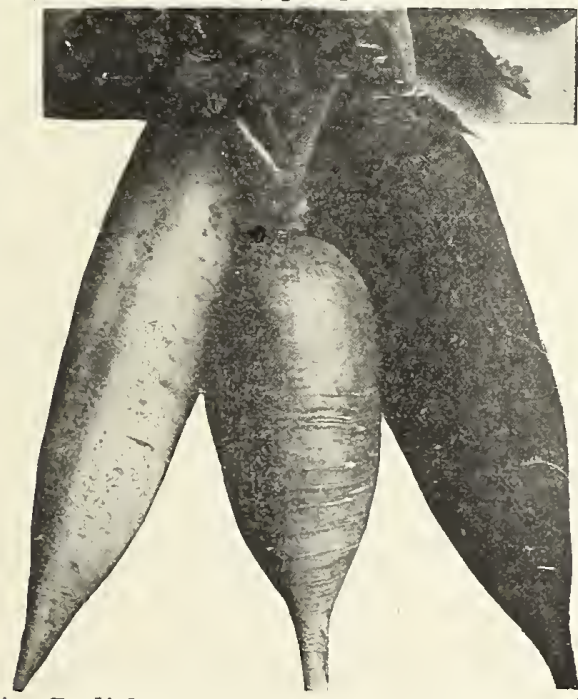

Winter Radishes-

Pkt

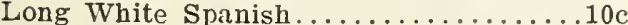

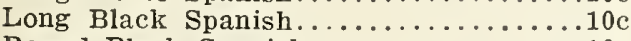

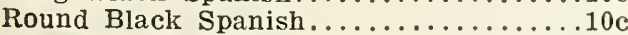

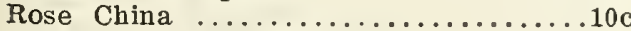

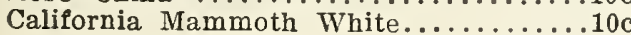
Rose Turnip Radish...............10c

\section{RHUBARB OR PIE PLANT}

Culture.- This is of hardy growth everywhere and one of the first sauce and pie plants of early suring. It is sown elther from seeds or propaction made made extremely rich, uslng manne every other season. The seerl mould extremely rich, un the mand 1 vate throubout the plants out to stand o inches apart and cultiplants the southwest the plants get large enough to use in the fall from seed sown the pievious spring. The roots should be planted 3 feel apart in the ance of seed will sow 100 feet of dilll.

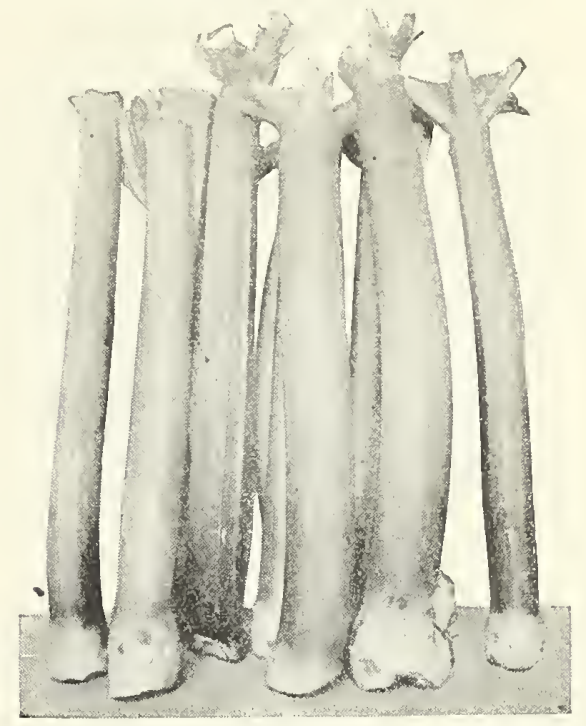

Queen Victoria.

QUEEN VICTORIA.-This is one of the newer $\mathrm{Pa-}$ rieties, and in some locations is very popular, being a bright pink. A splendid variety. Pkt., 10c; oz., 20c; 1/4 lb., $50 \mathrm{c} ; 1$ lb., $\$ 1.75$, postpaid.

LINNAEUS.-Large and tender. The very finest of all. Pkt., 10c; oz., 20c; 1/4 ib., 50c; 1 lb., $\$ 1.75$, postpaid.

Prices on application.

RHUBARB ROOTS.

\section{RUTABAGAS}

Culture.-Tutabagas, $\mathbf{S}$ wedish or Russian Turnips, are exten. sively grown for a farm crop. The roots are close-grained, hard, and will endure a considerable degree of cold without injury if preserved in a pit or cellar during the winter. Rutabagas are superior to any other vegetable root grown for cattle, horses and sheep. The animals thrive and fatten on rutabagas, carrots and mangels fed ln combination with liay.

AMERICAN PURPLE TOP.-A very large, globe. shaped Rutabaga, yellow with purple top. Hardy, vigorous. growing variety of excellent quality for the table and one of the best for stock feed. Pkt., 10c; oz., 15c; $1 / 4$ Ib., 35c; 1 Ib., 75 c; 5 ibs., $\$ 3.00$, postpaid.

\section{SALSIFY OR VEGETABLE OYSTER}

Culture.-Soil and culture should be the same as for Parsnips, taking pains to make sowings as early as practicable each spring. Salsify is boiled like Parsnips or Carrots, or is half-bolled and grated, then made up into balls which are dipped into batter and fried like oysters. Sow in drills about 18 inclies apart, and thin the plants to 3 inches in the row.

MAMMOTH SANDWICH ISLAND.-A new and improved type, producing roots of nearly double the size and weight of the old sort, and in every way preferable. Much valued by market gardenel's, as it grows stronger and is less inclined to branch. Pkt., 10c; oz., 20c; 1/4 Ib., 60c; 1 lb., $\$ 2.00$, postpaid.

\section{SQUASH}

1 ounce of early varieties will plant about 40 hills; 1 ounce of late varieties will plant about 20 hills; 3 to 4 pounds to acre. 


\section{SQUASH-Cont.}

Culture.-Ahout the same as Melons. Make the ground very rich. A good sandy loam is best. The Squashes ars all tender, and the seed should not be planted until warm weather. Allow $4 x 4$ feet for the hills for the bush Squashes and $8 \times 8$ feet or more for the running varieties. Four plants to the hill. 3 tet or more for the co the acre. For summer squashes estimate 2 ounces to 100 see cor winter Sruashes, 4 ounces to 100 hills.

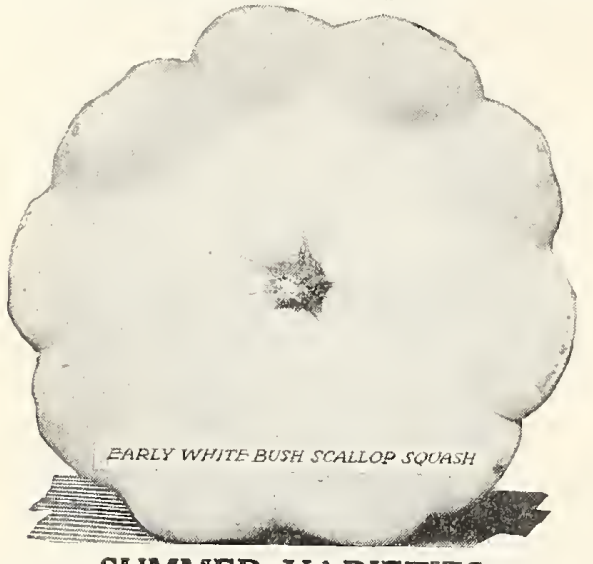

SUMMER VARIETIES

MAMMOTH WHITE BUSH SCALLOP.-This variety is about twice the size of the White Bush Scallop and much whiter and handsomer. Pkt., 10c;oz., 20c; 1/4 Ib., $50 \mathrm{c} ; 1$ Ib., \$1.50, postpaid.

GOLDEN SUMMER CROOKNECK.-This variety of Summer Crookneck, we find, grows twice as large as the common sort, averaging from 5 to 6 pounds in weight. Pkt., 10c; oz., 20c; 1/4 lb., 50c; 1 lb., \$1.50, postpaid.

THE GRAND SQUASH, DELICIA HUBBARD.-A cul. inary joy. A Delicia pie or baked Delicia is a very tooth. some morsel. Pkt., 10c; oz., 20c; $1 / 4 \mathrm{lb} ., 50 c$; $1 \mathrm{lb} ., \$ 1.75$, postpaid.

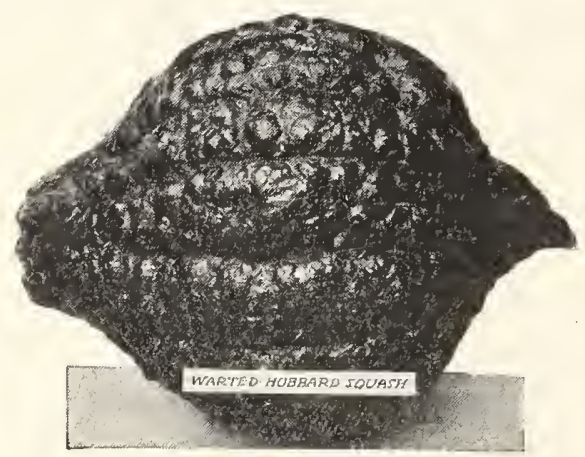

\section{WINTER VARIETIES}

WARTED HUBBARD SQUASH.-This variety is a great favorite with the marketmen. It is very striking in appearance and has been selected for years from exceptionally large specimens. It crops heavily. Our crop last season was at the rate of 10 tons per acre. It grows to nearly double the average size of the common Hub. bard. Our strain was obtained from a market gardener famous for his warty Hubbards. It sells in the market better than those having smooth shells. Pkt., 10c; oz., 20c; 1/4 Ib., 50c; 1 lb., $\$ 1.30$, postpaid.

FORDHOOK.-Fine grain; very sweet and productive; can be used at any time of their growth; skin very thin; good keeper. Pkt., 10c; oz., 20c; 1/4 Ib., 50c; 1 lbs, $\$ 1.75$, postpaid.

\section{SPINACH}

1 ounce will sow 150 feet of drill; 1 to $1 \frac{1 / 2}{2}$ pounds to the acre.

Culture.-For early spring use, sow seed in August or September in rich soil. Upon approach of cold weather, cover the plants with 3 inches of straw or soft hay. In the spring, when dry, remove litter and plants will be ready for use in a short time. Sow seed 1 inch deep in rows 1 foot apart or broadcast For a succession, sow every two weeks from April to June. Use 1 ounce to 100 feet of drill, 8 to 10 pounds per acre in drills, 15 to 18 pounds broadcast.

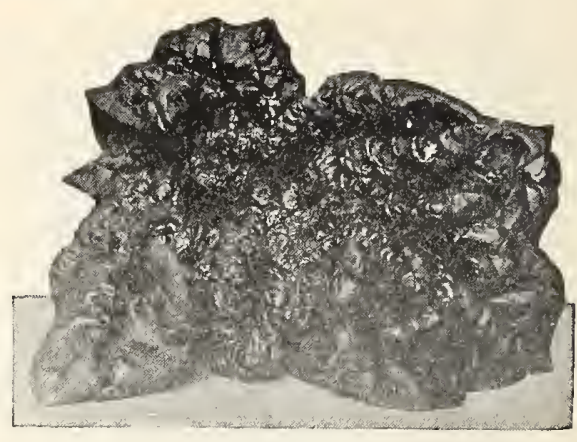

Bloomsdale.

GIANT THICK-LEAVED.-An early variety; very hardy and of good quality. Large, round leaves, nearly smooth, of dark green color; favorite with market gardeners. Oz., 10c; $1 / 4$ lb., 20c; 1 lb., 50c; 10 lbs., \$4.00, postpaid.

VICTORIA.-Large, very dark green leaves, slightly crimpled. In good condition for market for a long time. A newer variety that is very popular with the truckers. Planted extensively in South. Oz., 10c; 1/4 Ib., 20c; 1 lb., $50 \mathrm{c}$, postpaid.

BLOOMSDALE, OR SAVOY-LEAVED.-Of upright growth; leaves curled and crimpled, thick and fleshy. Keeps well after cutting. Suitable for fall sowing. Oz, $10 c$; $1 / 4$ lb., 20c; 1 lb., 50c; 10 lbs., $\$ 4.00$, postpaid.

NEW ZEALAND.-A different type of Spinach, suitable for use during the hot weather. Plants grow to a large size, producing an abundance of leaves, tender and of good quality. Oz., 15c; $1 / 4 \mathrm{lb} ., 35 \mathrm{c} ; 1 \mathrm{lb}, 90 \mathrm{c}$, postpaid.

\section{TURNIP}

1 ounce will sow 150 feet of drill; 2 to 3 pounds to the acre.

Culture.-The value of Turnips and Rutabagas for feeding stock in fall and winter is not fully appreciated, as they ars much liked by all kinds of stock and serve to keep them in good condition. They should not be fed, however, in large quantities to mllch cows, or the flavor of the milk will be disagreeably affected. We recommend that farmers increase their sowings largely, for we are sure the crop will prove remunerative for stock feeding as well as for table use when the roots are comparatively small. These wholesome vegctables are very easily affected in their form and flavor by soil, climate and mode of culture. The Turnip plant is distinguished from the Rutabaga by its rougher leaves, the root usually matures earlier and is smoother. For summer use, sow early in spring a light, rich or new soil, in drills $1 \frac{1 / 2}{2}$ to 2 feet apart, according to the size of the variety, and cover $1 / 2$ inch deep, or sow broadcast, but in elther case be sure to have the ground rich and freshly stirred. Thin early and keep free from weeds, so that the young plants will not be checked in growth. Any overso that the young plants will not be checked in growth. Any overportant to get the spring and summer crop started very early, portant to get the spring and summer crop started very early, so that the Turnips may have time to grow to sufficient size before hot weather causes them to become tough and biter. In the middle of June to the first of August and in the manner given the middle of June to the first of August and in the manner given for spring sowing. In the field, Turnips are often sown broadcast, though in most cases better results are obtained by drill culture; burned rover land where the weeds are not likely to be troublesome.

PURPLE TOP WHITE GLOBE.-(65 days.) Large size. rapid growth, unusually attractive. A much heavier producer than the preceding. We confidently recommend it. No sort is its superior. Will produce more tons to the acre than any other sort. Pkt., 10c; oz., 15c; 1/4 Ib., 25c; 1 lb., 60 c; 10 Ibs., $\$ 6.00$, postpaid.

COW-HORN.-A delicate and good flavored sort, and in favor both in the market and family garden. A distinct feature is its rapid growth. Is pure white, except a dash of green at crown, and is long like the carrot and crooked, hence its name. Pkt., 10c; oz., 15c; 1/4 Ib., 30c; 1 lb., \$1.00, postpaid.

EXTRA EARLY WHITE MILAN.-(45 days.) Similar to preceding, except skin is pure white, making it desirable for forcing. Pkt., 10c; oz., 20c; $1 / 4 \mathrm{lb} ., 30 \mathrm{c}$; $1 \mathrm{lb}$., $\$ 1.00$, postpaid.

PURPLE TOP (Strap Leaved).-(55 days.) The standard for this section. Superinr for early or late planting. Round, flat, good-sized, small top, few leaves. Flesh very fine-grained; flavor good. Pkt., 10c; oz., 15c; $1 / 4$ Ib., 


\section{TURNIPS-Cont.}

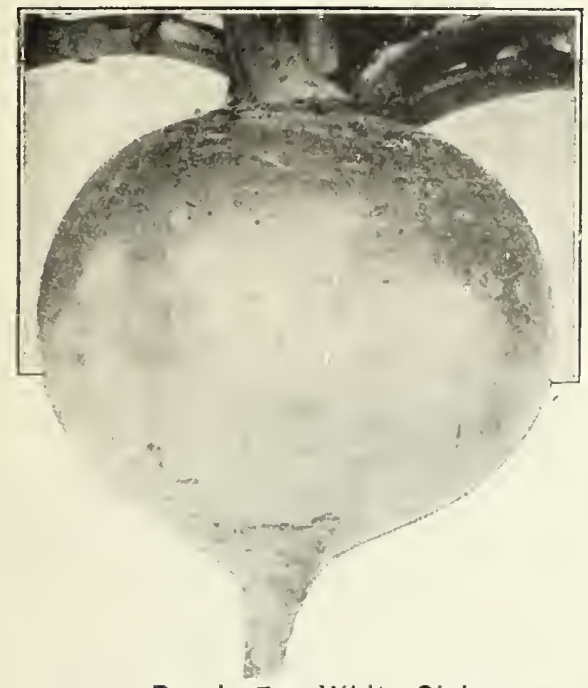

Purple Top White Globe.

YELLOW GLOBE.-A round, smooth, light yellow Turnip of medium size. The flesh is crisp, firm, and of very good quality for the table or for stock-feeding. The roots are in best condition for table use when 3 to 4 inches in diameter. This sort keeps well and is a good cropper. Pkt., 10c; oz., 15c; 1/4 Ib., 30c; 1 lb., 75c, postpaid.

\section{TOMATOES}

Tomatoes do best on light, warm, not over-rich soil, and success depends upon securing a rapld, vigorous and unchecked growth during the early part of the season. Sow in hot-bed or in shallow boxes In the house from 6 to 8 weeks before they can be set out of doors which ls when danger from frost is past. when the plents have dis lants have setting them 40 in and endeavor to secure a vigorous but steady and healthy growth, so that at the time of setting in the open ground they will be strong and stocky. Even a slight check whlle the
diminish thelr productiveness.

Set out of doors as soon as danger from frost is over, but before doing so harden off the plants by gradually exposing thein to the night air and by the withdrawal of water untll tho woov becomes hard and the leaves thlck and of a dark green color. Transplant carefully and cultivate well as long as the vines will permit. If to be grown without training, the plants are usualiy set from 3 to 4 feet apart each way, according to the vigor of the variety.

To Insure best results in respect to early ripening, as well as the amount and perfection of fruit, it is advisable to train up and trim the vines, especially if the patch is rather small. When the plants have been properly started and are 6 to 10 lnches high they will begin to throw out branches. Select the largest and most vigorous of these and pinch off all others except thls one and the main stem. Care must be exercised not to pinch off the fruiting main stem. Care must be exercised not to pinch off the fruiting that are formed very early. In a short time these two remaining that are formed very early. In a short time these two remaining will grow 4 to 6 feet high during the season. they should be will grow 4 to 6 feet high during the season. they should be
securely tied at intervals of about 10 inches to a long stake, prefer ably 2 inches square, which has been securely set in near the root of the vine

Fruit will set to almost any height desired if all side branches are kept trimmed off at intervals of a week. By such a method of training and trimming the fruits are kept clear from the ground and with free access of sunlight they ripen much earlier: the vitality, otherwise exhausted in superfluous leanches and leaves, is utilized in forming fruits of largest size, greatest perfection of shape and best quality. For cultural directions, see books listed on inside of back cover.

Cuiture.-This vegetable, under proper cultivation, is wonderfully productive hoth as to quantity and quality. In this section of the country it is more largely used in canning than any other of the country it is more largely used in canning than any other vegetable and should have a place in every garden. One ounce or March in hot-beds or boxes, which should be placed near a or March in hot-beds or boxes, which should be placed near a window. When the seedlings are 2 to 3 inches high, transplant Into 2 or 3 -inch pots or in rows 4 or 5 inches apart, keeping the
temperature about 60 degrees Subsequent transplanting will make the plants strong and hardy. Do not set them in the open ground until all danger of fros: is nver

BEAUTY, IMPROVED STRAIN.-A standard Varlety for many years, and is still the favorite main crop Tomato with market gardeners. Medium early, round. very uniform in shape. Skin smooth, crimson with purplish tinge. Flesh solid and of excellent flavor. A splendid Tomato for either home garden or for shipping. Pkt., 10c; oz., 30c; 1/4 Ib., 90c, postpaid.
THE NEW STONE.-The Tomato for the main crop. Choicest seed. We call this the king of the Livingston kinds, whicll are the best types of large, smooth, solld, "beefy" Tomatoes. If asked to select one main crop market sort, we advise this. Color fine scarlet, stem set high, core small and sliallow, so that little is lost when it is taken out of the fruit before slicing. If in doubt, buy the New Stone for market or home use. Pkt., 10c; oz. $30 c ; 1 / 4 \mathrm{lb} ., 75 \mathrm{c}$, postpaid.

DWARF STONE.-(100 days.) Fruit like Improved Stone. The strong upright growth allows very close planting. The planes may be set 18 by 24 inches apart and yet produce an abundant crop. Pkt., 10c; oz., 30c; 1/4 lb., 90c; postpaid.

MATCHLESS.-(100 days.) A large, bright red To mato; very popular in the East. Fruit is large, smooth and synmetrical, ripeling well to stem. Flesh is of a rich red color and fine quality. Pkt., 10c; oz., 30c; 1/4 lb., 75c; postpaid.

TRUCKERS' FAVORITE.-(90 days.) Purple-fruited, excellent quality, good size, maintained until late fall. Fruits are smooth, solid, and flesh is finest color. Unexcelled for slicing or cooking. Plants thrifty, free from rust or blight, and bear until killed by frost. Pkt., 10c; oz., 30c; 1/4 Ib., 90c, postpaid.

ACME.-(100 days.) An old-time popular variety, having at all times given entire satisfaction. Round, smooth, purple. Pkt., 10c; 0z., 30c; 1/4 lb., 90c, postpaid.

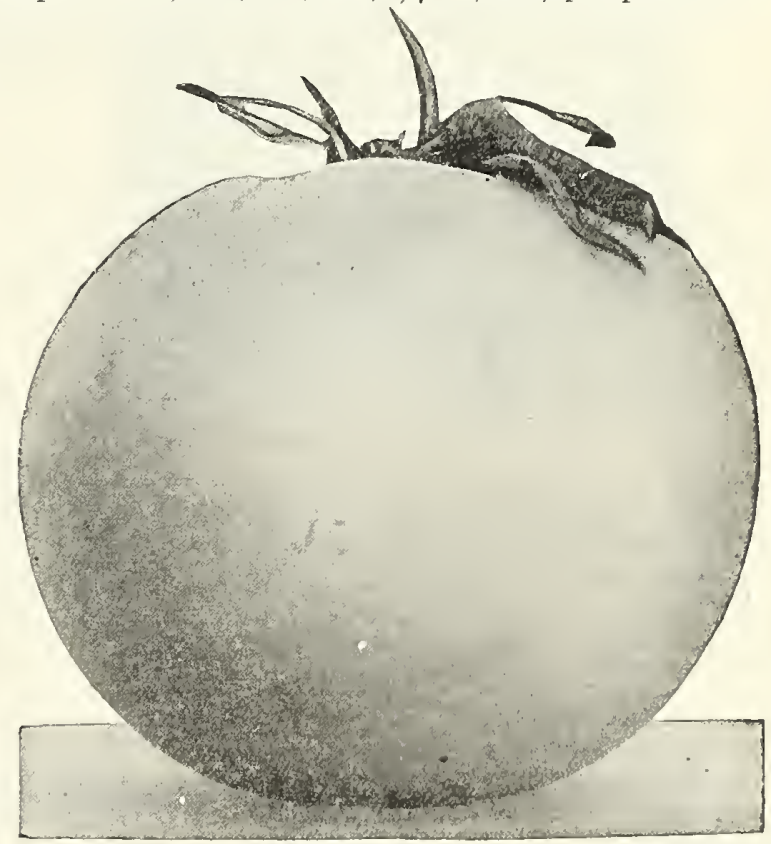

Improved New Stone.

JOHN BAER.-Largest fruited, smoothest and finest in quality of the extra early Tomatoes. Vines short, vigorous and enormously productive. They ripen a larger crop in the early part of fruiting season than any other extra carly variety. Fruits globular, uniform and smooth; freo from wrinkled, cracked fruits. Color is a bright scarlet. Fruits have no hard core; small seed cells, and practically all meat of mild and sweet flavor. Pkt., 10c; oz., 30c; $1 / 4$ lb., 90c, postpaid.

SPARKS' EARLIANA.-(90 days.) Fruit of large size, handsome shape and color; in solidity and quality equal to any; has proven very remunerative to growers for market; zrows in clusters of 5 to 8 fruits; ripens clear to the stem and does not crack. Pkt., 10c; 0z., 40c; 1/4 lb., \$1.00, postpaid.

FAVORITE (Livingston's).-Ripens evenly and early; very prolific; good flavor; few seeds; flesh sound. Pkt., 10c; oz., 30c; 1/4 lb., 90c, postpaid.

BONNY BEST.-An caily and nodnctive variety. Fruits aro round. solm what f'attnned at stem end, and are produced in abundare. Tho color is scarlet. and it is a good forcing Tomato. Pkt., 10c; oz., 30c; 1/4 ib., 90c, postpaid. 


\section{TOMATOES-Cont.}

GOLDEN QUEEN (Queen of the Yellows).- $(100$ days.) Solid, smooth, large in size, and ripens early. Makes a hand some, rich preserve. This Tomato should be grown in every home garden. Its flavor is better and more delicate than that of the red varieties, the flesı linerslained and very tender. Try it. Pkt., 10c; oz., 30c; 1/4 ib., $90 \mathrm{c}$, postpaid.

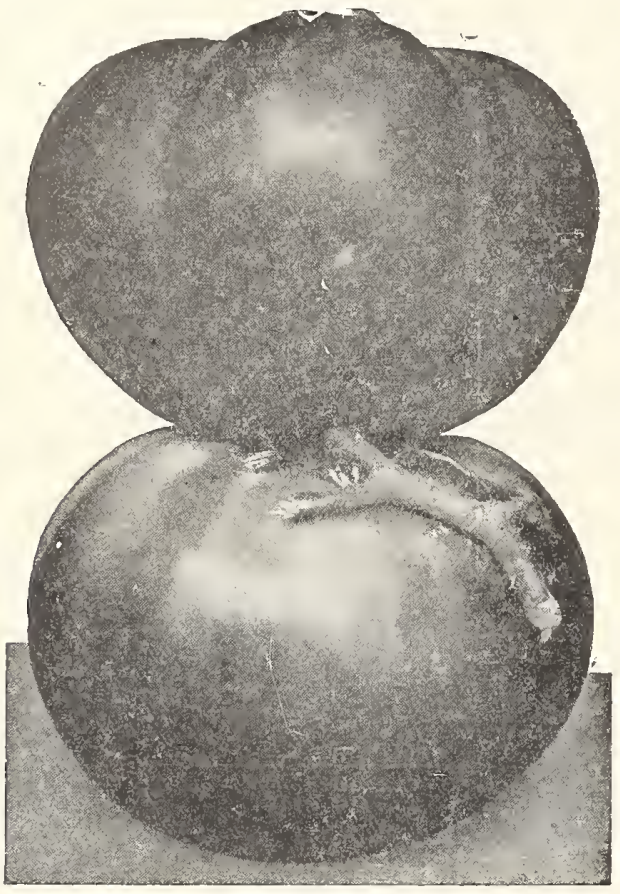

Dwarf Champion.

JUNE PINK.-(90 days.) A purple-pink selection from Earliana. The fruit is smooth and the plant a good yielder. Pkt., 10c; oz., 30c; $1 / 4$ lb., 90c, postpaid.

PONDEROSA.-(120 days.) Purplish-pink Tomato of the largest size. Very meaty, few seeds, and free from acid. Ripens mid-season. Pkt., $10 \mathrm{c}$; oz., 40c; 1/4 lb., $\$ 1.25$; postpaid.
DWARF CHAMPION.-Sometimes sold as the "Tree Tomato." A second early or main crop, purplish pink variety; desirable where garden space is limited. Vines are about 2 feet high, vigorous, upright, compact. Fruits medium-sized, smooth and of very good quality. Our stock is a superior strain with more even. smoother fruit than the original. Pkt., 10c; oz., 35c; $1 / 4$ lb., $\$ 1.10$, postpaid.

PEACH.-For preserving or table decoration; fruits resemble a peach in shape and size and the color is light terra cotta red, with a delicate bloom: Flesh is tender and good flavor. Pkt., 10c; oz., 45c: 1/4 lb., \$1.50, postpaid.

\section{SMALL-FRUITED 'TOMATOES}

Very delicious for preserving. Vines immensely productive.

YELLOW PEAR. - Fruits similar to the Red Pear, but of' rich, clear, yellow color, and quite distinct from the variety sometimes sold under this name. Pkt., 10c; oz., 45c; 1/4 lb., \$1.50, postpaid.

YELLOW PLUM.-Fruits plum-shaped, of clear. deep yellow color; flesh yellow and finely flavored. Esteemed for preserves. Pkt., 10c; oz., 45c; $1 / 4 \mathrm{lb}$., $\$ 1.50$, postpaid.

RED CHERRY.--Fruits small, about $5 / 8$-inch in diam. eter, perfectly round and smooth. Fine for pickles and preserves. Pkt., $10 \mathrm{c}$; oz., $45 \mathrm{c} ; \mathrm{l} / 4 \mathrm{lb}$., $\$ 1.50$, postpaid.

YELLOW CHERRY.-Differs from Red Cherry in color only. Pkt., 10c; oz., 45c; $1 / 4$ lb., $\$ 1.50$, postpaid.

YELLOW HUSK, OR GROUND CHERRY.-Very sweet, mild flavor; used for preserves. Vines low and spreading. Fruits small, about $1 / 2$-inch in diameter, enclosed in a loose husk. The seed we offer is that of the true Yellow Ground Cherry. Pkt., 10c; oz., 45c; 1/4 lb., $\$ 1.50$, postpaid.

\section{TOBACCO}

HAVANA.-From pure Cuban grown seed. When grown in this country commands a high price for cigar stock. Pkt., 10c.; oz., 40c, postpaid.

MISSOURI BROAD LEAF.-Extensively grown in Kansas and Missouri; the large broad leaves are used for the wrappers. Pkt., 10c.; oz., 40c, postpaid.

WHITE BURLEY.-Largely used for the manufacture of cigars, as the leaf of this variety readily absorbs a large quantity of manufacturing material. Pkt., 10c; oz., $40 \mathrm{c}$, postpaid.

\section{VEGETABLE PLANTS}

EARLY CABBAGE PLANTS.-For delivery in April and May.

SWEET POTATO PLANTS.-All the leading varieties. TOMATO PLANTS.-Ready in May and June.

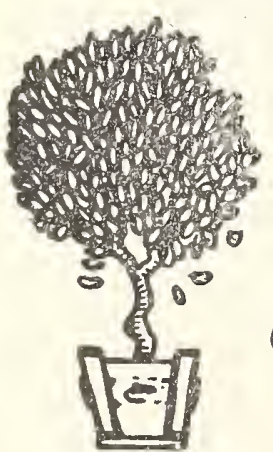

"Over 100 Acres in Flowers"

\section{THE UPTOWN STORE}

On Petricoat Lane

Eleventh Street at McGee

for

Cut Flowers, Plants, Shrubs and Ornamentals, fresh every day from our own greenhouses

\section{Bryson Ayres Flower Store Phone, VIctor 7591}




\section{FARM SEED SECTION BRYSON AYRES FIELD AND GRASS SEEDS Are Recleaned, Tested and Certified}

At the time this Catalog goes to press prices are so unsettled that it is impossible to print all of them.

\section{SEED CORN}

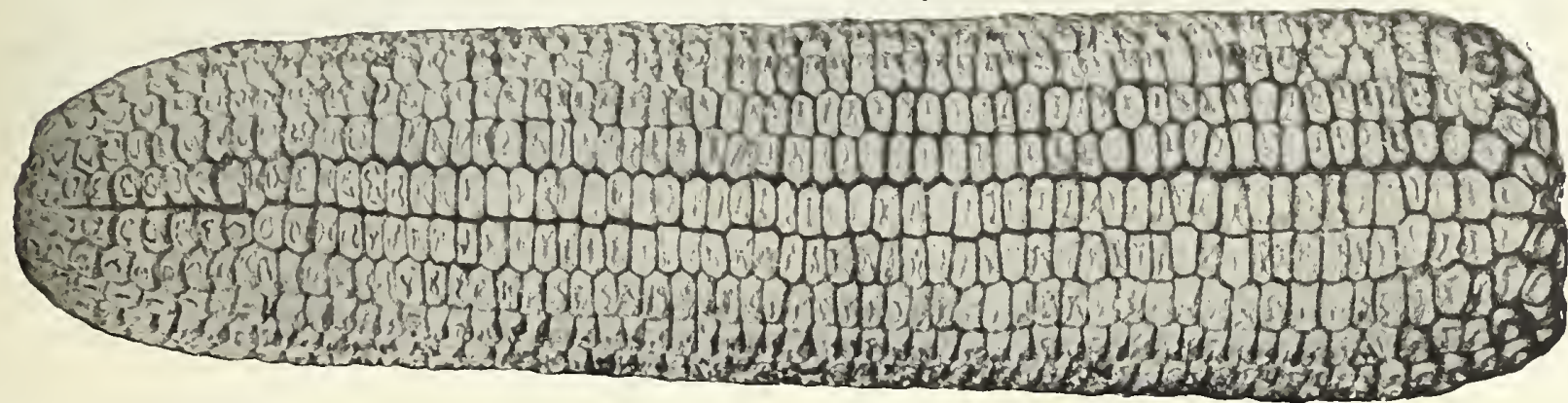

We have been able to secure Seed Corn of excellent quality, and the test shows high germination. We will be able to furnish the following varieties of good quality until our stock is exhausted. Prices subject to change without notice.

\section{SELECTED SEED CORN}

\section{HAND-PICKED, NUBBED AND GRADED}

IMPROVED GOLDEN BEAUTY.-(110 days.) We know of no other variety that will give better satisfaction than the big. handsome Golden Beauty. It is the largestgrained Dent Corn in cultivation. Ear is perfect in shape, with 10 or 14 lows of golden yellow grains; cob small, and is sure to please every farmer who grows it. The heaviest cropper we have handled. Prices on application. REID'S YELLOW DENT.-(110 days.) Thoroughbred, pedigreed, carefully selected stock. During the past five or six years this variety has come rapidly to the front and now occupies a prominent position in all lists. It is of handsome shape and color, and largely grown for exhibiting at fairs, Corn shows, and is used in many Corn schools as a standard for judging. We have selected the choicest ears, so that we are sure our seed cannot fail to please the most particular. Handsome yellow color. smooth, deep-grained, and kernels packed very closely on cob, giving it an appearance of great solidity. Matures in about 115 days. Prices on application.

IOWA SILVER MINE.- - Iowa Silver Mine is standard. It is well and favorably known. A remarkable drouthresister, and under adverse conditions seems to pull through and make a crop where other varieties fail. Silver Mine is deep-grained, pure white, rough-topped, with a small white cob. Ears from 9 to 12 inches long, with 16 to 2n rows of pure white kernels, solidly set on ears; well filled out at butt and tip. This Corn is a drouth-resister, maturicg in hot climates where early drouths are frequent. Stalks medium height, very leafy, with broad blades, frsGuently bearing two ears weighing 1 to $1 \frac{1}{2}$ pounds ear.h. Iowa Silver Mine has taken as many sweepstakes and first premiums as any Corn. The pure-bred Silver Mine is a safe crop anywhere in the corn belt and in all the Southern States, including Missouri. Kansas, Oklahoma, Texas, Arkansas, Louisiana, Mississippi, Alabama, Georgia, Tennessee, Kentucky and Virginia. Matures in 100 days.

IOWA GOLD MINE.-Is not a large Corn, but the best thing we know of for medium early. We offer the pure strain Gold Mine, and recommend it. With the expert corn farmers, Gold Mine is known as medium earlybetween the 110-day and the extra early sorts that mature in 85 days. It is, however, a great producer and sure cropper. Ears are medium and symmetrical. Color, bright golden yellow. The grain is deep, and the cob is small; for this reason it dries out quickly, producing 62 to 63 pounds of shelled corn to 70 pounds of ears. Stalks make exi $\in$ llent silage or fodder. Iowa Gold Mine will grow in nearly every State and is specially recommended for the Western corn belt. Throughout the Eastern States, where climate does not demand an extra early variety, it is very popular. Tried all over the South with nothing but best results.

BLOODY BUTCHER-Color, deep cherry-red with white cap, generally 14 rows of pure red, white cap corn on a small cob. Long, slender ears, 8 to 10 inches. Stalks medium height, fairly heavy, grains always dented and sometimes rough. As White Cap Red Butcher will mature in 90 days, it is planted for husking crop throughout the North Corn Belt as far up as St. Paul, Minn. The same conditions exist throughout the Middle West and on east to New York and the New England States. Finds many friends for late planting in Iowa, Illinois and Eastern Nebraska. Great favorite in Missouri, Kansas, Oklahoma and Texas for early feeding. Matures in 85 to 90 days.

WHITE PEARL.-An extra early pure white variety of the Dent family; very productive and exceedingly heavy, maturing in 5 to 90 days from the time of planting. The grains are extra deep and wide, two of which will more than span the cob, which is small; also largely used for roasting-ears. Prices on application.

ST. CHARLES RED.COB WHITE.-Pure white corn with red cob, ears large, moderately rough, deep grain. Stalks grow leafy and heavy and will produce enormous yields of Corn for husking crop or for silage. It is a native of St. Charles County, Missouri, best adapted to the Southern States for a husking corn and is in great demand in the Eastern and Northern States for ensilage and fodder purposes.

BOONE COUNTY WHITE.-(110 to 120 days.) A very large white Corn, something like Silver Mine, but larger and later in maturing. It is a native standard variety in Illinois. Boone County is peculiarly suited to all the Southern States, as it ripens earlier than the native Corn and will not be forced ahead too rapidly, owing to its slow-growing tendencies. Ears well filled out at both ends, cylindrical, 9 to 11 inches long, averaging twenty rows, some eighteen and twenty-two. Grain very deep, a little rough. Cobs white, of medium size. Boone County is a show Corn, and has carried off many premiums offered at Corn contests, State and county fairs. For the southern half of Iowa and localities that do not lie farther north; southern Illinois and Nebraska, Oklahoma, Missouri, eastern Kansas, Texas, Arkansas, Louisiana, Mississippi, Alabama, Georgia, Tennessee, Kentucky and Virginia 
Write for Prices and Samples.

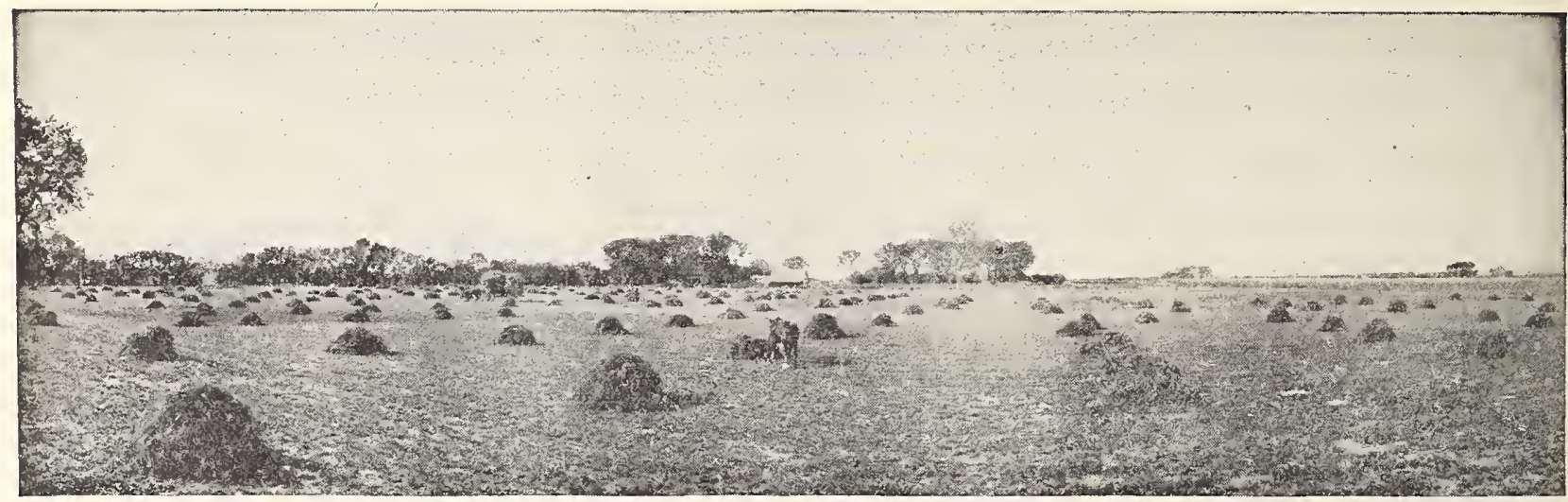

\section{CERTIFIED ALFALFA SEED.}

Pursuant to our policy of protecting the customer wherever possible, we have gone to the expense of having our seed tested for germination and purity and of marking each sack with a tag or certificate showing results of such test and giving purity and germination of seed contained therein. This we guarantee to be correct.

\section{THE BEST OF ALL PLANTS FOR HAY AND PASTURE}

Alfalfa, the most valuable forage plant ever discovered, was first tound in Asia, but its present wide distribution throughout the world indicates a remarkable adaptability to various soils and climates.

Alfalfa is a soil-builder, and not a soil-destroyer. The roots often reach the length of 15 feet. This penetration not only locsens the soil for the roots of the next crop. but brings to the surface the phosphorus and potash stored below.

PLANTING.-If broadcasting, three ways: With a wheel-barrow seeder, an end-gate seeder, or by hand.

If any of the these three ways are used, harrow lightly immediateiy following planting. If the ground is disced lightly before planting, leaving it a little rough, the seed will be easier covered than if the surface is smooth.

Drilling is best, as it distributes the seed evenly, put. ting them where needed, causing less waste and putting them at a uniform depth. Do not place the seed too deep in the soil, $3 / 4$ to 1 inch is usually sufficient.
TIME OF PLANTING.-Spring and fall planting are equally successful, a great deal depending on the season and climatic conditions. When spring seeding is practical we advise sowing as early as possible, after frost is out of the ground, as there is less danger from freezing out than llom losing a stand due to warm, dry weather or choking cut with weeds.

SEED.- When buying Alfalfa, you want the best and purest seed obtainable. Cheap grades are apt to contain Sweet Clover, Yellow Trefoil, Burr Clover, Dodder, etc. We handle the best hardy, non-irrigated stock, for it has much stronger vitality than irrigated or foreign seed and gives better results.
Ayces Certified Alfalfa .............Per 100 lbs

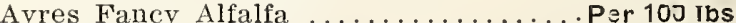
Ayres Choice Alfalfa .................... 100 lbs.
Ayres Prime Alfalfa ...............Per 100 lbs.

GRIMM ALFALFA.-It is positively the hardiest Alfalfa seed on the market. The strong branching roots of Grimm prevent winter killing as in common ordinary Alfalfa. These same roots which grow in time 6 to 20 feet in length and as thick as a man's wrist provide drought resistance and unusual productiveness.

Again these great roots make humus whon ploughed in to the soil, and this humus conserves moisture, thus preparing the soil for whatever subsequent crop might call for it. Grimm Alfalfa plants are extraoldinary soil fertilizers. We offer to send a free sample to you and to any friends of yours who you think would be interested in the purchase of Grimm Alfalfa seed.

\section{CLOVER}

\section{Write for Prices and Samples.}

SWEET CLOVER-(White Blossom.) This is the variety most commonly found and the one in greatest demand. It is the variety that is grown so extensively as a cultivated crop and the one so much in demand. The White Blossom Sweat Clover is destined to become the most important of tle legumes and will add millions to the wealth of the farmers of this country.

The great value of the plant is now realized, as it excels Alfalia as a pasture crop and will produce more tons of hay per acre than Alfalfa, the hay being fully equal in feed value. Its greatest value as a money crop is unquestionably in the seed crop. Sweet Clover will produce a heavy crop of hay the first year; the second year you can harvest a crop of hay and the second crop may be gathered f'or seed, as it does not make a seed crop until the second year. When harvesting the crop for seed, a sufficient quantity will shatter so as to reseed the ground without having to sow agaill. This should be remembered, and we would recommend the harvesting of Sweet Clover for seed, as it is a heavy producer of seed. It is not un. usual to harvest from 4 to 6 bushels of seed to the acre yields of as high as 11 bushels have been reported.
This variety grows on all soils and conditions, so no one can go wrong in sowing it. Nothing better for wornout land. clay soils, wet bottom land, or, in fact, any land. No matter whether the poorest soil or the best-wet or dry-it will make the best paying crop.

YELLOW BLOSSOM BIENNIAL.-(Melilotus Officinal.) This variety is very similar to the White Blossom, but it does not grow quite so large and for this reason many prefer it for hay and pasture. If you wish Sweet Clover for fertilizing, the White Blossom is considered superior, but if you wish to grow for hay, we do not hesitate to recommend this variety to you.

YELLOW BLOSSOM ANNUAL.-(Melilotus Indica.) This is a variety of Sweet Clover, growing from 15 to 20 inches high, which is being used by many who wish something for quck results. It comes on earlier and makes a full crop the first season. It is a very valuable plant for the purpose of sowing with grain in the spring, as it will make a splendid growth of humus, restores nitrogen to the soil, and can be plowed under in the early fall, thus being equal or superior to a heavy coat of barnyard ma50 


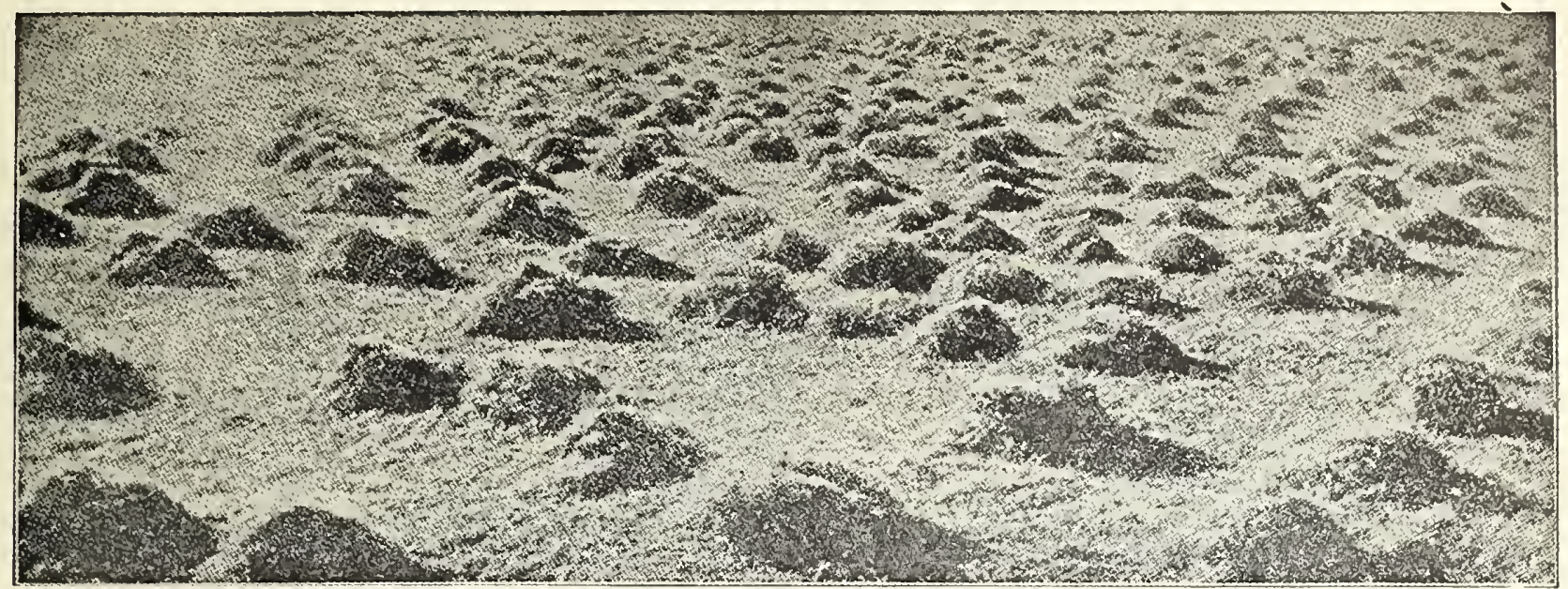

\section{CLOVER Cont.}

preparatory to sowing Alfalfa when they wish to have it follow a grain crop. You sow the seed in the spring and right after harvest the crop is plowed under, making the ground in splendid condition for Alfalfa.

ALSIKE CLOVER.-Known as Swedish Clover. Increasing in popularity very rapidly as its great worth is being recognized. This is a wonderful Clover, adapted to all kinds of soil where grass will grow, but especially adapted to moist, wet soil, where it is subject to overflow; providing the water does not stand on it too long at a time. There are thousands of acres of land scattered over the country that should be in Alsike Clover. Wet land, where not mucl but weeds, wire grass or swamp grass is growing, would produce a wealth of fine grass that is valuable for both pasture and hay.

Alsike Clover is not such a coarse plant as the Mammoth or Common Red Clover; more the nature of White Clover, except that it is much more erect, grows even better than Common Clover. The blossoms are purple-very similar to the blossoms of Alfalfa in size and color. It makes splendid hay for stock of all kinds and is especially fine for horse feed.

This is a splendid year to use Alsike, as it is much cheaper to sow than Common Clover. The seed is about the size of Timothy seed and goes much further. You will save money by using Alsike Clover, and will be delighted with results. Yov should buy AJsike Clover freely this season

WHITE DUTCH CLOVER.-Commonly known as Clover, that makes such good pasture and is so valuable for lawns. It is the hardiest of all clovers, and accommodates itself to all manner of soils. Will endure the extreme heat and dryness of summer better than Blue Grass. Will not tramp out. Keeps soil from washing. It requires less to sow than others, as 5 or 6 pounds per acre is sufficient.

JAPAN CLOVER.-(Lespedeza.) This is particularly suited for waste lands, woodland pastures: grows fairly well on poor soils and spreads rapidly, and when once established usurps wild growths, and will in many cases even subdue broom sedge. It is not, however, a pest, and can be gotten rid of by plowing it up, and is excellent as a fertilizer. Highly recommended for cover crop in orchards and used extensively for this purpose. Japan Clover is particularly valuable for pastures on such soils as described, and where the soil is good yields a f'air quantity of good hay. It is relished by cattle, is nutritious and fattening. To obtain a stand, it is only necessary to scatter the seed broadcast in the spring during Marcl and April at the rate of about 10 pounds per acre. Harrowing the land over before the seed is sown, when it can be done, is, of course better, though this is not imperative.

MEDIUM RED CLOVER.-This is regarded as the most valuable of the Clover family, and is largely used for pasturage and hay. Clover adds greatly to the fertility of the land on which it is grown. It does not exhaust the soil, but enriches it. It makes two crops each year. The first is usually cut when it is in blossom, for hay. The last crop may be harvested for seed, cut for hay, or plowed under to add fertility to the soil. For hay, it is particularly well adapted for sowing with Orchard and Tall Meadow Grass, as it ripens at the same time, and sowing these three grasses together will give larger yields and better quality hay than sowing either alone. It is also largely sown with other grasses, both for hay and pasturage. When sown by itself', sow 8 to 10 pounds to the acre, either in the spring or fall.

MAMMOTH RED CLOVER.-This grows much taller than Medium Red, with larger, leafier stalks. It makes good hay, if cut soon enough, although it has a coarser stem than the Medium Red. Being a rank grower, it is very valuable for fertilizing purposes. The foliage and flower are darker than the Medium Red, and it ripens later and makes only one crop. Especially valuable on light, sandy soil.

\section{SOY OR SOJA BEAN}

Write for Prices and Samples.

Soy Beans may be utilized either as a soiling crop, pasture crop, hay crop, or grown for seed. As a soiling crop for cows, no crop surpasses them for producing a high yield of milk. Hogs turned into a patch of Soy Beans as the Beans are commencing to form will make a phenomenal growth. The Soy Beans will produce under favorable conditions 12 to 13 tons of fresh fodder per acre, containing large amounts of crude protein and fat, which makes an excellent forage to mix with corn fodder or other forage plant high in carbohydrate, but low in protein.

You should consider its value as a grain. as no other grain crop causes as high a per cent of protein and fat, analyzing richer than oil meal, nearly equal to cotton seed meal, and far more palatable and digestable than either.

Its value as a forage crop shows by chemical analysis test that it compares very favorably with Alfalfa.

Culture.-Soy Beans do best on a medium soil, but will make a splendid growth on poor soil. Ground should be well prepared and planted about the same time as Corn. If crop is desired for hay, sow broadcast ol drill about 1 bushel to the acre, and to sow

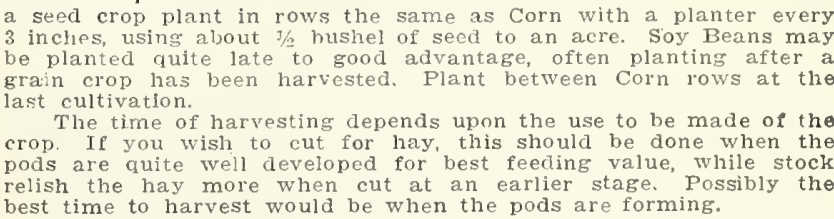

MAMMOTH YELLOW SOJAS.-Largest growing and most popular of Soja Beans for forage purposes. A little later in maturity than other kinds, but makes larger yields, both of forage and seed. Especially valuable for this section and further south. This Mammoth Yellow is the most desirable variety to plant.

MEDIUM EARLY YELLOW.-This variety is popular for growing throughont the Central States, as it matures earlier than the Manmoth Yellow. It does not produce as much forage, but it produces a heavy crop of Beans, which 


\section{COW PEAS}

Write for Prices and Samples.

EVERYBODY'S CLOVER-FOOD FOR MAN AND BEAST. BLACKEYES.-Early, quick maturing bunch variety that fruits abundantly on black clay soils or sandy soils alike. Especially desirable for table use.

NEW ERA, WILD GOOSE, ETC.-Early, quick maturing sorts, having bluish speckled Beans. Several different kinds are sold under these naines, but all are popular.

WHIP-POOR-WILL. - A well-known variety, with brownish speckled seed, noted for its vigor and usefulness as a seed, hay crop, or soil-renovator. Most popular of all Cow Peas.

\section{MILLET}

Write for Prices and Samples.

Millet is an important and nutritious hay and forage crop-splendid for dairy cows, young stock and sheep, and yields heavily. It is easily cured, and its rapid growth makes it a splendid "catch" crop. Sow broadcast at the rate of 1 bushel to the acre. It matures from six to eight weeks after seeding: can be planted from April until August, but not too early. Cut while in bloom, before the seed hardens in the head. Two crops can be grown on the same land.

GERMAN MILLET OR GOLDEN MILLET. True Southern-grown seed. In the North Millet is sown almost altogether for hay and for that purpose Southern-grown seed is much the best. It grows taller than does that from Northern seed and that means more hay. It is finer than that from Northern seed and that means better liay. Millet seed produced in the North, even from Southern seed, becomes what we call Common Millet. Not only does the plant change in character, becoming coarser and much more dwarf, but the seed itself shows a change and is readily distinguished by those experienced in handling it. Golden Millet is very sweet and palatable and when fed to dairy cows produces a large amount of milk. On good rich soil it grows 4 to 5 feet high. It is very tender if cut at the right stage, which is when it is in full bloom. About $3 / 4$ of a bushel of seed is sown to the acre. A good yield is 3 to 5 tons of hay to the acre.

COMMON MILLET.-This is similar to the Liberty Millet, except that the heads are smaller and the seeds lighter colored, and it is earlier.

HOG MILLET.-Grows from 3 to 6 feet tall; produces large heads and larger seeds than any other Millet. Seeds contain a high percentage of oil and have a higher feeding value per pound than our common Corn. This plant al ways produces a heavy head of seed. The seeds furnish the best of all foods for poultry. It has produced as high as 75 bushels of seed per acre. One great feature of this Millet is that the seed ripens before the straw, so that it may be cut and bound as wheat or oats. Lhreshed, and a nice green crop of hay put up. while the seed may be housed and fed separately as grain. This plant is an annual, and, like other Millets, must be planted each season. By beginning to sow with early corn-planting and keeping up sowing the first of every month till September 1 we can have fine green foliage for stock all summer.

\section{RED TOP OR HERD GRASS}

\section{Write for Prices and Samples.}

A valuable grass for moist, rich soils, where it thrives very luxuriantly. It is a good variety to sow with Timothy and Clover for meadow or pasture and is more permanent than either of the two. It should be fed close, as, if it is allowed to grow up to seed, the cattle dislike it. On good soil it grows about 2 feet high; on poor, gravelly land about half that height. It has been grown success fully even on alkali land, where other grasses failed. Red Top is commonly known as Herd Grass, and should be more extensively grown, especially in combination with other grasses. Red Top is especially adapted to growing on wet soil, having an impervious subsoil. Because of this climate, it is exceptionally well adapted to land inclined to be wet, or on low, marshy places. It also grows on dry land.

\section{TIMOTHY}

Write for Prices and Samples.

of hay grasses, Timothy is one of the most popular, nutritious and salable. On clay or heavy loams, lowlands or in mountainous districts, provided there is an abundance of moisture, it produces the very best results. On sandy or light loamy ground it does not do so well as Orchard, Tall Meadow Oat, or Red Top Grass. If grazed or cut too close, the stand of Timothy will be seriously injured, besides it does not form as good grazing as many other grasses. The yield of hay is from $1 \frac{1 / 2}{2}$ to 3 tons per acre. Timothy requires good land to make good crops. It does not root as deeply and is not considered as much of an improver as other grasses, consequently should not be sown on land deficient in humus or vegetable matter, nor on soils of a light or sandy nature. Clovers grow well with Timothy and aid it by supplying nitrogen. Timothy. alone, 1 peck (11 pounds) to the acre; or with Clover, 10 pounds Timothy and 6 pounds Clover; a splendid mixture is 8 pounds Timothy, 6 pounds Clover (either Mammoth Clover or Alsike Clover preferred, as they mature at the same time as Timothy), 6 pounds Fancy Red Top, 1/2 bushel Meadow Fescue. Together these will produce most excellent hay, also nutritious and abundant pasture in good loamy clay or low-ground soils; 8 pounds Timothy and 6 pounds Clover when sown together.

\section{VETCH, THE SOIL BUILDER}

Write for Prices and Samples.

Vetch will grow where many Clovers will not grow. Especially is this true of alkali soil, where Vetch does well. It succeeds especially well on sandy soils, and will pay large returns on any soil that is well drained. Vetch is not suitable for wheat lands or acid soils, but a crop of Vetch could be grown on almost every farm in any community and prove to be a big-paying proposition.

Vetches are a very hardy crop. Especially is this true of Hairy Vetch, as it withstands the severe winters of Michigan, New York and even the New England States. This factor alone makes it desirable in sections where hay and pasture crops often winter-kill. This crop when sown in the f'all will grow rapidly, the rate depending somewhat on the season and soil conditions. It will remain green and give excellent pasturage after nearly all the plants have been killed by the frost, and it will be the first thing green in the spring. Bear in mind that Vetch is adapted to the whole United States of America.

TIME OF SEEDING.-The time of seeding differs in sections, but there is scarcely a point in our country where fall sowing does not give excellent results.

SPRING VETCH.-A very productive and highly nutritious plant; excellent to cut green for soiling or made into hay; splendid feed for cattle and stock of all kinds. We find an ever increasing demand for Spring Vetch, as more is being used for plowing under. It has the advantage over peas in that it makes a greater growth of vine, while, as the seed is much smaller, a less quantity is required to plant an acre. Furthermore, this plant is adapted to the North much better and is unquestionably superior on this account.

Spring Vetch should be sown only in the spring, as it is not hardy, so as to permit fall sowing, except in the extreme South.

SAND OR WINTER VETCH.-A very valuable forage plant. It is very hardy, is valuable as a winter cover crop to prevent leaching and for forage and fertilizing purposes. It is an annual, but resows itself, and will come up year after year on the same ground. It succeeds well on nearly all soils and thrives surprisingly on poor, light land and will endure extremes of drouth, heat and cold. It improves the soil. It may be sown either in the spring or fall with about half a bushel of rye or oats for support. It grows rapidly, and is particularly valuable in sections where Clover does not thrive. When sown in April or May it can be cut in July, the second growth affording excellent pasture during the summer. The yield of green fodder is from 12 to 20 tons an acre. 


\section{GRASS MIXTURE FOR HAY AND PASTURE}

Write for Prices and Samples.

All authorities agree that for pasture and hay the best results are obtained from the use of grass seeds in species. The reasons are obvious. First, a number of species will insure a much denser growth than the same kind of seeds of one or two species and prove less exhausting to the soil, since they live to a large extent on the same constituents; second, seasons that affect some grasses adversely are favorable to other sorts, so that with a mixture failure is practically impossible, provided the seed is good. Our grass seeds secure the highest germination, and mixtures are based on an appreciation of the requirements of the different soils for which they are intended.

A mixture of grasses produces a better meadow and makes a better permanent pasture than a combination of Timothy and Clover. While Timothy is a splendid grass, and Clover the foundation of all successful farming, neither are permanent nor well adapted to pasturing. Both are affected by drouth and frost, making it necessary to resow every few years. Timothy and clover last but a few years, while a good permanent pasture will last ten or even twenty years.

For every different kind and condition of soil there are a number of grasses especially suitable. Some kinds do bost on high ground, and flourish in dry weather, others on low ground and where there is plenty of moisture. Some varieties are so early in maturing, others so late, that if a mixture of grasses is used there will be no time from early spring until snow covers the ground that one species or another will not be at its best.

Meadows sown with carefully selected Grass-Clover mixtures will occupy the ground more closely and will produce a better quality as well as a larger yield of hay and subsequent fall pasturage than can be secured from fields sown with Timothy and Clover alone.

CLOVER, ALSIKE AND TIMOTHY.-This mixture combines the distinct features of our other two famous mixtures. It contains the same proportion of Timothy and divides the Clovers about equally. In this mixture you secure the fine-stemmed, palatable Alsike, which makes the finest hay, and the Red Clover, which grows a little longer, forming a hay rich in Clover or protein food. The same rate of around 12 pounds to the acre, and we consider it superior in many ways to Timothy alone.

MEADOW MIXTURE.--For both hay and permanent pasture. It affords enormous crops of hay of the finest quality and highest feeding value, and after this has been cut it furnishes continuous and abundant pasturage of the richest and most nutritious character until winter sets in. It will stand for years and may be used either for pasturage exclusively or hay and pasturage, as varying conditions may suggest. It contains Mammoth Ped, Medium Red, Alsike, and White Clover, Alfalfa, Timothy, Kentucky Blue Grass, Meadow Fescue and Perennial Rye Grass. Owing to the deep rooting and spreading character of many of the varieties employed, fields. sown with this mixture will, during periods of drouth, look fresh and green, while other meadows and pastures are dry and burned. We recommend at least 30 pounds to the acre.

\section{ENGLISH BLUE GRASS OR MEADOW FESCUE}

Write for Prices and Samples.

Next to Kentucky or Southwestern Iowa Blue Grass. It is very popular, and its growth is increasing each year. Especially adapted for a permanent pasture. One of the standard English grasses, growing from 2 to 3 feet high, but not in tufts like Orchard Grass. The most nutritious of all grasses.

Meadow Fescue is a very valuable grass to have on your farm. It is rich in feeding value, and does not winterkill very easily. It is adapted to all kinds of soils, excepting those that are too dry, and we urge you to at least try a small acreage of it this year.

\section{ORCHARD GRASS}

Write for Prices and Samples.

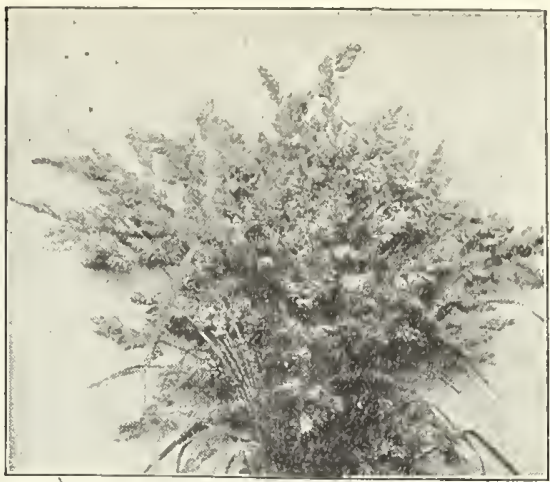

Orchard Grass.

There is much to be said about the desirability of Orchard Grass, and while it does not meet every require ment, it has advantages for many sections and for many fields. No other grass will give equal results. The demand for Orchard Grass the past few years has been gradually increasing, as the farm journals and experimental stations have been advertising the use of it and explaining its virtues. It is an exceptionally valuable grass for pasture or hay land and, on account of its earliness, especially valuable for a permanent pasture. It furnishes green grass very early in the spring and until late in the fall. When closely cropped, it grows up very quickly and is ready for grazing in ten or twelve days. When grown for hay, more than one crop can be obtained, in one season. and when only one crop is cut the aftergrowth is very heavy and gives splendid and rich pasture till late in the fall. The roots extending to a great depth, it will stand drouth better than most other grasses and is very hardy. It grows in tufts and is therefore best sown with other grasses. It is well suited for shady places. such as orchards and groves. It grows on all kinds of land, but does best on deep, rich, sandy loam or clay soils. Height, 3 feet. It flowers in June about the same time as Red clover and is often growis with it. It blooms three weeks earlier than Timothy.

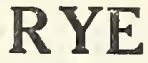

\section{Write for Prices and Samples.}

WINTER RYE.--Experience with drouth and winterkilling during the past two years has led farmers to seek a crop which would be proof against these. Winter Rye is, without doubt, a crop which will endure the most punishment from extremes of heat, cold and drouth of any crop now glown.

Much can be said in favor of Rye as a forage crop. On account of its rapid growth it affords excellent pasture, both fall and spring. It can be pastured very late in the spring and then produces a very good crop of grain. Ask for prices.

\section{RYE AND VETCH}

The advantages of mixing Vetch with the Rye are several. We get more and much better feed, and the fact that the Vetch is one of the best soil builders known means that we are increasing the soil fertility of the land.

During the past season something over one thousand acres of Vetch and Rye were sown in the Kaw Valley on potato land. This was simply as a cover, or green manure crop, being turned under about November first as a fertilizer. In this case Spring Vetch was sown, and with the best success. This coming year we are expecting this system to be followed in other potato growing districts such as the American Bottoms near St. Louis, and the Scotts Bluff country in Nebraska.

Vetch and Rye is coming into its own, proving one of the best cover crops ever grown. Not only on potato land, but on any land which the farmer wishes to build up, this combination will be found one of the best. 


\section{SUDAN GRASS}

\section{Write for Prices and Samples.}

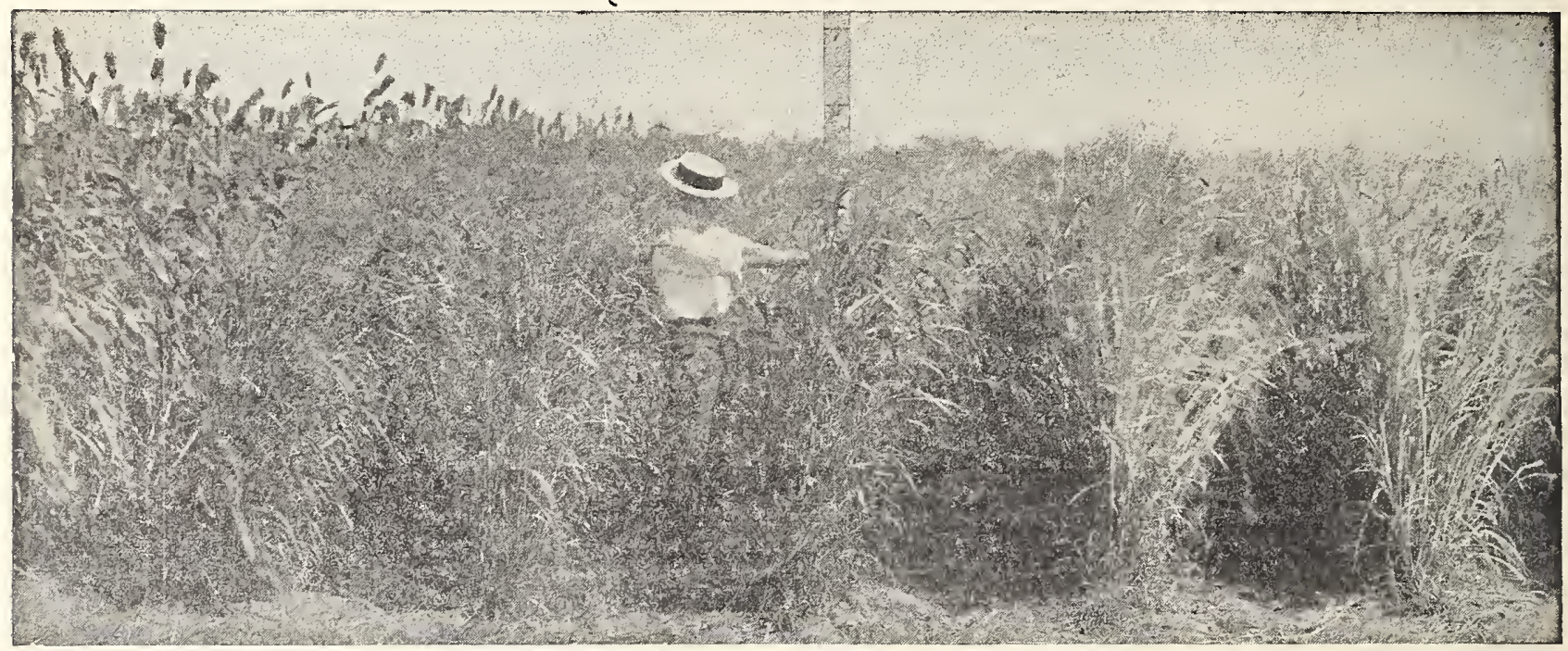

A sweet, heavy-yielding grass; absolutely drouth-proof; grows successfully everywhere in the west; stock of all kinds eat it greedily; yields more tonnage than any other forage crop per acre.

Every stockman and experiment farm that has tested this grass states that it is fine hay and stock eat it in preference to Alfalfa. It analyzes over 9 per cent protein.

GROWING THE CROP.- It may be grown either The seed should not be sown until the ground is warmdrilled, in cultivated rows, or broadcasted. If planted in cultivated rows, the rows should be as close as possible, and yet permit of easy cultivation. In 24 to 30 -inch rows, 2 to 3 pounds of seed per acre is ample; and, under conditions of very low rainfall, this method is recommended. Under humid conditions, 18-inch rows are preferable, ana 5 pounds of seed per acre are sufficient. For drilling or broadcasting, 15 pounds of seed per acre should be used.

that is, about the time for planting corn. The young plants will withstand slight frosts without injury.

HARVESTING THE CROP.-The hay should be cut as soon as the grass is fully headed, and early cutting is especially advisable where two or more cuttings per season are expected. The grass can be cut with a mower, but more conveniently with a binder, especially in dry regions, as the hay cures very readily in bundles.

\section{OATS}

Write for Prices and Samples.

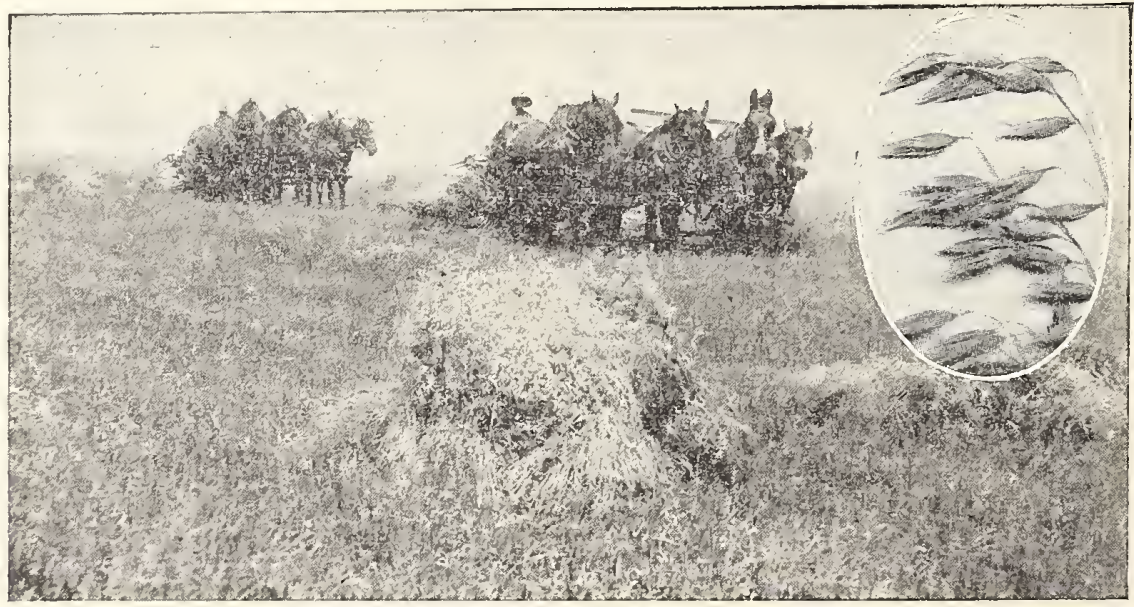

TEXAS RED RUST.PROOF.

DESCRIPTION.-The Texas Red Rust-Proof Oats are not a handsome Oats to look at, but what they lack in beauty they abundantly make up in certainty of crop and yield. They grow to a medium height, $3 \frac{1}{2}$ to 4 feet tall, having a sprangly head well filled with grains, often running 100 to 125 kernels to the head; also a splendid stooler. The grains or kernels are of' a yellowish-red cast, with a husk extending well out over the tip ends, hence do not weigh out quite as heavy per measured bushel as some other varieties, but easily make up this difference in bushels. In brief, we can most heartily recommend these Oats and their adaptability to any place where Oats are grown, and especially recommend them to our Southern friends and customers.

We have made a leader of our Rust-Proof Oats for several years and have found it the best all-purpose variety, and it has given the very best of satisfaction. Many customers report extravagant yields and everyone speaks in the highest terms of it. We want to urge you to get started growing our Rust-Proof Oats.

This variety is a wonderful yielder. Machine measures from a crop have shown a yield of 128 bushels per acre. It is absolutely rust-proof. The grade of Oats is the highest, plump, heavy berries, with lots of meat, which makes fine oat meal. 


\title{
CANE AND SORGHUMS
}

\author{
Wrile for Prices and Samples.
}

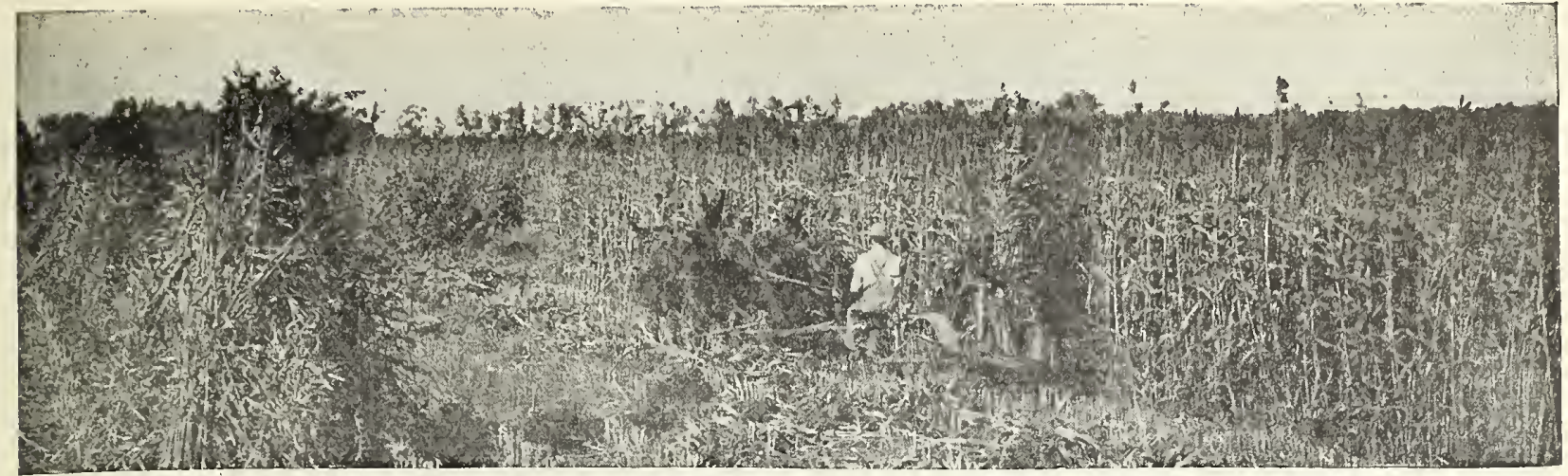

For soiling or green feeding, Cane is of very high value, especially during the summer and autumn, when the pastures are dry and it is hard to find sufficient fodder to keep the animals in a thrifty condition. It is one of the best foods that can be used to feed growing animals and also the dairy cattle, on account of the flow of excellent milk which it will produce. An acre of Cane often produces as much as 40 tons of green fodder, but the a verage yield is probably only 20 tons.

TEXAS SEED RIBBON CANE.-For syrup, forage and ensilage. One of the best varieties that you can plant for syrup purposes. Every planter who has tried this wonderiul raricty is more than well pleased; and for the increasing demand of ensilage crops you cannot find a Sorghun that will give you more universal satisfaction. Tlie suncriority of this Cane over other Sorghums is so great that when once grown it always will be planted, whether for forage. ensilage or syrup. The stalks grow from 12 to 15 feet high, being ready to cut and grind the latter part of August, while common Cane is not usually ready to cut bere October. Cut with the foliage and run turough the nill, it makes the finest kind of ensilage for

\section{FETERITA}

Write for Prices and Samples.

Feterita belongs to the same class as Kaffir Corn and Milo Maize, but is considerably earlier than either one, and is said to stand drouth better and makes a larger, softer grain. In manner of growth, it is about half way between Kaffir Corn and Milo Maize, but the heads stand perfectly straight and erect, and the grains are very large, pure white, and comparatively soft. It can be fed without grinding.

\section{MILO MAIZE}

Wrile for Prices and Samples.

A non-saccharine Sorghum of high value; cultivated like Corn. It is a vigorous grower, of deep green color, attaining a height of 8 or 10 feet. Some stalks develop 20 heads. The seed is fed to horses, cattle, chickens, etc. It will mature its main head in 100 days, and will continue growing until frost. Plant 4 to 5 pounds por acre. Similar to Kaffir Coln, but grows larger heads and produces a slightly larger grain. Cultivation is same as for Kaffir Corn. It will pay you to try it.

\section{SUNFLOWER}

Write for Prices and Samples.

The Sunflower during the past two or three years has proven to be an excellent crop for ensilage. Poduces an prormous tonnage of from 20 to 30 tons per acre. Fed to enormous ton it is found to be satisfactory in every way. The cows were just as anxious for it and produced as The seed is also valuable as a poultry and hog feed. Should be sown in rows far enough apart to admit of cultivation. Two to 3 pounds are sown per acre. all kinds of stock. The yield of molasses is from 250 to 400 gallons per acre. It will grow anywhere that Sorghum will grow. In planting, prepare the ground and cultivate the same as for Sorghum. Plant in rows $3 \frac{1}{2}$ feet apart: 6 to 8 pounds will plant an acre if planted in drills. The Seeded Ribbon Cane is sweeter than the Orange, the syrup lighter colored.

EARLY AMBER.-This is the quickest maturing variety of the sweet Sorghums, and was formerly the variety most generally grown for syrup and for forage. It is still preferred in the Northern States because of its earliness, but in the Southwest Red Top has proven to be a heavier producer.

ORANGE.-This is also an old and popular variety for both syrup and forage. Usually matures ten to fourteen days later than Amber.

RED TOP, OR SUMAC.-Of the many varieties of sweet Sorghums, Red Top or Sumac is the one most generally grown. It is vigorous and drouth resistant, and makes larger yields than any other sweet Sorghum. The seeds are red to orange yellow.

\section{RAPE}

\section{Write for Prices and Samples.}

DWARF ESSEX RAPE is an annual, bearing a close resemblance in leaf' and stalk to the Rutabaga, but both leaves and stalk are more numerous in the Rape plant and of a taller habit of growth. It is a pasture plant, which may be eaten off by any kind of livestock, but it is preeminently fitted to furnish pasture for sheep, cattle and swine. A good crop will furnish at least 12 tons of green food to an acre. Rape thrives best on a good soil, rich in vegetable matter. Slough lands are excellent.

When Rape is sown broadcast, 5 pounds of seed an acre will suffice; when sown in rows, say 30 inches apart and cultivated, from 1 to 2 pounds an acre will be enough.

\section{BUCKWHEAT}

\section{Write for Prices and Samples.}

Buckwheat should be sown about the middle of June at the rate of from $1 / 2$ to $3 / 4$-bushel per acre You will avoid the danger of its spoiling by threshing as soon as diy.

JAPANESE.-This is a very popular variety of Buckwheat. The plant is of stronger growth than common Buckwhe:at and resists drouth and blight much better. The grains are a rich dark brown, having a thin hull and larger grain than Silver Hull. It ripens a week earlfer than other varieties, and is perhaps the best for light or sandy soils and for the dry climate of the West.

SILVER HULL.-This is a thin-shelled Buckwheat of a silver gray color. It has a very solid, medium-sized grain. It stays in bloom longer than tle other varieries, thus producing a larger crop. The flour made from silver Hull is light in color. This variety is most excellent for 


\section{KAFFIR CORN}

Write for Prices and Samples.

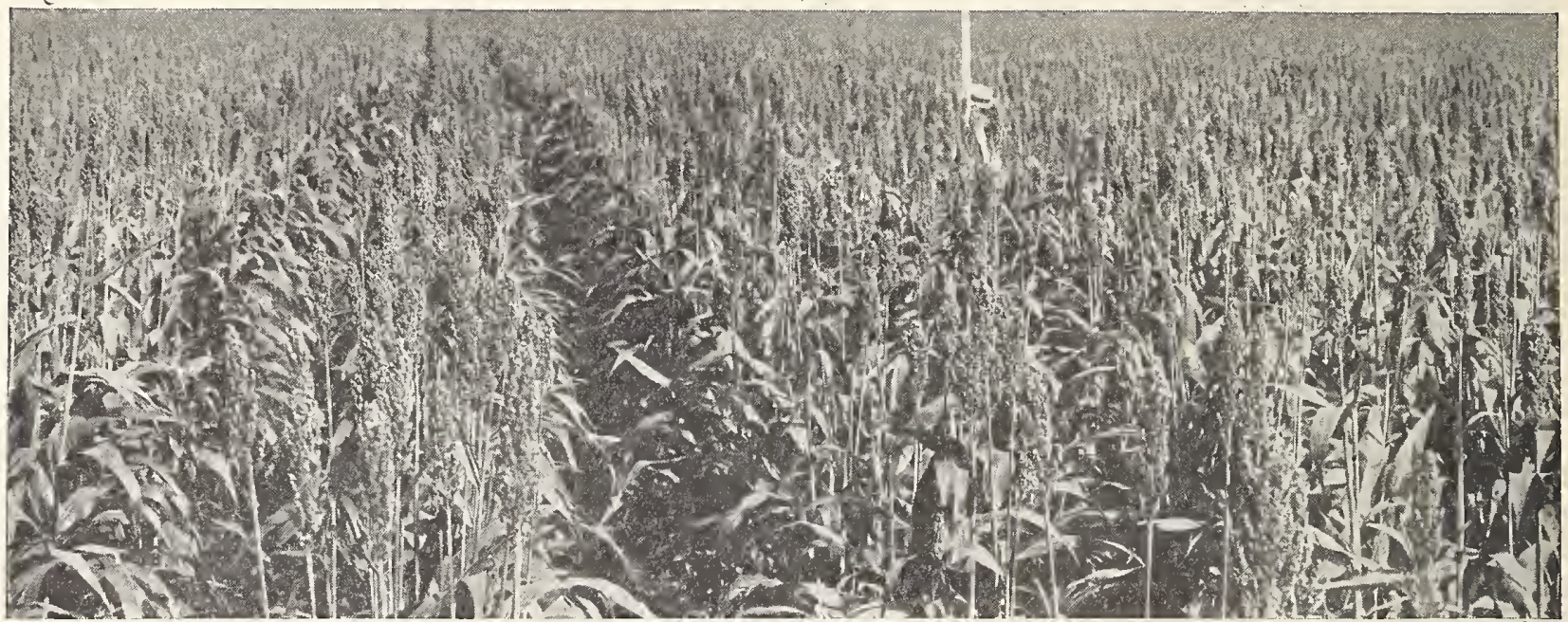

Kaffir Corn is the principal grain crop in many sections of the Southwest on account of not being affected by drouth. It is being more generally used, and we take pleasure in recommending it, not only as a grain, but as a hay crop. Kaffir Corn makes a great yield of the finest kind of feed, when sown broadcast and cut for hay. It has advantages over Cane, as the hay can be cured the same as Millet and stacked, making higher quality of feed. We have a large stock of extra fine seed, testing high for germination, and can supply you with seed that will make the best yield. Valuable both for fodder and grain. Always yields an immense crop of seed, even on the poorest of soils and in driest seasons. Especially adapted where summers are hot and dry.

Sow broadcast and handle like Cane, putting on from 75 to 100 pounds per acre, or drill with Corn planter, putting on about 10 pounds per acre, then cutting with a Corn harvester and threshing like grain. Sonie foed it to stock, heads and all, while others cut the heads off and thresh them. Any way it is treated it makes a valuable feed.

STANDARD KAFFIR CORN.-Sow in rows $2 \frac{1}{2}$ to $31 / 2$ feet apart and cultivate the same as Corn. Five to 10 pounds will seed an acre in rows, or $1 / 2$ bushel broadcast.

\section{DWARF KAFFIR CORN}

An especially fine fodder plant. It grows from $3 \frac{1}{2}$ to 5 feet in height-depending on the quality and condition of the soil and also on the weather conditions. The heads are larger and more shapely than those of Kaffir Corn. Stalks keep green, not getting hard like other Sorghums, and are juicy and brittle. Dwarf lKafẗir Corn makes fine fodder, either green or dried, and is relished by horses and cattle. Dwarf Kaffir Corn is the result of careful selection and produces a plant of uniform dwarf growth. It makes a crop in less time than the usual type of Kaffir Corn.

\section{BROOM CORN}

\section{$W$ rite for Prices and Samples.}

EVERGREEN OR STANDARD.-Is a favorite in Kansas, Nebraska and Missouri. It grows to be a good length, and if cut at the proper time has a good color, but if allowed to stand will redden at tip as seed ripens. Ask for prices.

DWARF EVERGREEN.-This is a very popular variety on account of its not being so liable to blow down and lodge as the taller varieties. Heads are vory bushy,

and it makes a fine yield. Ask for prices.

OKLAHOMA DWARF BROOM CORN.-This is the variety most generally grown in the Southwest. Very early, strong-growing, and productive, but only about 5 feet high, making it easy to handle the long and wellfibered brush. Seed is from progressive Broom Corn growers who know the market requirements and improve their seed by selecting each year. Ask for prices.

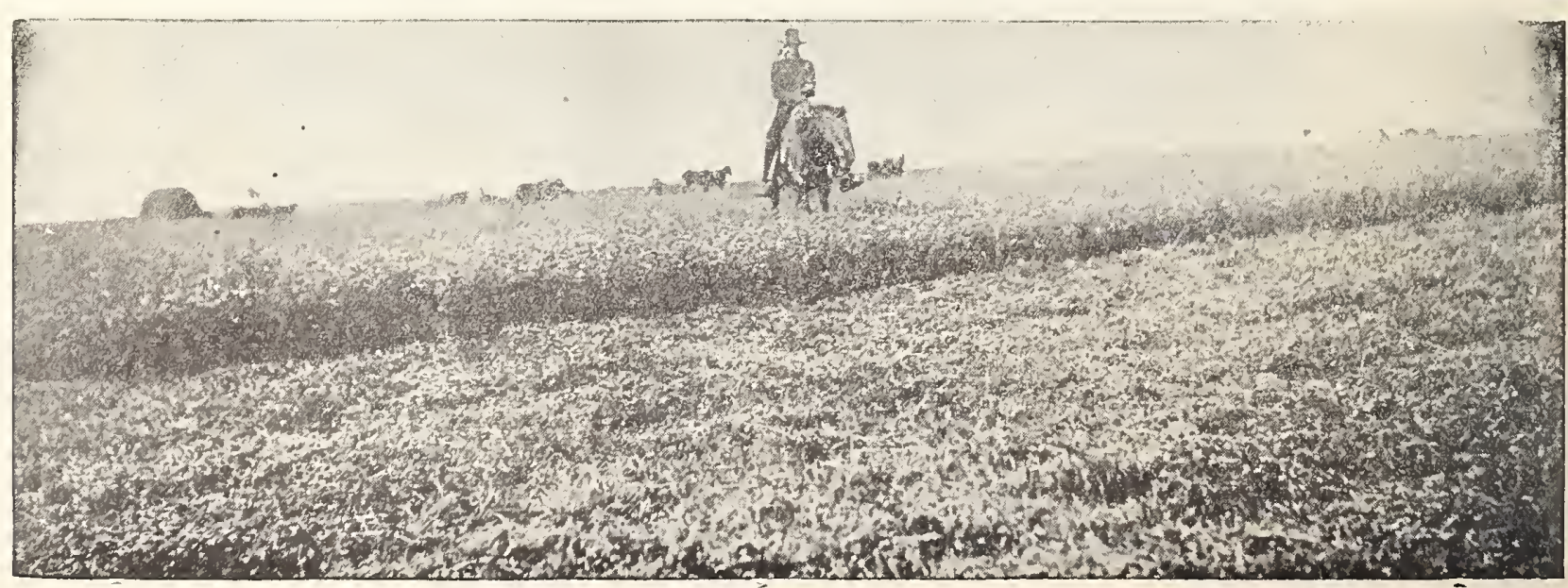




\section{FRUIT TREES}

Fruit-growing as an industry has rapidly advanced in recent years; farmers are getting large returns from this source. The man with a small lot and the suburban acreage-owner are also interested as they find it fascinating as well as profitable. Our trees are straight, of moderate size, are guaranteed true to name, and, if given reasonably good care, will thrive.

\section{APPLES.}

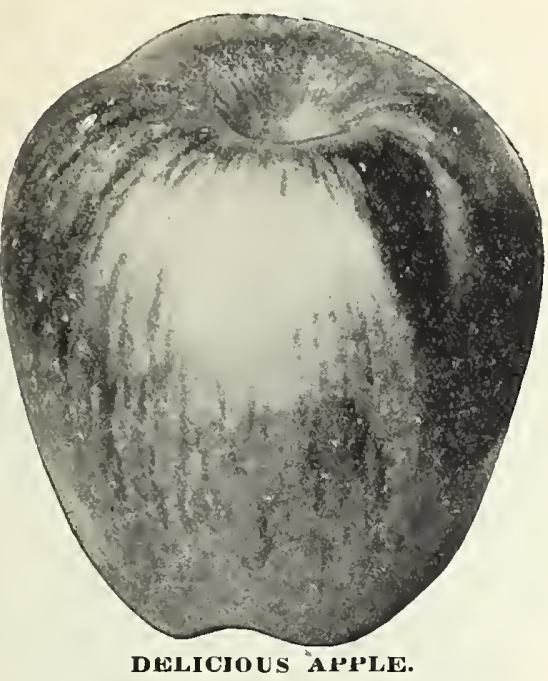

4 to 5 Ft., Each, $\$ 0.75 ; 10$ for $\$ 6.50$. 5 to 7 Ft., Ench, $\$ 1.25 ; 10$ for $\$ 11.00$

We offer the very largest to be had and guarantee them to be entirely free from scale and other diseases.

EARLY STRAWBERRY. Very delicious early eating apple. BALDWIN. Large, bright red, rich, juicy. Winter

BELLFLO WER. Yellow, crisp, large and juicy. November. DELICIOUS. Large, unevenly shaped. Winter.

DUCHESS OF OLDENBURG. Medium. Striped red. Subacid. Fall.

EARLY HaRVEST. Small. Straw color. Fine acid. July. FALL PIPPIN. Large. Yellowish green. Delicious. October.

GRIMIE, GOLDEN PIPPIN. Medium. Sub-acid. November. JONATHAN. One of our favorite fall and early winter varieties. Bright red.

RAMBBo. Summer. Large, yellow; rich and of good flavor. August.

RED ASTRACHAN. Large, crimson, juicy, acid. July.
RHODE ISLAND GREENING. Large, yellow-green. Winter.

SMOKEHOUSE. Medium, red striped. Sub-acid. Winter. STAYMAN'S WINESAP. Medium, bright red. Winter.

YELLOW TRANSPARENT. Pale yellow. Sub-acid. July. YORK IMPERIAI." Medium, white, shaded red. Sub-acid. Winter.

\section{CRAB APPLES.}

5 to 6 Ft., Each, $\$ 1.00$.

TRANSCENDENT. Medium, golden yellow, crimson cheek. September. Strong, stocky trees.

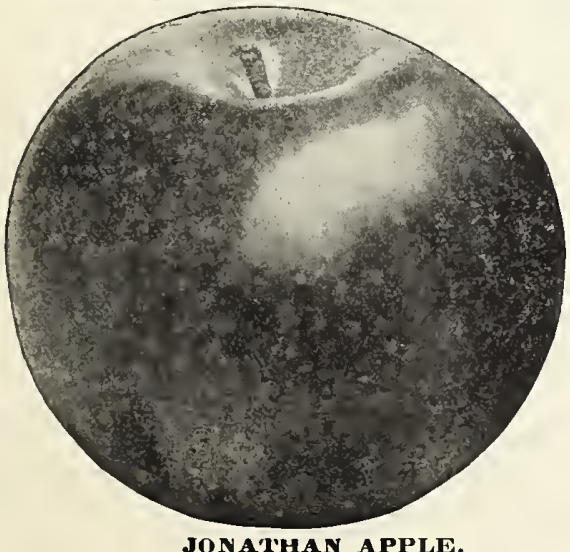

APRICOTS.

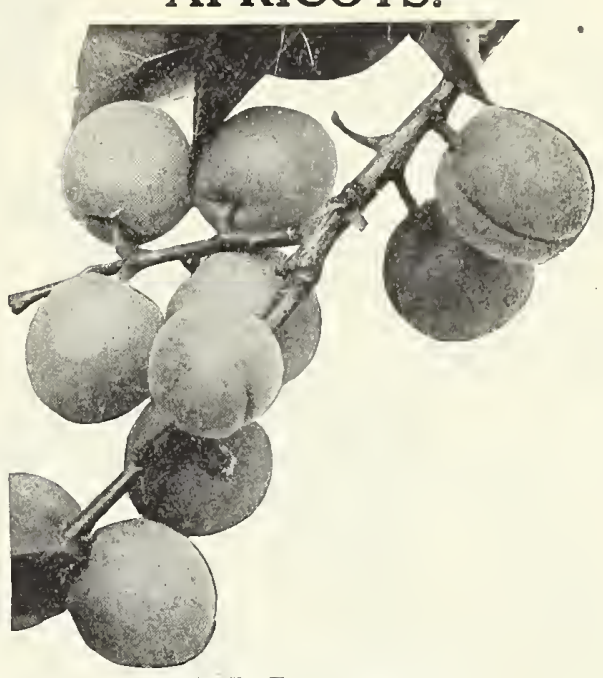

MUORPA IT APRICO'T.

All Varieties, Each, \$1.00. EARLY GOLDEN. Small pale orange. Juicy and sweet.
IOORPARK. Large, deep orange. Rich. August.

\section{PEACHES.}

4 to 5 Ft., Each $\$ 0.75 ; 10$ for $\$ 6.50$.

5 to 7 Ft., Each, $\$ 1.00 ; 10$ for $\$ 8.50$.

Our selection of Peaches is the best hate. They are hardy and all freestone varieties.

CHAMPIoN. Very large, white, red cheek, delicious. Late September.

CRAWFORD EARLY. Medium; yellow. July.

CRA WFORD'S LATE: Very large, yellow, red cheek. Late September.

ELPERTA. Very large, yellow, red cheek, juicy, rich. Middle of August.

IRON IOUNTAIN. Large, pure white, solid, juicy. October. IOUNTAIN ROSE. Medium, white, red cheek, sweet. First TOUNAIN

oLD MIXoN. Large, yellowish white, red cheek, pleasant. Middle of September.

STUMP 'THE WORLD. Very large, creamy white, red cheek, delicious. September.

YELLOW ST. JOHN. Large, yellow, sweet. July.

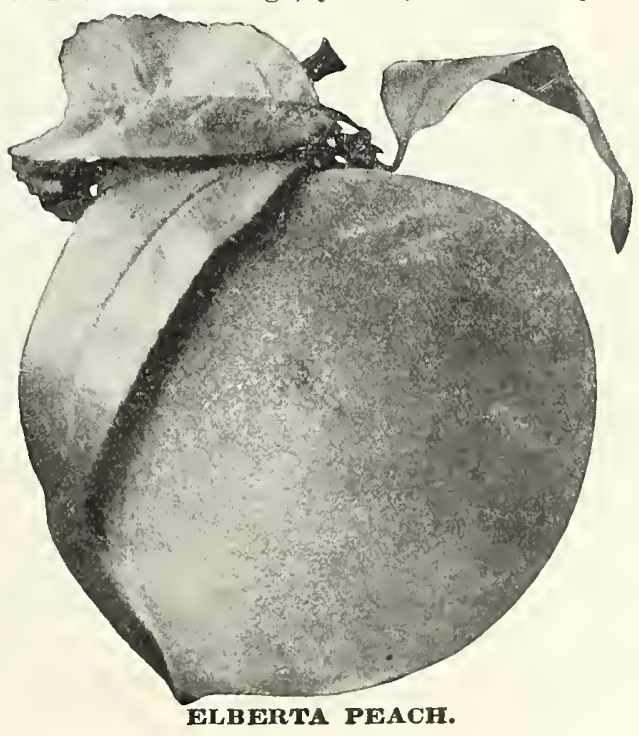




\section{FRUIT TREES---Cont.}

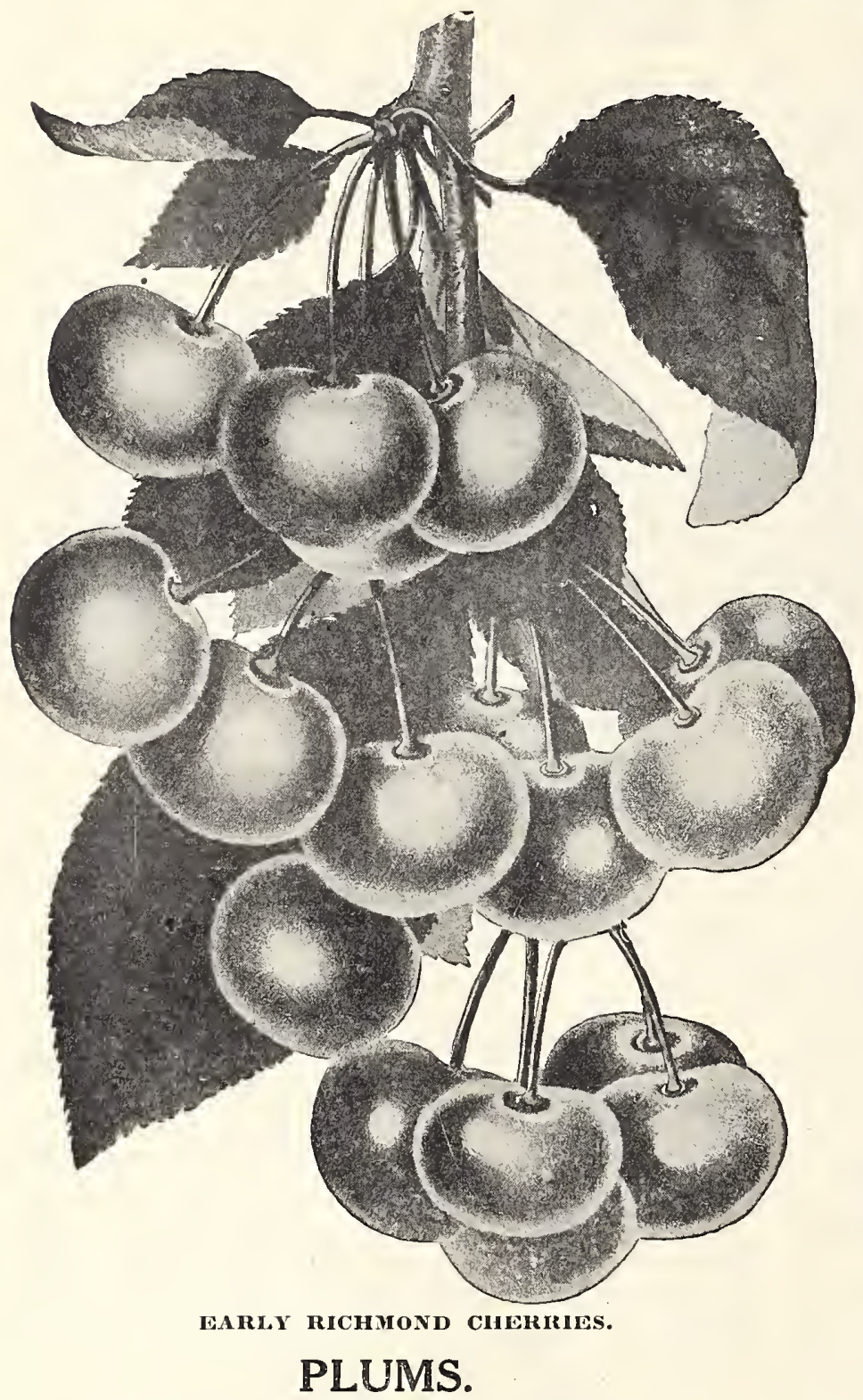

4 to 5 Ft., Each \$1.50; 10 for \$12.50.

5 to 7 Ft., Each \$1.75: 10 for $\$ 15.00$.

ABUNDANCE. Large, cherry-red, sweet. August.

HURBANK. Large, cherry-red, sweet. Last of August.

RED JUNE. Large, purple-red. Very early.

WILD GOOSE. Most prolific. Red.

\section{CHERRIES.}

4 to 5 Ft., Eaclu, $\$ 1.00$; 10 for $\$ 8.50$.

5 to 6 Ft., Each, $\$ 1.25 ; 10$ for $\$ 11.00$.

EARLY RICHMOND. Medium, deep red, rich, acid. Middle of June.

GNGLISH MORELLo. Large, dark red, pleasant acid, Last of July.

MONTMORENCY. Large, bright red, pleasing acid flavor. June.

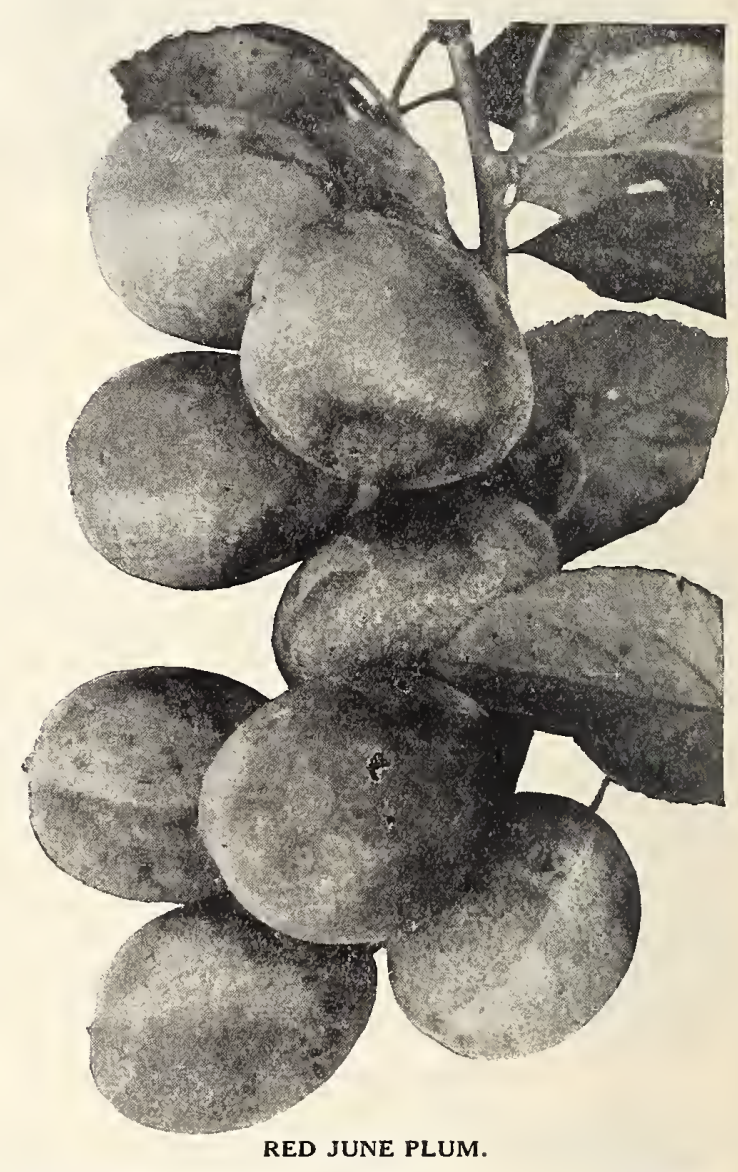

\section{BRYSON AYRES NURSERY STOCK}

I, Every possib!e care is taken to have the stock that leaves this Nursery true to name and description

2. We take extraordinary precautions against insect and fungus attacks, and it is our earnest endeavor to have all our trees and plants entirely free from disease.

3. Ample spreading space has been given each tree or plant in the Nursery; where pruning has been necessary, we have pruned; where spraying has been' "an ounce of prevention," we have sprayed-the whole idea being to make our stock vigorous and of sturdy, persistent growth.

4. The Nursery stock we send out is prepared by the treatment it has received at our hands to do the best that Nature has deemed possible; and frequently it surpasses what we considered to be the limit of possibility. 


\section{FRUIT TREES-Cont.}

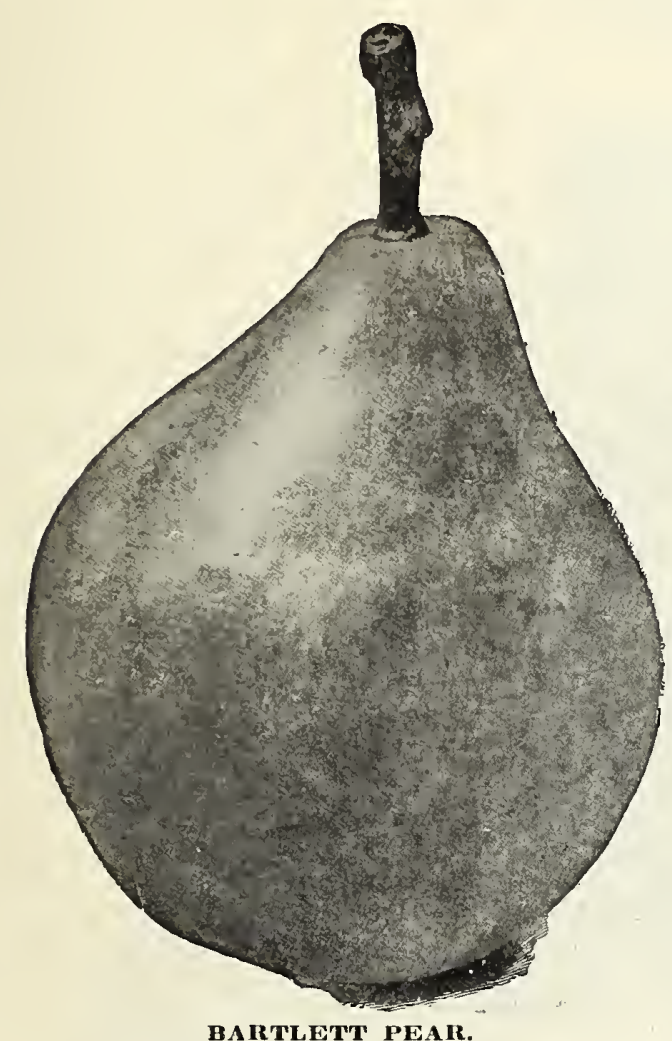

\section{PEARS.}

5 to o Ft., Each, $\$ 1.25 ; 10$ for $\$ 11.00$.

H.IR'ILE'I'. Large, clear yellow, highly aromatic. September.

IUERRE D'CLAIRGLAU, Large, russet, with red cheek. October.

DLCHESS D'ANGOULEME. Large, greenish yellow, juicy. October.

IIOWELL. Medium, pale yellow, mildly sub-acid. September.

IIIEFWER. Large, golden yellow, sweet. October.

1.AWRENCE. Medium, lemon-yellow, sweet. December.

SECIELL. Small, yellowish russet, spicy flavor, August to October.

SIILDON. Medium, greenish yellow, rich and aromatic. October.

V FRMONT IEAUTY. Medium, yellow, red cheek, rich. Octover.

\section{SMALL FRUITS.}

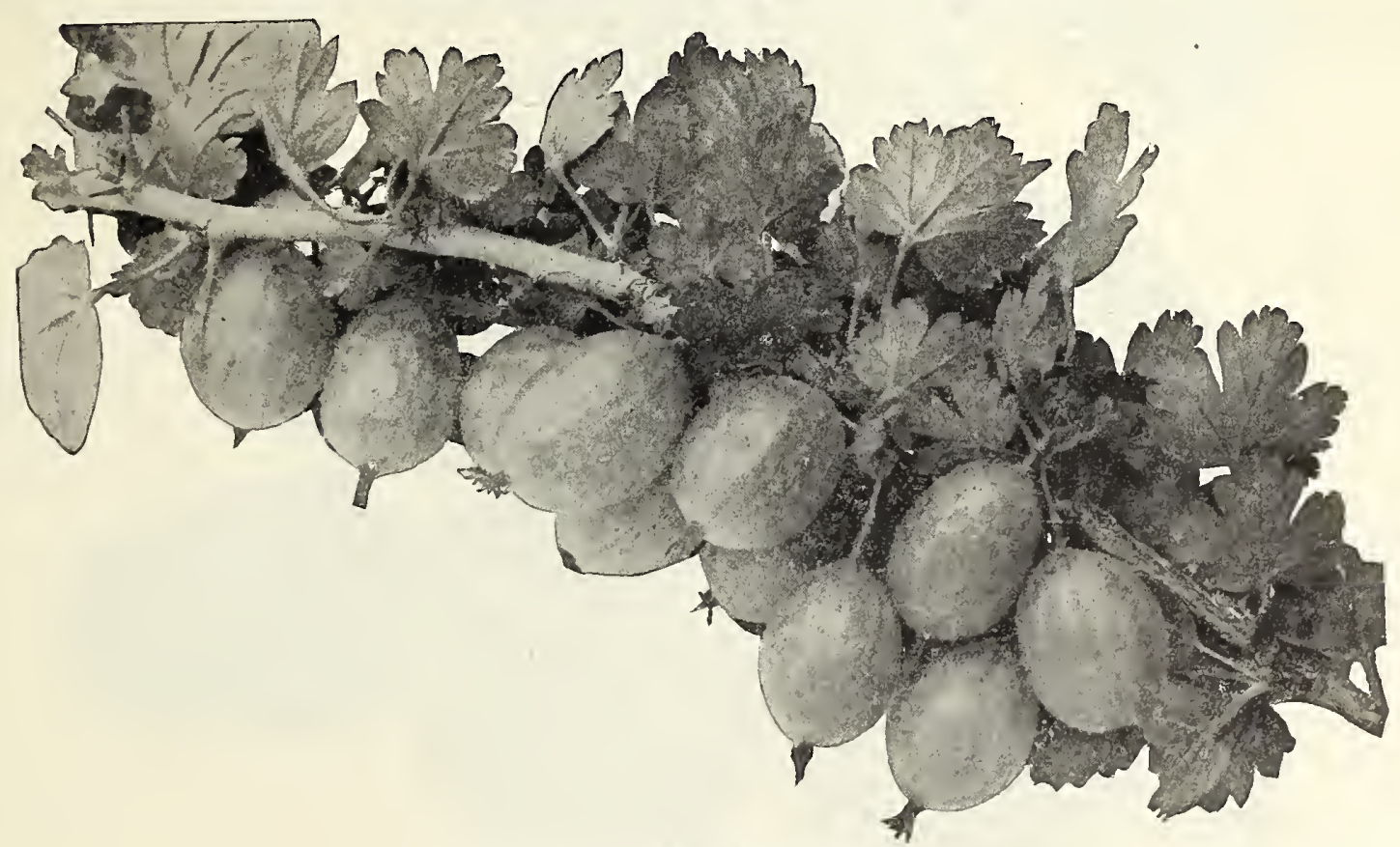

GOOSEBERRIES.

35c Fach; \$3.50 Dozen; Specimen Bushes, Each, 50c.

columBus. Very large and quite sweet. Approaches the old English varieties in size.

HOUGHTON. Medium size fruit and an excellent bearer.

DownING. Extra large and of splendid quality. 


\section{SMALL FRUIT -.-Cont. RASPBERRIES.}

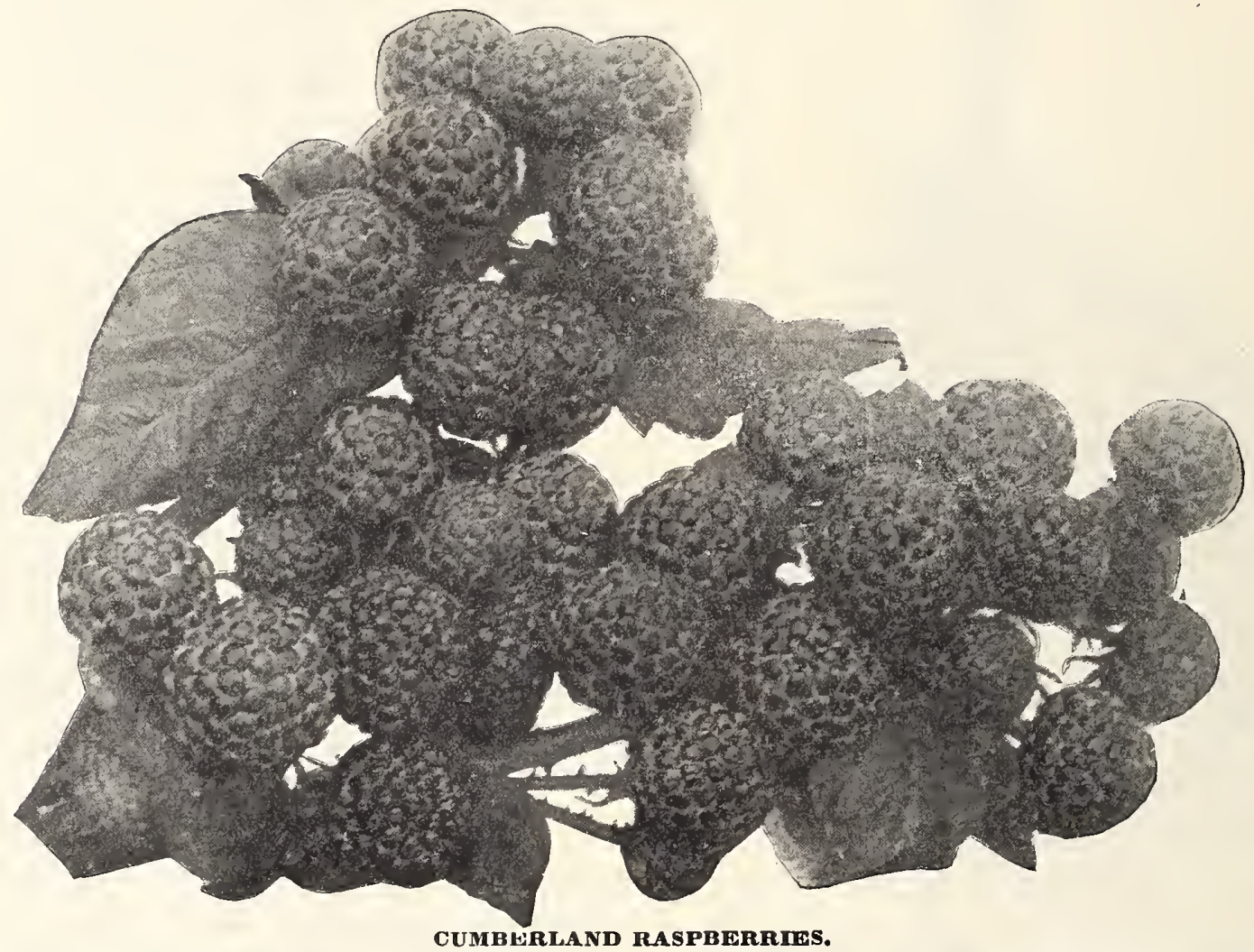

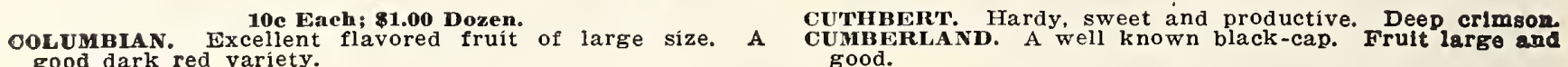
good dark red variety.

\section{BLACKBERRIES.}

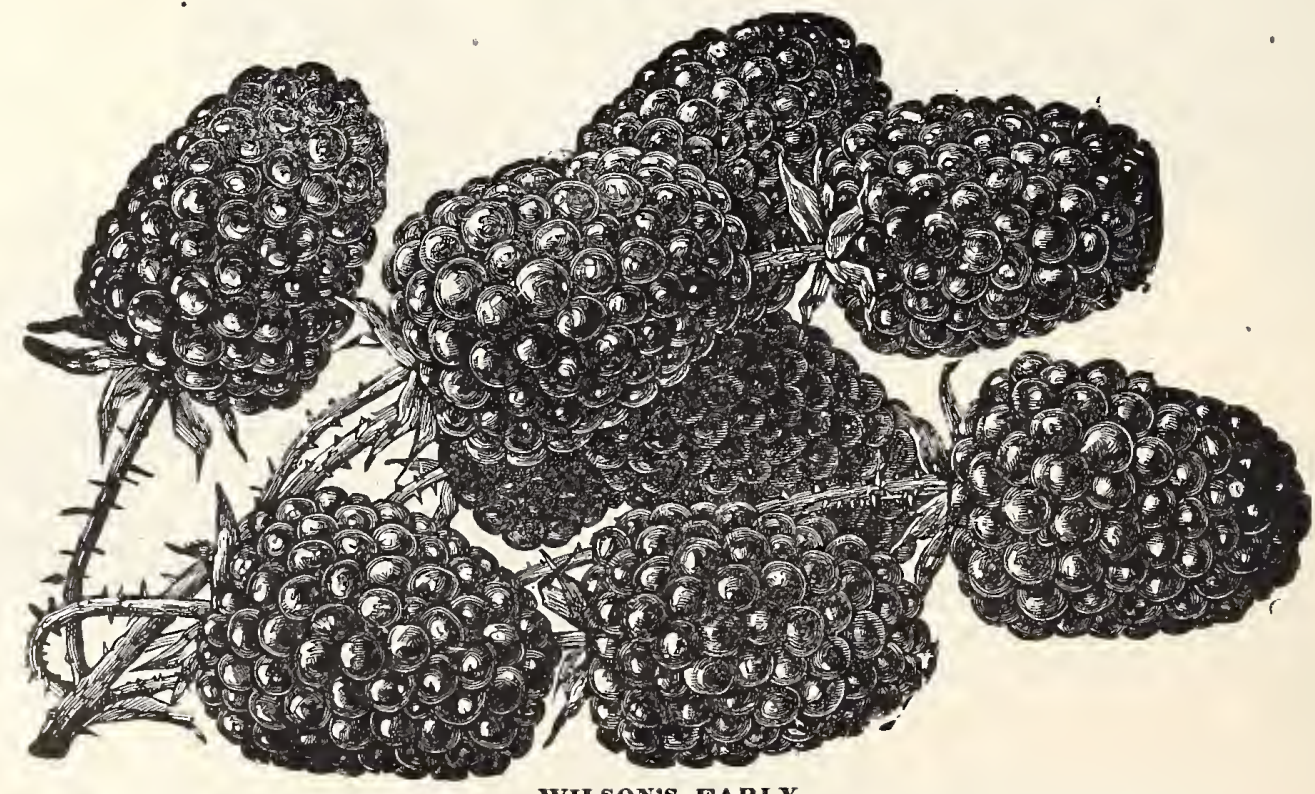

10c Each; \$1.00 Dozen.

WILSON'S FARI, A hardy and productive variety. Fruit EARLY HARVES'T. Extremely early and prolific.
SNIDER. Large berry. Mid-season.

WHITE BLACKBERRY. A decided novelty; dellclous trult. 15e each; $\$ 1.50$ doz. 


\section{SMALL FRUIT -.-Cont. STRAWBERRIES.}

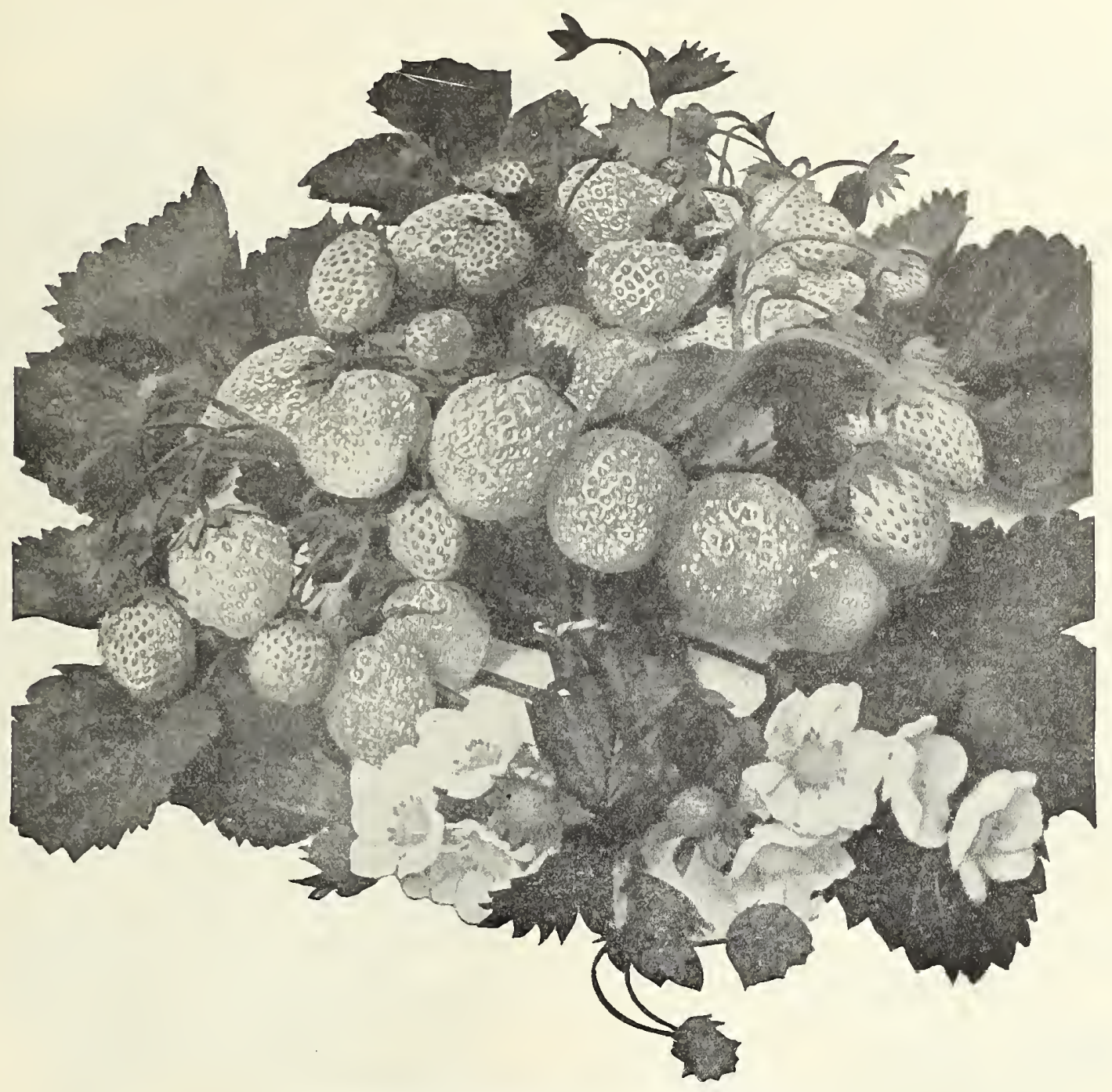

PROGRESSIVE EVERBEARING STRA WBERTIES

\section{EVERBEARING STRAWBERRIES}

The Everbearing Strawberry has "made good" in commercial and home garden planting in widely varying parts of the country.

Plants set out in the spring will bear the same sum. mer and with sufficient rain or artificial watering, will produce a good crop in the fall and continue to bear until heavy frosts come. The second year they produce a heavy crop in the spring, continue to bear throughout the summer if conditions are favorable, and give another heavy crop after the fall rains.

The plants are hardy, vigorous, and productive, and the foliage is unusually healthy. They succeed on all kinds of soil, can be planted on more fertile soil and in low land where frosts threatens the only crop of ordinary, or "standard" varieties.

All Strawberries require moisture and fertility to produce the best berries. This is especially true of the Everbearers, because of their prolific and continuous bearing habits.

After planting in the spring, the blossoms should be pinched off until about the first of July.

The best growing method with Everbearers is the Hill or Stool System. Set the plants 1 to $11 / 2$ feet apart in rows 3 to 4 feet wide. For the home garden. Set in beds 4 to 5 feet wide, with plants a foot apart. Be sure to cut off all runners.

Everybearers should never be planted in the "Matted Row" or "Hedge Row" System.

To insure success, Everbearers must have greater fertility and more moisture than ordinary, or "standard" varieties. In the winter, give them a light dressing of well-rotted manure, which should be worked in by cultivation in the spring.

Owing to our immense acreage devoted to Everbearing Strawberries we offer herewith an unprecedented low price. 40 c per doz.; $\$ 1.50$ per $100 ; \$ 7.50$ per 1,000 .

PROGRESSTE EVIRHEARING. An abundant bearer and seldom without fruit during summer and fall.

SUPEIR EVERBEARING. Every garden should contain some of these. Prolific and very large.

\section{STANDARD VARIETTES.}

40c Per Doz.; \$1.50 Per 100; \$10.00 Per 1,000.

The Strawberry will grow in any good garden soll, where the ground has been thoroughly prepared for famlly use. We list only varieties best suited to-the. soil in Mfrssouri and Middle West.

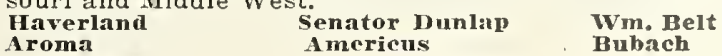

Early ozark Americus Ganda 


\section{SMALL FRUIT -.--Cont.}

\section{GRAPES.}

\begin{abstract}
1-TEAR-OLD VINES.
Each ............... .25

Per dozen ............ $\mathbf{2 . 5 0}$

Per $100 \ldots \ldots \ldots \ldots \ldots .17 .50$

2-veAr-old Vines.

Each $\ldots \ldots \ldots \ldots \ldots \ldots \ldots$. $\mathbf{3 5}$ Per dozen ............ $\mathbf{3 . 5 0}$

Per $100 \ldots \ldots \ldots \ldots \ldots \ldots, \mathbf{2 4 . 0 0}$ 3-YEAR-OLID VINES.

Each ............... $\mathbf{. 5 0}$

Per dozen $\ldots \ldots \ldots \ldots \ldots, \quad 6.00$ Per $100 \ldots \ldots \ldots \ldots \ldots, 40.00$ GRAPE-BIACK.

CAMPRELI'S EARLY. One of the largest fruiting Grapes and extremely satisfactory.

CONCORD. The well-known black Grape. Can always be depended on to fruit heavily. WorDEN. Bunch large and compact. Good large berries and an early fruiting variety. GRAPE-RED AND PURPLE.

CATAWBA. A very nice berry, having an unusually sweet and aromatic flesh.
\end{abstract}

DELAWARE. The well-known small, very swcet red Grape. Comes in small bunches.

SALEM. Berries larger than Catawba, flesh tender, juicy and sweet.

\section{GRAPE-WHITE.}

GREEN MOUNTAIN. A particularly fine white Grape and not well known as yet.

NIAGARA. Th is well-known white Grape needs no description. It should be in every collection.

\section{CURRANTS.}

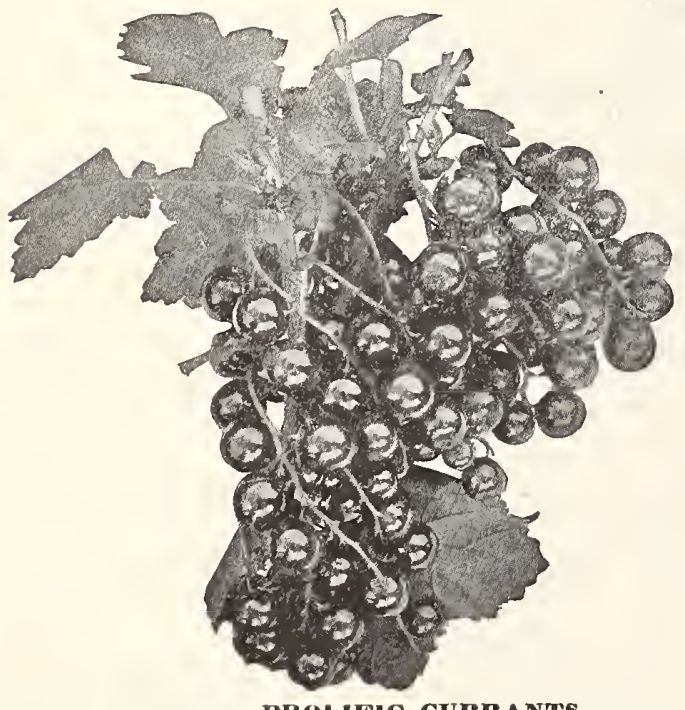

PROLIFIO CURRANTS.

FAY'S PRoLific. This red has been known for years as a dependable variety. Strong, healthy plants. Each, 35c $\$ 3.50$ per doz. Specimen bushes, each, 50c; $\$ 5.00$ per doz.

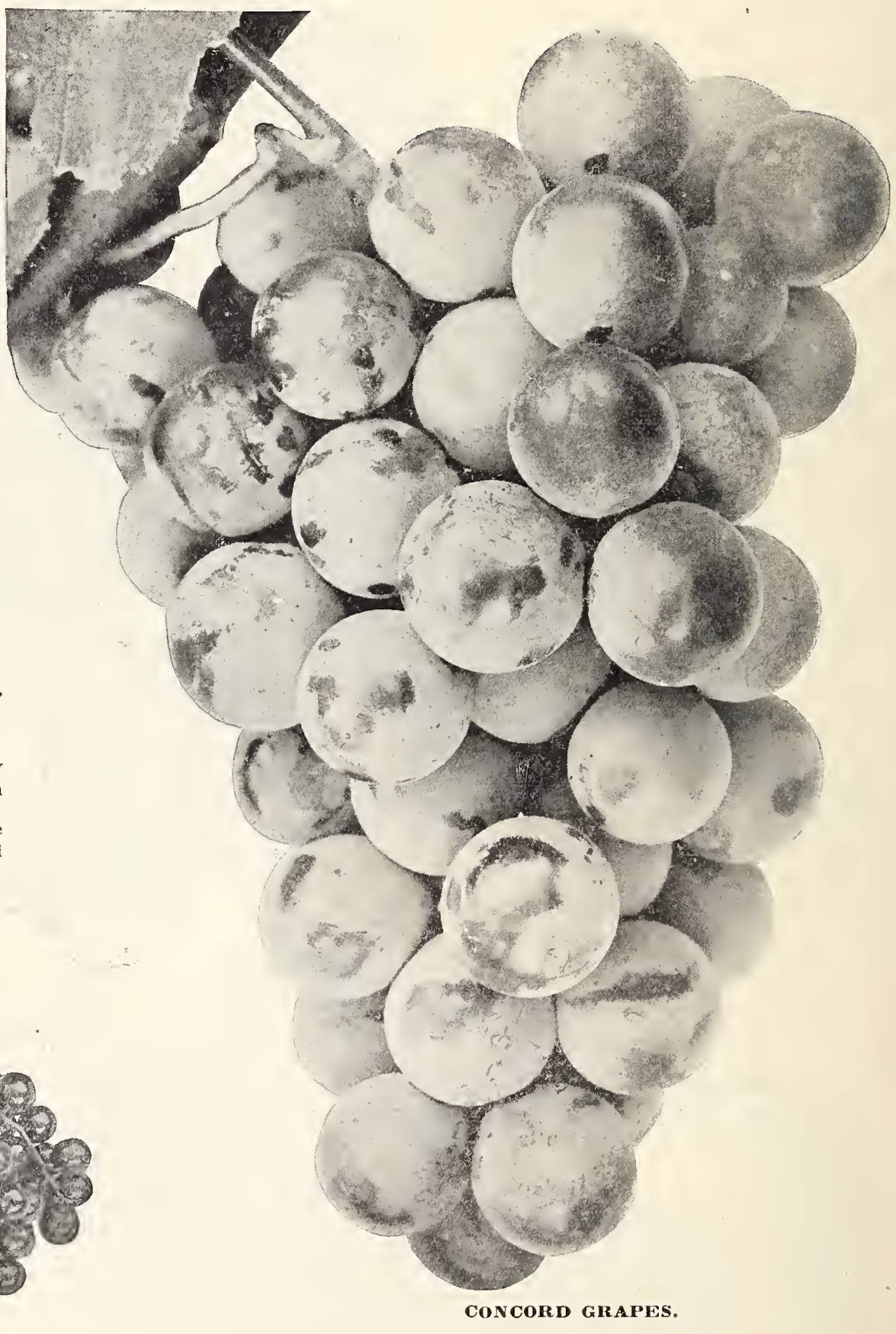

\section{ASPARAGUS.}

CoNover's Colossal., and Barr's Mammoth Palmetto. $\$ 2.00$ per 100 .

\section{RHUBARB.}

Strong roots of fine quality, $\$ 1.00$ per dozen. 


\section{Insecticides, Fungicides, Disinfectants}

We cannot send liquids or poisons through the mails, so hat all Insecticides go by express or freight, not prepaid, unless quoted by parcel post.

\section{PARIS GREEN}

For liquid spraying. Use I pound of Paris Green to 100 200 gallons of water, according to strength desired. It will be found generally strong enough if $1 / 2$ pound is stirred in a barrel (50 gallons) of water, and allowed to stand twenty-four hours before using. In powder form, use 1 pound of Paris Green and 20 to 50 pounds of flour; mix thoroughly, apply evenly, preferably when dew is on plants. Prices on application.

\section{LIME-SULPHUR SOLUTION.}

The best remedy for San Jose scale and other scale insects on trees and shrubs. Use 1 gallon to 20 gallons of water during December and January, but earlier or later dilute 1 gallon to 40 gallons of water. Prices on application.

\section{CALCIUM-ARSENATE.}

(Dry or Paste)

It can be applied, pure or reduced, with any of the dusting machines or guns. From 1 to 30 pounds per acre should be used. In water, for most purposes, use from 1 to $1 \frac{1}{2}$ pounds of the dry or 30 pounds of the paste to 50 gallons.

\section{DEVOE BORDEAUX MIXTURE.}

Dry Powdered Form.

To Control Scales and Blight. For all Fungous Diseases.

The best Fungicide f'or curing or preventing blotch, ot, mildew, blight, leaf curl, scab or other fungous diseases on fruit and plants, if used dry.

For potatoes, dust without reduction, 4 to 5 pounds per acre (according to size of vines).

For fruit trees, dust after reducing 1 pound of Dry Bordeaux with 20 pounds of lime dust.

For spray, to make 4-4-50 mixture, use 8 pounds of Dry Bordeaux Mixture to 50 gallons of water. For 5-5-50 mixture, use 10 pounds to 50 gallons of water.

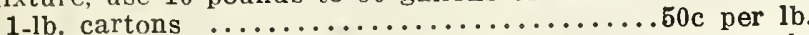

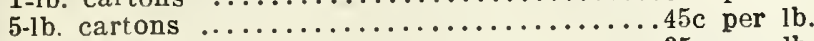

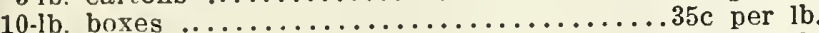

25 -1b. drums . . . . . . . .

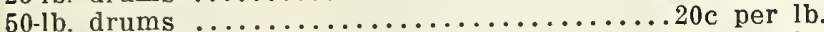

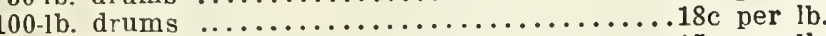

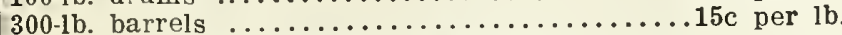

\section{ARSENATE OF LEAD.}

Will be found the best spraying preparation for the destruction of insect pests. Use 3 pounds to 50 gallons of water, or, if preferred, use 50 gallons of Bordeaux mixture instead of water for dilution. Prices on application.

Our stock of this is strictly fresh, from one of the best factories in the country, and will be found the best spraying preparation in the entire list for the destruction of insect pests. Use 3 pounds to 50 gallons of water. or, if preferred, use 50 gallons of Bordeaux mixture instead of water for dilution. Prices on application.

\section{DEVOE "SURE NOXEM."}

Dry Powdered Form. Insecticide to Most Leaf-eating insects.

One of the best vegetable Insecticides in use. Specially recommended for destroying worms and insects.

For cabbage, cauliflower, tomato plants, cucumber vines, melon vines, currant bushes, gooseberry bushes, vegetables and flowers of all kinds attacked by leaf-eating insects.

$1-1 b$. sifter-top cartons ..............20 per lb. 5-lb. packages .........................

10-1b. boxes ......................... per lb.

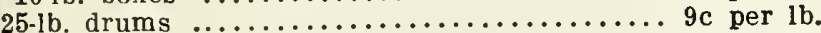

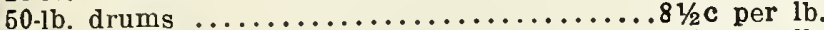
$100-1 b$. drums $\ldots \ldots \ldots \ldots \ldots \ldots \ldots \ldots \ldots \ldots \ldots$. per lb.

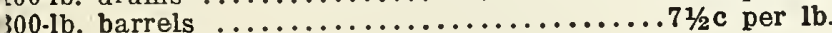

\section{High-Grade Fertilizer.}

\author{
SWIFT'S PLANT FOOD.
}

An odorless concentrated soluble fertilizer for house plants. A package is sufficient for 30 plants for 3 months. 5 lbs., 40c; 10 lbs., 70c.

\section{FRUIT AND ROOT CROP GROWER}

For fruit trees and small fruits, garden truck, tobacco, potatoes, sugar beets. etc. Quick in starting, lasting in effect, giving firm, healthy growth and developing the fruit. Use 250 to 500 pounds per acre. Analysis, 2-10-1/2. 125 lbs., $\$ 3.50$; 250 lbs., $\$ 675 ; 500$ lbs., $\$ 13.00$.

GRAIN GROWER.

For general farm use, but especially adapted for the growing of all cereals. Use at the rate of 250 to 500 pounds per acre. Analysis, 2-8. 125 lbs., \$3.60; 250 lbs., $\$ 6.75$.

\section{CORN GROWER.}

Contains a large percentage of phosphoric acld and potash, the most essential elements in the production of a maximum corn crop. Use 250 to 500 pounds per acre; lialf broadcast, balance in hills or drills, mixing thoroughly with the soil before planting. Analysis, 1-12-1. 125 lbs., $\$ 3.45 ; 250$ lbs., $\$ 6.50 ; 500$ lbs., $\$ 12.50$.

\section{BONE MEAL.}

Highest Grade.-It is ground fine and is an excellent top dressing for lawns, grass lands, farm and fleld crops, also for mixing with potting soil. 100 lbs., $\$ 3.00$.

\section{AMMONIA OR NITROGEN.}

Tends to promote leaf or foliage growth. You will find it in various combinations. In the form of salts or nitrates, is readily available. By the application of Ammonia on land that is low in humus, the general foliage and root growth is stimulated and the amount of vegetable matter in the soil is multiplied many fold. Ten per cent, $\$ 3.25$ per $100 \mathrm{Ibs}$.

\section{PHOSPHORIC ACID.}

Tends to ripen the plant earlier, bring out full solld A moderate application of Phosphoric Acid, in hastening kernels in grain and give color to fruits and vegetables. maturity, will get your fruit and vegetable crops on the market ten days or two weeks earlier than if not fer. tilized. Twenty-six per cent, $\$ 3.00$ per 100 lbs.

\section{POTASH.}

For root affections of grain and forage crops and scab. etc., of potatoes and other truck it is unequaled; no market product, the keeping qualities and general appearance of which is desired to be first-class, should be grown without an application of Potash. Ask for prices.

\section{NITRATE OF SODA.}

Nitrate of Soda is not a substitute for other manures, but we recommend it as the cheapest and best form in which to apply Nitrogen to plants. Price (subject to market changes), 1b., 15c; 5 lbs., $65 \mathrm{c} ; 1$ lb., $\$ 1.15 ; 25$ lbs., $\$ 2.50$.

\section{SHEEP MANURE.}

For Lawns.-Pulverized Sheep Manure is the best possible for the lawn. It should be applied by sprinkling lightly over the grass, same as one would sow grass seed. It requires no raking in. The color is not conspicuous and there is no objectionable odor.

For the Garden.-After the crop has been harvested in the fall, the garden should be given a good coating of Sheep Manure. In the spring put on another light coat and turn it under, or sow lightly in the rows.

For Truck Garden.-Sheep Manure is the best fertllizer for the truck garden, producing better and earlier crops of onions, celery and nther vegetables.

For Public Parks. - Sheep Manure is used on some of the best public parks in this cnuntry, including the beautiful park system of Kansas City.

For Flower Beds.- Free blossoming can be Induced, or increased, by judiclous use of Sheep Manure. Sprinkle it carefully in the beds, and both follage and blossoms will be large and vivid in color. A teaspoonful or so stirred in the soil about the roots of each plant two or three times during the season will give you astonlshing results. 
VEGETAELE SEEDS.

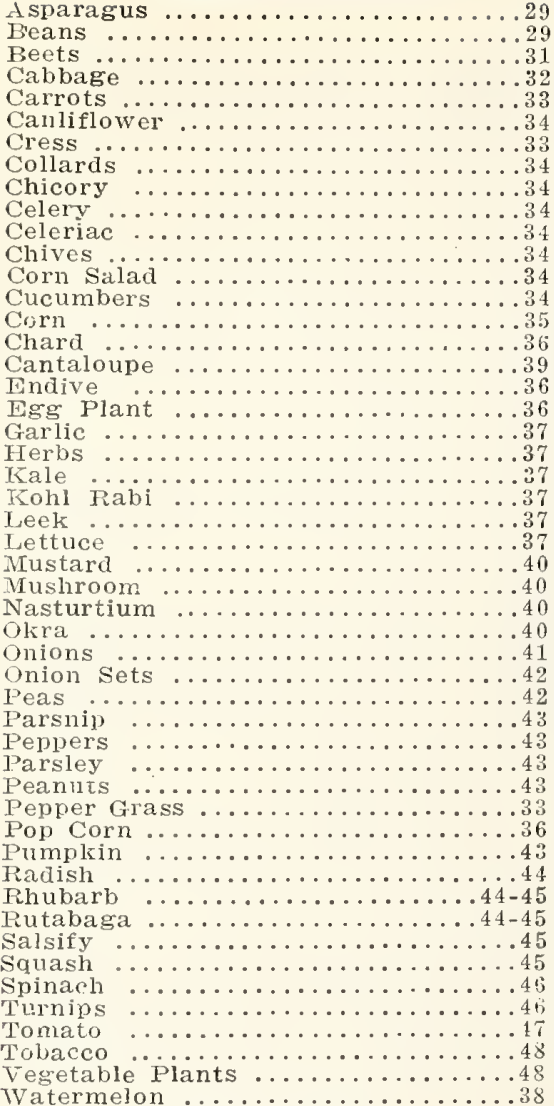

FIELD SEEDS.

Alfalfa

Corn .....

Cow Peas

English Bilue Grass

Feterita $\ldots . . . . .$.

Kaffir Corn

Lawn Grass

Milo Mäize

oat

Orchard Grass

Red Top ...........

Soy or soja Beans

Sunflower

Sudan Gras

Vetch

FLOWER SEEDS.

AYRES CELOSIA

All Varieties

Asters

Acrolinum

Aquilegis

Alyssum

Amaranthus

Arctotis Granđis

Balsam

Bolloon vine

Brachycome.

Calendula.

Calliopsis.

Campanula
Candytuft

Carnation.

Celosia.

Celosiamum.

Chrysanthemum.

Centaurca.

Cornflower.

Chinense Lantern Plant

Clarkia.

Coroca scandens

Columbin

Coreopsi

Cosmos.

Cypress Vine

Delphinium.

Daisy.

Jianthus.

Fischscholtzia.

Euphorbia.

Forset-Me-Nöt.

Four o'Clock

Gaillardia.

Geranium

Gomphrena.

Gourds.

Gypsophila.

Helianthus.

Helichrysum.

Hollyhock.

Hyacintl Bean

Kochia.

Larkspur

Linaria.

Linum

Lobelia.

Tunnemannia.

Marigold.

Mignonett

Lorning Glory

Nasturtium.

Nicotiana.

Nig"ella.

Pansy.

Petuni

Physalis.

Poppies.

Portulaca.

Salpigiossis.

Stoclis.

Straw Flowers

Sun Flower

Sweet Williain

Verbena.

lower.

SVVEET PEAS.

Cultural Directions

Alnaryllis.

SUMMER inuribs.

Caladium

Cinnamon vine

Funlia.

Gladioli.

Hemerocallis.

Hardy Tilies

Lily of the Valley.

Tiger Lily

Maderia Vine

Tube Rose

\section{DAHLIA}

\section{All Varieties ..................}

Ornamental Flowering Shrubs.

Table.

Althea.

Bimond

Barbelry. Busli

Currant.

Crab.

Calycanthus.

Deutzia.

Desmodium.

Elcagnus.

Elder.

Forsythia

Fringe.

Honeysuckle.

Horse Chestiut

Hydrangea.

Lilac.

Locust.

Plum.

Privet.

pea 'Tree

Snowball

Snowkerry.

Spirea.

Sumac.

Tamarix.

Weigela.

\section{Flowering shrubs.}

Hybrid Tea Roses

rosis:

Hybrid Perpetual Roses.........................

Novelty Roses

Hardy Climbing Roses................

Table. HARDY PEREN NIALS.

Shady Place Perennials..............17

Hot and Dry Place Perennials.....17

Aclilea. ..........................

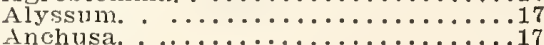

Anch

Anemone.
Aquilegia.

Aster.

Barbatus,

Bocconia.

Caropanula.

Carnation.

Ccritourea.

Cerastium.

Chinesis.

Chrysanthemum ................

Convallaria. . ........................

Jianthus.

Plumaris.

Delphinum.

Formosum.

Flava.

Gaillardia.

Gypsophila.

Helenium.

Helianthu

Henterocallis.

Heuchea,

Hollylock.

Hibiscus.

Thers.

Lavendula.

bilies.

Peonies.

Phlox.

Papaver.

Polygonum.

Primula.

Polyantha.

Pyrethrum.

Rudbeckia.

Sanguinea.

Sweet iviniam

Tritonia.

Vinca.

Violets.

Six Leading Perennials.

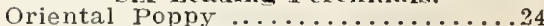

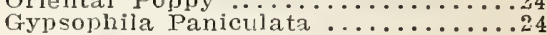

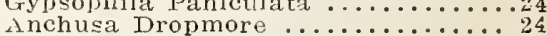

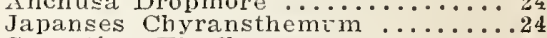
Carnation Fireflame ..............24 Celosia Chyrsanthemum .............. Eulalia. THADY GRASSES. Clamíg vines a Bittersweet.

Boston Ivy

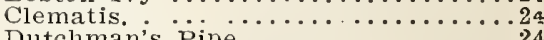

Englemann's Ivy $\ldots \ldots \ldots \ldots \ldots \ldots \ldots \ldots \ldots$

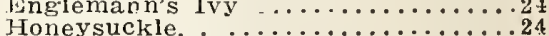

Triumpet Vine $\ldots \ldots \ldots \ldots \ldots \ldots \ldots \ldots \ldots . . \ldots \ldots$

Virsinia Creeper $\ldots \ldots \ldots \ldots \ldots \ldots \ldots \ldots .24$

$\ldots \ldots \ldots \ldots \ldots \ldots \ldots \ldots \ldots$

GVERGIRENS.

F.vergreens, ${ }_{\text {Vines }} \ldots \ldots \ldots \ldots \ldots \ldots 26$

Evergreen vines $\ldots \ldots \ldots \ldots 26$

SHADE IRTES.

.27

FRUIT TREES.

Apples
Apriccts. $\quad \ldots \ldots \ldots \ldots \ldots \ldots \ldots \ldots \ldots \ldots \ldots \ldots \ldots \ldots \ldots$

$\ldots \ldots \ldots \ldots \ldots \ldots$

Crab Apples $\ldots \ldots \ldots \ldots \ldots \ldots \ldots \ldots \ldots \ldots \ldots 7$

Peaches . ..............

Plums.

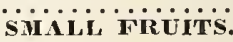

Asparagus. . ............... n2

Blackberries. . . . . . . . . .

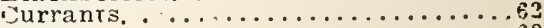

Grapes.

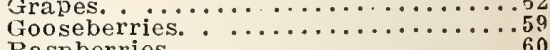

Raspberries. . ..............60

Rhubarb. .

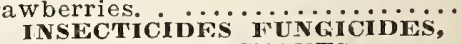
DISINFECTANTS.

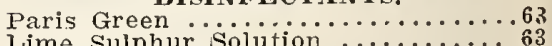

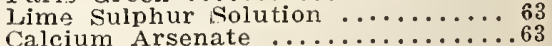

Bordeaux Mixture ............63

Arsenate of Lead ............63

Sure roxem

FERTiLizers.

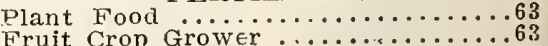

Fruit Crop Grower $\ldots \ldots \ldots \ldots \ldots \ldots \ldots 63$

Grain Grower .............63

Corn Grower $\ldots \ldots \ldots \ldots \ldots \ldots \ldots \ldots 6 . \ldots \ldots$

Sheep Manure $\ldots \ldots \ldots \ldots \ldots \ldots \ldots \ldots \ldots 6$

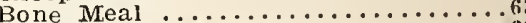

Ammonia or Nitrogen $\ldots \ldots \ldots \ldots .63$

Phosphoric Acid .............63

Potash $\ldots \ldots \ldots \ldots \ldots \ldots \ldots \ldots \ldots . \ldots \ldots 3$ 


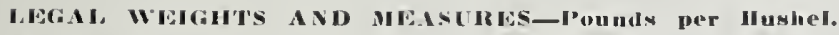

\section{AIITICIS:}

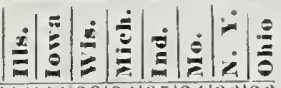

Apples, dried

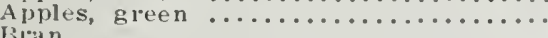

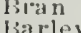

Beans. white

livans, Castor

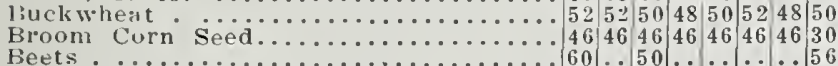

carrot.

Charcoal

Coal. stone

Coke shelled

Corn, ear

Corn, ear

Cranherries

Dried Feach
Flax Seed

Grass Seed, ßjue

Grass Seed, Clover

Grass Seed, Hungarian

Grass Seed. Mlillet..

Grass Seed. Orchard.

Grass Seed, Timothy

German I.upine

Hemp Seed

Hickory Nuts

Malt, Barley

Middlings, fin

Middlings, coars

Oats

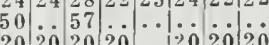
$20202020 \ldots 1202020$ \begin{tabular}{l|l|l|l|l|l|l|l}
48 & 48 & 48 & 45 & $4 S$ & 48 & $4 S$ & 48 \\
6 & 60 & 60 & 60 & 60 & 60 & 62 & 60
\end{tabular}

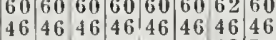
\begin{tabular}{l|l|l|l|l|l|l|l}
52 & 5 & 5 & 48 & 50 & 52 & 48 & 50 \\
46 & 46 & 46 & 46 & 46 & 46 & 46 & 30 \\
\hline & & 5 &
\end{tabular}

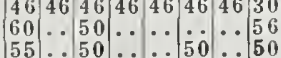
$\left.222222|2222|_{8}^{2} 22\right|_{30}$ 80

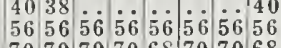

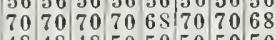
4848485050505050

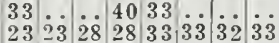
\begin{tabular}{lllllllll|l}
23 & -3 & 28 & 28 & 33 & 33 & 32 & 33 \\
56 & 56 & 56 & 56 & 56 & 56 & 56 & 56
\end{tabular} \begin{tabular}{lllllll|l|l|l}
14 & 14 & 14 & 14 & 14 & 14 & 15 & 10
\end{tabular}

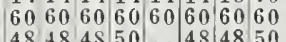
$\begin{array}{lllllll}48 & 48 & 48 & 50 & & 48 \mid 48 & 50 \\ 50 & 48 & 50 & 50 & 50 & 50 \mid & 50\end{array}$

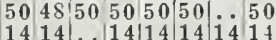

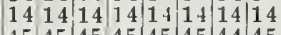
\begin{tabular}{ll|l|ll|l|l|l|l|l}
45 & 45 & 45 & 45 & 45 & 45 & 44 & 45
\end{tabular}

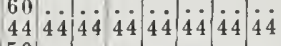

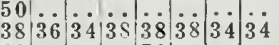

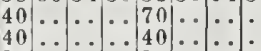
40
301
39

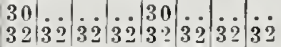

Onions
Onions, tops $\ldots \ldots \ldots \ldots \ldots \ldots \ldots \ldots \ldots \ldots \ldots \ldots \ldots$
On Onions, tops

Osage orange

I'arsnips.

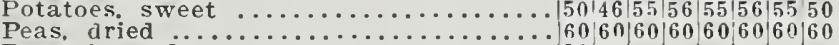

Peas. in pod.

Popcorn
Quicklime

Rye . ....

Salt, fine

33

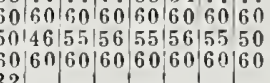

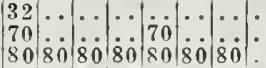

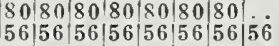
$50150150|50| 5015015050$ 55
$50 \mid 56$

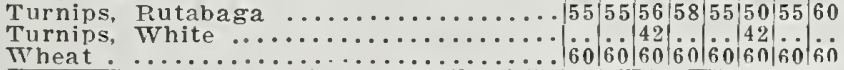

Dry Measure. 2 pints, 1 quart; 8 quarts, 1 peck; 4 pecks, 1 bushel: 36 bushels, 1 chaldron.

Liquid Measure. 4 gills, 1 pint; 2 pints, 1 quart; 4 quarts,

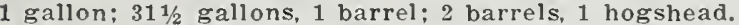

Ieasurements of an Aere. The following will be found useful in arriving at accuracy in estimating the amount of land in different pieces of ground under cultivation: 5 yards wide by 968 yards long, contains one acre, as do also the following measurements: 10 yards wide by 484 yards long: 20 yards wide by 242 yards long: 40 yards wide by 121 yards long: 70 yards wide by $691 / 2$ yards long: 60 feet wide by 726 feet long; 110 feet wide by 396 fcet long; 120 feet wide by 363 feet long; 220 feet wide by 198 feet long: 240 feet wide by $181 \frac{1 / 2}{2}$ feet long, and 440 feet wide by 99 feet long.

Number of PIants or Trees to the Aere at Given Distances.

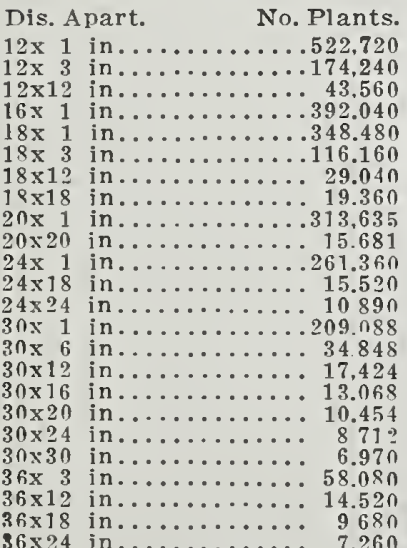

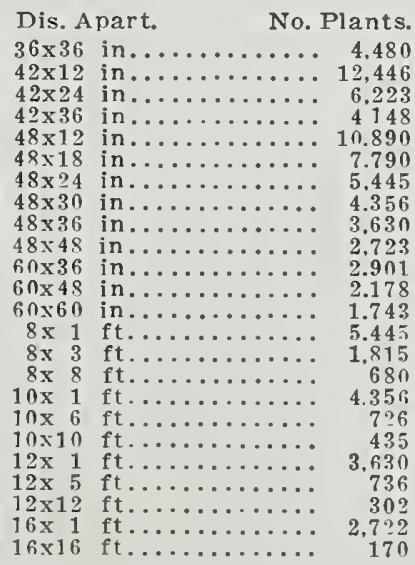

REFEIRNCE TAMIES.

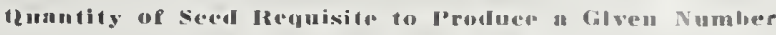

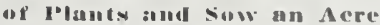

Artichokes. 1 oz. to 500 plants.

Asparagus, $10 z$. to 800 plants.

Asparagus Roots

Beans, Dwari, $i$ pint to $100 \mathrm{ft}$ of drili.

Beans, pole, 1 pint to 100 hills. Beet, garden, $1 \mathrm{oz}$. to $100 \mathrm{ft}$. of dirili Beet, mangel, 1 oz. to $100 \mathrm{ft}$ of drill. lirussels sprouts, 1 oz. to 5,000 plants. buckwheat

Cabbage, 1 oz. to 3,000 plants.

Carrut, $1 / 4$ oz. to $100 \mathrm{ft}$. of drill.

Cauliflower, 1 oz. to 3,000 plant
Celery, 1 oz. to 15,000 plants...

Chicory Clover. Alsike and Wönite Dutch.

Clover. Alsike and White Dutch.
Clover, Lucerne

Clover, Crimsun Trefoil

Clover, Large Red and Medium

Collaris. 1 oz. to 5.000

Corn, rice (shelled)

Corn, sweet, $1 / 4$ pint to 100 hills.

Cress. $3 / 4$ oz. to 100 feet of drill

Egg Plant. 1 oz. to 2.000 plants

Endive. $1 / 4$ oz. to $100 \mathrm{ft}$. of d d ill

Flax, broarlcast $\ldots$ bulbs, 1 in to in of drili.

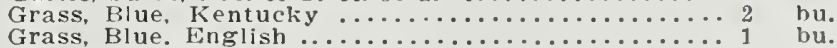

Grass, Hungarian and ililet

Grass, Mixed Lawn

Grass, Red Top. Fancy, Clean

Grass, Red Top, Chaff Seed..

Grass, Timothy

Quantity per Acre.

. 20 to 28 lbs.

Hemp

$$
\text { vood Meadow }
$$

Horseradish Rioot

Kale, 1 oz. to 5.000 plants.

Leek, $1 / 3$ oz to 100 ft of drill.

Lettuce, $1 / 4$ oz. to $100 \mathrm{ft}$. of $\mathrm{dril}$

Martynia. $1 \mathrm{nz}$. to $10 n \mathrm{ft}$. of drill.

Melon, Musk, 1 oz. to 100 hills.

Melon, Water. 4 oz. to 100 hills...

Nasturtium. $2 \mathrm{nz}$. to $100 \mathrm{ft}$. of drill

Onion Seed. $1 / 3$ oz. to $100 \mathrm{ft}$. of drili.

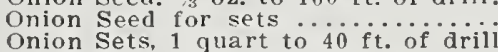

Onion Sets, 1 quart to $40 \mathrm{ft}$. of dril
Parsnip, $1 / 4$ oz. to $100 \mathrm{ft}$. of $\mathrm{drill} .$.

Parsley, $1 / 4$ oz. to $100 \mathrm{ft}$ of drill. 3 .

Peas, garrlen.
Peas, field

Pepper, 1 oz. to 1.500 plant

Pumpkins, $1 / 3$ quart to 10 hills.

Rve ....................

Spinach, $1 / 2$ oz. to $100 \mathrm{ft}$. of drili.

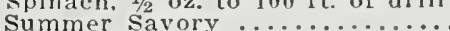

Sunflower

Squash. Summer, 4 oz. to 1 ino hills

Squash, Winter. 8 nz. to 10 h hills

Tomato, $1 \mathrm{oz}$. to 4.50 n plants.
Tobacco. $1 \mathrm{oz}$. to 5,000 plants.

Turnip. 1 oz. to $250 \mathrm{ft}$. of drill.

Vetches

Average Time Required for Garden Seels to Germinate.

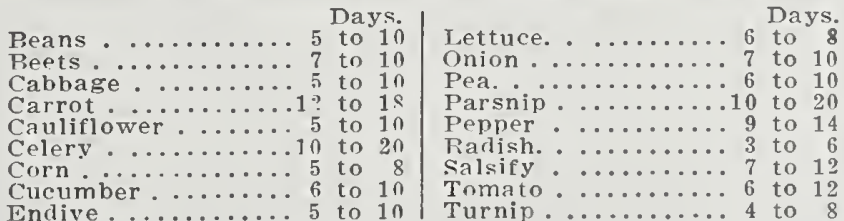

Time Required fur Maurity of Different Garden Crops Reckoned from the Iny of Sowing the seed.

Reans, String.....45 Days: Melon, Musk .....12n to 140

Beans, Shell.......65 to $7 n$ Melon, Water.....

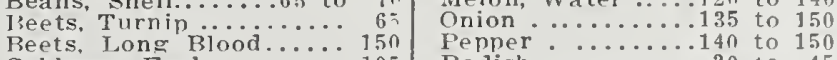

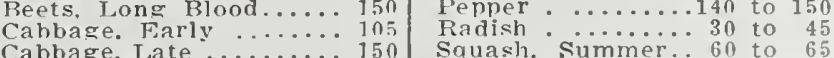

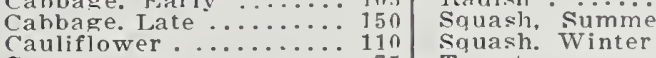

Corn

$11 \frac{0}{75}$

Exquiant . . . 150 to 160

Tomato

Turnip 


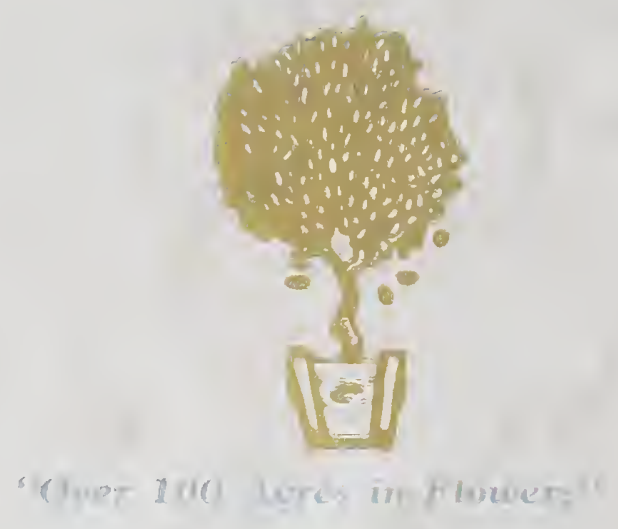

